\title{
ЕМКЕМЕСЯЧНЫЙ НАУЧНО-ТЕХНИЧЕСКИЙ
} И ПРОИЗВОДСТВЕННО-ЭКОНОМИЧЕСКИЙ МКУРНА
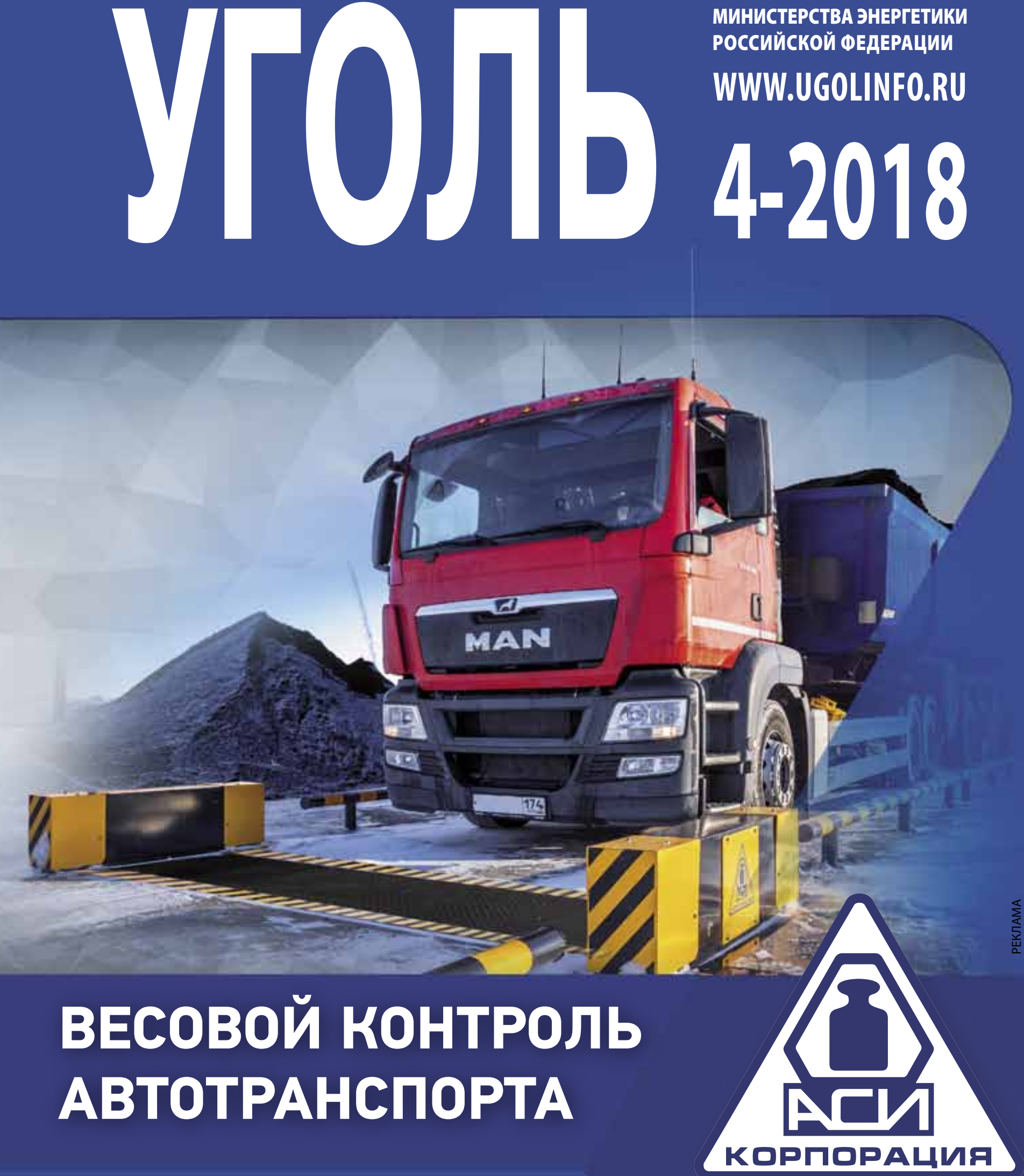

г. Кемерово, 650000, ул. Кузбасская, 31

e-mail: office@icasi.ru тел./факс: (384-2) 36-61-49, 36-55-01

г. Москва, ул. Малая Черкизовская, 22

WWW.ICASI.RU 


\section{ЕДИНОЕ РЕШЕНИЕ: ПРОБЛЕМЫ СМЕРЗАНИЯ УГЛЯ; БОРЬБА С ПЫЛЕНИЕМ УГЛЯ}

стр. $43-44$

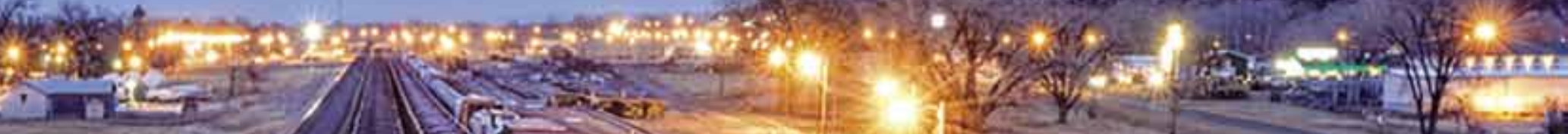
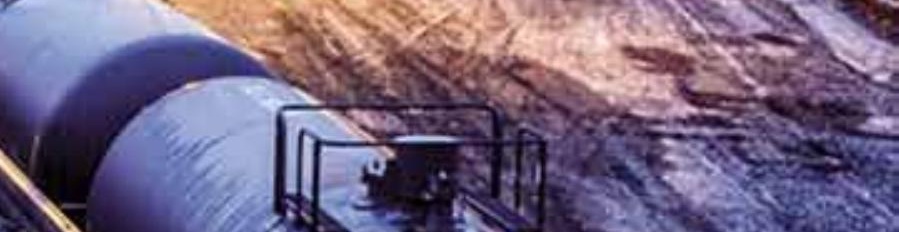

s.

t.
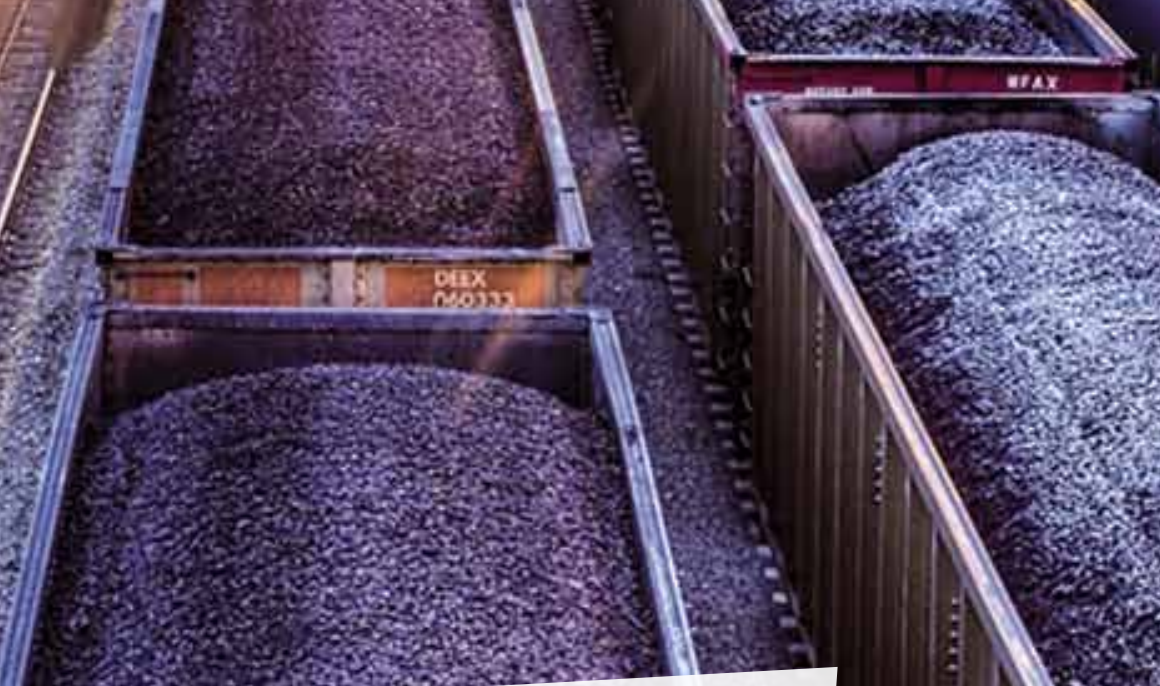

\section{(CLikayctulk}

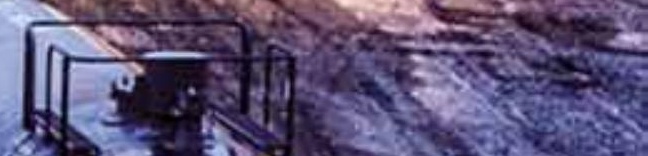

400097, Волгоград, ул. 40 лет ВЛКСМ, д. 57,

тел.: (8442) 40-61-02; 40-69-45

www.kaustik.ru

e-mail: bishofit@kaustik.ru 
СИСТЕМА БЕСПРОВОДНОЙ СВЯЗИ И ПОЗИЦИОНИРОВАНИЯ ПЕРСОНАЛА

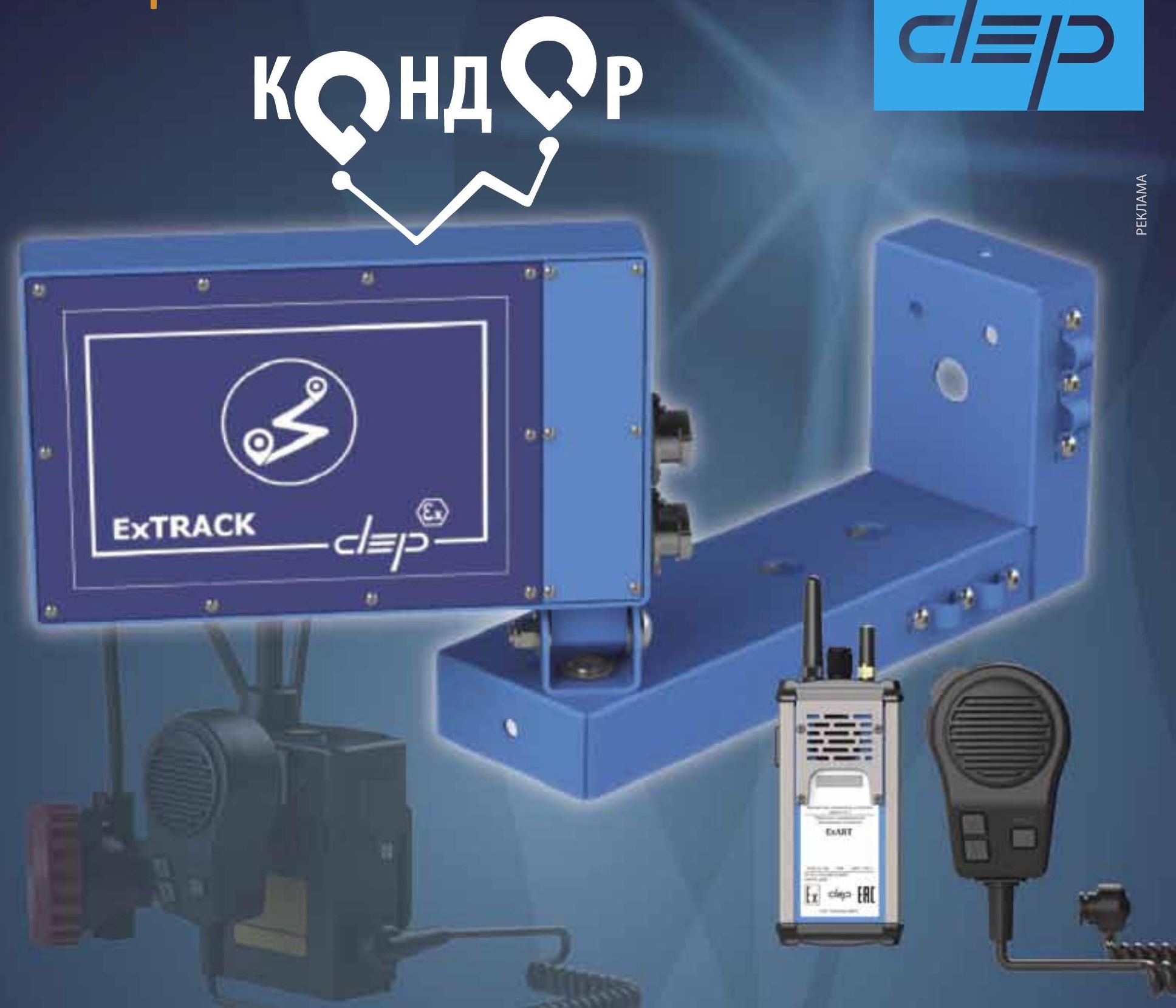

> Наблюдение и определение местоположения персонала в подземных выработках.

> Аварийное оповещение персонала независимо от его местоположения.

> Поиск и обнаружение людей застигнутых аварией.

> Подземная связь - оперативная, технологическая и аварийная.

$>$ Видеонаблюдение за персонала и технологическими объектами.

117545, г.Москва, ул. Подольских Курсантов, А.3,стр.8 тел/факс 995-00-12 • E-mail: mail@dep.ru www.dep.ru

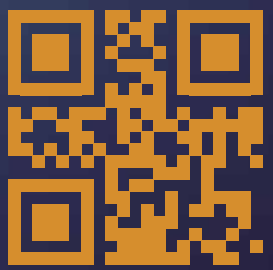




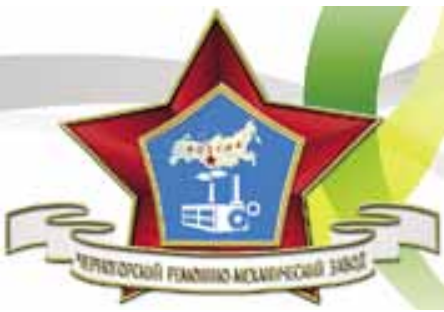

\section{ЧЕРНОГОРСКИЙ PM3}

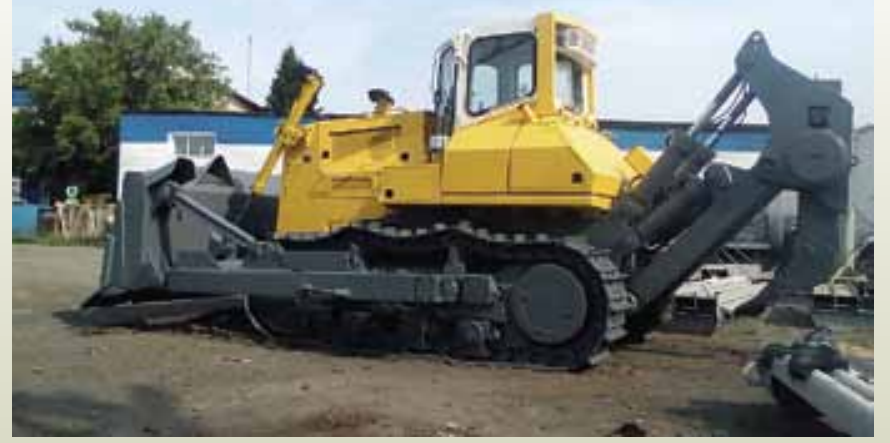

- Капитальный ремонт карьерной техники

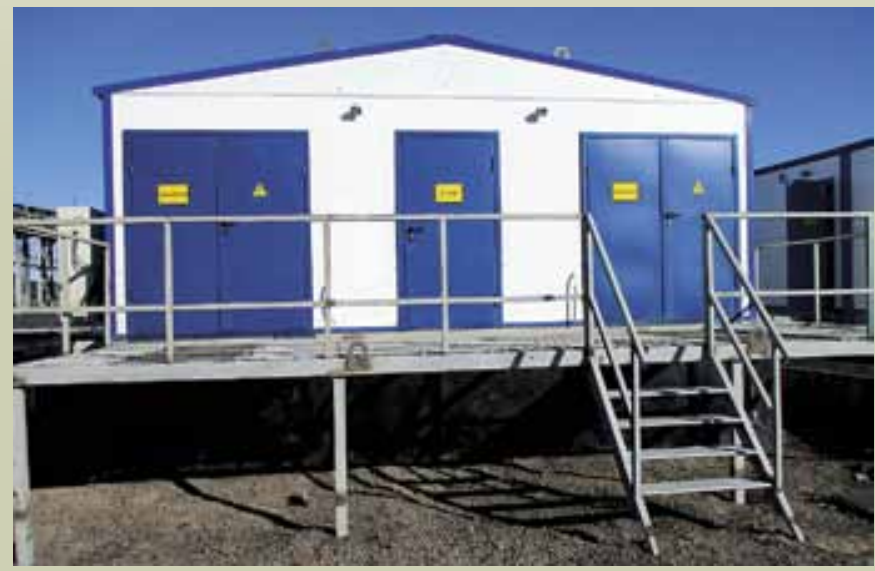

- Изготовление подстанций КТНН

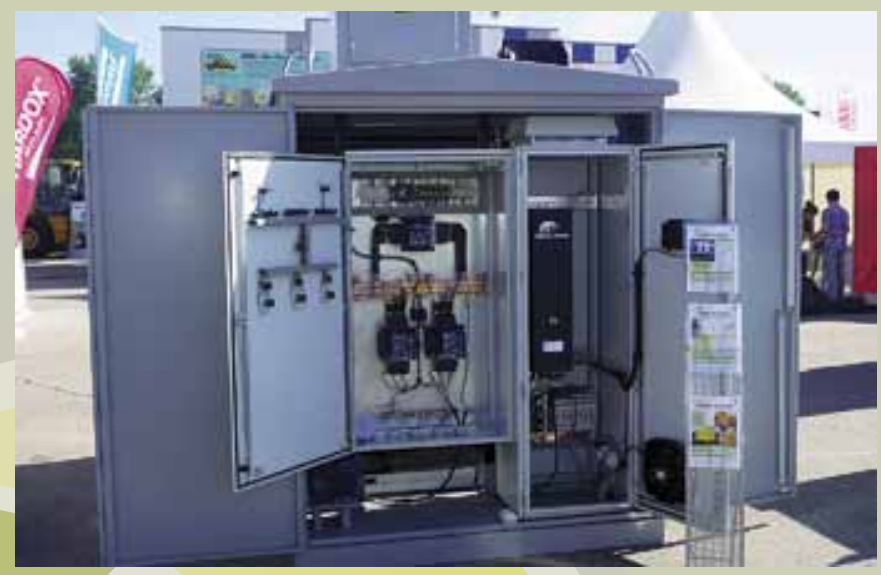

АО «Черногорский РМЗ»

655162, Республика Хакасия,

г. Черногорск, ул. Советская, 26

Тел./факс: +7 (39031) 5-53-01

Моб.: 8 (961) 898-75-14

E-mail: priemnaya_rmz@suek.ru

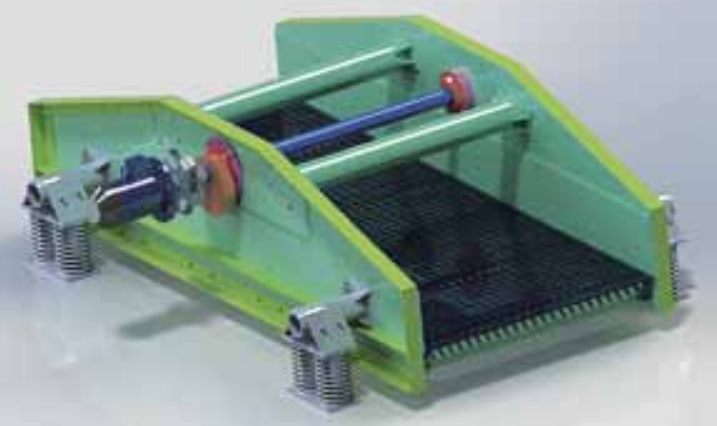

- Изготовление грохотов

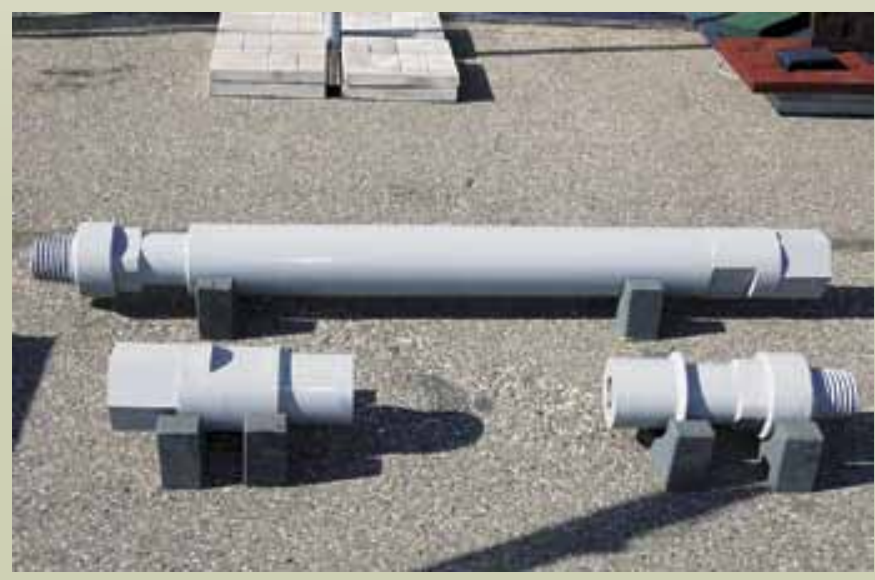

- Изготовление буровых штанг

АО «Черногорский РМЗ» - Российский ремонтномеханический завод оказывает полный спектр услуг по: ремонту горно-обогатительного и горнотранспортного оборудования, изготовлению навесного оборудования и запасных частей, изготовлению комплектных трансформаторных подстанций и буровых штанг для буровых станков открытой разработки.

АО «Черногорский РМЗ» является дочерним предприятием крупнейшей угольной компании России $\mathrm{AO}$ «СУЭК», одной из ведущих угольных компаний мира.

Специалисты AO «Черногорский РМЗ» готовы предложить эффективные инженерные решения и оказать профессиональную помощь при возникновении проблем, связанных с эксплуатацией горно-обогатительного и горнотранспортного оборудования.

Квалифицированный персонал обеспечит техническое обслуживание и постгарантийный ремонт оборудования. 
Главный редактор

ЯНОВСКИЙ А.Б.

Заместитель министра энергетики

Российской Федерачии,

доктор экон. наук

\section{Зам. главного редактора}

ТАРАЗАНОВ И.Г.

Генеральный директор

ООО «Редакция журнала «Уголь»,

горный инженер, чл.-корр. РАЭ

\section{РЕДАКЦИОННАЯ КОЛЛЕГИЯ}

АРТЕМЬЕВ В.Б, Әоктор теХн. Наук

ВЕРЖАНСКИЙ А.П.,

доктор техн. наук, профессор

ГАЛКИН В.А., доктор техн. наук, профессор

ЗАЙДЕНВАРГ В.Е.,

доктор техн. наук, профессор

ЗАХАРОВ В.Н., ЧЛ.-КОрр. РАН,

Әоктор техн. Наук, профессор

КОВАЛЬЧУК А.Б.,

доктор техн. наук, профессор

ЛИТВИНЕНКО В.С.,

доктор техн. наук, профессор

МАЛЫШЕВ Ю.Н., академИК РАН,

доктор техн. наук, профессор

МОХНАЧУК И.И., КаНд. эКОН. НаУК

МОЧАЛЬНИКОВ С.В., Канд. эКОН. наук

ПЕТРОВ И.В., доктор экон. наук, профессор

попОВ В.Н., доктор экон. наук, профессор

ПОТАПОВ В.П.,

доктор техн. наук, профессор

ПучкОВ л.А., чл.-корр. РАН,

доктор техн. наук, профессор

РОЖкОВ А.А., доктор экон. наук, профессор

РЫБАК Л.В., доктор экон. наук, профессор

СКРЫЛЬ А.И., горный инженер

СУСЛОВ В.И., чл.-корр. РАН, доктор экон.

наук, профессор

ЩАДОВ В.М., доктор техн. наук, профессор ЩУКИН В.К., доктор экон. наук

ЯКОВЛЕВ Д.В., доктор техн. наук, профессор

\section{Иностранные члены редколлегии}

Проф. Гюнтер АПЕЛЬ,

доктор техн. наук, Германия

Проф. Карстен ДРЕБЕНШТЕДТ,

доктор техн. наук, Германия

Проф. Юзеф дУБИНьСКИ,

доктор техн. наук, чл.-корр. Польской

академии наук, Польша

Сергей НИКИШИЧЕВ, комп. лицо FIMMM,

канд. экон. наук, Великобритания, Россия,

страны СНГ

Проф. Любен ТОТЕВ,

доктор наук, Болгария

\section{ЕЖЕМЕСЯЧНЫЙ \\ НАУЧНО-ТЕХНИЧЕСКИЙ И ПРОИЗВОДСТВЕННО-ЭКОНОМИЧЕСКИЙ ЖУРНАЛ}

Основан в октябре 1925 года

\section{УЧРЕДИТЕЛИ}

МИНИСТЕРСТВО ЭНЕРГЕТИКИ

РОССИЙСКОЙ ФЕДЕРАЦИИ

РЕДАКЦИЯ ЖУРНАЛА «УГОЛЬ»

АПРЕЛЬ

$4-2018 / 1105 /$

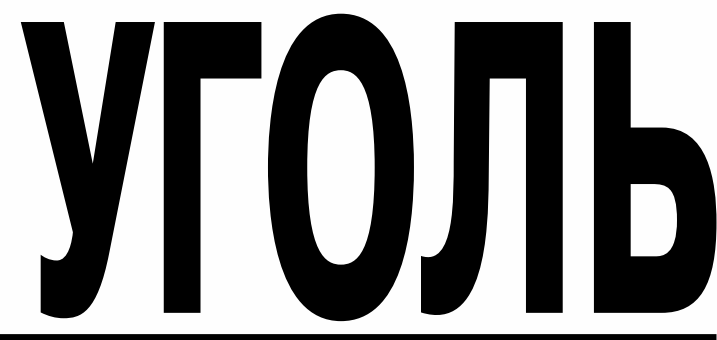

\section{ВЫПУСК ПРИУРОЧЕН: \\ XXV Международной \\ специализированной выставке \\ «УГОЛЬ РОССИИ И МАЙНИНГ»}

(05 - 08.06.2018 г., Новокузнецк)

\section{УГОЛЬ РОССИИ И МАЙНИНГ}

\section{5 лет вместе!}

Международные специализированные выставки: «Уголь России и Майнинг»,

«0храна, безопасность труда и жизнедеятельности», «Недра России»

\section{ОТКРЫТЫЕ РАБОТЫ}

Добровольский А.И., Шевкун Е.Б., Лещинский А.В., Галимьянов А.А.

Механизация забойки взрывных скважин при отработке наклонных

угольных пластов сложного строения

\section{ОРГАНИЗАЦИЯ ПРОИЗВОДСТВА}

Рыбак Л.В., Рыбак В.Л., Алексеев Г.Ф., Бурцев С.В., Перекрестова М.Г., Макаров Ю.В., Киселев А.С.

Холдинговая компания «СДС-Уголь»: международные подходы в области менеджмента качества,

экологии и охраны труда

\section{ИННОВАцИИ}

Ефимов В.И., Корчагина Т.В., Колычев А.С., Митичкин С.И.

Пути решения инновационных задач в угольной промышленности

\section{БЕЗОПАСНОСТЬ}

Бурцев С.В., Басыров 0.Ф.

Комплексный подход в области промышленной безопасности и охраны труда

Новоселов С.В., Панихидников С.А.

Основной путь ликвидации взрывов метана в высоконагруженных очистных забоях угольных шахт опасных по газу - предупреждение создания взрывоопасной метановоздушной смеси _ 31

XI Международные горноспасательные соревнования IMRC-2018

\section{ВОПРОСЫ КАДРОВ}

Холодов П.П., Юнгблюдт С.В., Ботвенко Л.А.

Совершенствование методологии повышения квалификации руководителей и специалистов особо опасных производств ТЭКа как способ решения проблем безопасности

\section{TPAHСПОРТ}

А० «КАУСТИК»

Пыление и смерзание угля: проблемы и решения

MAN определяет дальнейшее развитие в России 46

Корпорация «АСИ»

Весовой контроль автотранспорта

$\mathrm{A} 0$ «ГПФК»

Профессиональная линейка смазочных материалов и специальных жидкостей для техники БЕЛАЗ

\section{НЕДРА}

Бесимбаева 0.Г., Хмырова Е.Н., Оленюк С.П., Олейникова Е.А., Старостина 0.В.

Обоснование расчетных прочностных характеристик горных пород

баритового месторождения

Коваленко В.С.

Повышение эффективности использования природных и техногенных ресурсов при открытой угледобыче в рамках концепции «зеленой» горнодобывающей промышленности 60 
ООО «РЕДАКЦИЯ ЖУРНАЛА «УГОЛЬ»

119049, г. Москва,

Ленинский проспект, д. 2А, офис 819

Тел.: +7 (499) 237-22-23

E-mail:ugol1925@mail.ru

E-mail:ugol@land.ru

Генеральный директор

Игорь ТАРАЗАНОВ

Ведущий редактор

Ольга ГЛИНИНА

Научный редактор

Ирина КОЛОБОВА

Менеджер

ИрИна ТАРАЗАНОВА

Ведущий специалист

Валентина ВОЛКОВА

ЖУРНАЛ ЗАРЕГИСТРИРОВАН

Федеральной службой по надзору

в сфере связи и массовых коммуникаций.

Свидетельство о регистрации

средства массовой информации

ПИ № ФС77-34734 от 25.12.2008

ЖУРНАЛ ВКЛЮЧЕН

В Перечень ВАК Минобразования и науки РФ

(в международные реферативные базы

данных и системы цитирования) -

по техническим и экономическим наукам

Пятилетний импакт-фактор РИНЦ

без самоцитирования - 0,315

ЖУРНАЛПРЕДСТАВЛЕН

в Интернете на вэб-сайте

\section{www.ugolinfo.ru www.ugol.info}

и на отраслевом портале

«РОССИЙСКИЙ УГОЛЬ»

www.rosugol.ru

информационный партнер журнала - УгОЛЬНЫЙ ПОРТАЛ

\section{www.coal.dp.ua}

НАД НОМЕРОМ РАБОТАЛИ:

Ведущий редактор О.И. ГЛИНИНА

Научный редактор И.М. КОЛОБОВА

Корректор В.В. ЛАСТОВ

Компюютерная верстка Н.И. БРАНДЕЛИС

Подписано в печать 04.04.2018.

Формат 60×90 1/8.

Бумага мелованная. Печать офсетная.

Усл. печ. л. 11,0 + обложка.

Тираж 4700 экз.

Тиражэл. версии 1600 экз.

Общий тираж 6500 экз.

Отпечатано:

ООО «РОЛИКС

117218, г. Москва, ул. Кржижановского, 31

Тел.: (495) 661-46-22;

www.roliksprint.ru

Заказ № 48404

Журнал в App Store $и$ Google Play

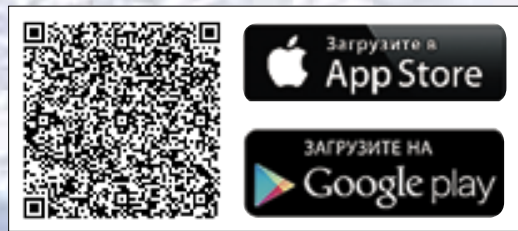

๑ ЖУРНАЛ «УГОЛЬ», 2018
ХРОНИКА

Хроника. События. Факты. Новости

ПЕРЕРАБОТКА УГЛЯ

Джованис Д.

Больше угля - больше денег

Антипенко Л.А.

Методы оценки обогатимости углей

\section{экология}

Харионовский А.А., ФранкЕ.Я.

Обоснование технологии горнотехнической рекультивации

в целях лесовосстановления на Крутокачинском щебеночном карьере

СТРАНИЦЫ ИСТОРИИ

Рожков А.А., Соловенко И.С., Марчук В.И., Суздалова М.А.

Всероссийские «рельсовые войны» шахтёров в мае 1998 года

К 100-летию со дня рождения профессора Благова Игоря Сильвестровича (1918 - 1987 гг.)

82

\section{ЗА РУБЕЖОМ}

Зеньков И.В.

Организация горного производства и управление логистикой

в угледобывающем секторе экономики Колумбии

\section{ЮБИЛЕИ}

Галкин Владимир Алексеевич (к 70-летию со дня рождения)

Экгардт Виктор Иванович (к 70-летию со дня рождения) 87

\section{ХРОНИКА}

Требования к рукописям, направляемым в журнал «УГоль»

Список реклам:

Корпорация «АСИ» 1-я обл. . . Выставка Уголь России и Майнинг

AO «КАУСТИК» 2-я обл.

ЛИБХЕРР-РУСЛАНД 3-я обл.

Карбокор

BELAZ G-Profi

6 НПФ Гранч

Компания ДЭП

Черногорский РМЗ

1 -

НПП Завод МДУ

МУФТА ПРО

WEIR Minerals 37 2 45 65

Журнал «Уголь» входит

в международные ресеративные базы данных и систем цитирования

\section{SCOPUS, GeoRef, Chemical Abstracts}

Журнал «Уголь» является партнером CROSSREF

Редакция журнала «Уголь» является членом Международной ассоциации по связям издателей / Publishers International Linking Association, Inc. (PILA).

Всем научным статьям журнала присваиваются Digital Object Identifier (DOI).

\section{Журнал «Уголь» является партнером EBSCO}

Редакция журнала "Уголь» имеет соглашение с компанией EBSCO Publishing, Inc. (США). Все публикации журнала «Уголь» с 2016г. входят в базуданных компании EBSCO Publishing (www.ebsco.com), предоставляющей свою базу данных для академических библиотек по всему миру. EBSCO имеет партнерские отношения с библиотеками на протяжении уже более 70 лет, обеспечивая содержание исследований качества, мощные технологии поиска и интуитивные платформы доставки.

\section{Журнал «Уголь» представлен в «КиберЛенинке»}

Электронная научная библиотека «КиберЛенинка» (CYBERLENINKA) входит в mon-10 мировых электронных хранилищ научных публикачий и построена на парадигме открытой науки (Open Science), основными задачами которой являются популяризация науки и научной деятельности, общественный контроль качества научных публикаций, развитие междисциплинарных исследований и повышение цитируемости российской науки. Это третья в мире электронная библиотека по степени видимости материалов в Google Scholar.

\section{Подписные индексы:}

- Каталог Роспечати «Газеты. Журналы» - 71000, 71736, 73422

- Объединенный каталог «Пресса России» - 87717, 87776, 987717

- Каталог «Почта России» - П3724

- Каталог «Российской прессы» - 11538

- Каталог «Урал-Пресс» - 71000; 007097; 009901 
UGOL' / RUSSIAN COAL JOURNAL

UGOL' JOURNAL EDITORIAL BOARD

Chief Editor

YANOVSKY A.B., Dr. (Economic), Ph.D.

(Engineering), Deputy Minister of Energy

of the Russian Federation, Moscow,

107996, Russian Federation

Deputy Chief Editor

TARAZANOV I.G., Mining Engineer, Moscow,

119049, Russian Federation

Members of the editorial council:

ARTEMIEV V.B., Dr. (Engineering),

Moscow, 115054, Russian Federation

VERZHANSKY A.P., Dr. (Engineering), Prof.,

Moscow, 125009, Russian Federation

GALKIN V.A., Dr. (Engineering), Prof.,

Chelyabinsk, 454048, Russian Federation

ZAIDENVARG V.E., Dr. (Engineering), Prof.,

Moscow, 119019, Russian Federation

ZAKHAROV V.N., Dr. (Engineering), Prof.,

Corresp. Member of the RAS,

Moscow, 111020, Russian Federation

KOVALCHUK A.B., Dr. (Engineering), Prof.,

Moscow, 119019, Russian Federation

LITVINENKO V.S., Dr. (Engineering), Prof.,

Saint Petersburg, 199106, Russian Federation

MALYSHEV Yu.N., Dr. (Engineering), Prof.,

Acad. of the RAS, Moscow, 125009, Russian

Federation

MOKHNACHUK I.I., Ph.D. (Economic),

Moscow, 109004, Russian Federation

MOCHALNIKOV S.V., Ph.D. (Economic),

Moscow, 107996, Russian Federation

PETROV I.V., Dr. (Economic), Prof.,

Moscow, 119071, Russian Federation

POPOV V.N., Dr. (Economic), Prof.,

Moscow, 119071, Russian Federation

POTAPOV V.P., Dr. (Engineering), Prof.,

Kemerovo, 650025, Russian Federation

PUCHKOV L.A., Dr. (Engineering), Prof.,

Corresp. Member of the RAS, Moscow, 119049 ,

Russian Federation

ROZHKOV A.A., Dr. (Economic), Prof.,

Moscow, 119071, Russian Federation

RYBAK L.V., Dr. (Economic), Prof.,

Moscow, 119034, Russian Federation

SKRYL' A.I., Mining Engineer,

Moscow, 119049, Russian Federation

SUSLOV V.I., Dr. (Economic), Prof., Corresp.

Member of the RAS, Novosibirsk, 630090, Russian

Federation

SHCHADOV V.M., Dr. (Engineering), Prof.,

Moscow, 119034, Russian Federation

SHCHUKIN V.K., Dr. (Economic),

Ekibastuz, 141209, Republic of Kazakhstan

YAKOVLEV D.V., Dr. (Engineering), Prof.,

Saint Petersburg, 199106, Russian Federation

Foreign members of the editorial council:

Prof. Guenther APEL, Dr.-Ing.,

Essen, 45307, Germany

Prof. Carsten DREBENSTEDT, Dr. (Engineering),

Freiberg, 09596, Germany

Prof. Jozef DUBINSKI, Dr. (Engineering), Corresp.

Member PAS, Katowice, 40-166, Poland

Sergey NIKISHICHEV, FIMMM, Ph.D. (Economic),

Moscow, 125047, Russian Federation

Prof. Luben TOTEV, Dr., Sofia, 1700, Bulgaria

Ugol' Journal Edition LLC

Leninsky Prospekt, 2A, office 819

Moscow, 119049, Russian Federation

Tel.: +7 (499) 237-2223

E-mail: ugol1925@mail.ru

www.ugolinfo.ru
MONTHLY JOURNAL, THAT DEALS WITH SCIENTIFIC, TECHNICAL, INDUSTRIAL AND ECONOMIC TOPICS

Established in October 1925

FOUNDERS

MINISTRY OF ENERGY

THE RUSSIAN FEDERATION,

UGOL' JOURNAL EDITION LLC

APRIL

$4^{\prime} 2018$

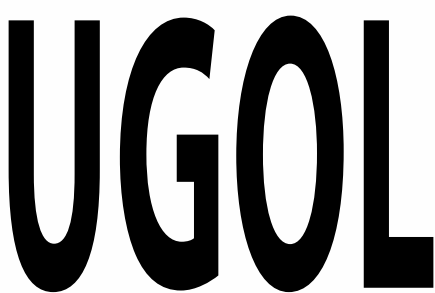

RUSSIAN COAL JOURNAL

\section{UGOL ROSSII \& MINING}

25 years together! International specialized exhibitions: "Ugol Rossii \& Mining",

"Health and Labor Safety", "Mineral Resources Russia”

SURFACE MINING

Dobrovolskiy A.I., Shevkun E.B., Leshchinsky A.V., Galimyanov A.A.

Tamping mechanization explosive wells at working off of inclined coal layers complex structure 10 PRODUCTION SETUP

Rybak L.V., Rybak V.L., Alekseev G.F., Burtsev S.V., Perekrestova M.G., Makarov Yu.V., Kiselev A.S.

"SBU-Coal" Holding Company: the international approaches in the field of quality management ecology and labor safety

INNOVATIONS

Efimov V.I., Korchagina T.V., Kolychev A.S., Mitichkin S.I.

Ways of solving innovative tasks in the coal industry 22

SAFETY

Burtsev S.V., Basyrov 0.Ph.

Integrated approach in the field of industrial safety and labour protection 26

Novoselov S.V., Panihidnikov S.A.

The primary pathway for elimination of methane explosions in highly longwall face of coal mines dangerous

on gas - hazardous minings is to prevent the creation of an explosive methane-air mixture

IMRC-2018: XI International Mines Rescue Competition Russia 36

CURRENT ISSUES

Kholodov P.P., Jungbludt S.V., Butvenko L.A.

Improving the methodology of training of managers and specialists particularly hazardous industries,

enterprises of Fuel and energy complex as a way of solving security problems

TRANSPORT

"KAUSTIK"JSC

Dusting and freezing of coal: problems and decisions

MAN defines further development in Russia

"ASI" Corporation

Weight estimate systems of truck

Professional line of lubricants and special liquids for the BELAZ

MINERALS RESOURCES

Besimbayeva 0.G., Khmyrova E.N., Olenyuk S.P., Oleynikova E.A., Starostina 0.V.

Validation of design strength characteristics of barite field rocks

Kovalenko V.S.

Increase in efficiency of natural and man-made resources use in open coal mining within

the framework of the concept of "green" mining industry

CHRONICLE

The Chronicle. Events. The Facts. News

COAL PREPARATION

David Geovanis

The more coal the more money

Antipenko L.A.

Methods of assessment of coal washability

ECOLOGY

Kharionovsky A.A., Frank E.Ya.

Validation of the technology of mine technical reclamation for the purpose of reforestation

in the Krutokachinskiy ballast quarry

CHAPTER IN HISTORY

Rozhkov A.A., Solovenko I.S., Marchuk V.I., Suzdalova M.A.

All-Russian "rail wars" of miners in May 1998

78

Blagov Igor Silvestrovich (1918 - 1987). To a 100-anniversary from birthday 82

ABROAD

Zenkov I.V.

Organizing mining practice and logistics management in Colombia's coal mining sector

84

ANNIVERSARIES

Galkin Vladimir Alekseyevich (to a 70-anniversary from birthday)

Ekgardt Victor Ivanovich (to a 70-anniversary from birthday) 87 


\section{mufi@}

XXV МежАународная специализированная выставка технологий горных разработок
5-8 июня 2018 Новокузнецк / Россия
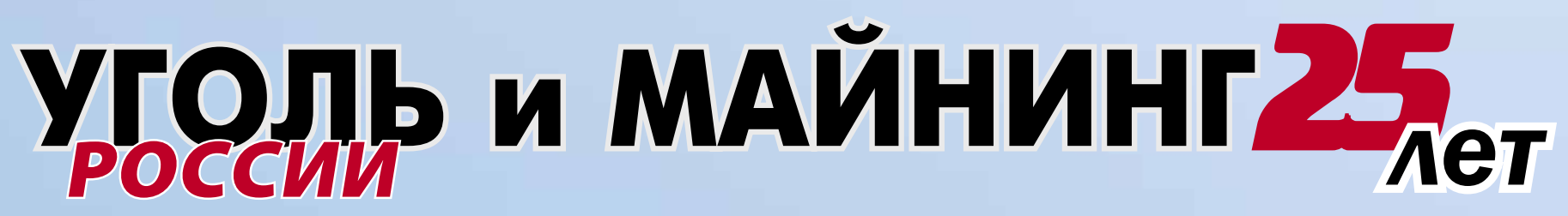

IX Международная специализированная выставка

\section{OХРАНА, БЕЗОПАСНОСТЬ ТРУАА И ЖИЗНЕАЕЯТЕАЬНОСТИ}

IV Международная специализированная выставка

\section{НЕАРА РОССИИ}

\section{Организаторы}
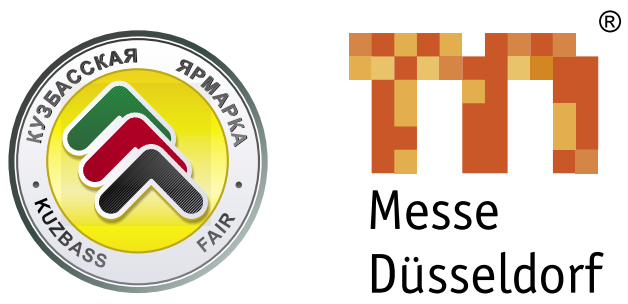

Messe

Düsseldorf
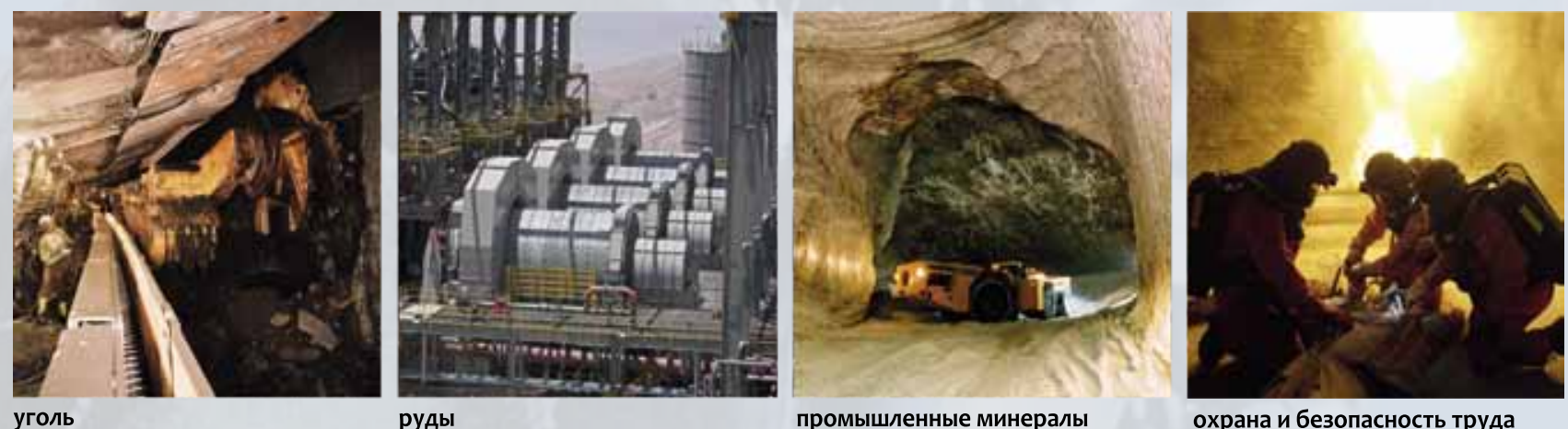

руды

промышленные минералы

охрана и безопасность труда

МЕСТО ПРОВЕДЕНИЯ:

Выставочный комплекс "Кузбасская ярмарка", ул. Автотранспортная, 51, г. Новокузнецк т./क: 8 (3843) 32-11-89, 32-22-22 e-mail: com@kuzbass-fair.ru 


\section{поступил проходческий комплекс SANDVIK MINING нового поколения}

На шахте «Талдинская-Западная - 2» АО «СУЭК-Кузбасс» ведется монтаж нового комбайна фронтального действия МВ 670-1. В состав проходческого комплекса SANDVIK MINING также входят самоходный вагон, бункер-перегружатель и дробилка.

Оборудование поступило в рамках инвестиционной программы Сибирской угольной энергетической компании, направленной на модернизацию и обновление техники, задействованной в подготовке очистного фронта.

Напомним, что в ноябре 2017 г. СУЭК приобрела восемь проходческих комбайнов фирмы SANDVIK MINING. Общая сумма инвестиций в данное шахтное оборудование составило более 27 млн евро.

Семь комбайнов предназначены для шахт компании «СУЭК-Кузбасс»: по два комбайна для шахт имени С.М. Кирова и «Талдинская-Западная - 2», три - для шахты имени В.Д. Ялевского. Всего же за последние три года объем инвестиций в компанию «СУЭК-Кузбасс» составил более 69 млрд руб.

Преимуществами проходческого комплекса Sandvik перед используемыми сегодня на шахте «Талдинская-Западная - 2» комбайнами избирательного действия КП-21, КП-220, П-110 являются его высокая производительность и безопасность выполнения всех видов работ. Главная особенность Sandvik MB 670-1 в том, что он способен одновременно производить выемку горной массы, крепление кровли и бортов выработок. Комплекс оснащен усовершенствованной системой пылеподавления, позволяющей значительно снизить уровень угольной пыли. Максимальная ширина резания нового комбайна составляет 5200 мм, высота резания - 3500-4500 мм. Общая масса - 95 т. Оборудование будет задействовано в проведении горных выработок по новому пласту, с которым связано развитие шахты.

В компании «СУЭК-Кузбасс» уже есть успешный опыт использования комплекса такого типа. В декабре 2016 г. бригада Героя Кузбасса Александра Куличенко шахты «Талдинская-Западная - 1» комбайном Sandvik MB-670 подготовила 1272 м горных выработок, обновив тем самым собственный отраслевой рекорд месячной проходки.

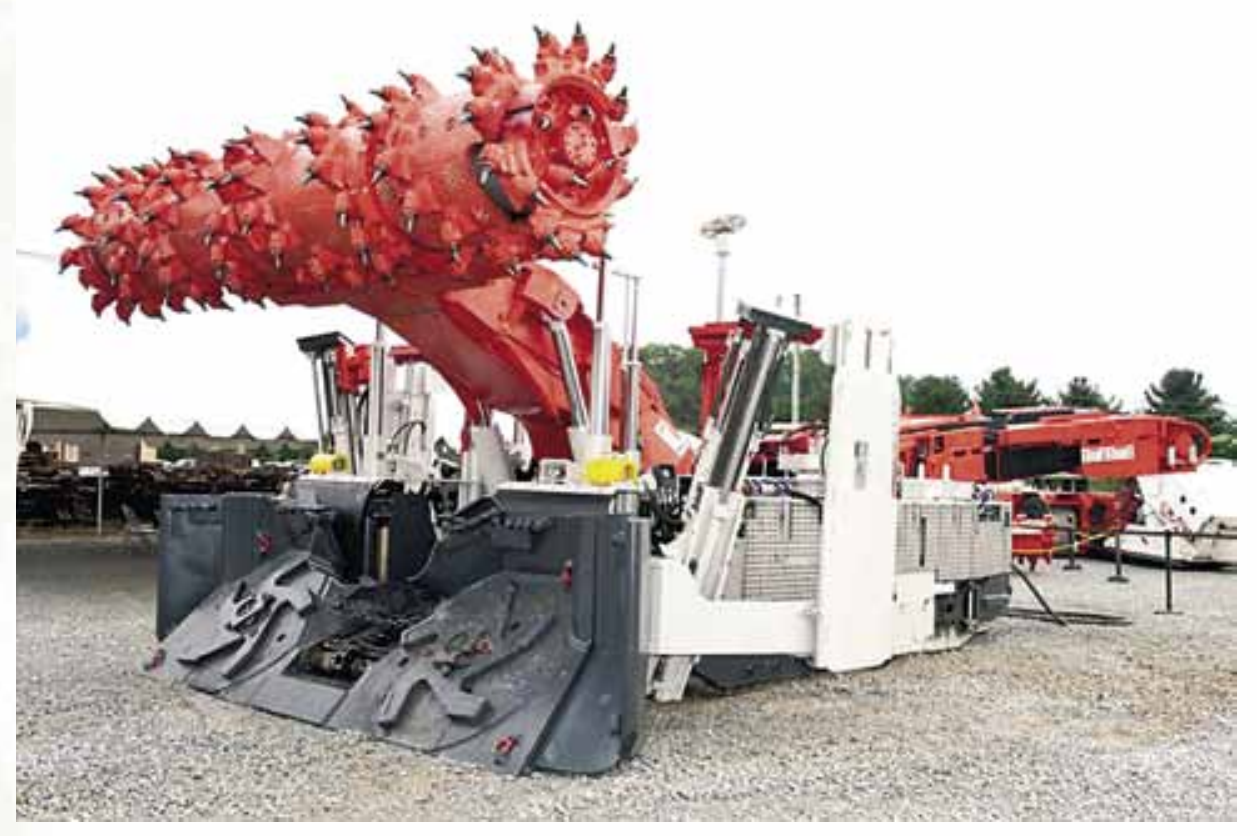




\section{HA ПЕРЕДНЕМ KPAE ДРОБЛЕНИЯ И СОРТИРОВКИ}

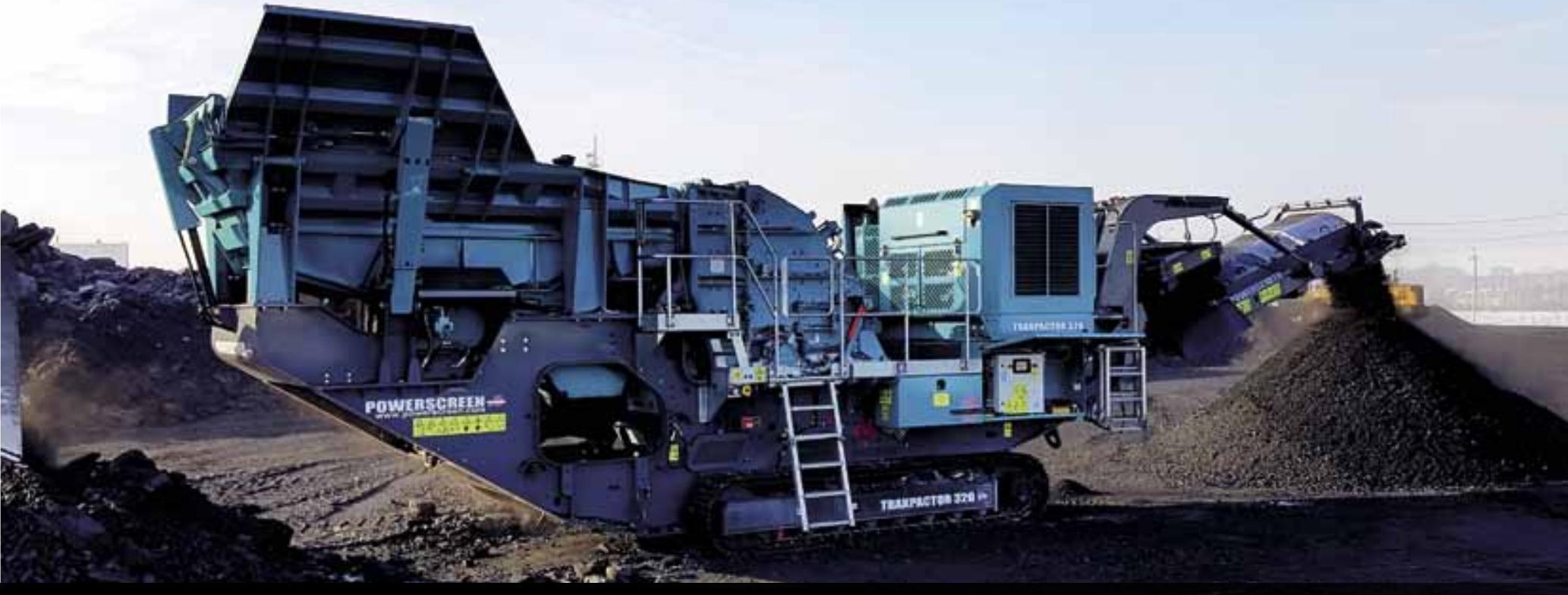

Наша цель - обеспечить потребителей современной техникой для карьеров, горнодобывающей, горно-обогатительной и горноперерабатывающей отраслей промышленности.

Опираясь на многолетний опыт сотрудничества с ведущими зарубежными и российскими предприятиями, мы можем предложить:

- инновационное оборудование для дробления, сортировки, промывки и обогащенния рудных и нерудных полезных ископаемых;

- оборудование для переработки твердых неорганических бытовых и промышленных отходов;

- оборудование для магнитной очистки материалов;

- разработку технологических схем, подбор и поставку оборудования;

- монтаж, пусконаладочные работы и обучение персонала заказчика;

- гарантийное, послегарантийное и сервисное обслуживание;

- поставку запасных частей и расходных материалов со склада в Кемерово;

- «горячую линию» информационной и консультационной поддержки;

- Предоставляем услуги по сортировке и дроблению материалов на складе заказчика.

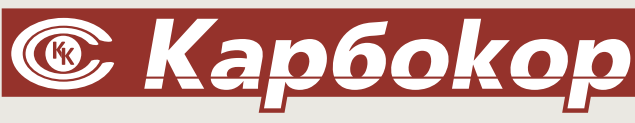

650000, РФ, г. Кемерово, ул. Мичурина 13, офис 207
Телефоны: (3842) 580777, 582293

Эл. почта: info@carbocor.ru

Сайт: $\quad$ www.carbocor.ru 


\section{Механизация забойки взрывных скважин при отработке наклонных угольных пластов сложного строения}
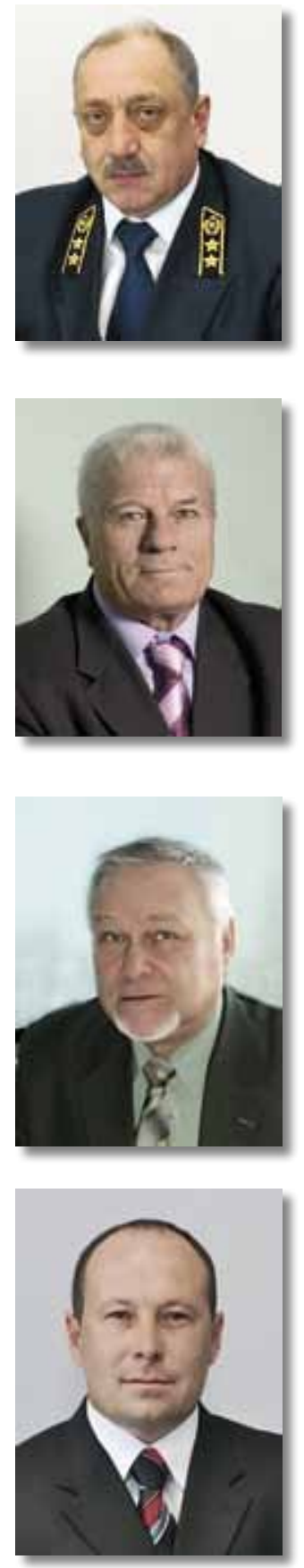

\section{ДОБРОВОЛЬСКИЙ} Александр Иванович

Канд. техн. наук, генеральный директор АО «Ургалуголь», 682030, п. Чегдомын, Хабаровский край, Россия, e-mail:DobrovolskiyAl@suek.ru

\section{ШЕВКУН Евгений Борисович} Доктор техн. наук, профессор кафердры «Транспортнотехнологические системы в строительстве и горном деле» Тихоокеанского государственного университета, 680035, г. Хабаровск, Россия, e-mail:ev.shevkun@yandex.ru

\section{ЛЕЩИНСКИЙ}

Александр Валентинович Доктор техн. наук, профессор кафедры «Транспортнотехнологические системы в строительстве и горном деле» Тихоокеанского государственного университета, 680035, Хабаровск, Россия, e-mail: lesch@sdm.khstu.ru

\section{ГАЛИМьЯнОВ}

\section{Алексей Алмазович}

Канд. техн. наук, заместитель технического директора по взрывным работам АO «Ургалуголь», 682030, п. Чегдомын, Хабаровский край, Россия, e-mail: GalimyanovAA@suek.ru
Рассмотрена проблема подготовки к выемке вмещающих пород и селективной отработки угольных пластов сложного строения на разрезе «Буреинский». Главными недостатками традиционной технологии разработки угольных пластов являются повышенный уровень рисков при формировании бульдозером площадок для бурения и дальнейшего производства буровзрывных работ и значительные трудозатраты на формирование этих площадок, а также необходимость дополнительно перемещать породу при помощи бульдозера вниз на большое расстояние под отгрузку экскаватором в автосамосвалы, а только потом приступать котработке угольного пласта. Предложена новая технология, исключающая многоэтапность традиционной технологии за счет применения валового взрывного рыхления вмещающих пород вскрыши вместе с угольными пластами, обеспечивая при этом щадящее воздействие на угольные пласты с целью сохранения их пространственного положения для обеспечения возможности их селективной выемки механическим рыхлением. Применение удлиненных зарядов небольшой массы и длины с комбинированными забойками высокой запирающей способности позволяет помимо рыхления вскрышных пород оказывать местное ослабляющее действие на угольный пласт и тем самым облегчить его механическое рыхление при последующей селективной выемке. Разработана конструкция забоечной машины, выдающей забоечный материал разной крупности и обеспечивающей механизированную установку распорных конусов в СКважины, что позволяет повысить производительность и снизить трудоемкость забоечных работ. Предложено использование транспортных контейнеров для размещения забоечного крупнокускового материала над распорными конусами для исключения повреждения проводников инициирующего импульса.

Ключевые слова: наклонный угольный пласт, забоечная машина, буровзрывные работы, транспортировка горной массы.

\section{ВВЕДЕНИЕ}

Анализ проблемы подготовки к выемке вмещающих пород и селективной отработки наклонных угольныхпластов сложного строения на разрезе «Буреинский» показал, что при всем разнообразии способов и технических средств экономически эффективная подготовка к выемке вмещающих пород на угольных месторождениях с наклонными пластами сложного строения с мерзлыми породами возможна только взрывным рыхлением. Традиционная тех- 


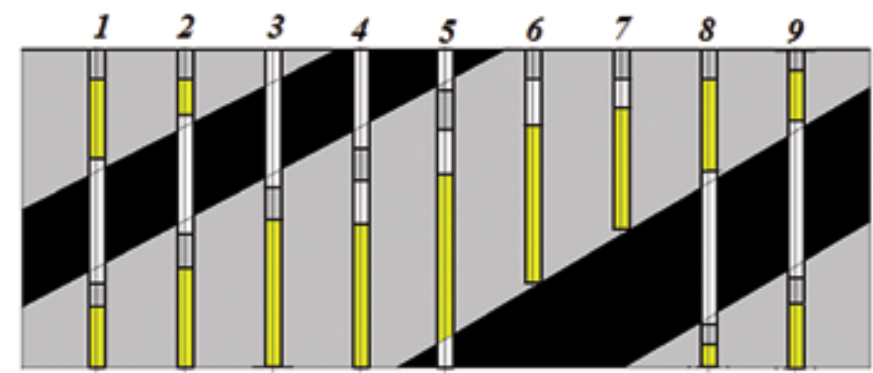

Рис. 1. Расположение скважин во вскрышных породах и угольных пластах

ig. 1. Overburden and coal seam well location

Было решено применить удлиненные заряды небольшой массы и длины, но с комбинированными забойками высокой запирающей способности. Положительные результаты промышленных экспериментальных массовых взрывов позволили разработать новую технологию валового взрывного рыхления вскрышных пород.

Взрывные скважины 1, 2, 6, 7, 8, 9 (рис. 1) во вскрышных породах над угольным пластом с переменной глубиной заряжали следующим образом.

С помощью полипропиленового рукава создавали воздушную подушку над забоем скважины длиной 0,5 м, затем в этот рукав формировали заряд, пропорциональный глубине скважины. На заряд устанавливали короткую комбинированную каменно-засыпную забойку (рис. 2).

Такая конструкция скважинного заря-

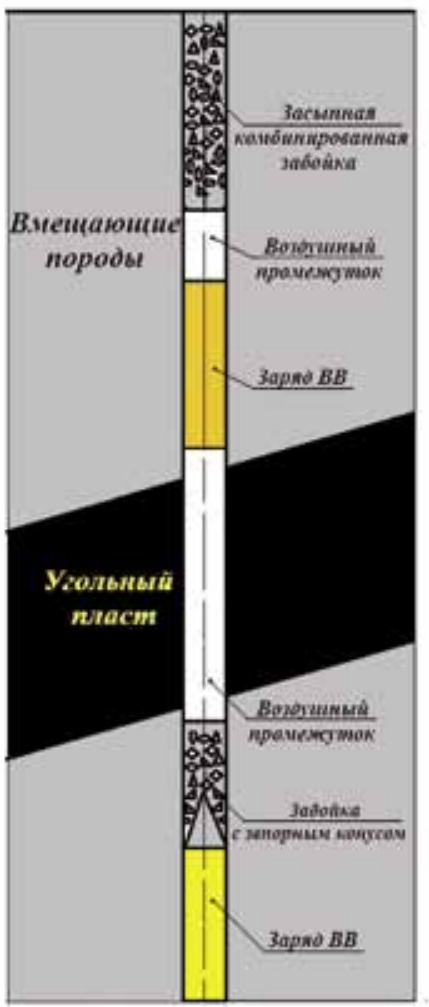
да позволяет помимо рыхления вскрышных пород оказывать местное ослабляющее действие на верхнюю часть угольного пласта и тем самым облегчить его механическое рыхление при последующей селективной выемке.

Величину зарядов ВВ скважин 1, 2, 3. 4, 5, 8, 9 (см. рис. 1) под угольным пластом уменьшали до уровня взрыва на камуфлет, чтобы исключить разубоживание угольного пласта, и формировали их следующим образом. На забой скважины размещали заряд BВ, пропорциональный глубине скважины под угольным пластом, затем устанавливали забойку, способную обеспечить камуфлет (см. puc. 2).

В связи со значительным ростом объемов взрывных работ остро поставлен вопрос механизации процесса зарядки взрывных скважин. Если промышленность достаточно полно обеспечивает горные предприятия зарядными маши-

Puc. 2. Конструкция скважины

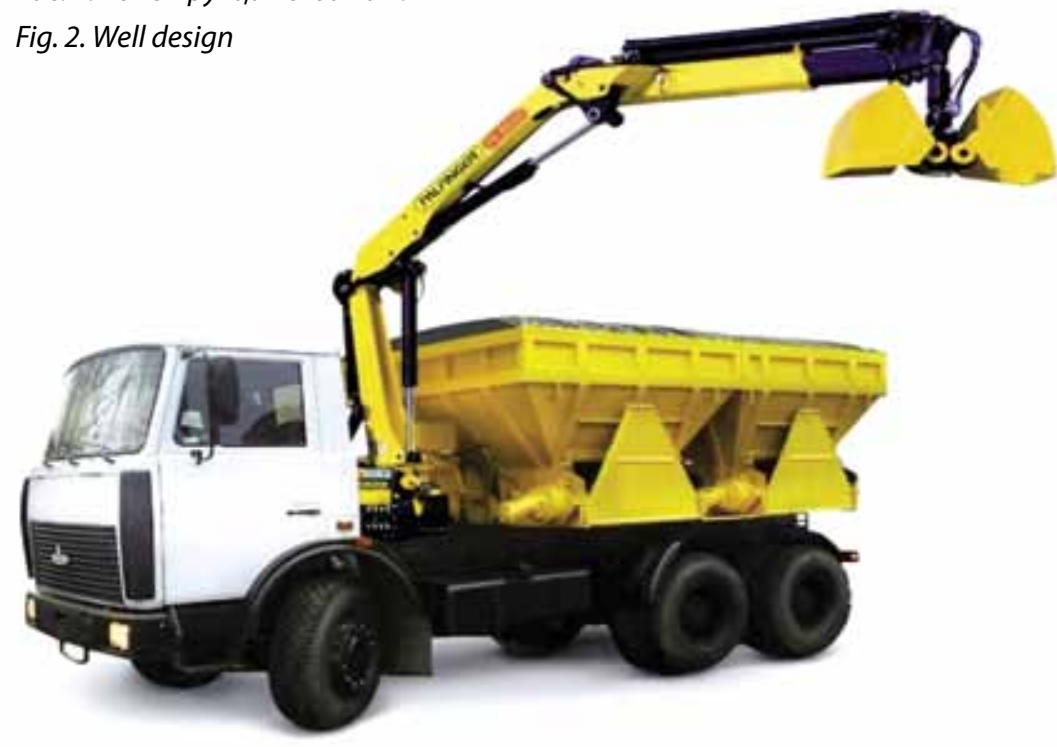

Puc. 3. Забоечная машина 3C-2M

Fig. 3. 3S-2M face cutter 
нами, то механизация забойки скважин решена не полностью $[5,6,7,8,9]$.

Промышленостью выпускается забоечная машина 3C-2М, снабженная двумя бункерами для различных фракций забоечного материала, загрузка которых осуществляется гидравлическим грейферомманипулятором, установленным на шасси автомобиля (рис. 3).

Забойка скважины производится с помощью поворотных течек, шарнирно закрепленных в нижней части бункеров. Эта машина может быть применена для забойки скважин над угольным пластом. Однако недостатком устройства является необходимость при забойке скважины перемещаться вперед-назад для послойной выдачи соответствующей фракции забоечного материала. Поэтому разработана и

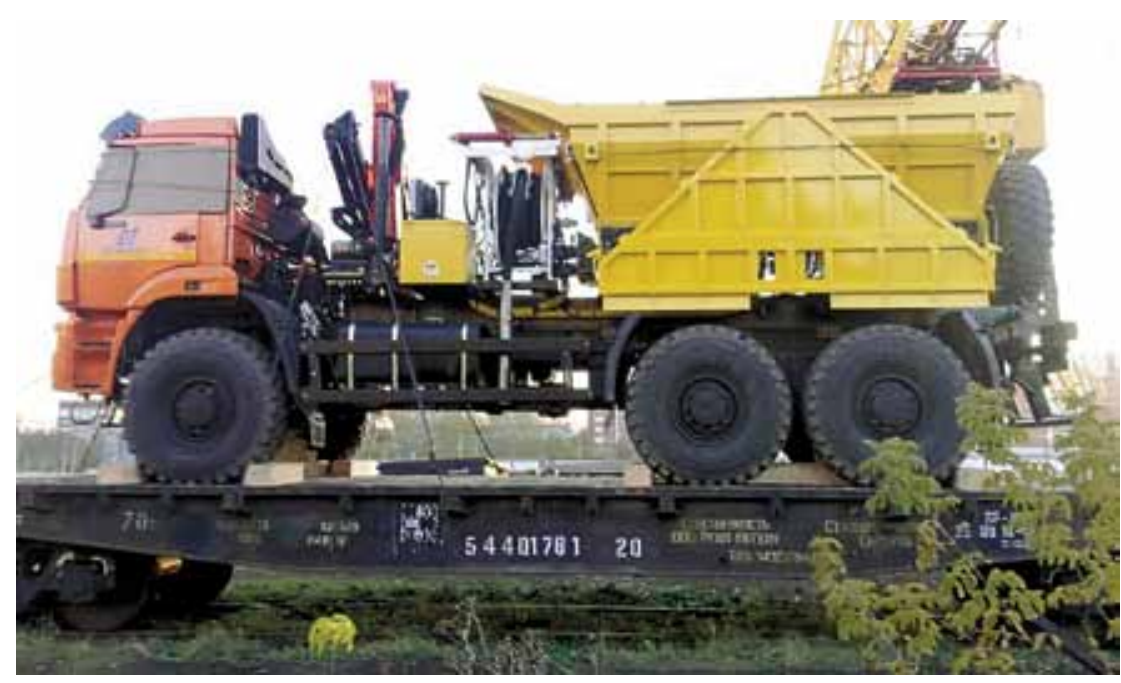

Puc. 4. Новая конструкция забоечной машины

Fig. 4. New design of face cutter изготовлена двухбункерная забоечная машина с общей течкой [10], которая подает в скважину забоечный материал отдельно крупной или мелкодисперсной фракций или же их смесь (рис. 4).

Забоечная машина выполнена на базе грузового автомобиля и снабжена передним (по ходу машины) бункером для крупной фракции с размером кусков породы 0,2-0,6 диаметра скважины и задним бункером для мелкодисперсного сыпучего материала. Забоечный материал (песок, щебень, отходы обогатительных фабрик, раздробленные вскрышные породы) захватывается гидравлическим грейфером-манипулятором (рис. 5), установленным на шасси автомобиля, и подается на двухсекционный колосниковый грохот, установленный над задним бункером. Сверхмерный материал, не прошедший сквозь отверстия верхнего яруса грохота, ссыпается на землю, а нижний класс попадает на нижний ярус колосникового грохота.

Крупная фракция с размером кусков породы 0,2-0,6 диаметра скважины ссыпается в передний бункер, а мелкодисперсный сыпучий материал попадают в задний бункер. Колосниковые решетки на грохотах выполнены сменными и установлены на рамках, входящих в пазы на раме грохота, что позволяет не только менять их по мере износа, но и при изменении диаметров взрывных скважин устанавливать решетки с соответствующими размерами отверстий.

Бункеры выполнены так, чтобы обеспечить попеременную подачу фракций забоечного материала в скважину. Разделительная стенка между бункерами установлена вертикально, а крайние стенки наклонены под углом естественного откоса несвязных материалов. После зарядки взрывных скважин забоечная машина с бункерами, заполненными забоечным материалом, выезжает на блок и устанавливается у первой скважины ряда. На дне бункеров установлены скребковые питатели, выдающие забоечный материал на общую поворотную течку (рис. 6), шарнирно закрепленную в нижней части бункеров.

Нижняя засыпная часть забойки высотой 1-1,5 диаметра скважины формируется подачей из заднего бункера мелкодисперсного материала, на нее засыпают из пе-

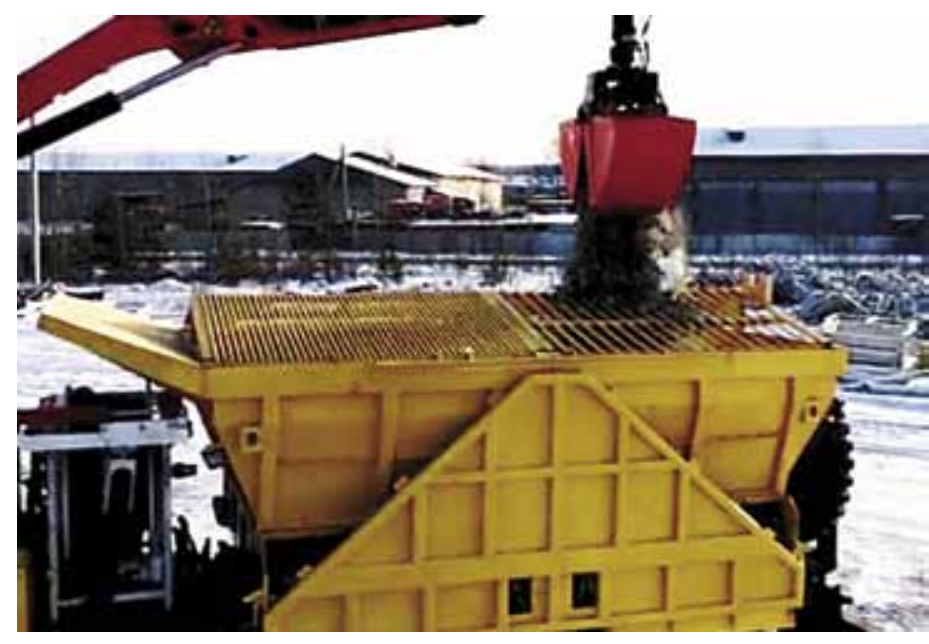

Pис. 5. Загрузка бункеров забоечным материалом

Fig. 5. Bunkering with stemming material

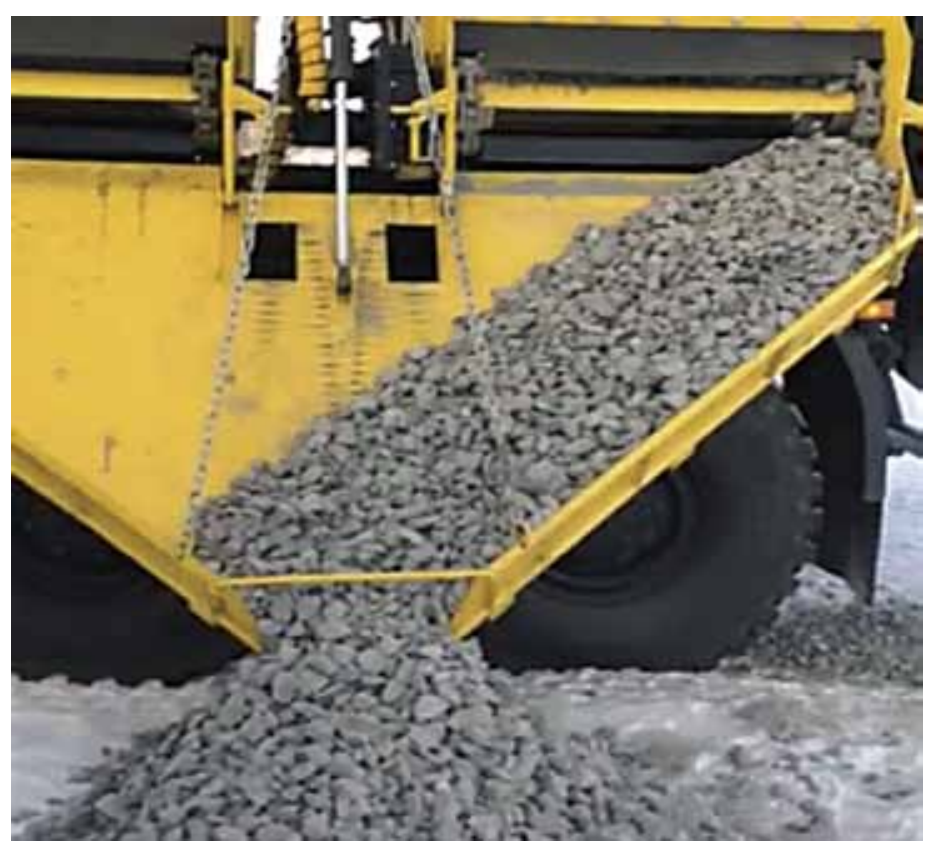

Pис. 6. Забойка скважин из бункеров

Fig. 6. Tamping holes from bunkers 
реднего бункера элементы каменного материала размером 0,2-0,6 диаметра скважины на высоту 0,5-1,5 диаметра скважины, после этого снова засыпают из заднего бункера инертный мелкодисперсный материал на высоту 1-1,5 диаметра скважины, на который опять разгружают каменный материал из переднего бункера на высоту 0,5-1,5 диаметра скважины. Процесс повторяют до полного формирования комбинированной забойки высотой не более 10 диаметров скважины. Количество подаваемого в скважину забоечного материала регулируется изменением времени работы скребковыхпитателей.

К забойке взрывных скважин под угольным пластом предъявлены повышенные требования для обеспечения камуфлета, этим условиям отвечает комбинированная забойка, выполненная в виде бетонного распорного конуса длиной 2-3 диаметра скважины (см. рис. 2), а между конусом и стенками скважины размещен крупный щебень в смеси с инертным материалом [11]. Однако распорные конусы для скважин больших диаметров обладают массой в несколько десятков килограммов, поэтому для опускания их в скважины разработано специальное оборудование [12]. Распорные конусы заранее подготавливаются для погружения в скважины. Для этого в верхней части на них закреплены шнуры длиной, обеспечивающей заданную глубину погружения распорного конуса в скважину (рис. 7).

К другому концу шнура привязана рукоятка, укладываемая на устье скважины и ограничивающая глубину погружения распорного конуса. Перед установкой в контейнеры для транспортирования конусов на взрывной блок шнур наматывается на распорный конус снизу вверх, а проволочное кольцо, закрепленное на рукоятке, надевается на вершину конуса.

Забоечная машина выезжает на блок с заряженными скважинами, выведенными наверх инициаторами взрывного импульса, и заранее разложенными распорными конусами и устанавливается у первой скважины ряда. Нижняя засыпная часть забойки высотой 1-1,5 диаметра скважины формируется подачей из заднего бункера мелкодисперсного материала в полипропиленовый чехол на глубину, обеспечивающую заданную высоту воздушного промежутка между зарядом ВВ и забойкой. После этого распорный конус захватывается за рукоятку грейферным ковшом, при подъеме витки шнура снимаются с распорного конуса. Грейфер-манипулятор поднимает распорный конус на необходимую высоту и опускает его в скважину. Затем для предотвращения перекоса распорного конуса относительно скважины из заднего бункера засыпают мелкодисперсный материал до середины распорного конуса.
Далее следует засыпка из смеси элементов каменного материала размером 0,2-0,6 диаметра скважины, перемежающаяся инертным сыпучим материалом крупностью менее 5 мм. Затем скважину заполняют до верха этим же инертным сыпучим материалом. Однако при формировании таких забоек крупнокусковые камни приобретают большую энергию и могут повредить проводник инициирующего импульса. Для устранения этого недостатка предлагается использование транспортного конвейера (рuc. 8), выполненного из металла и представляющего собой снабженное подъемным шнуром верхнее кольцо размером 0,8-0,9 диаметра скважины, на котором равномерно закреплены прутки с шагом, исключающим попадание мелких кусков каменного материала между ними [13].

Транспортный контейнер вставлен в мягкий мешок. Мешок по размеру на 30-50\% больше диаметра скважины и снабжен ушками для пропуска несущего шнура. Для формирования слоя из крупнокусковых элементов каменного материала верхней комбинированной части забойки подъемный шнур закрепляют на поверхности блока и с помощью сдвоенного несущего шнура, пропущенного через ушки мешка, контейнер подносят и опускают в скважину. После касания мешком распорного конуса несущий шнур за один конец поочередно выдергивают из ушек и за подъемный шнур вынимают из мешка контейнер, встряхивая его для лучшего высыпания элементов каменного материала, а затем удаляют его из скважины. Именно выполнение стенки контейнера из прутков обеспечивает минимальный ее контакт с элементами каменного материала и, соответственно, минимальный их зажим. А вибрация прутков при встряхивании освобождает немногие зажаоисходит полное освобождение контейтые куски, и проис
нера от камней.

Мешок под действием массы каменного материала расправляется и прижимается к стенкам скважины, копируя ее, при этом за счет плавного расползания мешок прижимает проводник инициирующего импульса к стенкам скважины, тем самым исключая возможность его повреждения при формировании слоя каменного материала комбинированной части забойки.

После формирования слоя каменного материала для обеспечения газонепроницаемости забойки в скважину снова засыпают сыпучий мелкодисперсный инертный материал до достижения высоты слоя засыпки над слоем каменного материала в 1-1,5 диаметра скважины. 
После детонации заряда ВВ в зарядной полости резко возрастает давление продуктов детонации до величин в несколько десятков тысяч атмосфер, и происходит удар газов по нижней части забойки, существенно смягченный воздушным промежутком. Начавшая движение нижняя засыпная часть забойки воздействует на основание распорного конуса, который, двигаясь вверх, расклинивает элементы каменного материала в стенки скважины, а мелкодисперсный материал забойки обеспечивает газонепроницаемость. При этом крупные камни могут разрушаться до камней среднего размера, те, в свою очередь, переходят в более мелкий щебень. Процесс носит скачкообразный характер и возникает и развивается в каждом слое заново, что в целом существенно увеличивает затраты времени на разрушение вмещающих пород и при расчетном количестве ВВ приводит к камуфлету.

\section{РЕЗУЛЬТАТЫ}

При традиционном ведении БВР с оставлением перемычек и их дальнейшей отдельной ликвидацией удельный расход ВВ составляет около 0,8 кг/м³. Фактический удельный расход ВВ при валовом взрывном рыхлении вскрышных пород составил 0,52 кг/м³. Важно отметить тот факт, что взрывание породы под угольным пластом повлияло на разупрочнение самого угольного пласта с образованием дополнительных трещин, что способствовало снижению выхода кусков угля крупной фракции при селективной выемке угля. Суммарный экономический эффект от проведения данных экспериментальных взрывов составил 16,8 млн руб.

\section{ОБСУЖДЕНИЕ}

Предложена новая технология, исключающая многоэтапность традиционной технологии за счет применения валового взрывного рыхления вмещающих пород вскрыши вместе с угольными пластами, обеспечивающая при этом щадящее воздействие на угольные пласты с целью сохранения их пространственного положения для обеспечения возможности их селективной выемки механическим рыхлением. Применение удлиненных зарядов небольшой массы и длины с комбинированными забойками высокой запирающей способности позволяет помимо рыхления вскрышных пород оказывать местное ослабляющее действие на угольный пласт и тем самым облегчить его механическое рыхление при последующей селективной выемке. Разработана конструкция забоечной машины, выдающей забоечный материал разной крупности и обеспечивающей механизированную установку распорных конусов и транспортных контейнеров для крупнокусковых элементов забойки в скважины, что позволяет повысить производительность и снизить трудоемкость забоечных работ.

\section{выводы}

При валовом взрывном рыхлении вскрышных пород удельный расход ВВ значительно снижен по сравнению с традиционным. Взрывание породы под угольным пластом разупрочняет сам угольный пласт, что способствует снижению выхода кусков угля крупной фракции при селективной выемке угля.

\section{Список литературы}

1. Демидюк Г.П. Влияние забойки на степень дробления горных пород взрывом / В.Д. Росси, Н.Ф. Андрианов, В.А. Усачев // Сб. Взрывное дело № 53/10. М.: Недра, 1963. С. 96-105.

2. Яковенко А.И. Расчет скважинных зарядов в карьерах // Сб. Взрывное дело № 51/8. М.: Недра, 1963. C. $108-120$.

3. Пат. 2526950 Российская Федерация, МПК F42D 1/08. Засыпная забойка взрывные скважин с элементами каменного материала / Шевкун Е.Б., Лещинский А.В., Шемякин С.А., Галимьянов А.А. Опубл. 27.08.2014. Бюл. № 24.

4. Пат. 2593285 Российская Федерация, МПК Е21С41/26. Способ открытой разработки группы угольных пластов с валовым взрывным рыхлением вскрышных пород / Шевкун Е.Б., Лещинский А.В., Добровольский А.И., Галимьянов А.А. Заявл. № 2015127598/03. Опубл. 10.08.2016.

5. Трубецкой К.Н., Клебанов Д.А., Ясученя С.В. Основы создания и этапы развития реализации роботизированных технологий открытых горных работ // Горный журнал. 2013. № 10. С. 67-72.

6. Трубецкой К.Н., Жариков И.Ф., Шендеров А.И. Совершенствование конструкции карьерных комплексов циклично-поточной технологии // Горный журнал. 2015. №1. С. 21-25.

7. Роботизированные горнотехнические системы при открытой разработке месторождений полезных ископаемых / К.Н. Трубецкой, Д.Я. Владимиров, И.А. Пыталев, Т.М. Попова // Горный журнал. 2016. № 5. С. 21-27.

8. Перепечаев И.Ф., Кравченко А.Н., Баширов А.В. Совершенствование буровзрывных работ в карьерах объединения // Горный журнал. 2014. № 6. С. 28-31.

9. Саитов В.И. Оптимизация комплекса средств механизации горных предприятий // Известия высших учебных заведений. Горный журнал. 2017. № 1. Стр. 86-91.

10. Пат. 2600474 Российская Федерация, MПK F42 D 1/08, F42 D 1/10, B65 G65/30. Забоечная машина для формирования короткой комбинированной забойки взрывных скважин с каменным материалом / Лещинский А.B., Шевкун Е.Б., Добровольский А.И., Галимьянов А.А. Заявл. № 2015113100/03. Опубл. 20.10.2016.

11. Пат. 2462688 Российская Федерация, MПK F42D 1/08. Комбинированная засыпная забойка скважин / Шевкун Е.Б., Лещинский А.В., Рудницкий К.А., Николаев А.С. Заявл. № 2011107822/03. Опубл. 27.09.2012. Бюл. № 27

12. Пат. 2608101 Российская Федерация. Способ формирования короткой комбинированной засыпной забойки взрывных скважин с распорным конусом и устройство для его осуществления / Лещинский А.В., Шевкун Е.Б., Комков В.Г., Рудницкий К.А., Добровольский А.И., Галимьянов А.А.

13. Пат. 25563265. Российская Федерация, МПК F42D 1/08 / Шевкун Е.Б., Лещинский А.В., Комков В.Г., Галимьянов А.А. Способ формирования короткой комбинированной забойки взрывных скважин с каменным материалом и устройство для его осуществления. Заявл. № 2014143338/03.Опубл. 20.09.2015. Бюл. № 26. 
UDC 271.3:622.233::622.235 @ A.I. Dobrovolsky, E.B. Shevkun, A.V. Leshchinsky, A.A. Galimyanov, 2018

ISSN 0041-5790 (Print) • ISSN 2412-8333 (Online) • Ugol' - Russian Coal Journal, 2018, № 4, pp. 10-15

\title{
Title
}

TAMPING MECHANIZATION EXPLOSIVE WELLS AT WORKING OFF OF INCLINED COAL LAYERS COMPLEX STRUCTURE

DOI: http://dx.doi.org/10.18796/0041-5790-2018-4-10-15

\author{
Authors \\ Dobrovolskiy A.I.', Shevkun E.B. ${ }^{2}$, Leshchinsky A.V. ${ }^{2}$, Galimyanov A.A. ${ }^{1}$ \\ 1"Urgalugol", JSC, Chegdomyn settlement, Khabarovsk region, 682030, Russian Federation \\ ${ }^{2}$ Federal State-Funded Educational Institution of Higher Education (FSFEI HE) \\ "Pacific National University", Khabarovsk, 680035, Russian Federation
}

\section{Authors' Information}

Dobrovolskiy A.I., PhD (Engineering), General Director, Deputy of the Legislative Duma of Khabarovsk Territory, e-mail: DobrovolskiyAl@suek.ru Shevkun E.B., Doctor of Engineering Sciences, Professor at Transport and Technological Systems in Construction and Mining Department, e-mail: ev.shevkun@yandex.ru

Leshchinsky A.V., Doctor of Engineering Sciences, Professor at Transport and Technological Systems in Construction and Mining Department, e-mail: lesch@sdm.khstu.ru

Galimyanov A.A., PhD (Engineering), Technical Director Deputy for Blasting Operations, e-mail: GalimyanovAA@suek.ru

\begin{abstract}
The problem of preparation for dredging of the host rocks and the selective mining of coal seams with complex structure on the cut "Bureya" is considered. The main disadvantage of the traditional technology development of coal seams is the increased level of risk. This risk is associated to site preparation for drilling using bulldozer and further drilling and blasting activities as well as high levels of labor efforts and necessity to long-distance rock movement using bulldozer down to the place of shipment to dump truck using excavator. Coal seam operations can be started only after it. The new technology is proposed. It eliminates multistage traditional technology due to the gross explosive loosening of the host rocks of overburden in conjunction with coal seams. A sparing effect on the coal seams is provided at the same time in order to preservation of their spatial position to ensure the possibility of their selective dredging using mechanical loosening. The use of long charges of small mass and the length with reliable tamping with high blocking capability makes it possible to provide a local effect of the coal seam weakening and consequently to contribute to mechanical loosening for the subsequent selective retrieval. The developed machine for tamping of wells provides stemming material of different size and enables mechanized installation of spacer cones into the well. It leads to performance improvement and reduction of labor efforts of stemming operations. Transport containers are proposed to place stemming bulk material above spacer cones to prevent damage of conductors of the initiating impulse.

Figures:
\end{abstract}

Fig. 1. Overburden and coal seam well location

Fig. 2. Well design

Fig. 3. 3S-2M face cutter

Fig. 4. New design of face cutter

Fig. 5. Bunkering with stemming material

Fig. 6. Tamping holes from bunkers

Fig. 7. Expansion cone complete set

Fig. 8. Transportation container

\section{Keywords}

Drilling and blasting operations, Sloping coal seam, Gentle loosening, Machine for the tamping of wells, Transportation of rock mass, Selective extraction.

\section{References}

1. Demidyuk G.P., Rossi V.D., Andrianov N.F. \& Usachev V.A. Influence of the face on the degree of crushing of rocks by the explosion. Explosive case, No. 53/10. Moscow, Nedra Publ., 1963, pp. 96-105.

2. Yakovenko A.I. Calculation of borehole charges in quarries. Explosive case, No. 51/8. Moscow, Nedra Publ., 1963, pp. 108-120.

3. Shevkun E.B., Leshchinsky A.V., Shemyakin S.A. \& Galimyanov A.A. Backfilling of blasting holes with elements of stone material. Patent of the Russian Federation, No. 2526950, IPC F42D 1/08, Publ. 08.27.2014, Bul. No. 24

4. Shevkun E.B., Lechinsky A.V., Dobrovolskiy A.I. \& Galimyanov A.A. The method of open development of a group of coal seams with gross explosive loosening of overburden. Patent of the Russian Federation, No. 2593285. IPC E21C41 / 26, Publ. 10.08.2016 under application No. 2015127598/03.

5. Trubetskoy K.N., Klebanov D.A. \& Yasuchenya S.V. Fundamentals of the creation and stages of the development of the implementation of the rorouted open-cast mining technologies. Gornyy Zhurnal - Mining Journal, 2013, No. 10, pp. 67-72.

6. Trubetskoy K.N., Zharikov I.F. \& Shenderov A.I. Perfection of the design of quarry complexes of cyclic-flow technology. Gornyy Zhurnal - Mining Journal, 2015, No. 1, pp. 21-25.

7.Trubetskoy K.N., Vladimirov D.Ya., Pytalev I.A., Popova T.M. Robotic mining systems with open development of mineral deposits. Gornyy Zhurnal - Mining Journal, 2016, No. 5, pp. 21-27.

8. Perepechaev I.F., Kravchenko A.N., Bashirov A.V. Perfection of drilling and blasting operations in quarries of the association. Gornyy Zhurnal - Mining Journal, 2014, No. 6, pp. 28-31.

9. Saitov V.I. Optimization of the complex of means of mechanization of mining enterprises. Izvestiya Vysshikh Uchebnykh Zavedenii. Gornyy Zhurnal - News of higher educational institutions Mining Journal, 2017, No. 1, pp. $86-91$.

10. Leshchinskiy A.V., Shevkun E.B., Dobrovolskiy A.I. \& Galimyanov A.A. Machine for the tamping of wells for forming a combined short-stemming of blast holes with stone material. Patent of the Russian Federation, No. 2600474. MPK F42 D 1/08, F42 D 1/10, B65 G65 / 30, Publ. 20.10.2016 under application No. 2015113100/03.

11. Shevkun E.B., Leshchinskiy A.V., Rudnitskiy K.A. \& Nikolayev A.S. Combined charging tamping of wells. Patent of the Russian Federation, No. 2462688. MPK F42D 1/08, Publ. 27.09.2012, Bul. No. 27 under application No. 2011107822/03.

12. Leshchinskiy A.V., Shevkun E.B., Komkov V.G., Rudnitskiy K.A., Dobrovolskiy A.I. \& Galimyanov A.A. A method of forming a combined short-loose-fill stemming of blast holes with a cone spacer and a device for its implementation. Patent of the Russian Federation, No. 2608101, Publ. 13.01.2017.

13. Shevkun E.B., Leschinsky A.V., Komkov V.G. \& Galimyanov A.A. A method of forming a short combination of stemming of blast holes with stone material and device for its implementation. Patent of Russian Federation, No. 25563265. IPC F42D 1/08, Publ. 20.09.2015, Bull. No. 26 at the request of No. 2014143338/03. 


\section{Компания «Приморскуголь» в год юбилея: 75 лет ради света и тепла}

\section{В 2018 г. компания «Приморскуголь» отмечает 75-летие.}

Приказ Наркомугля № 96 от 18 марта 1943 г. объединил в составе комбината «Приморскуголь» все предприятия угольной промышленности Приморского края: тресты «Артемуголь», «Сучануголь» и «Дальшахтострой», шахтоуправления Ворошиловское и Липовецкое, завод «Металлист» в г. Владивостоке.

Вместе со страной шахтеры Приморья прошли нелегкий путь XIX-XX вв., оставив славный след в истории угледобычи России.

В период 1960-х гг. приморские шахтеры добивались результатов высокопроизводительной работы в масштабах не только региона, но и всей страны. Ярким примером стал труд бригады Героя Социалистического Труда Василия Зубана, которая в 1966 г. на шахте «Подгородненская» поставила рекорд всесоюзного значения, достигнув 25-тысячного рубежа добычи в месяц. Тем самым престиж шахтеров Приморскугля был поднят на исключительную высоту.

Вслед за «золотым» веком угольной промышленности коллективы предприятий Приморскугля мужественно выдержали годы тяжелого кризиса 1990-х гг., смогли выстоять и сохранить преданность горняцкому делу.

В начале XXI века Приморскуголь - на этапе нового развития. С 2003 г. - компания в составе AО «Сибирская угольная энергетическая компания», одного из крупнейших угледобытчиков мира.
С приходом СУЭК приморские предприятия, построенные десятилетия назад, переживают новое рождение. Проводится мощное техническое обновление производственных активов.

Важной вехой в истории угольной отрасли Приморского края стало достижение уровня годовой добычи 5,7 млн т в 2011 г.

Максимальный уровень добычи был достигнут в разрезоуправлении «Новошахтинское» (основном производственном активе компании) - более 4,5 млн т. За период в составе СУЭК в РУ «Новошахтинское» реализуется программа техперевооружения, в рамках которой был увеличен парк большегрузных машин; произведена замена экскаваторов с прямой мехлопатой на гидравлические экскаваторы с обратной лопатой, что позволило сократить потери угля и стабилизировать ведение горных работ. На предприятии введен в эксплуатацию конвейерный комплекс по бесперебойной доставке добытого угля на технологический комплекс поверхности для его последующей переработки и отгрузки потребителям.

В 2017 г. РУ «Новошахтинское» установило рекорд по отгрузке угля за месяц в объеме 525 тыс. т. Подобный результат установлен впервые в истории предприятия.

В 2017 г. на Липовецком месторождении был построен и выдал первую тонну угля новый угольный разрез в Приморье - «Некковый» (единственный производитель каменного угля в крае).

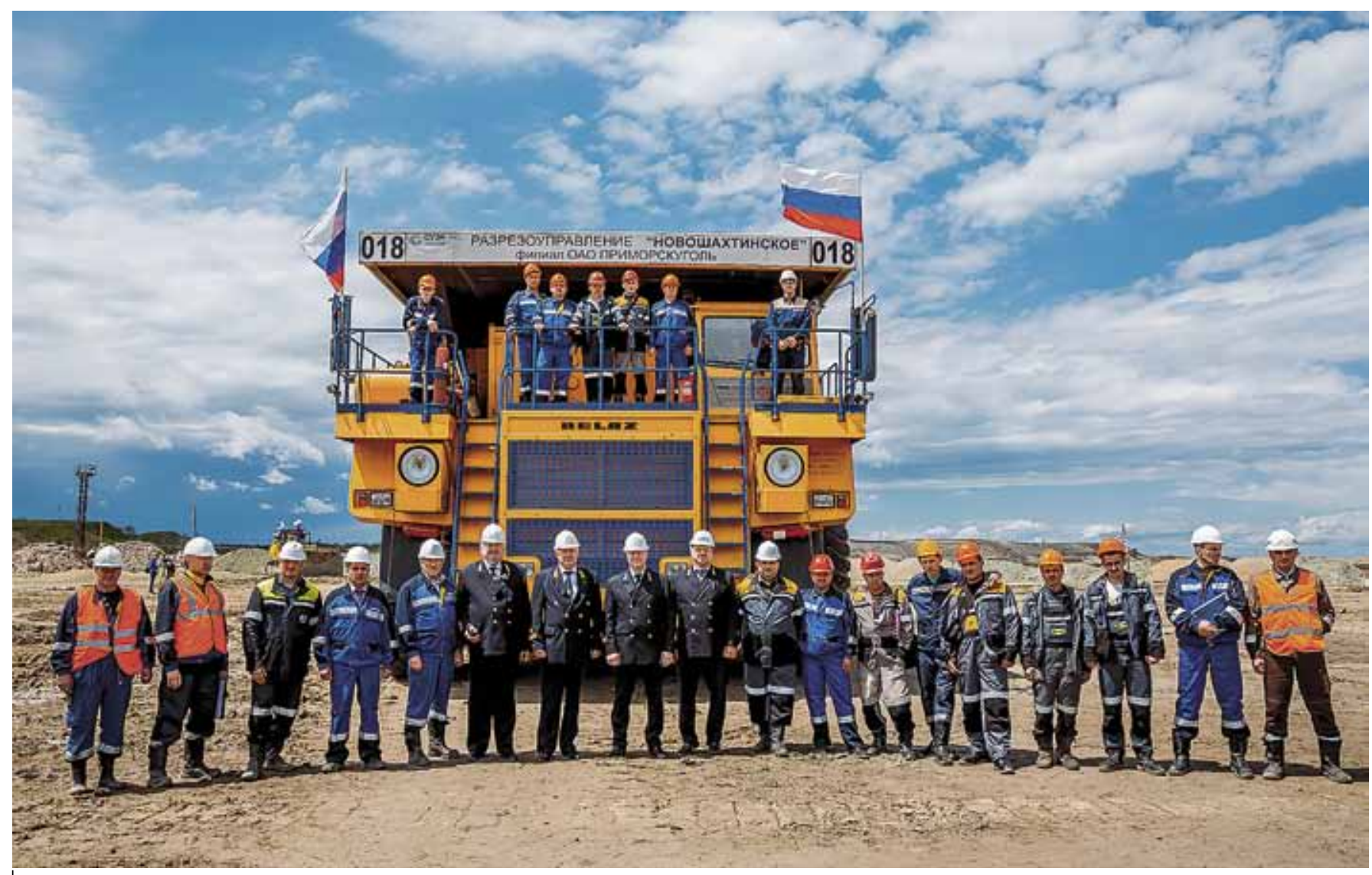




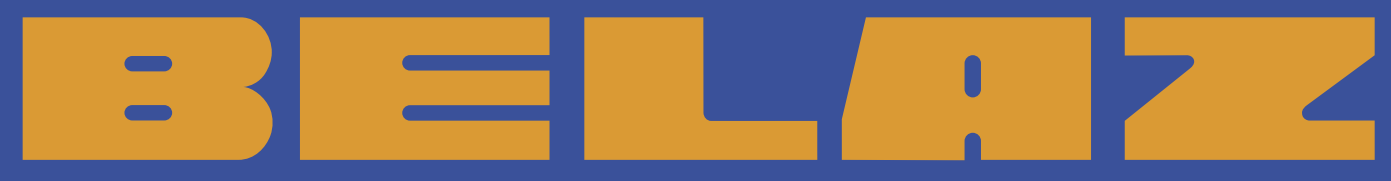

\section{EPROFI}
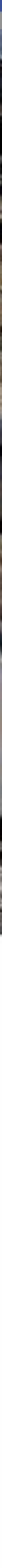

СМАЗОЧНЫЕ МАТЕРИАЛЫ И СПЕЦИАЛЬНЫЕ ЖИДКОСТИ ВЕLAZ G-Profi

- Сохраняют гарантийное обеспечение техники

- Имеют улучшенные эксплуатационные свойства

- Сопровождаются программой технической поддержки OTS BELAZ

- Позволяют снизить эксплуатационные затраты

- Способствуют увеличению межсервисных интервалов

- Всегда в наличии у дилеров БЕЛАЗ

\section{КАЧЕСТВО С ГАРАНТИЕЙ!}

По вопросам приобретения обращайтесь к официальному представителю ОАО «БЕЛАЗ»
AO «ГПФК»

107078, г. Москва, Докучаев переулок, 3, стр. 1

тел.: +7 (499) 975-10-51 www.gpfk.ru 


\section{Холдинговая компания «СДС-Уголь»: международные подходы в области менеджмента качества, экологии и охраны труда}

DOI: http://dx.doi.org/10.18796/0041-5790-2018-4-18-20

\section{РЫБАК Лев Владимирович}

Доктор экон. наук, канд. техн. наук, профессор, председатель Совета директоров

АО ХК «СДС-Уголь»,

119034, г. Москва, Россия,

e-mail: office@hcsds.ru

\section{РЫБАК Владимир Львович}

Канд. техн. наук,

президент АO «Мир Трейд АГ» (Швейцария),

119034, г. Москва, Россия,

e-mail:admin@mirtrade.ru

\section{АЛЕКСЕЕВ Геннадий Федорович}

Канд. техн. наук,

действительный член АГН,

генеральный директор АО ХК «СДС-Уголь»,

653066, г. Кемерово, Россия,

e-mail: office@sds-ugol.ru

\section{БУРЦЕВ Сергей Викторович}

Канд. экон. наук,

первый заместитель генерального директора технический директор АО ХК «СДС-Уголь»,

650066, г. Кемерово, Россия,

e-mail:s.burtsev@sds-ugol.ru

\section{ПЕРЕКРЕСТОВА Марина Геннадьевна}

Заместитель генерального директора

по управлению персоналом АО ХК «СДС-Уголь»,

653066, г. Кемерово, Россия,

e-mail:m.perekrestova@sds-ugol.ru

\section{МАКАРОВ Юрий Владимирович}

Заместитель начальника департамента перспективного развития АО ХК «СДС-Уголь», 653066, г. Кемерово, Россия, e-mail:yu.makarov@sds-ugol.ru

\section{КИСЕЛЕВ Андрей Сергеевич}

Ведущий инженер департамента ОГР АО ХК «СДС-Уголь», 653066, г. Кемерово, Россия, e-mail:a.kiselev@sds-ugol.ru
Холдинговая компания «СДС-Уголь» сертифицирована по международным стандартам ISO 9001:2015, ISO 14001:2015, OHSAS 18001:2007 и успешно прошла аудит социальной ответственности. В своей работе компания ориентируется на стандарты управления и эффективные управленческие практики, ведет непрерывное улучшение операционной деятельности, создает и внедряет в производство передовые технологии.

Ключевые слова: интегрированная система менеджмента, международный стандарт, качество, экология, безопасность труда, социальная ответственHocmb, aydum.

\section{ВВЕДЕНИЕ}

Холдинговая компания “СДС-Уголь» сертифичирована по международным стандартам ISO 9001:2015, ISO 14001:2015, OHSAS 18001:2007 и успешно прошла аудит социальной ответственности.

По результатам аудита, проведенного компанией SGS, интегрированная система менеджмента АО ХК «СДСУголь» признана соответствующей требованиям трех международных стандартов: ISO 9001:2015, ISO 14001:2015 и OHSAS 18001:2007 (puc. 1).
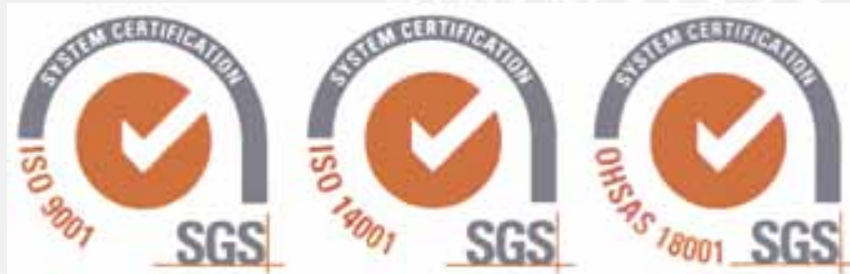

Puс. 1. Международные сертификаты соответствия под швейцарской аккредитачией SAS

Сертификаты соответствия под швейцарской аккредитацией SAS действительны с 15 марта 2018 г. в течение трех лет при условии успешного прохождения организацией ежегодных надзорных аудитов со стороны органа по сертификации.

В область сертификации АО ХК «СДС-Уголь» вошла деятельность по управлению запасами и ресурсами угля (исследования, разведка, проектирование, освоение), по 
управлению добычей и переработкой угля, по продаже угольной продукции.

Наличие сертификатов соответствия свидетельствует о том, что компания «СДС-Уголь» применяет в своей деятельности международные подходы в области менеджмента качества, экологического менеджмента, охраны здоровья и обеспечения безопасности труда.

Процесс разработки интегрированной системы менеджмента и внедрения международных стандартов длился менее года. Высокий уровень компетентности менеджеров и слаженная работа специалистов компании позволили в сжатые сроки преодолеть возникающие сложности при разработке и внедрении инновационного проекта, каким является ИСМ.

\section{ВАЖНЕЙШИЕ \\ ПРИОРИТЕТЫ ХОЛДИНГА}

Холдинговая компания «СДС-Уголь» основана в 2006 г. За 12 лет своего существования компания вышла на третье место в России по объемам добычи угля и входит В тройку крупнейших российских экспортеров угольной продукции, 92\% производимой высококачественной угольной продукции поставляется на зарубежные рынки.

ХК «СДС-Уголь» ориентируется на лучшие стандарты управления и эффективные управленческие практики, ведет непрерывное улучшение операционной деятельности, создает и внедряет в производство наилучшие доступные технологии. Нацеленное на перспективу развития высшее руководство угольного холдинга считает важнейшими приоритетами своей работы повышение качества продукции, повышение уровня промышленной безопасности и охраны труда, бережное природопользование и защиту окружающей среды, а также качественные трудовые отношения.

\section{ПРОМЫШЛЕННАЯ}

\section{И ЭКОЛОГИЧЕСКАЯ БЕЗОПАСНОСТЬ}

Холдинг «СДС-Уголь» последовательно реализует проекты, направленные на обеспечение безопасных условий труда, в области промышленной и экологической безопасности.

В феврале 2018 г. Федеральная служба Ростехнадзора провела выездное совещание, посвященное актуальным проблемам промышленной и экологической безопасности в угольной отрасли России. Площадкой такого масштабного и значимого мероприятия для всех угледобывающих компаний России, как итоговый «круглый стол» по вопросам безопасности на опасных производственных объектах угольной промышленности, выбрана компания АО ХК «СДС-Уголь» в рамках секции «Открытые горные работы».

В 2017 г. Холдинг «СДС-Уголь» вошел в первую пятерку рейтинга экологической ответственности горнодобывающих и металлургических компаний Всемирного фонда дикой природы (WWF). По итогам всесторонней оценки компания «СДС-Уголь» заняла пятое место и лидирующее положение среди угледобывающих компаний России.

Внедрение стандартов в области экологического менеджмента (ISO 14001), охраны здоровья и обеспечения безопасности труда (OHSAS 18001) является для АO XK «СДС-Уголь» важнейшим достижением и позволит Компании уверенно управлять рисками в области промышленной безопасности, охраны труда и экологии.

\section{КАЧЕСТВО}

\section{УГОЛЬНОЙ ПРОДУКЦИИ}

Продукция угольных предприятий Холдинга - это высококачественный энергетический и коксующийся уголь, добываемый открытым и подземным способами.
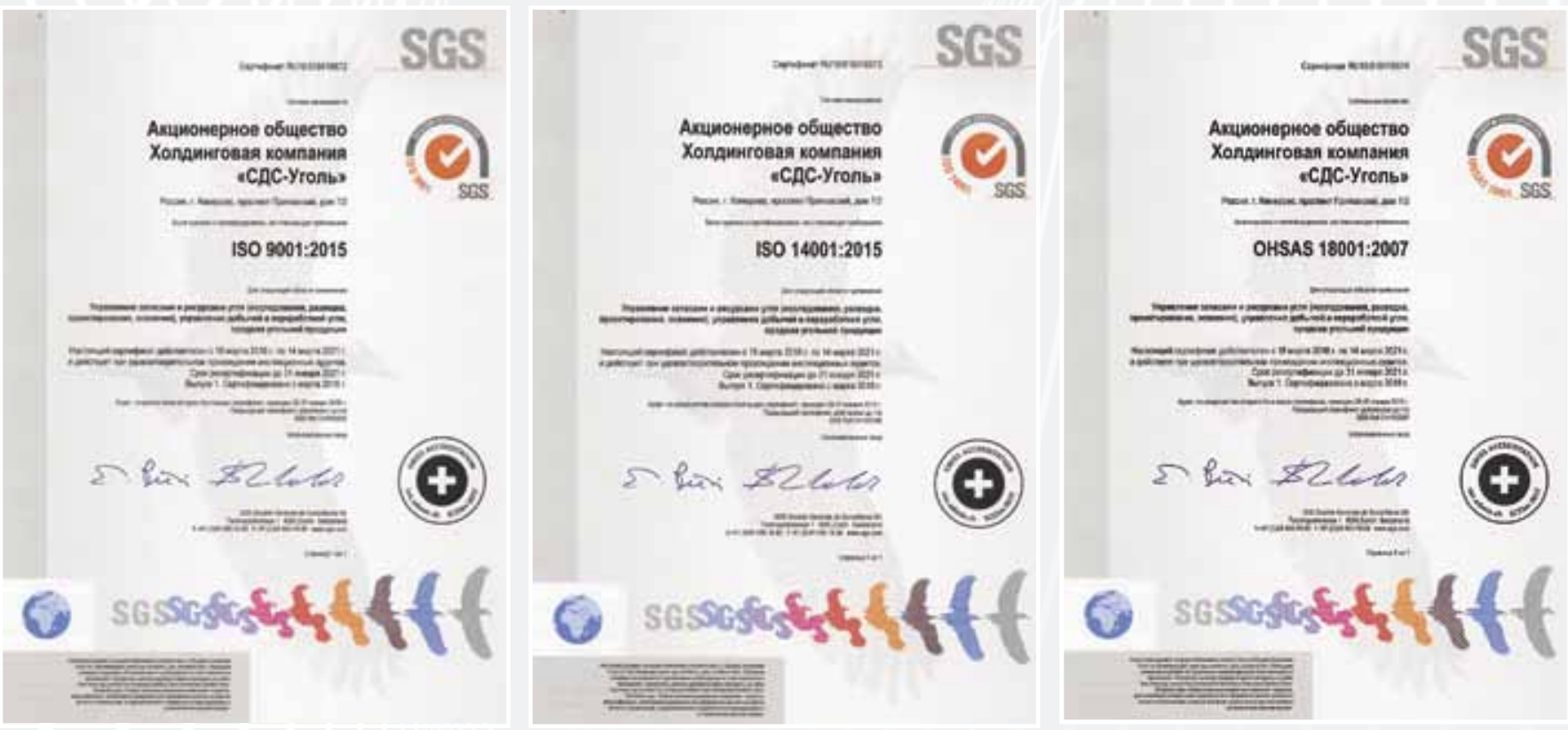

Pис. 2. Сертификаты соответствия АО ХК «СДС-Уголь» требованиям трех международных стандартов: ISO 9001:2015; ISO 14001:2015; OHSAS 18001:2007 
Сегодня в ХК «СДС-Уголь» созданы условия, исключающие появление брака и снижающие до минимума риски на всех стадиях и процессах производства и потребления продукции - от разведки, проектирования и развития производства до хранения, отгрузки, транспортировки и использования продукции конечным потребителем.

На всех угледобывающих предприятиях и обогатительных фабриках Холдинга действует система строгого контроля качества продукции, обеспечивающая:

- контроль качества добываемых, перерабатываемых и отгружаемых углей на каждом этапе технологического процесса;

- соответствие качества продукции требованиям ГОСТов и контрактным обязательствам;

- оперативное взаимодействие с потребителями по вопросам качества продукции.

Основной способ повышения качества продукции -увеличение объемов и глубины переработки угля. Обогащение угля снижает его зольность и повышает калорийность, что позволяет поставлять высококачественную продукцию с высокой добавленной стоимостью и повышать рентабельность бизнеса.

Для повышения качества продукции Холдинга реализованы инвестиционные проекты по модернизации обогатительных и сортировочных мощностей и повышению их эффективности.
ХК «СДС-Уголь» зарекомендовала себя как ответственный поставщик, надежный партнер, обеспечивающий строгое исполнение контрактных обязательств, стремящийся максимально удовлетворить требования потребителей к качеству, объему, срокам отгружаемой продукции и предупредить претензии к качеству.

В 2017 г. Холдинговая компания «СДС-Уголь» стала партнером международной ассоциации Bettercoal и официальным поставщиком угля для Ассоциации угольных потребителей.

Интеграция стандарта ISO 9001 в систему менеджмента позволит Компании управлять рисками в области качества продукции и, тем самым, повысить уверенность потребителей в выборе угольной продукции АО ХК «СДС-Уголь» (puc. 2).

\section{ЗАКЛЮЧЕНИЕ}

Благодаря сертификационному аудиту получено мнение независимых экспертов на качество системы управления, которое позволяет наглядно демонстрировать потребителям, что Холдинговая компания «СДС-Уголь» надежный поставщик угольной продукции по качеству, срокам и объемам, надежный партнер и социально ориентированная Компания, опирающаяся на принципы безопасного труда, рациональное природопользование, профессионализм и энтузиазм сотрудников.

UDC 658.56:622.33:622.85:338.45.005.6 @ L.V. Rybak, V.L. Rybak, G.F. Alekseev, S.V. Burtsev, M.G. Perekrestova, Yu.V. Makarov, A.S. Kiselev, 2018 ISSN 0041-5790 (Print) • ISSN 2412-8333 (Online) • Ugol' - Russian Coal Journal, 2018, № 4, pp. 18-20

\section{Title}

"SBU-COAL" HOLDING COMPANY: THE INTERNATIONAL APPROACHES IN THE FIELD OF QUALITY MANAGEMENT, ECOLOGY AND LABOR SAFETY

DOI: http://dx.doi.org/10.18796/0041-5790-2018-4-18-20

\section{Authors}

Rybak L.V. ${ }^{1}{ }^{2}$, Rybak V.L. ${ }^{3}$, Alekseev G.F. ${ }^{2}$, Burtsev S.V. ${ }^{2}$, Perekrestova M.G. ${ }^{2}$, Makarov Yu.V. ${ }^{2}$, Kiselev A.S. ${ }^{2}$

1 "Siberian Business Union" holding company, JSC, Moscow, 119034, Russian Federation

2 "SBU-Coal" Holding Company JSC, Kemerovo, 650066, Russian Federation

3 "MIRTRADE AG" (Switzerland) JSC, Moscow, 119034, Russian Federation

\section{Authors' Information}

Rybak L.V., Doctor of Economics Sciences, PhD (Engineering), Professor, Vice-president, Chair of the Board of Directors, e-mail: office@hcsds.ru Rybak V.L., PhD (Engineering), President, e-mail: admin@mirtrade.ru

Alekseev G.F., PhD (Engineering), Member of the Academy of Mining Sciences, General Director, e-mail: office@sds-ugol.ru

Burtsev S.V., PhD (Economic), First Deputy General Director, Technical Director, e-mail: s.burtsev@sds-ugol.ru

Perekrestova M.G., Head Personnel Department, e-mail: m.perekrestova@sds-ugol.ru

Makarov Yu.V., Deputy chief Perspective development Department, e-mail: yu.makarov@sds-ugol.ru

Kiselev A.S., Leading engineer Surface Department, e-mail: a.kiselev@sds-ugol.ru

\section{Abstract}

"SBU-Coal" Holding Company is certified in the international ISO standards 9001, ISO 14001, OHSAS 18001. Holding Company is guided by standards of management and effective administrative practicians, conducts continuous improvement of operating activities, creates and introduces advanced technologies in production.

\section{Keywords}

Certificate, International standard, ISO 9001, ISO 14001, OHSAS 18001, Audit of social responsibility, Innovation, Management, Quality management, Human resource management, Ecology, Safety. 


\section{Пресс-служба АО ХК «СДС-Уголь» информирует Молодые инженеры холдинговой компании "СДС-Уголь" состязались в решении кейсов}

В АО ХК «СДС-Уголь» (входит в состав АО ХК «СДС») состоялся Чемпионат по решению кейсов в области горного дела среди молодых работников компании.

К решению были представлены три инженернотехнических кейса: «Технические решения по снижению влияния открытых горных работ на населенные пункты», «Мероприятия по снижению стоимости 1 куб. м взорванной горной массы» и «Оптимальные схемы и режимы работы горношахтного оборудования, направленные на достижение максимально эффективного использования оборудования».

Экспертной комиссией оценивались техническая и экономическая эффективность решений, оригинальность, эрудиция, логика и качество презентации инженернотехнического кейса. Всего в Чемпионате приняли участие 7 команд: АО «Черниговец», ООО «Шахтоуправление «Майское», ООО «Шахта Листвяжная», АО «Салек», «Шахта «Южная» (Филиал $\mathrm{AO}$ «Черниговец»), $\mathrm{AO}$ «Прокопьевский угольный разрез», ООО «СИГД».

В ходе проведения Чемпионата при решении инженерно-технического кейса «Мероприятия по снижению стоимости 1 куб. м взорванной горной массы» экспертное жюри признало победителем команду «Убойная сила» (ООО «Шахтоуправление «Майское»). Команда «Южане» («Шахта «Южная» - Филиал АО «Черниговец») с решением кейса «Оптимальные схемы и режимы работы горнотранспортного и горношахтного оборудования, направленные на достижение максимально эффективного использования оборудования» заняла второе место. На третьем месте с решением кейса «Технические решения по снижению влияния открытых горных работ на населенные пункты» - команда ООО «Сибирский Институт Горного Дела» (СИГД).

«Метод решения кейсов применяется нами для обучения молодых специалистов, формирования у них навыков подготовки и принятия обоснованных инженерных и управленческих решений, совершенствования и поиска новых актуальных идей. Привлекая их к участию в подобных Чемпионатах, мы даем нашей талантливой молодежи толчок для саморазвития, - комментирует первый заместитель генерального директора - технический директор АО ХК «СДС-Уголь» Сергей Буриев. - Подводя итоги прошедшего Чемпионата, хочу отметить, что наши перспективные горные инженеры в очередной раздоказали, что могут мыслить нестан- дартно ивесьмаэффективно решать предложенные производственные задачи».

Чемпионаты по решению кейсов в области горного дела проводятся в рамках основных направлений Кадровой политики АО ХК «СДС-Уголь». Целями Чемпионата являются: развитие профессионального и личностного потенциала перспективных молодых специалистов предприятий АО ХК «СДС-Уголь»; получение опыта творческой и исследовательской деятельности, позволяющего повысить компетентность и квалификацию сотрудников при рассмотрении реальных производственных задач. Проведение Чемпионата как эффективного инструмента по формированию кадрового резерва предприятий из числа молодых специалистов, наиболее адаптированных к работе на реальном производстве, помогает стимулировать инновационную деятельность в решении производственных задач, осуществлять преемственность знаний от опытных работников с широкой производственной практикой к перспективным молодым специалистам АО ХК «СДС-Уголь».
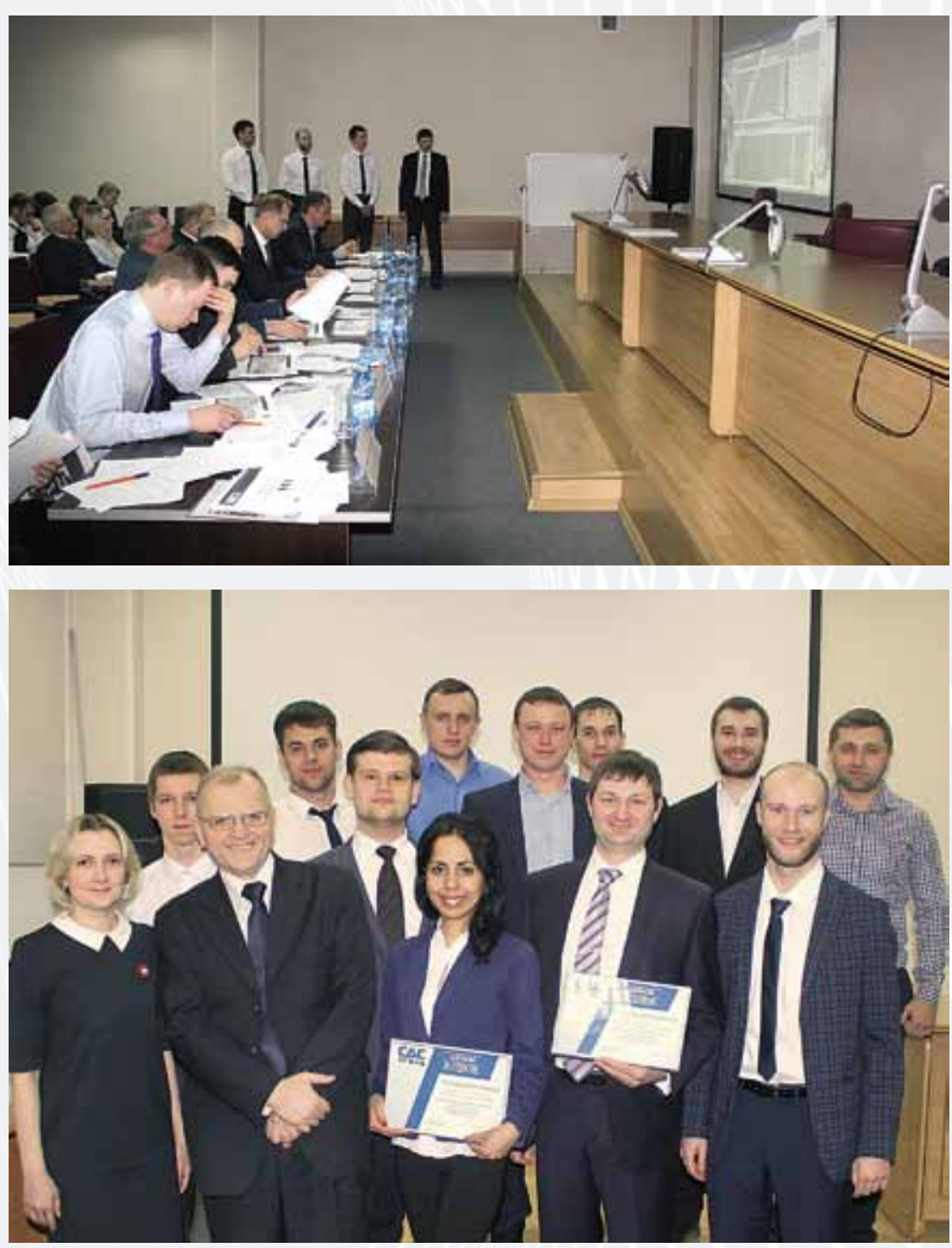


\section{Пути решения инновационных задач в угольной промышленности}

DOI: http://dx.doi.org/10.18796/0041-5790-2018-4-22-25

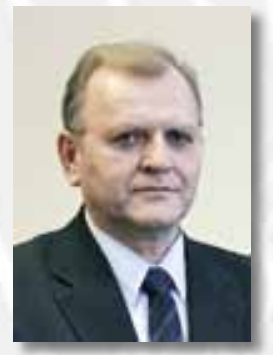

\author{
ЕФИМОВ Виктор Иванович \\ Доктор техн. наук, \\ профессор НИТУ «МИСИС», \\ заместитель директора \\ по перспективному развитию \\ Филиала АО ХК «СДС-Уголь» в г. Москве, \\ 119034, г. Москва, Россия, \\ e-mail:v.efimov@sds-ugol.ru
}

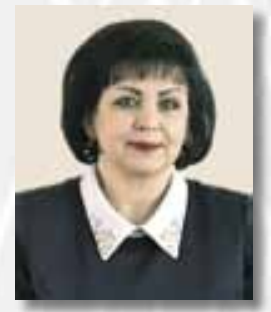

КОРЧАГИНА Татьяна Викторовна

Канд. техн. наук,

Директор ООО «Сибирский Институт

Горного Дела»

(АО ХК «СДС-Уголь»),

653066, г. Кемерово, Россия,

e-mail: t.korchagina@sds-ugol.ru

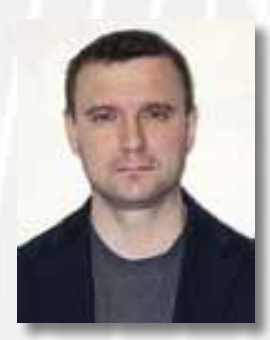

\section{КОЛЫЧЕВ Александр Сергеевич}

Заместительгенерального директора ОООТД «СДС-Трейд» (АОХК «СДС-Уголь»), 650066, г.Кемерово, Россия, e-mail:a.kolychev@sds-ugol.ru

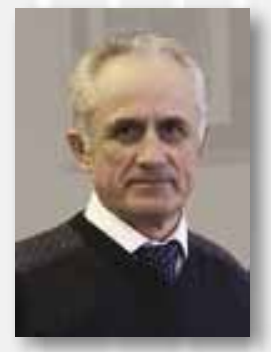

\section{МитичКИн Сергей Иванович}

Начальник отдела

специальных разделов

ООО «Сибирский Институт Горного

Дела»

(АОХК «СДС-Уголь»),

653066, г. Кемерово, Россия,

e-mail:s.mitichkin@sds-ugol.ru

Применение наиболее оптимальныхспособови формуправления инновационной деятельностью наугольныхпредприятиях позволило выработать методику применения такой формы организации, как временный творческий коллектив (BTK), и применить его на практике какинструмент при решении задач импортозамещения запасных частей к горнотранспортному оборудованию на разрезах АО ХК «СДС-Уголь». Ключевые слова: инновация, стратегия развития и мотивачия, управление производством, инструмент решения инновационныхзадач, принципы работы временного творческого коллектива, импортозамещение.

\section{ВВЕДЕНИЕ}

Уголь, как главный стратегический энергоресурс, на сегодняшний день - гарант энергетической безопасности подавляющего большинства стран мирового сообщества.
Однако, чтобы конкурировать на мировом рынке необходимо в первую очередь снижать себестоимость его добычи. А это достигается прежде всего управлением инновационной деятельностью на предприятиях $[1,2,3]$.

На угольных предприятиях созрела необходимость применения радикальных изменений, основанных на новых знаниях, что обусловливается в основном двумя обстоятельствами:

- во-первых, как правило, наблюдается, большой разрыв между появлением «нового знания» и его технологическим использованием;

- во-вторых, проходит много времени до того, как новая технология материализуется в новом процессе.

В этой связи нововведения, основанные на новых знаниях, требуют ясного понимания преследуемой цели, организации предпринимательского управления $[4,5,6]$.

\section{ОПТИМИЗАЦИЯ ИННОВАЦИОННОЙ ДЕЯТЕЛЬНОСТИ}

Главные предпосылки для активизации инновационной деятельности предприятий состоят как раз в том, что все средства производства, применяемые технологии и оборудование - все то, что износилось, устарело, стало тормозом к выполнению планируемых показателей работы предприятия, необходимо систематически обновлять и совершенствовать.

То есть инновационная деятельность в угольной промышленности, на наш взгляд, - это деятельность, направленная на поиск и реализацию новых передовых идей в целях совершенствования технологии и организации производства, применения высокопроизводительного оборудования и качественный контроль за выполнением регламентных работ при его эксплуатации $[7,8]$.

Целевая и систематическая деятельность управления производством в идеале должна быть направлена на ориентированное планирование по разработке и внедрению нововведений на всех сквозных стадиях цикла «наука техника - производство» $[9,10]$.

Такая схема работала при социализме, например в Научно-производственном объединении (НПО) «Прокопьевскгидроуголь», деятельность которого была основана на взаимодействии предприятий с научными учреждениями и экспериментальными заводами на основе выполнения научно-исследовательских и опытно-конструкторских работ (НИОКР) с изготовлением опытных образцов техники и технологий, испытанием и внедрением их в производство.

Сегодня угольным компаниям, имея ограниченный финансовый ресурс, эффективнее внедрять инновации при минимальных рисках. Оптимизация инновационной деятельности при решении насущных проблем предприятий при существующих ограничениях, по нашему мнению, может быть эффективно представлена таким орга- 
низационным инструментом, как временный творческий коллектив (ВТК), организуемый для разработки и производства новых типов ненаукоемкой техники и технологий и наделяемый значительной автономией в рамках выполнения одной или нескольких задач. Разработка технологических проектов и создание новых образцов техники должны предусматривать все этапы работ ВТК - от выдачи исходных данных заказчиком до внедрения опытных образцов и технологий в производство [11, 12].

Это работа, требующая знаний, изобретательности, таланта, и ее успех зависит от сосредоточенной работы команды лучших работников (такие есть на угледобывающих предприятиях), мотивированных на инновационную деятельность [13, 14].

Достижению высокого уровня эффективной работы команды помогает сформированная стратегия инновационного развития предприятия, основанная на мотивации совершенствования организации производства и приобретения навыков научно-практической деятельности.

\section{СТРАТЕГИЯ ИННОВАЦИОННОГО РАЗВИТИЯ ПРЕДПРИЯТИЯ}

Стратегия инновационного развития предприятия состоит из пяти основных блоков.

Первый блок. Приобретение теоретических и практических знаний по следующим курсам обучения:

- «Практика бережливого производства»;

- «Постановка задач и делегирование полномочий»;

- «Навыки системного мышления»;

- «Основные принципы построения и решения задач с применением ТРИЗ».

Второй блок. Проведение чемпионатов по решению инженерных кейсов с привлечением студентов институтов и университетов.

Третий блок. Получение передового опыта и знаний посредством проведения скайп-лекций. Организация серии «мини-лекций» от опытных тренеров (без их приезда на предприятие). По сути, это «Клуб молодых ученых», но в удаленном формате и с меньшей долей интерактивного участия слушателей. Возможно совмещение этих мероприятий.

Четвертый блок. Ежемесячная планерка как обеспечение планомерного развития посредством периодической оценки общего хода работ в целом. Проводится ежемесячная очная встреча с главными специалистами холдинга «Сибирский Деловой Союз» (кураторами проекта, назначенными приказом по холдингу) и с активными участниками рационализаторского движения. На встрече рассматривается ход рационализаторских проектов в целом, обсуждаются вопросы применения методических инструментов, ставятся задачи на следующий месяц.

Пятый блок. Конференции, конкурсы и семинары как основные катализаторы профессионального развития. Организуется большая ежегодная конференция, где молодые кадры могут обменяться опытом, методическими инструментами своей работы и рассказать о достигнутых результатах. К дням профессиональных праздников в холдингах и на предприятиях компании «СДС» проводятся смотр и конкурсы в номинациях, наиболее актуальных для той или иной отрасли. По результатам конкурсов победителям и призерам выплачивается вознаграждение или осуществляются другие виды поощрений.

Для успешного ведения инновационной деятельности значительную роль играет умение видеть задачи и проблемы производства. Для этого публикуются задачи в формате постоянного сбора информации на портале «Рационализаторство». В дальнейшем задачи по их сложности, трудоемкости и продолжительности решения, формируются в тематический план с последующим рассмотрением и утверждением на Научно-техническом Совете компании. Выполнение задач обеспечивается формированием организационной структуры (ВТК), основным признаком которой, является профессионализм ее участников.

\section{ПРАКТИКА ПРИМЕНЕНИЯ ПРИОБРЕТЕННЫХ НАВЫКОВ ИННОВАЦИОННОЙ ДЕЯТЕЛЬНОСТИ ПО РЕШЕНИЮ ЗАДАЧ ИМПОРТОЗАМЕЩЕНИЯ ЗАПАСНЫХ ЧАСТЕЙ К ГОРНОТРАНСПОРТНОМУ ОБОРУДОВАНИЮ}

Идея: изготовление ковша Hitachi EX-1200 в условиях механических мастерских АО ХК «СДС-Уголь».

Первый шаг. Образование временного творческого коллектива (ВТК) в составе: представитель заказчика (руководитель ВТК); сотрудник проектного института; рабочие и специалисты механических мастерских; сотрудники литейного завода.

Второй шаг. Планирование деятельности временного творческого коллектива:

- разработка конструкторской и технологической документации на изготовление узлов и деталей ковша (puc. 1);

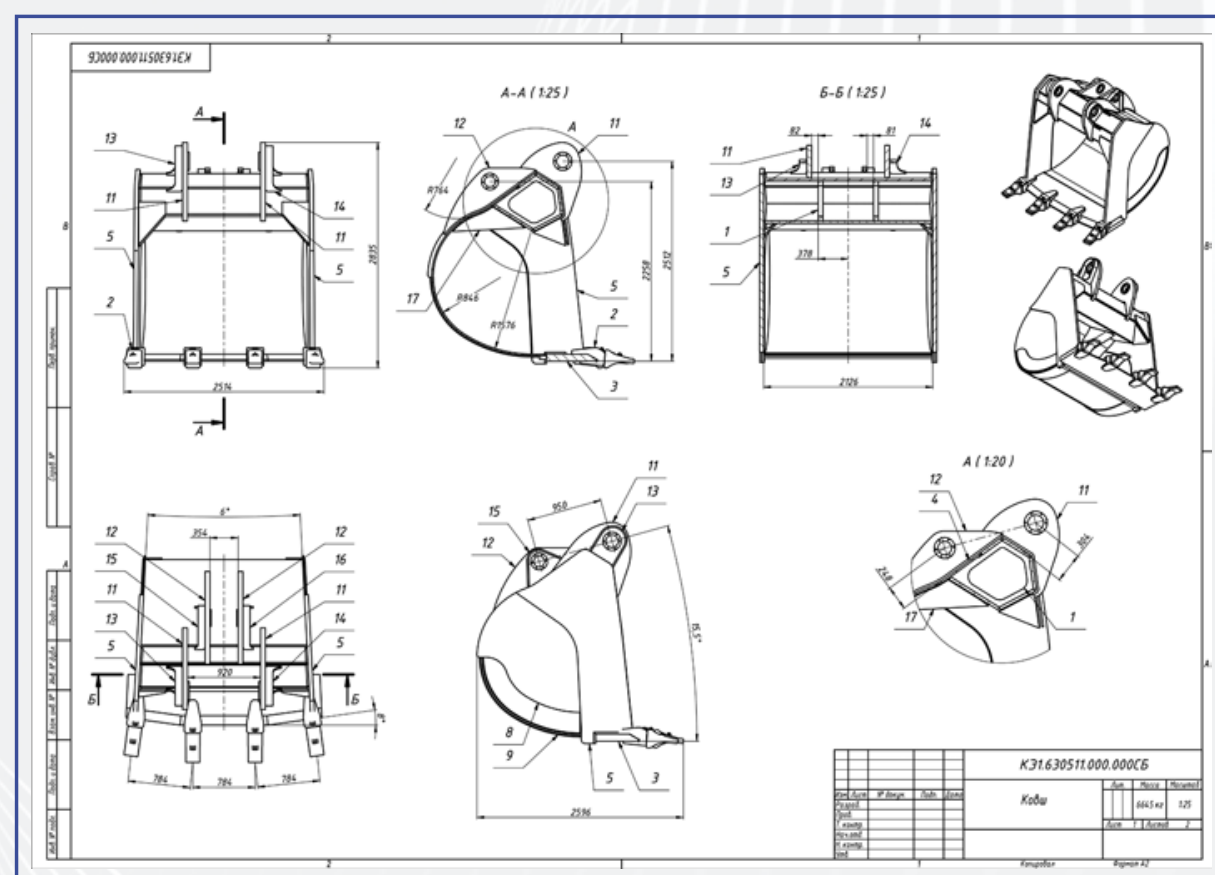

Pис. 1. Чертеж ковша 

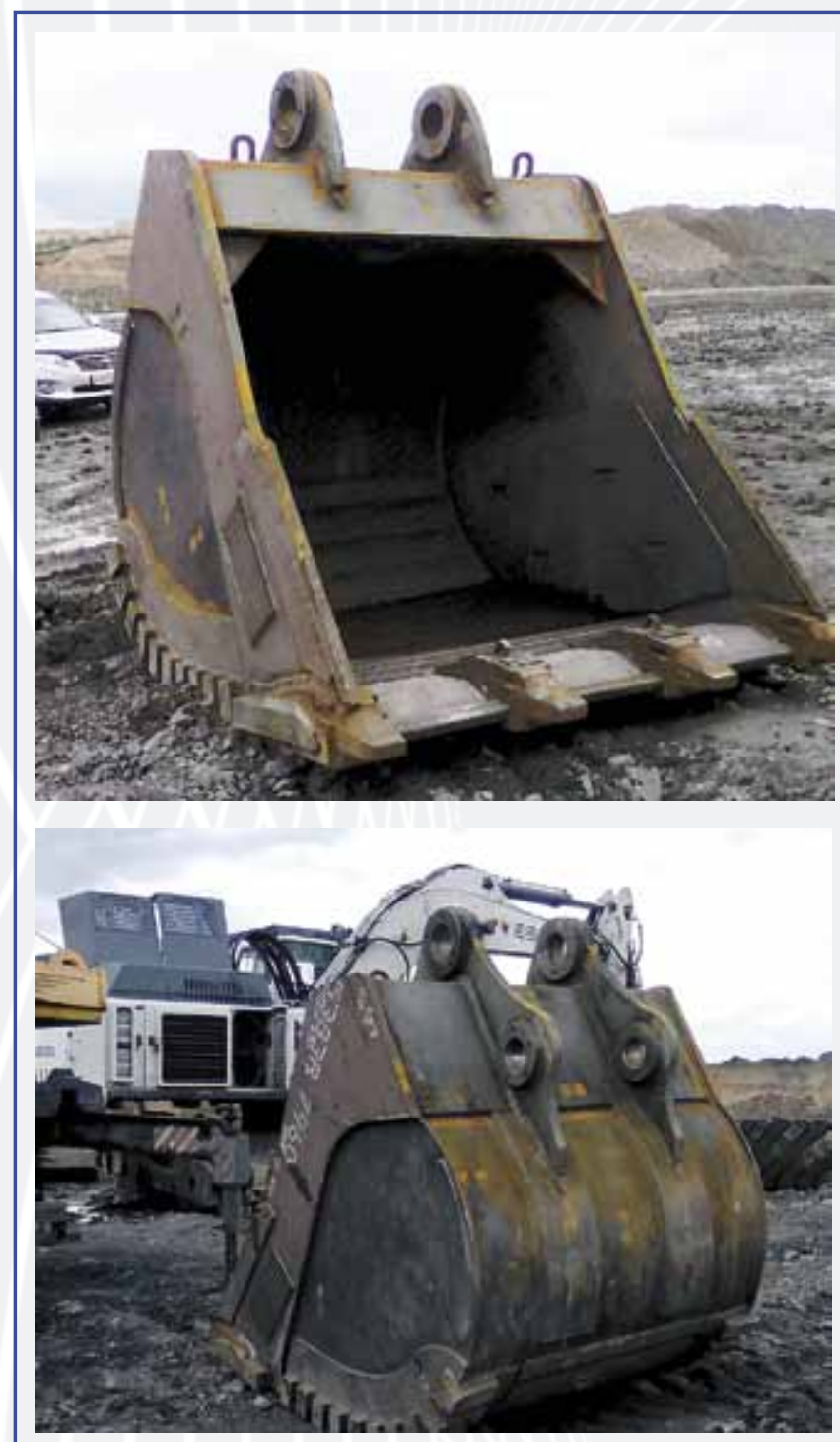

Puc. 2. Изготовление ковша Hitachi EX-1200 в условиях механических мастерских АО ХК «СДС-Уголь»

- технологическая подготовка производства узлов и деталей горнотранспортного оборудования;

- производство и реализация узлов и деталей ковша;

- контроль за использованием деталей и узлов в период гарантийного срока эксплуатации.

третий шаг. Изготовление ковшей экскаваторов в условиях механических цехов шахт и разрезов:

- подготовка производства (технологическая оснастка, материально-техническое снабжение);

- изготовление комплектующих и запасных частей изделия силами Рубцовского филиала ОАО «Алтайвагон» (рuс. 2).

\section{ЗАКЛЮЧЕНИЕ.}

\section{ПРЕИМУЩЕСТВА ЕДИНИЧНОГО ПРОИЗВОДСТВА} ОБРАЗЦОВ ТЕХНИКИ В УСЛОВИЯХ МЕХАНИЧЕСКИХ МАСТЕРСКИХ

Замена применяемых ранее на ковшах литых деталей (межзубьевая защита, боковые режущие кромки, крышка адаптеров) на детали собственного производства (сварной вариант) с наплавкой твердосплавными элементами отечественного производства дала угольным предприятиям АО ХК «СДС-Уголь» следующие выгоды:

- менее продолжительный срок выполнения: конструкторских и технологических работ, изготовления и проведения испытаний изделий;

- меньшая стоимость по сравнению с импортными аналогами;

- более продолжительный срок службы по сравнению с импортными аналогами за счет применения высоколегированных сталей и технологических решений;

- возможность унификации узлов и деталей во время проектирования изделия;

- гибкая система ценообразования;

- экономия денежных средств на производстве изделий (экономический эффект составил 400 тыс. руб. на одно изделие);

- возможность производства капитального ремонта по разработанным чертежам.

\section{Список литературы}

1. Рационализация и изобретательство / В.И. Ефимов, П.М. Федяев, Т.В. Корчагина, С.И. Митичкин. Кемерово, 2018.

2. Ефимов В.И., Митичкин С.И. Управление рационализаторской деятельностью на предприятиях АО ХК «СДСУголь» //Уголь. 2016. № 4. С. 20-22. URL: http://www.ugolinfo. ru/Free/042016.pdf (дата обращения 15.03.2018).

3. Ефимов В.И., Попов С.М., Федяев П.М. Методические основы организации привлечения инноваций для решения эколого-экономических задач в современных условиях. В сборнике: Повышение качества образования, современные инновации в науке и производстве / Сборник трудов Международной научно-практической конференции. Прокопьевск, 2015. С. 120-122.

4. Ефимов В.И., Попов С.М., Федяев П.М. Методические основы организации подготовки кадров с учетом перспектив инновационного развития угольной отрасли. В сборнике:Повышение качества образования, современные инновации в науке и производстве / Сборник трудов Международной научно-практической конференции. Прокопьевск, 2015. С. 122-124.

5. Ефимов В.И.Управление качеством:учебное пособие / Под ред. Е.Ю. Граве. М., 2014.

6. Ефимов В.И. Развитие рационализаторского движения на предприятиях ОАО ХК «СДС-Уголь» // Уголь. 2013. № 3. C. 100-103. URL: http://www.ugolinfo.ru/Free/032013. pdf (дата обращения 15.03.2018).

7. Ефимов В.И., Рыбак Л.В.Управление персоналом: учебное пособие. М., 2009.

8. Myaskov A.V., Popov S.M., Efimov V.I. The methodological principles of the organization of public-private partnerships for innovation development of mining enterprises in the economic crisis. Miners Week - 2015. Reports of the XXIII International Scientific Symposium. 2015. P. 178-184.

9. Ефимов В.И., Корчагина Т.В., Митичкин С.И. Положение о рационализаторской и изобретательской деятельности на предприятиях, входящих в группу лиц ЗАО ХК «СДС» - ООО «Сибирский Институт Горного Дела». Кемерово, 2017. 48 с.

10. Ефимов В.И., Корчагина Т.В., Митичкин С.И. Сборник методических материалов по организации изобретательской и рационализаторской деятельности предприятий. Кемерово, 2017. 95 с. 
11. Ефимов В.И. Приоритетные инновационные направления ОАО ХК «СДС-Уголь» / Сборник тезисов докладов III Международной научно-практической конференции «ТехГорМет 21-век». СПб.: НМСУ «Горный», 2012. С. 48-49.

12. Ефимов В.И., Сидоров Р.В., Корчагина Т.В. ООО «Прокопгипроуголь»: К новым горизонтам! // Уголь. 2014. № 5. C. 64-65. URL: http://www.ugolinfo.ru/Free/052014.pdf (дата обращения 15.03.2018).
13. Ефимов В.И., Попов С.М., Федяев П.М. Формирование экономико-правовых инструментов государственночастного партнерства для инновационного развития предприятий Кузбасса в условиях кризиса. Тула: Изд-во ТулГУ, 2015.99 с.

14. Ефимов В.И., Попов С.М., Калачёва Л.В. Основные задачи подготовки кадров угольной промышленности сучетом инновационного развития отрасли и предложения по их решению // Известия Тульского государственного университета. Науки о Земле. 2016. № 4. С.179-183.

INNOVATIONS

UDC 608.2:658.314.72:658.5:622.33(571.17) @ V.I. Efimov, T.V. Korchagina, A.S. Kolychev, S.I. Mitichkin, 2018

ISSN 0041-5790 (Print) • ISSN 2412-8333 (Online) • Ugol' - Russian Coal Journal, 2018, № 4, pp. 22-25

\section{Title}

Ways of solving innovative tasks in the coal industry

DOI: http://dx.doi.org/10.18796/0041-5790-2018-4-22-25

\section{Authors}

Efimov V.I. ${ }^{1,2}$, Korchagina T.V. ${ }^{3}$, Kolychev A.S. ${ }^{4}$, Mitichkin S.I. ${ }^{3}$

1 "SBU-Coal" Holding Company JSC, Moscow Branch, Moscow, 119034, Russian Federation

${ }^{2}$ National University of Science and Technology "MISIS" (NUST "MISIS"), Moscow, 119049, Russian Federation

3 "Mining Engineering Institute of Siberia" LLC, Kemerovo, 653066, Russian Federation

4 "SBU-Treyd" Trading House LLC, Kemerovo, 650066, Russian Federation

\section{Authors' Information}

Efimov V.I., Doctor of Engineering Sciences, Professor, Deputy Director for Future Development, e-mail: v.efimov@sds-ugol.ru

Korchagina T.V., PhD (Engineering), Director, e-mail: t.korchagina@sds-ugol.ru

Kolychev A.S., Deputy General Director, e-mail: a.kolychev@sds-ugol.ru

Mitichkin S.I., Specialized Departments Manager,

e-mail: s.mitichkin@sds-ugol.ru

\section{Abstract}

Application of the most optimal methods and forms of innovation activity management in coal enterprises allowed to develop the methodology of use of such a form of organization as a temporary creative team and to use it in practice as a tool when solving the tasks of import replacement of spare parts to the mining equipment in open pits of "SBU-Coal" Holding Company JSC.

\section{Keywords}

Innovation, Development strategy and motivation, Production management, Tool for solving innovative tasks, Temporary creative team work principles, Import replacement.

\section{References}

1. Efimov V.I., Fedyaev P.M., Korchagina T.V. \& Mitichkin S.I. Ratsionalizatsiya i izobretatel'stvo [Rationalization and invention]. Kemerovo, 2018.

2. Efimov V.I. \& Mitichkin S.I. Upravlenie ratsionalizatorskoy deyatel'nost'yu na predpriyatiyakh AO KhK "SDS-Ugol'" [Innovative initiatives management in "SBU-Coal"Holding Company OJSC enterprises]. Ugol'- Russian Coal Journal, 2016, No. 4, pp. 20-22. Available at: http://www.ugolinfo.ru/Free/042016.pdf (accessed 15.03.2018)

3. Efimov V.I., Popov S.M. \& Fedyaev P.M. Metodicheskie osnovy organizacii privlecheniya innovacij dlya resheniya ehkologo-ehkonomicheskih zadach sovremennyh usloviyah [Methodical principles of innovations involvement for environmental-economical problems solution under current conditions] In the collection of articles: Povyshenie kachestva obrazovaniya, sovremennye innovacii v nauke i proizvodstve [Eduction quality improvement, modern innovations in production]. Sbornik trudov Mezhdunarodnojnauchno-prakticheskoj konferencii [Collection of international scientific and practical conference essays]. Prokop'evsk, KuzSTU branch Publ., 2015, pp. 120-122.

4. Efimov V.I., Popov S.M. \& Fedyaev P.M. Metodicheskie osnovy organizacii podgotovki kadrov s uchetom perspektiv innovacionnogo razvitiya ugol'noj otrasli [Methodical principles of company personnel training with account for the coal industry innovative development]. In the collection of articles: Povyshenie kachestva obrazovaniya, sovremennye innovacii v nauke i proizvodstve [Eduction quality improvement, modern innovations in production] Sbornik trudov Mezhdunarodnojnauchno-prakticheskojkonferencii [Collection of international scientific and practical conference essays]. Prokop'evsk, KuzSTU branch Publ., 2015, pp. 122-124.

5. Efimov V.I. Upravlenie kachestvom: Uchebnoe posobie [Quality management: Educational aid.]. Under editorship of Grave E.Yu. Moscow, 2014.

6. Efimov V.I. Razvitie racionalizatorskogo dvizheniya na predpriyatiyah OAO HK "SDS-Ugol"' [Innovative incentives management in "SBU-Coal" HC OJSC enterprises]. Ugol' - Russian Coal Journal, 2013, No. 3, pp. 100-103. Available at: http://www.ugolinfo.ru/Free/032013.pdf (accessed 15.03.2018).

7. Efimov V.I. \& Rybak L.V. Upravlenie personalom: Uchebnoe posobie [Personnel management. Educational aid.]. Moscow, 2009.

8. Myaskov A.V., Popov S.M. \& Efimov V.I. The methodological principles of the organization of public-private partnerships for innovation development of mining enterprises in the economic crisis. Miners Week - 2015. Reports of the XXIII International Scientific Symposium, 2015, pp. 178-184.

9. Efimov V.I., Korchagina, T.V. \& Mitichkin S.I. Polozhenie o ratsionalizatorskoy i izobretatel'skoy deyatel'nosti na predpriyatiyakh, vkhodyashchikh $v$ gruppu lits ZAO KhK "SDS" [Regulation on rationalization and inventive activities at facilities belonging to the group of persons of CJSC KhK "SBU"]. Kemerovo, "Mining Engineering Institute of Siberia" LLC, 2017, 48 p.

10. Efimov V.I., Korchagina T.V. \& Mitichkin S.I. Sbornik metodicheskih materialov po organizacii izobretatel'skoj i racionalizatorskoj deyatel'nosti predpriyatij [Collection of methodological materials on the organization of inventive and rationalization activities of enterprises]. Kemerovo, 2017, 95 p.

11. Efimov V.I. Prioritetnye innovatsionnye napravleniya OAO KhK "SDS-Ugol"' [Priority Innovative directions of "SBU-Coal" Holding Company JSC]. Book of abstracts of the 3-d International Theoretical and Practical Conference "Tekhgormet-21st Century". Saint-Petersburg, National University of Mineral and Raw Materials "Gorniy" Publ., 2012, pp. 48-49.

12. Efimov V.I., Sidorov R.V. \& Korchagina T.V. OOO «Prokopgiprougol'»: Knovym gorizontam! ["Prokopgiprougol"LLC: towards new horizons!]. Ugol' Russian Coal Journal, 2014, No. 5, pp. 64-65. Available at: http://www.ugolinfo. ru/Free/052014.pdf (accessed 15.03.2018).

13. Efimov V.I., Popov S.M. \& Fedyaev P.M. Formirovanie ekonomiko-pravovyh instrumentov gosudarstvenno-chastnogo partnerstva dlya innovacionnogo razvitiya predpriyatij Kuzbassa v usloviyah krizisa [Generation of economical legal tools of public - private partnerships for Kuzbass enterprises innovation development in the economic crisis]. Tula, TulSTU Publ., 2015, 99 p.

14. Efimov V.I., Popov S.M. \& Kalacheva L.V. Osnovnye zadachi podgotovki kadrov ugol'noy promyshlennosti s uchetom innovatsionnogo razvitiya otrasli i predlozheniya po ikh resheniyu [The main objectives of training of the coal industry taking into account innovative development of branch and the offer on their decision]. Izvestiya Tul'skogo gosudarstvennogo universiteta. Nauki o Zemle - Bulletin of the Tula State University. Earth Sciences, 2016, No. 4, pp. 179-183. 


\section{Комплексный подход в области промышленной безопасности}

\section{и охраны труда}

DOI: http://dx.doi.org/10.18796/0041-5790-2018-4-26-30

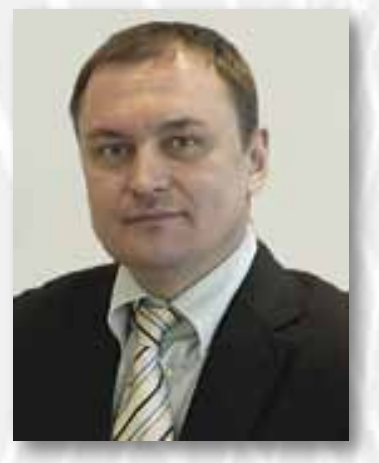

БУРЦЕВ Сергей Викторович

Канд. экон. наук, первый заместитель генерального директора технический директор АО ХК «СДС-Уголь», 650066, г. Кемерово, Россия, e-mail:s.burtsev@sds-ugol.ru

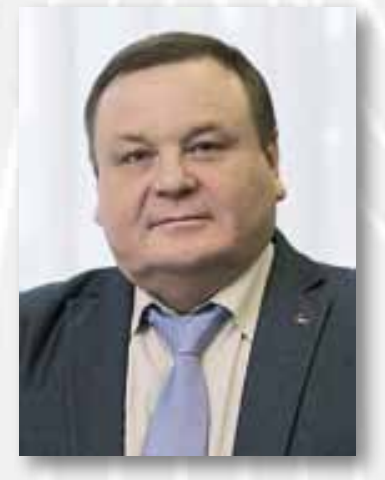

БАСЫРОВ Олег Фаинович Заместительгенерального директора по ПК иОТ АО ХК «СДС-Уголь», 650066, г. Кемерово, Россия, e-mail: o.basyrov@sds-ugol.ru

Рассказывается обуспехах компании «СДС-Уголь» в области улучшения промышленной безопасности и охраны труда, создании и внедрении «Комплексной программы повышения уровня промышленной безопасности и охраны труда на предприятиях АО ХК «СДС-Уголь» на 2018-2020 годы». Ключевые слова: компания «СДС-Уголь», промышленная безопасность, охрана труда, опасные производственные объекты, системный подход, комплексная программа, кадровый вопрос, инновационные проекты.

\section{ВВЕДЕНИЕ}

Холдинговая компания «СДС-Уголь» - одна из ведущих компаний России по добыче и экспорту угольной продукции. В составе компании четыре разреза, две шахты, четыре обогатительные фабрики, собственный проектный институт и ряд сервисных предприятий.

Всего в АО ХК «СДС-Уголь» эксплуатируется 51 опасный производственный объект (см. таблицу).

Средняя численность работников, занятых на опасных производственных объектах, составляет 7303 чел., или
75\% от общего количества. В связи с этим в СДС-Угле ведется планомерная работа по концентрации значительных ресурсов для изучения и внедрения самых передовых практик по снижению уровня производственного травматизма. Как лидер отрасли СДС-Уголь обязан соответствовать лучшим мировым стандартам в обеспечении безопасных и здоровых условий труда [1].

\section{ПОЛИТИКА КОМПАНИИ В ОБЛАСТИ ПБ И ОТ}

Сохранение жизни человека путем обеспечения безопасных условий труда всегда было и остается одной из первостепенных задач в компании «СДС-Уголь».

Политикой АО ХК «СДС-Уголь» в области промышленной безопасности и охраны труда определено, что главная ценность угольного холдинга - это Люди, поэтому основным приоритетом деятельности компании является безопасность ее работников, а также работников сторонних организаций и посетителей, участвующих в производственной деятельности.

Каждый руководитель, специалист, рабочий способствует соблюдению требований промышленной безопасности при эксплуатации опасных производственных объектов, постоянному улучшению условий труда, снижению и исключению воздействия вредных и опасных производственных факторов.

Все проектные решения в области техники и технологии рассматриваются в первую очередь с точки зрения обеспечения промышленной безопасности, охраны труда и безопасности труда работников.

Каждый руководитель, специалист, рабочий осуществляет свою деятельность безопасно.

Каждый руководитель отвечает за безопасность и здоровье подчиненных ему работников в рамках действующего законодательства.

Каждый работник несет ответственность за свою личную безопасность и способствует обеспечению безопасности своих коллег.

Но все это не будет гарантировать полной безопасности, пока не изменится отношение к дисциплине труда каждого работника.

Опасные производственные объекты

\begin{tabular}{|c|c|}
\hline Класс опасности ОПО & Количество ОПО \\
\hline Класс опасности I & 5 \\
\hline Класс опасности II & 26 \\
\hline Класс опасности III & 8 \\
\hline Класс опасности IV & 12 \\
\hline
\end{tabular}




\section{СИСТЕМНЫЙ ПОДХОД}

Управление промышленной безопасностью и охраной труда на угольных предприятиях - это сложная задача, требующая комплексного системного подхода [2, 3], которая не может быть решена в отрыве от общей системы управления предприятием и должна учитывать: применяемые технологии, состояние оборудования [4], производственных зданий, сооружений, квалификацию и навыки руководителей, специалистов и непосредственных исполнителей работ.

В связи с этим в апреле 2017 г. разработана и введена в производственные процессы, а в ноябре - сучетом положительного опыта в области промышленной безопасности - актуализирована «Комплексная программа повышения уровня промышленной безопасности и охраны труда на предприятиях АО ХК «СДС-Уголь» на 2018-2020 годы».

Анализируя производственную деятельность компании, видно, что при увеличении объема производства (добычи, вскрыши, проходки горных выработок и коэффициента вскрыши) за период 2015-2017 гг. произошло снижение общего количества случаев травматизма на $35,7 \%$.

Комиссиями по расследованию несчастных случаев выявлены корневые причины смертельных несчастных случаев [5], а также разработаны мероприятия по устранению причин несчастных случаев со смертельным исходом.

Для снижения уровня травматизма на предприятиях компании и обеспечения безопасных условий труда в 2017 г. был разработан и реализован комплекс предупредительных мероприятий.

23 и 27 марта 2017 г. руководителями Сибирского управления Ростехнадзора совместно с руководителями АО ХK «СДС-Уголь» и акционерами проведено два совещания по улучшению состояния промышленной безопасности. По итогам данных совещаний были разработаны и реализованы мероприятия, направленные на снижение травматизма и улучшение состояния промышленной безопасности. В том числе, на заседаниях ПДК на каждом предприятии детально проработаны акты плановых выездных проверок Сибирского управления Ростехнадзора. При проведении комплексных проверок состояния ПБ и ОТ на предприятиях холдинга руководителями и специалистами АО ХК «СДС-Уголь» использовались акты плановых выездных проверок Ростехнадзора других предприятий холдинга, проведенных ранее.

При проведении проверок состояния ПБ и ОТ на предприятиях холдинга руководителями и специалистами АО ХК «СДС-Уголь» привлекались кучастию в проверкахпредставители предприятий для проведения взаимопроверок. Все проверки проводятся по чек-листам.

По результатам анализа состояния энергохозяйства предприятий холдинга разработана программа повышения уровня энергообеспеченности и энергозащищенности предприятий АО ХК «СДС-Уголь». Кроме того, разработан и реализован план мероприятий, направленный на снижение риска возникновения чрезвычайных ситуаций на эксплуатируемых объектах и уменьшение экономического ущерба от аварий, инцидентов и несчастных случаев $[6,7]$.

Актуализированы и введены в действие пять основополагающих локальных нормативных документов в области промышленной безопасности:
- «Положение о единой системе управления промышленной безопасностью и охраной труда АО ХК «СДС-Уголь»;

- «Положение о производственном контроле соблюдения требований промышленной безопасности при эксплуатации опасных производственных объектов АО ХК «СДС-Уголь»;

- «Порядок расследования причин инцидентов на опасных производственных объектах, гидротехнических сооружениях, их учета и анализа»;

- методика «Оценка рисков аварий, инцидентов и несчастных случаев на предприятиях АО ХК «СДС-Уголь»;

- регламент «Расследование происшествий на производстве внутренними комиссиями предприятий» (определение корневых причин).

Выполнение вышеуказанных мероприятий позволило в 2017 г. повысить эффективность корпоративного управления в области промышленной безопасности и охраны труда, укрепить исполнительскую дисциплину руководителей, специалистов и рабочих, соответствовать требованиям законодательства РФ и международным стандартам в области интегрированной системы менеджмента качества, экологии, профессионального здоровья и безопасности.

\section{РЕАЛИЗАЦИЯ «КОМПЛЕКСНОЙ ПРОГРАММЫ»}

Для снижения уровня травматизма в 2017 г. были реализованы следующие мероприятия «Комплексной программы повышения уровня промышленной безопасности и охраны труда на предприятиях АО ХК “СДС-Уголь» на 2018-2020 годы»:

- утверждена пятилетняя программа реновации оборудования. Только в 2017 г. для модернизации и замены морально и физически устаревшего оборудования на предприятиях открытых горных работ приобретена техника наилучших образцов импортного и отечественного производства [8], в том числе экскаваторы - девять ед.; автосамосвалы - 19 ед.; бульдозеры - 11 ед. Для предприятий, ведущих добычу угля подземным способом, приобретены: очистной комплекс - 1 ед.; проходческий комплекс - 2 ед.; оборудование системы МФСБ; вспомогательное оборудование. Реновационные меры повлияли не только на улучшение производственных показателей, но и позволили значительно улучшить состояние промышленной безопасности;

- для обеспечения требований промышленной безопасности внедрены и функционируют на предприятиях АО ХК «СДС-Уголь» системы дистанционного мониторинга:

- с целью осуществления постоянного мониторинга геодинамического состояния массива в АО «Черниговец» установлены три радиолокационные системы контроля устойчивости бортов SSR Cround Probe [9]. При превышении критических значений возникает аварийный сигнал и выводится уведомление на компьютерах горного диспетчера, маркшейдера группы мониторинга для информирования руководителей предприятия и принятия решения о прекращении работ и выводе людей и оборудования из опасной зоны (рис. 1);

- для эффективного и безопасного управления производственным процессом на предприятиях открытых горных работ компании используется автоматизированная 


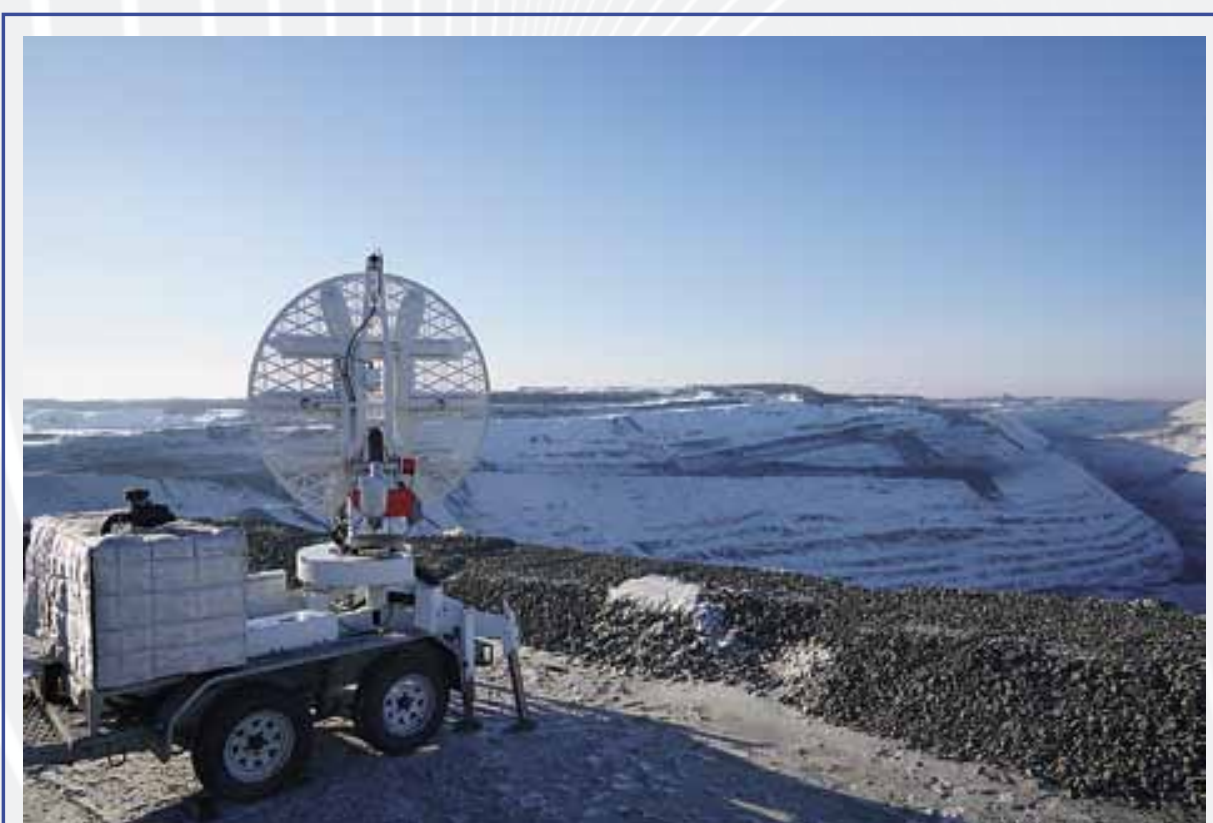

PUс. 1. Радиолокачионная система контроля устойчивости бортов SSR Cround Probe

При приеме на работу и в период трудовой деятельности осуществляется всестороннее тестирование персонала на профпригодность по трем методикам: шестнадцатифакторный личностный опросник Кеттелла; опросник А.Г. Шемелевой; методика оценки внимания «Таблицы Шульте». В 2017 г. прошли тестирование 1133 человека.

В Положение об оплате труда предприятий внесено дополнение, в котором установлена коллективная ответственность работников за нарушение требований промышленной безопасности в части начисления надбавки за безопасный труд.

По итогам 2017 г. было премировано 998 работников предприятий компании, выполняющих про-

система диспетчеризации горнотранспортного оборудования [8];

- постоянный мониторинг состояния аэрогазовой среды в подземных горных выработках шахт осуществляет Единая диспетчерская служба [10];

- для осуществления контроля за выдачей нарядов на производство работ и за проведением инструктажей в режиме «online» на нарядных участках, а также для осуществления непрерывного производственного контроля за ведением горных работ, зонами ремонтов и ТО на предприятиях компании установлено более 250 видеокамер.

\section{КАДРОВЫЙ ВОПРОС}

Решение задач в области кадровой политики $[2,11]$ позволило улучшить состояние промышленной безопасности и охраны труда в 2017 г. и стимулировать работников на безопасный труд.

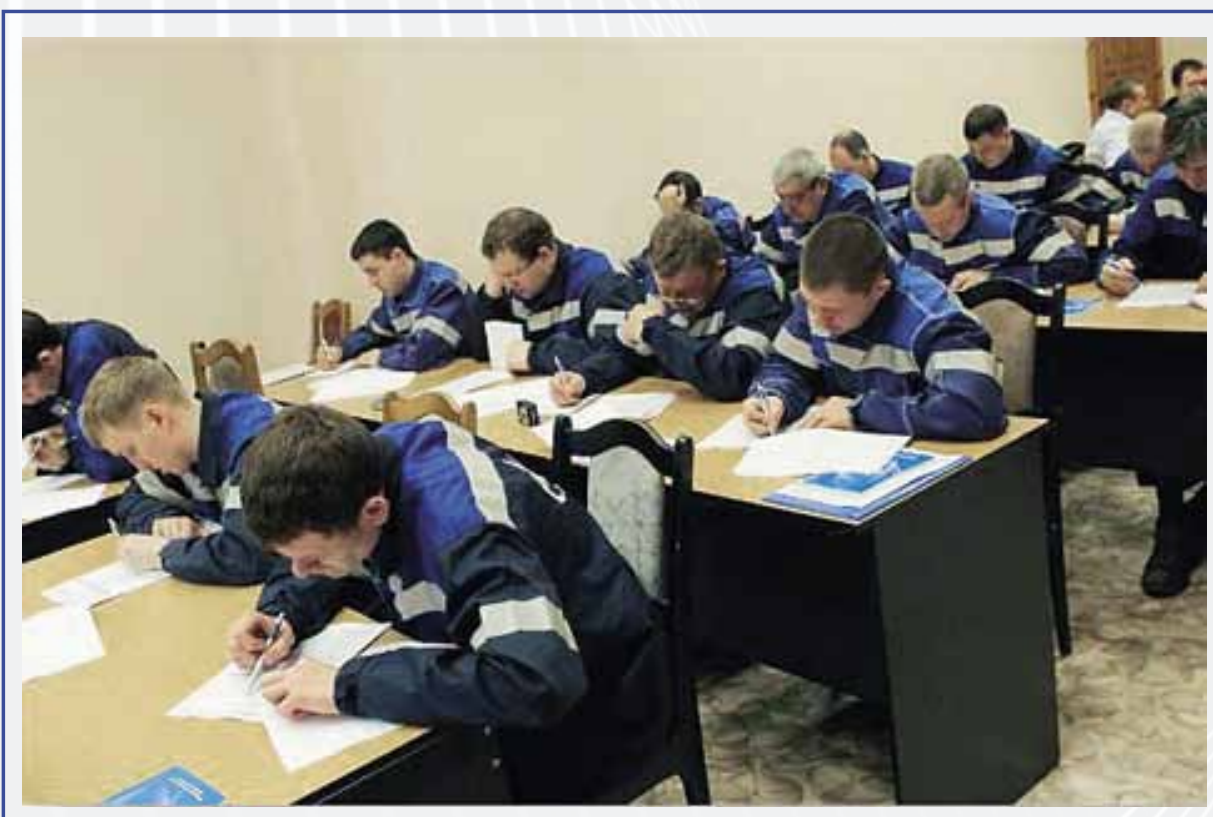

Puс. 2. Проверка знаний и аттестация в области промышленной безопасности изводственные показатели и не допускающих нарушения требований ПБ и ОТ, аварий, инцидентов и несчастных случаев, за счет экономии ФОТ от снижения размера премии за нарушения норм и правил ПБ и ОТ.

В 2017 г. обучение, проверку знаний и аттестацию в области промышленной безопасности прошли 569 PCС; повысили свою квалификацию 2558 рабочих; переобучено на новые (вторые) профессии 697 чел.; проверено знаний требований безопасности и инструкций по охране труда у 10159 чел.; целевое обучение в высших учебных заведениях проходят 26 чел. (рис. 2).

Ежеквартально в АО ХК «СДС-Уголь» и ежемесячно на предприятиях компании проводятся «Дни безопасности», которые включают в себя: техническую учебу, заседание постоянно действующей комиссии (ПДК), на которой проводят разбор действий нарушителей требований ПБ и ОТ. В 2017 г. на предприятиях отраслевого холдинга проведено 134 заседания «День безопасности».

По итогам заседаний ПДК работники, допустившие нарушения требований Правил промышленной безопасности и охраны труда, привлекались к ответственности. За 2017 г. привлечено к ответственности 1194 работника (2015 г. 2288 работников, 2016 г. - 1745 работников).

Выполнение решений заседаний ПДК и исполнение мероприятий, направленных на улучшение ПБ и ОТ, позволили снизить в 2017 г., по сравнению с 2016 г.:

- количество нарушений требований безопасности, выявленных службами ПК предприятий и холдинговой компании - на 39\%;

- количество случаев приостановки ведения работ специалиста- 
ми предприятий и холдинговой компании - на 48\%;

- количество инцидентов - на 14\%.

На предприятиях ХК «СДС-Уголь» внедрена и функционирует программа «Предсменного тестирования персонала» для проверки у работников уровня знаний требований промышленной безопасности и охраны труда по профессиям (рис. 3).

В 2018 г. в АО «Черниговец» для проведения предсменных и послесменных медицинских осмотров работников будут приобретены и установлены 23 системы «Диагностический шлюз».

На мониторах, установленных на предприятиях, производится систематическая трансляция видеофильмов, созданныхпо результатам расследования несчастных случаев, и фотографий нарушителей с указанием нарушенных ими пунктов правил, инструкций по охране труда.

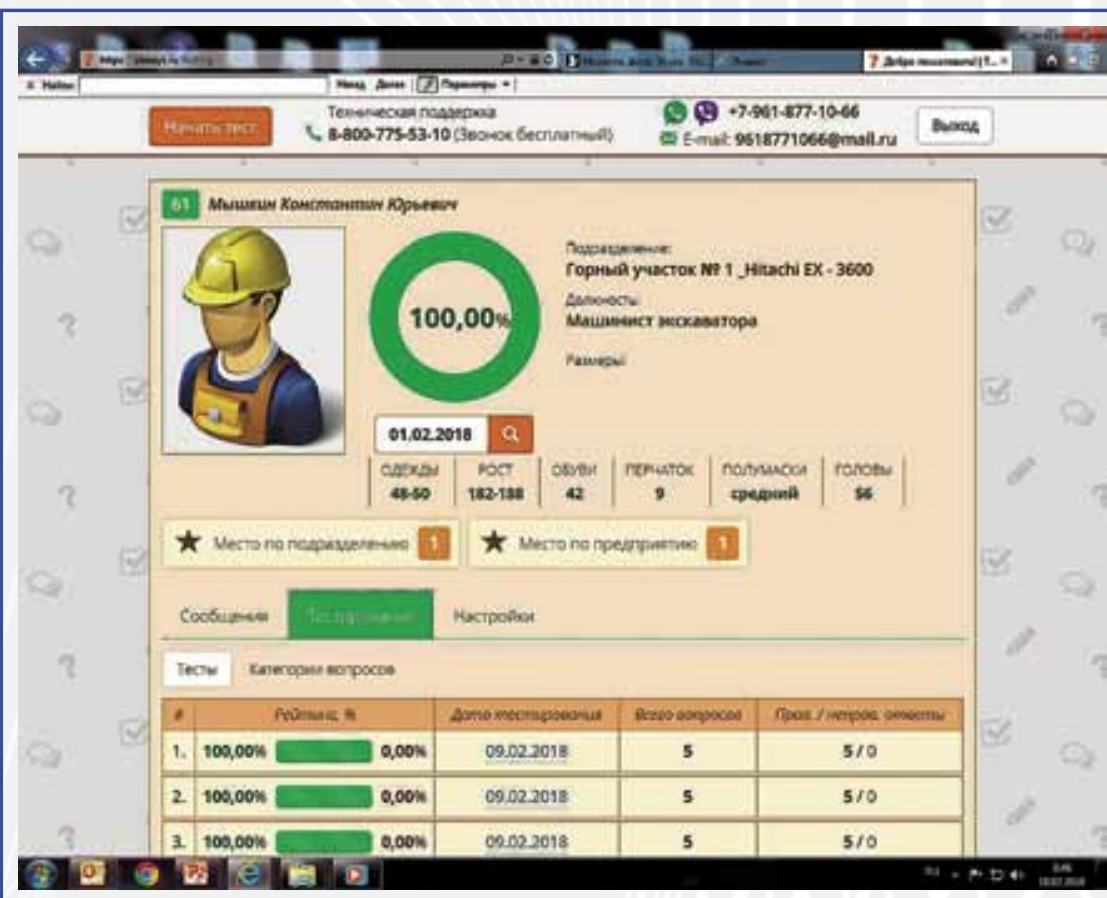

Рис. 3. Программа предсменного тестирования персонала

\section{ИННОВАЦИОННЫЕ ПРОЕКТЫ}

В 2018 г. планируются разработка и внедрение нескольких инновационных проектов на предприятиях ХК «СДСУголь», направленных на повышение уровня производственного контроля и охраны труда. Среди них установка систем видеонаблюдения в подземных горных выработках шахт для дистанционного контроля технологических процессов и персонала.

Кроме того, будет продолжено внедрение на предприятиях подземной добычи угля - в ООО «Шахта Листвяжная» и Шахта «Южная» (филиале $\mathrm{AO}$ «Черниговец») - разработанных проектов многофункциональных систем безопасности (МФСБ), которые прошли Главгосэкспертизу. На предприятияхоткрытых горных работ:внедрение системы высокоточного позиционирования буровых станков; внедрение системы удаленного мониторинга технического состояния карьерного оборудования для контроля его состояния и безаварийной работы, своевременного проведения ремонтов и ТО.

С целью обеспечения требований промышленной безопасности при формировании сменных нарядов на производство работ продолжится реализация проекта «Программный комплекс «Единая книга предписаний и формирования сменных нарядов» на предприятиях компании. Завершено внедрение на предприятиях холдинга «СДС-Уголь» «Единой базы экспертиз технических устройств, зданий и сооружений».

В 2018 г. также продолжится работа по установке в салонах автомобилей, используемых для перевозки трудящихся, систем видеотрансляции информации по охране труда и промышленной безопасности. С целью повышения эффективности осуществляемого непрерывного производственного контроля и динамической оптимизации маршрутов горнотранспортное оборудование (бульдозеры, автосамосвалы большой грузоподъемности, экскаваторы, грейдеры) будут оборудованы системами видеонаблюдения, обеспечивающими запись и хранение информации. Для осуществления мониторинга ведения горных работ планируется использовать беспилотные комплексы.

\section{ЗАКЛЮЧЕНИЕ}

В 2018 г. АО ХК «СДС-Уголь» продолжит дальнейшую модернизацию и замену морально устаревшего и физически изношенного оборудования, обеспечение роста добычи угля на предприятиях холдинга во многом за счет инновационных подходов и внедрения наилучших доступных технологий, сохраняя лидирующие позиции среди угольных компаний России. При этом важнейшими условиями устойчивого роста объемов производства остаются прежде всего промышленная иэкологическая безопасность [12] и социальная ответственность.

\section{Список литературы}

1. Рыбак Л.В. Знакомьтесь: ОАО Холдинговая компания «СДС-Уголь» // Уголь. 2007. № 8. С. 16-19. URL: http://www. ugolinfo.ru/Free/082007.pdf (дата обращения: 15.03.2018).

2. Ефимов В.И., Рыбак Л.В. Управление персоналом: учебное пособие. М., 2009.

3. Ефимов В.И.Управление качеством:учебное пособие / Под ред. Е.Ю. Граве. М., 2014.

4. Оценка уровня промышленной безопасности угольной промышленности и технического состояния отечественного горного оборудования / В.И. Ефимов, В.И. Панарин, В.А. Фатуев, А.Е. Пушкарев // Известия Тульского государственногоуниверситета. Науки о Земле. 2017. № 4. С. 121-130.

5. Поляков Ю.И., Ефимов В.И. Физика уровней охраны труда: Монография. Кемерово, 2001.

6. Баскаков В.П., Ефимов В.И., Сенаторов Г.В.Оценка рисков аварий, инцидентов и несчастных случаев. Планы управления безопасностью труда // Известия Тульского государственного университета. Науки о Земле. 2011. № 1. С. 22-35.

7. Баскаков В.П., Ефимов В.И., Сенаторов Г.В. Формирование системы управления охраной труда и промышленной безопасностью на основе управления рисками // Безопасность труда в промышленности. 2008. № 9. С. 60-64.

8. Совершенствование системы организации работы горнотранспортного оборудования на предприяти- 
ях открытой угледобычи АО ХК «СДС-Уголь» / Л.В. Рыбак, Ю.С. Дерябин, С.В. Бурцев, В.Е. Стихуров // Уголь. 2016. № 4. C. 14-19. URL: http://www.ugolinfo.ru/Free/042016.pdf (дата обращения: 15.03.2018).

9. Бурцев С.В., Морозова Т.А., Немченко А.А. Промышленные испытания систем мониторинга устойчивости бортов на разрезе «Черниговец» // Уголь. 2016. № 12. С. 7-13. URL: http://www.ugolinfo.ru/Free/122016.pdf (дата обращения: 15.03.2018).

10. Баскаков В.П., Ефимов В.И., Якимов М.Н. Многофункциональная система безопасности на шахтах ОАО ХК «СДСУголь» / «Энергоэффективность экономики и экологическая безопасность: теория и практика». VII Всерос. семи- нар ВУЗов по теплофизике и энергетике: сб. научн. статей. Кемерово, февраль 2012. С. 24-29.

11. Ефимов В.И.,Попов С.М., Федяев П.М.Методические основы организации подготовки кадров сучетом перспектив инновационного развития угольной отрасли. В сборнике:Повышение качества образования, современные инновации в науке и производстве / Сборник трудов Международной научнопрактической конференции. Прокопьевск, 2015. С. 122-124.

12. Обеспечение экологической безопасности при комплексном освоении угольных и техногенных месторождений / В.И. Ефимов, В.Л. Рыбак, Е.К. Мосина и др. // Экономика XXI века: инновации, инвестиции, образование. 2016. T. 4. № 1. С. 46-53.

UDC 622.8:622.33.012«SBU-Coal» @ S.V. Burtsev, O.Ph. Basyrov, 2018

ISSN 0041-5790 (Print) • ISSN 2412-8333 (Online) • Ugol' - Russian Coal Journal, 2018, № 4, pp. 26-30

\section{Title}

\section{INTEGRATED APPROACH IN THE FIELD OF INDUSTRIAL SAFETY AND LABOUR PROTECTION}

DOI: http://dx.doi.org/10.18796/0041-5790-2018-4-26-30

\section{Authors}

Burtsev S.V.', Basyrov O.Ph.'

1"SBU-Coal" Holding Company JSC, Kemerovo, 650066, Russian Federation

\section{Authors' Information}

Burtsev S.V., PhD (Economic), First Deputy General Director, Technical Director, e-mail: s.burtsev@sds-ugol.ru

Basyrov O.Ph., Deputy General Director for Production Control and Labour Safety, e-mail: o.basyrov@sds-ugol.ru

\section{Abstract}

The paper describes "SBU-Coal"Holding Company successes in improvement of industrial safety and labour protection, creation and implementation of the "Comprehensive program of improvement of industrial safety and labour protection level at the enterprises of "SBU-Coal" Holding Company JSC for the period of 2018 to $2020 . "$

\section{Keywords}

"SBU-Coal" Holding Company, Industrial safety, Labour protection, Hazardous production facilities, Systematic approach, Comprehensive program, Personnel issue, Innovative projects.

\section{References}

1. Rybak L.V. Znakom'tes': OAO Kholdingovaya kompaniya "SDS-Ugol"' [Get acquainted:"SBU-Coal"Holding Company OJSC]. Ugol'-Russian Coal Journal, 2007, No. 8, p. 16-19. Available at: http://www.ugolinfo.ru/Free/082007.pdf (accessed 15.03.2018).

2. Efimov V.I.\&Rybak L.V. Upravlenie personalom: Uchebnoe posobie [Personnel management. Educational aid.]. Moscow, 2009.

3. Efimov V.I. Upravlenie kachestvom: Uchebnoe posobie [Quality management: Educational aid.]. Under editorship of Grave E.Yu. Moscow, 2014.

4. Efimov V.I., Panarin V.I., Fatuev V.A. \& Pushkarev A.E. Otsenka urovnya promyshlennoy bezopasnosti ugol'noy promyshlennosti i tekhnicheskogo sostoyaniya otechestvennogo gornogo oborudovaniya [Evaluation of the level of industrial safety of the coal industry and technical condition of domestic mining equipment]. Izvestiya Tul'skogo gosudarstvennogo universiteta Nauki o Zemle - Bulletin of the Tula State University. Earth Sciences, 2017, No. 4, pp. 121-130.

5. Polyakov Yu.I. \& Efimov V.I. Fizika urovney okhrany truda: Monografiya [Physics levels of labour protection: Monograph]. Kemerovo, 2001.

6. Baskakov V.P., Efimov V.I. \& Senatorov G.V. Otsenka riskov avariy, intsidentov neschastnykh sluchaev. Plany upravleniya bezopasnost'yu truda [Assessment of accident, incidents and injury risks. Labour safety management plans] Izvestiya Tul'skogo gosudarstvennogo universiteta. Nauki o Zemle - Bulletin of the Tula State University. Earth Sciences, 2011, No. 1, pp. 22-35.

7. Baskakov V.P., Efimov V.I. \& Senatorov G.V. Formirovanie sistemy upravleniya okhranoy truda i promyshlennoy bezopasnost'yu na osnove upravleniya riskami [Formation of the labour safety and industrial safety management system based on risk management]. Bezopasnost truda $v$ promyshlennosti Industrial labour safety, 2008, No. 9, pp. 60-64.

8. Rybak L.V., Deryabin Yu.S., Burtsev S.V. \& Stihurov V.E. Sovershenstvovanie sistemy organizatsii raboty gornotransportnogo oborudovaniya na predpriyatiyakh otkrytoy ugledobychi AO KhK"SDS-Ugol"' [Mining and conveyor equipment operation organization improvement in "SBU-Coal", Holding Company OJSC open-pit mining enterprises]. Ugol' - Russian Coal Journal, 2016, No. 4, pp. 14-19. doi 10.18796/0041-5790-2016-4-14-19. Available at: http:// www.ugolinfo.ru/Free/042016.pdf (accessed 15.03.2018).

9. Burtsev S.V., Morozova T.A. \& Nemchenko A.A. Promyshlennye ispytaniya sistem monitoringa ustoychivosti bortov na razreze "Chernigovets" ["Chernigovets" open-pit mine slopes stability monitoring systems production testing]. Ugol' - Russian Coal Journal, 2016, No. 12, pp. 7-13. Available at: http://www.ugolinfo.ru/Free/122016.pdf (accessed 15.03.2018).

10. Baskakov V.P., Efimov V.I. \& Yakimov M.N. Mnogofunktsional'naya sistema bezopasnosti na shakhtakh OAO KhK "SDS-Ugol"' [Multifunctional safety system at mines of OJSC KhK "SDS-Ugol"]. "Energoeffektivnost' ekonomiki i ekologicheskaya bezopasnost': teoriya i praktika". VII Vseros. seminar VUZov po teplofizike i energetike: sb. nauchn. Statey [«Energy Efficiency of the Economy and Environmental Safety: Theory and Practice». VII AllRussian Seminar of Higher Educational Establishments in Thermophysics and Energy: collection of scientific articles]. Kemerovo, February 2012, pp. 24-29.

11. Efimov V.I., Popov S.M. \& Fedyaev P.M. Metodicheskie osnovy organizacil podgotovki kadrov s uchetom perspektiv innovacionnogo razvitiya ugol'noj otrasli [Methodical principles of company personnel training with account for the coal industry innovative development]. In the collection of articles: Povyshenie kachestva obrazovaniya, sovremennye innovacii v nauke i proizvodstve [Eduction quality improvement, modern innovations in production]. Sbornik trudov Mezhdunarodnoj nauchno-prakticheskoj konferencii [Collection of international scientific and practical conference essays]. Prokop'evsk, KuzSTU branch Publ., 2015, pp. 122-124.

12. Efimov V.I., Rybak V.L., Mosina E.K. et al. Obespechenie ekologicheskoy bezopasnosti pri kompleksnom osvoenii ugol'nykh i tekhnogennykh mestorozhdeniy [Ensuring environmental safety during integrated development of coal and technogenic fields]. Ekonomika XXI veka: innovatsii, investitsii, obrazovanie-Economics of the 21 th century: innovation, investment, education, 2016, Vol. 4, No. 1, pp. 46-53. 


\section{Основной путь ликвидации взрывов метана в высоконагруженных очистных забоях} угольных шахт, опасных по газу, предупреждение создания взрывоопасной метановоздушной смеси

DOI: http://dx.doi.org/10.18796/0041-5790-2018-4-31-35

В статье освещается основная тенденция ликвидации взрывов метана в очистных забоях сверхкатегорных угольных шахт - повышение эффективности превентивных мер по исключению взрывоопасных концентраций газа метана в очистных забоях при интенсификации добычи. Основными факторами, формирующими взрывоопасную концентрацию газовоздушной смеси в очистном забое, определены: абсолютное метановыделение и относительная метанообильность при добыче, интенсивность работы очистного комбайна при резании угля. В статье приведена методика определения массовой доли метана (и в процентах) при учете различных вариантов относительной метанообильности, интенсивности работы очистного комбайна и коэффициента десорбции метана. Доказывается концептуальная основа метанобезопасности на угольных шахтах, предполагающая систему превентивных мер предупреждения формирования взрывоопасной метановоздушной смеси в забоях, на основе организационно-технологического регулирования метановыделением и интенсивностью операций добычного цикла.

Ключевые слова:метаноопасность, взрывоопасныеконцентрации метана, массовая доля газа, превентивные меры безопасности, организационно-технологическое регулирование, система превентивных мер.

\section{ВВЕДЕНИЕ В ПРОБЛЕМАТИКУ}

\section{МЕТАНООПАСНОСТИ УГОЛЬНЫХ ПЛАСТОВ}

Согласно результатам работы угольной промышленности России среднесуточная нагрузка на комплексномеханизированный забой по итогам работы за 2016 г. достигла 4867 т [1, 2], при этом в сентябре 2016 г. на двух шахтах АО «СУЭК-Кузбасс» «Талдинская-Западная - 1» и им. В.Д. Ялевского преодолен рубеж месячной добычи угля из одного очистного забоя в один миллион тонн. А в 2017 г. в мае и июле бригада Евгения Косьмина на шахте им. В.Д. Ялевского дважды обновляла российский рекорд месячной добычи, выдав на-гора соответственно 1 млн 407 тыс. т и 1 млн 567 тыс. т, последний результат является также лучшим показателем и для мировой угольной отрасли [3].

Данные результаты доказывают повышенную интенсификацию добычи угля в очистном забое до 46900 т/сут и

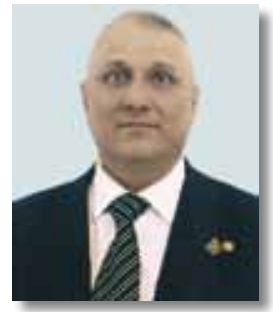

НОВОСЕЛОВ
Сергей Вениаминович

Канд. экон. наук, дочент кафедры

«Экономической безопасности

и менеджмента»

филиала КузГТУ в г. Белово,

652644 , г. Белово, Россия,

тел.: +7 (950) 273-31-86,

e-mail:nowosyolow.sergej@yandex.ru

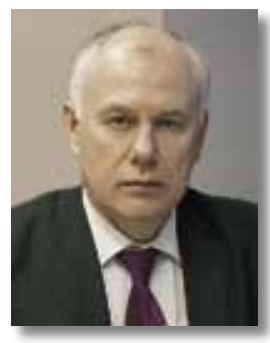

\section{ПАНИХИДНИКОВ}

\section{Сергей Александрович}

Канд. воен. наук,

заведующий кафедрой экологии и БЖД СПб ГУТ им. проф. М.А. Бонч-Бруевича, 193232, г. Санкт-Петербург, Россия, тел.: +7 (911) 985-17-28, e-mail:panihidnikov@mail.ru

более (скорость комбайна при выемке - 20 м/мин, а при зачистке - 30 м/мин). Понятно, что достичь таких рекордных показателей без эффективной организационной работы (технологической, безопасности) невозможно. Следует отметить важный факт дегазации, коэффициент эффективности дегазации был равным 0,5, обычно этот показатель едва превышает значение 0,3 , при этом природная метаноносность разрабатываемых пластов составляла в первом случае $2,56 \mathrm{~m}^{3} / \mathrm{T}$, а на второй шахте $-8,5 \mathrm{~m}^{3} / \mathrm{T}$.

Из всех газов, выделяющихся в шахте из угольных пластов и пород самым опасным является газ метан, так как аварии, связанные со взрывами газа метана несут, как правило, групповые смертельные случаи. С конца 1970-х гг. в СССР и в России по настоящее время произошел ряд крупных аварий, связанных со взрывами газа метана с многочисленными жертвами. Так, в 1978 г. на шахте «Сокурская» (СССР) погибли 72 горняка, в 2007 г. на шахте «Улья- 
новская» погибли 110 человек, в 2010 г. на шахте «Распадская» - 91 человек, в 2016 г. на шахте «Северная» (Республика Коми) - 36 человек [5, с. 34]. Газ метан - «коварный», «скрытый» и «опасный враг» для шахтера, так как обладает именно такими свойствами. Метан - газ без цвета и за-

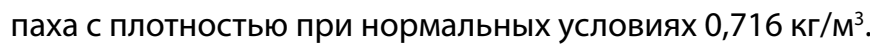
При содержании в воздухе до 4-6\% горит почти бесцветным пламенем. Взрывается при объемной концентрации в воздухе от 4,9 до 15,4\%. Наиболее легковоспламеняемая объемная доля (концентрация) - 8\%. Наибольшей силы взрыв метана достигает при объемной доле, равной 9,5\%.

Принимаемые меры борьбы со взрывами в виде сланцевых и водяных заслонов, перемычек и всевозможных завес и других искусственных сооружений, воздвигаемых на пути взрывной волны, эффективного действия не имеют, это доказывают согнутые после взрыва в шахте рельсы, порванные противопожарные ставы и поврежденные копры шахт на поверхности.

Поэтому авторы видят основной путь ликвидации взрывов метана в высоконагруженных очистных забоях угольных шахт, опасных по газу, в недопущении создания в них взрывоопасной метановоздушной смеси. В принципе, взрыв метана возможен только при совместном появлении двух причин: наличие взрывчатой метановоздушной смеси и возникновения открытого огня, искры, дуги или температуры воспламенения метана $650-750^{\circ} \mathrm{C}$. Увеличение температуры ведет к уменьшению нижнего предела взрывчатости метановоздушной смеси. При температуре $400^{\circ} \mathrm{C}$ этот предел равен 3\%. При насыщении метановоздушной смеси водяными парами предел ее взрывчатости снижается. Наличие диоксида углерода также снижает верхний предел взрывчатости. Увеличение запыленности шахтной атмосферы с 5 до 30 г/м ${ }^{3}$ уменьшает нижний предел взрывчатости с 3 до 0,5\%. При этом энергия воспламенения пылегазовой смеси увеличивается в 100-300 раз по сравнению с метановоздушной смесью.

Интенсивность метановыделения из угольных пластов и пород определяется газоносностью, давлением и температурой, а также проницаемостью, пористостью, газоотдающей способностью, газоемкостью угля или породы, строением пласта и технологией ведения горных работ.

Высокая газоносность угольных пластов повышает риск взрыва метана, она зависит от глубины их залегания, степени метаморфизма и тектонической нарушенности, приуроченности к определенным геологическим структурам и может достигать 40-45 м³ на 1 т горючей массы.

Согласно Правилам безопасности [6, с. 91], в зависимости от величины относительной метанообильности и вида выделения метана газовые шахты разделяются на пять категорий (табл.1).

\section{Классификац \\ Категория шах по метану I II III}

Сверхкатегорные Опасные

по внезапным выбросам
Таблича 1

\begin{tabular}{|c|}
\hline $\begin{array}{c}\text { Относительная } \\
\text { метанообильность, м³/т }\end{array}$ \\
\hline до 5 \\
\hline от 5 до 10 \\
\hline от 10 до 15 \\
\hline 15 и более, суфлярные выделения \\
\hline $\begin{array}{c}\text { Пласты, опасные по внезапным } \\
\text { выбросам угля и газа, } \\
\text { а также выбросоопасные породы }\end{array}$ \\
\hline
\end{tabular}

На основе данных табл. 1 можно априори рассчитать опасные технологические параметры ведения очистных работ в условиях интенсификации добычи угля для шахт различных категорий.

\section{МЕТОД ОПРЕДЕЛЕНИЯ МАССОВОЙ ДОЛИ МЕТАНА}

\section{В МЕТАНОВОЗДУШНОЙ СМЕСИ ОЧИСТНОГО ЗАБОЯ}

Авторы предлагают проведение предварительных, а далее, в процессе исследования, уточненных расчетов абсолютного метановыделения $\left(J, \mathrm{M}^{3} / \mathrm{Mин}\right)$ из угольного пласта очистного забоя и определять расчетную концентрацию метана в метаноздушной смеси, так как приборами замерить в момент резания угля фактическую концентрацию в наиболее опасном месте, у кровли очистного забоя, где происходит соприкосновение зубцов шнека комбайна и угольного пласта во время резания, невозможно.

Поэтому, исходя из фактических нагрузок на очистные забои, необходимо проводить физико-технологический расчет метановыделения на мощных пластах шахт II, III категории и сверхкатегорных, исходя из следующих данных: мощность $m>3,5$ м, относительная метанообиль-

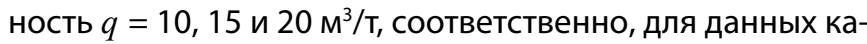
тегорий шахт, среднем удельном весе угля $\gamma=1,34$ т/ $\mathrm{M}^{3}$, при пределах коэффициента десорбции метана из угля $k=20-80 \%$, с учетом ширины захвата комбайна 1000 мм, при максимальных линейных скоростях очистного комбайна $l=20-36 \mathrm{~m} /$ мин.

Расчеты проведем по следующему алгоритму.

Параметры абсолютного метановыделения J газа метана в части очистного забоя за минуту определяются по формуле:

$$
J_{l}=m \cdot l \cdot \gamma \cdot q \cdot k
$$

Количество вещества в молях $n$ в объеме газов смеси метана и воздуха, при учете, что 1 моль газа равен 22,4 л, определяется по формуле:

$$
n(\mathrm{~B})=\frac{V(\mathrm{~B})}{V_{n}},
$$

где $V(\mathrm{~B})$ - объем газа, л; $V_{n}$ - молярный объем любого газа (22,4 л).

Поступление метана в очистной забой в молях составит: $n\left(\mathrm{CH}_{4}\right)_{I}=(J \cdot 1000) / 22,4$ (моль).

Поступление воздуха в очистной забой при максимальной скорости воздушной струи (в молях) определяется по формуле:

$$
n(\mathrm{~B})=\frac{S \cdot v_{\max } \cdot t \cdot 1000}{22,4} .
$$

Масса газов $m($ г) в очистном забое с учетом количества молей газов и молярной массы $M$ определяется по формуле:

$$
\begin{aligned}
& m\left(\mathrm{CH}_{4}\right)=n\left(\mathrm{CH}_{4}\right) \cdot M_{\mathrm{CH}_{4}}, \\
& M_{\mathrm{CH}_{4}}=16 \text { г/моль }
\end{aligned}
$$

Масса воздуха с учетом количества молей газов и молярной массы определяется по формуле:

$$
\begin{aligned}
& m_{\text {в }}=n(\mathrm{~B}) \cdot M_{\text {возд.' }} \\
& M_{\text {возд. }}=29 \text { г/моль }
\end{aligned}
$$

Массовая доля метана в смеси метана и воздуха определяется по формуле:

$$
\omega\left(\mathrm{CH}_{4}\right)=\frac{m\left(\mathrm{CH}_{4}\right)}{m\left(\mathrm{CH}_{4}\right)+m_{\text {в. }}},
$$


Поэтапные расчеты варьирования регулируемых величин и полученные в результате массовые доли (концентрации) метана в метановоздушной смеси приведены в табл. 2, 3, 4, 5.

Анализируя вышеприведенные таблицы, можно сделать вывод, что при линейных скоростях 10 м/мин и коэффициенте десорбции порядка 0,1 очевидна безопасная добыча угля в пределах более 10000 тыс. т/сут, если же повысить эффективность предварительной дегазации до 0,5 от относительной метанообильности $(q), \mathrm{M}^{3} / \mathrm{T}$, будем иметь уменьшенную концентрацию метана как минимум в 2 раза, т.е. при рассчитанных диапазонах 1,5-9,9\% и относительной метанообильности $q=10 \mathrm{~m}^{3} /$, большей, чем в рассматриваемых выше забоях-рекордсменах (в 1,2-4 раза), получим 0,4-2,7\% метана, что реально вписывается в требования ПБ.
Но и это еще не предел по минимизации концентрации метановоздушной смеси, так как можно применить и гидроразрыв пласта, и другие комплексные меры дегазации, комбинированные схемы проветривания и т.п.

\section{ЗАКЛЮЧЕНИЕ}

Радикальное обеспечение метанобезопасности на угольных шахтах Кузбасса опасных по газу возможно только исключением создания взрывоопасной метановоздушной смеси в высоконагруженных очистных забоях. Основные меры: научные исследования и расчеты возможных концентраций метановоздушных смесей, комплексная дегазация (предварительная с поверхности и в ходе работы, если требуется бурение скважин со штреков, и гидроразрывы), оптимизация режимов проветривания и интенсивности резания угля комбайном, влияющего на десорбцию метана.

Таблича 2

Расчет абсолютного метановыделения в очистном забое $J$ при варьировании $l$ и $k$

\begin{tabular}{|c|c|c|c|c|c|}
\hline $\begin{array}{c}\text { Мощность } \\
\text { пласта } m, \\
\text { м }\end{array}$ & $\begin{array}{c}\text { Скорость } \\
\text { (линейный путь) } \\
\text { комбайна } \\
\text { l, м/мин }\end{array}$ & $\begin{array}{c}\text { Средний } \\
\text { удельный вес } \\
\text { угля } \gamma, \mathbf{T} / \mathbf{m}^{3}\end{array}$ & $\begin{array}{c}\text { Относительная } \\
\text { метанообильность } q \text {, } \\
\text { м³/т }\end{array}$ & $\begin{array}{c}\text { Коэффициент } \\
\text { десорбции метана } \\
\text { из угля } k\end{array}$ & $\begin{array}{c}\text { Абсолютное } \\
\text { метановыделение } \\
\text { в очистном забое } J \text {, } \\
\text { м³/мин }\end{array}$ \\
\hline 5 & 36 & 1,34 & 5 & 0,2 & 241,2 \\
\hline 5 & 30 & 1,34 & 5 & 0,2 & 201 \\
\hline 5 & 25 & 1,34 & 5 & 0,2 & 167,5 \\
\hline 5 & 20 & 1,34 & 5 & 0,2 & 134 \\
\hline 5 & 15 & 1,34 & 5 & 0,2 & 100,5 \\
\hline 5 & 10 & 1,34 & 5 & 0,2 & 67 \\
\hline 5 & 10 & 1,34 & 5 & 0,19 & 63,65 \\
\hline 5 & 10 & 1,34 & 5 & 0,18 & 60,3 \\
\hline 5 & 10 & 1,34 & 5 & 0,17 & 56,95 \\
\hline 5 & 10 & 1,34 & 5 & 0,16 & 53,6 \\
\hline 5 & 10 & 1,34 & 5 & 0,15 & 50,25 \\
\hline 5 & 10 & 1,34 & 5 & 0,1 & 33,5 \\
\hline 5 & 15 & 1,34 & 5 & 0,1 & 50,25 \\
\hline 5 & 20 & 1,34 & 5 & 0,1 & 67 \\
\hline 5 & 25 & 1,34 & 5 & 0,1 & 83,75 \\
\hline 5 & 36 & 1,34 & 5 & 0,1 & 120,6 \\
\hline
\end{tabular}

Таблица 3

Расчет количества вещества в молях $\boldsymbol{n}$ в объеме газов смеси - метана и воздуха в очистном забое за минуту $n\left(\mathrm{CH}_{4}\right)$ и $n($ в) при варьировании $l$ и $k$

\begin{tabular}{|c|c|c|c|c|c|c|}
\hline $\begin{array}{c}\text { Площадь } \\
\text { поперечного } \\
\text { сечения забоя } S, \mathbf{m}^{2}\end{array}$ & $\begin{array}{c}\text { Скорость } \\
\text { вентиляционной } \\
\text { струи } v, \mathbf{m} / \mathbf{c} \\
\end{array}$ & Время $t, \mathbf{C}$ & $\begin{array}{c}\text { Переводной } \\
\text { коэффициент } \\
\text { куб. м - литры }\end{array}$ & $\begin{array}{c}\text { Параметр } \\
1 \text { моль, л }\end{array}$ & $\begin{array}{c}\text { Количество } \\
\text { вещества метана } \\
n\left(\mathrm{CH}_{4}\right) \text {, моль }\end{array}$ & $\begin{array}{c}\text { Количество } \\
\text { вещества } \\
\text { воздуха } n(\text { в), моль }\end{array}$ \\
\hline 10 & 4 & 60 & 1000 & 22,4 & 10767,86 & 107142,9 \\
\hline 10 & 4 & 60 & 1000 & 22,4 & 8973,214 & 107142,9 \\
\hline 10 & 4 & 60 & 1000 & 22,4 & 7477,679 & 107142,9 \\
\hline 10 & 4 & 60 & 1000 & 22,4 & 5982,143 & 107142,9 \\
\hline 10 & 4 & 60 & 1000 & 22,4 & 4486,607 & 107142,9 \\
\hline 10 & 4 & 60 & 1000 & 22,4 & 2991,071 & 107142,9 \\
\hline 10 & 4 & 60 & 1000 & 22,4 & 2841,518 & 107142,9 \\
\hline 10 & 4 & 60 & 1000 & 22,4 & 2691,964 & 107142,9 \\
\hline 10 & 4 & 60 & 1000 & 22,4 & 2542,411 & 107142,9 \\
\hline 10 & 4 & 60 & 1000 & 22,4 & 2392,857 & 107142,9 \\
\hline 10 & 4 & 60 & 1000 & 22,4 & 2243,304 & 107142,9 \\
\hline 10 & 4 & 60 & 1000 & 22,4 & 1495,536 & 107142,9 \\
\hline 10 & 4 & 60 & 1000 & 22,4 & 2243,304 & 107142,9 \\
\hline 10 & 4 & 60 & 1000 & 22,4 & 2991,071 & 107142,9 \\
\hline 10 & 4 & 60 & 1000 & 22,4 & 3738,839 & 107142,9 \\
\hline 10 & 4 & 60 & 1000 & 22,4 & 5383,929 & 107142,9 \\
\hline
\end{tabular}


Расчет массовой доли метана в смеси метана и воздуха при относительной метанообильности при варьировании $l$ и $k$

\begin{tabular}{|c|c|c|c|c|c|}
\hline \multicolumn{3}{|c|}{ Относительная метанообильность $q=5$ м³/т } & \multicolumn{3}{|c|}{ Относительная метанообильность $q=10 \mathrm{~m}^{3} / \mathrm{\tau}$} \\
\hline $\begin{array}{c}\text { Масса метана в } \\
\text { рассматриваемом } \\
\text { объеме } m\left(\mathrm{CH}_{4}\right), \mathbf{r}\end{array}$ & $\begin{array}{c}\text { Масса воздуха } \\
\text { в рассматриваемом } \\
\text { объеме } m(\mathrm{~B}), \mathbf{r}\end{array}$ & $\begin{array}{c}\text { Массовая доля } \\
\text { метана в смеси } \\
\omega, \%\end{array}$ & $\begin{array}{c}\text { Масса метана } \\
\text { в рассматриваемом } \\
\text { объеме } m\left(\mathrm{CH}_{4}\right), \mathbf{r}\end{array}$ & $\begin{array}{c}\text { Масса воздуха } \\
\text { в рассматриваемом } \\
\text { объеме } m(\mathrm{~B}), \mathbf{r}\end{array}$ & $\begin{array}{c}\text { Массовая доля } \\
\text { метана в смеси } \\
\omega, \%\end{array}$ \\
\hline 172285,7 & 3107143 & $0,052 / 5,2$ & 344571,4 & 3107143 & $0,099 / 9,9$ \\
\hline 143571,4 & 3107143 & $0,044 / 4,46$ & 287142,9 & 3107143 & $0,084 / 8,4$ \\
\hline 119642,9 & 3107143 & $0,037 / 3,7$ & 239285,7 & 3107143 & $0,071 / 7,1$ \\
\hline 95714,29 & 3107143 & $0,029 / 2,9$ & 191428,6 & 3107143 & $0,058 / 5,8$ \\
\hline 71785,71 & 3107143 & $0,022 / 2,2$ & 143571,4 & 3107143 & $0,044 / 4,4$ \\
\hline 47857,14 & 3107143 & $0,015 / 1,5$ & 95714,29 & 3107143 & $0,029 / 2,9$ \\
\hline 45464,29 & 3107143 & $0,014 / 1,4$ & 90928,57 & 3107143 & $0,028 / 2,8$ \\
\hline 43071,43 & 3107143 & $0,013 / 1,3$ & 86142,86 & 3107143 & $0,026 / 2,6$ \\
\hline 40678,57 & 3107143 & $0,012 / 1,2$ & 81357,14 & 3107143 & $0,025 / 2,5$ \\
\hline 38285,71 & 3107143 & $0,0121,2$ & 76571,43 & 3107143 & $0,024 / 2,4$ \\
\hline 35892,86 & 3107143 & $0,011 / 1,1$ & 71785,71 & 3107143 & $0,022 / 2,2$ \\
\hline 23928,57 & 3107143 & $0,007 / 0,7$ & 47857,14 & 3107143 & $0,015 / 1,5$ \\
\hline 35892,86 & 3107143 & $0,011 / 0,011$ & 71785,71 & 3107143 & $0,022 / 2,2$ \\
\hline 47857,14 & 3107143 & $0,015 / 1,15$ & 95714,29 & 3107143 & $0,029 / 2,9$ \\
\hline 59821,43 & 3107143 & $0,018 / 1,8$ & 119642,9 & 3107143 & $0,037 / 3,7$ \\
\hline 86142,86 & 3107143 & $0,026 / 2,6$ & 172285,7 & 3107143 & $0,052 / 5,2$ \\
\hline
\end{tabular}

Таблица 5

Расчет массовой доли метана в метановоздушной смеси при относительной метанообильности при варьировании $l$ и $k$

\begin{tabular}{|c|c|c|c|c|c|}
\hline \multicolumn{3}{|c|}{ Относительная метанообильность $q=15$ м³/т } & \multicolumn{3}{|c|}{ Относительная метанообильность $q=20$ м³/т } \\
\hline $\begin{array}{c}\text { Масса метана } \\
\text { в рассматриваемом } \\
\text { объеме } m\left(\mathrm{CH}_{4}\right), \mathbf{r}\end{array}$ & $\begin{array}{c}\text { Масса воздуха } \\
\text { в рассматриваемом } \\
\text { объеме } m(\mathrm{~B}), \mathbf{r}\end{array}$ & $\begin{array}{c}\text { Массовая доля } \\
\text { метана в смеси } \\
\omega, \%\end{array}$ & $\begin{array}{c}\text { Масса метана } \\
\text { в рассматриваемом } \\
\text { объеме } m\left(\mathrm{CH}_{4}\right), \mathbf{r}\end{array}$ & $\begin{array}{c}\text { Масса воздуха } \\
\text { в рассматриваемом } \\
\text { объеме } m(\mathrm{~B}), \mathbf{r}\end{array}$ & $\begin{array}{c}\text { Массовая доля } \\
\text { метана в смеси } \\
\omega, \%\end{array}$ \\
\hline 516857,1 & 3107143 & $0,14 / 14$ & 689142,9 & 3107143 & $0,18 / 18$ \\
\hline 430714,3 & 3107143 & $0,12 / 12$ & 574285,7 & 3107143 & $0,155 / 15,5$ \\
\hline 358928,6 & 3107143 & $0,10 / 10$ & 478571,4 & 3107143 & $0,133 / 13,3$ \\
\hline 287142,9 & 3107143 & $0,084 / 8,4$ & 382857,1 & 3107143 & $0,109 / 10,9$ \\
\hline 215357,1 & 3107143 & $0,064 / 6,4$ & 287142,9 & 3107143 & $0,084 / 8,4$ \\
\hline 143571,4 & 3107143 & $0,044 / 4,4$ & 191428,6 & 3107143 & $0,058 / 5,8$ \\
\hline 136392,9 & 3107143 & $0,042 / 4,2$ & 181857,1 & 3107143 & $0,055 / 5,5$ \\
\hline 129214,3 & 3107143 & $0,039 / 3,9$ & 172285,7 & 3107143 & $0,052 / 5,2$ \\
\hline 122035,7 & 3107143 & $0,037 / 3,7$ & 162714,3 & 3107143 & $0,049 / 4,9$ \\
\hline 114857,1 & 3107143 & $0,035 / 3,5$ & 153142,9 & 3107143 & $0,046 / 4,6$ \\
\hline 107678,6 & 3107143 & $0,033 / 3,3$ & 143571,4 & 3107143 & $0,044 / 4,4$ \\
\hline 71785,71 & 3107143 & $0,022 / 2,2$ & 95714,29 & 3107143 & $0,029 / 2,9$ \\
\hline 107678,6 & 3107143 & $0,033 / 3,3$ & 143571,4 & 3107143 & $0,044 / 4,4$ \\
\hline 143571,4 & 3107143 & $0,044 / 4,4$ & 191428,6 & 3107143 & $0,058 / 5,8$ \\
\hline 179464,3 & 3107143 & $0,054 / 5,4$ & 239285,7 & 3107143 & $0,071 / 7,1$ \\
\hline 258428,6 & 3107143 & $0,076 / 7,6$ & 344571,4 & 3107143 & $0,099 / 9,9$ \\
\hline
\end{tabular}

\section{Список литературы}

1. Таразанов И.Г. Итоги работы угольной промышленности России за январь-декабрь 2016 года // Уголь. 2017. № 3. C. 36-50. doi: 10.18796/0041-5790-2017-3-36-50. URL: http://www.ugolinfo.ru/Free/032017.pdf (дата обращения: 15.02.2018).

2. Яновский А.Б. Основные тенденции и перспективы развития угольной промышленности России //Уголь. 2017. № 8. C.10-14. doi: 10.18796/0041-5790-2017-8-10-14. URL: http://www.ugolinfo.ru/Free/082017.pdf (дата обращения: 15.02.2018).

3. Очередной рекорд в российской угледобывающей промышленности // Уголь. 2017. № 9. С.22-24. URL: http://www.ugolinfo.ru/Free/092017.pdf (дата обращения: 15.02.2018).
4. Достижение наивысших показателей по добыче угля в месяц в условиях АО «СУЭК-Кузбасс» / В.Б. Артемьев, Е.П. Ютяев, К.Н. Копылов и др. // Уголь. № 8. 2017. С. 82-88. URL: http://www.ugolinfo.ru/Free/082017.pdf (дата обращения: 15.02.2018).

5. Новоселов С.В., Панихидников С.А. Травматизм в угольной промышленности России и прогнозирование аварий взрыва метана на опасном производственном объекте в очистном забое сверхкатегорной шахты. // Уголь. № 9. 2017. C.32-35. URL: http://www.ugolinfo.ru/Free/092017.pdf (дата обращения: 15.02.2018).

6. Правила безопасности в угольных шахтах (ПБ 05-618-03). Серия 05. Выпуск 11. М.: ФГУП «Научнотехнический центр по безопасности в промышленности», 2005. 296 с. 
UDC 614.8:629.039.58 @ S.V. Novoselov, S.A. Panihidnikov, 2018

ISSN 0041-5790 (Print) • ISSN 2412-8333 (Online) • Ugol' - Russian Coal Journal, 2018, № 4, pp. 31-35

Title

THE PRIMARY PATHWAY FOR ELIMINATION OF METHANE EXPLOSIONS IN HIGHLY LONGWALL FACE OF COAL MINES DANGEROUS ON GAS - HAZARDOUS MININGS IS TO PREVENT THE CREATION OF AN EXPLOSIVE METHANE-AIR MIXTURE

DOI: http://dx.doi.org/10.18796/0041-5790-2018-4-31-35

\section{Authors}

Novoselov S.V. ${ }^{1}$, Panihidnikov S.A. ${ }^{2}$

${ }^{1}$ Branch Kuzbass State Technical University (KuzSTU), Belovo, 652644, Russian Federation

${ }^{2}$ Professor M.A. Bonch-Bruevich Saint-Petersburg State University of Telecommunications, Saint-Petersburg, 193232, Russian Federation

\section{Authors' Information}

Novoselov S.V., PhD (Economic), Associate Professor of Department

"Economic safety and Management", tel.: +7 (950) 273-31-86,

e-mail: nowosyolow.sergej@yandex.ru

Panihidnikov S.A., PhD (Military), Head of Department of Ecology and Life

Protection Sciences, tel.: +7 (911) 985-17-28, e-mail: panihidnikov@mail.ru

\section{Abstract}

The paper highlights the main trend of the elimination of methane explosions in Stopes sverhkategorijnye of coal mines - increase of efficiency of preventive measures to prevent explosive concentrations of methane gas in the mining faces at the intensification of production. The main factors of forming an explosive concentration of the gas mixture in a breakage face is defined: absolute and relative methane release metakaolinite during extrac tion, the intensity of the Shearer when cutting coal. The paper describes methods of determining the mass fraction of methane (in percent) based on different variants of relative metrobility, work intensity of the Shearer and the coefficient of desorption of methane. Proved the conceptual basis of metrobasement in coal mines involving the system of preventive measures to prevent the formation of explosive methane-air mixture in the faces, on the basis of the organizational-technological regulation by methane release, and activity of the mining cycle.

\section{Keywords}

Methane safety, Explosive concentrations of methane, Gas mass fraction, Safety preventive measures, Organizational and technological regulation, System of preventive measures.

\section{References}

1. Tarazanov I.G. Russia's coal industry performance for January - December, 2016. Ugol'- Russian Coal Journal, 2017, No. 3, pp. 36-50. doi: 10.18796/00415790-2017-3-36-50. Available at: http://www.ugolinfo.ru/Free/032017.pdf (accessed 15.02.2018).

2. Yanovsky A.B. Main trends and prospects of the coal industry development in Russia. Ugol' - Russian Coal Journal, 2017, No. 8, pp. 10-14. doi: 10.18796/0041-5790-2017-8-10-14. Available at: http://www.ugolinfo.ru/ Free/082017.pdf (accessed 15.02.2018).

3. Ocherednoy rekord $v$ rossiyskoy ugledobyvayushchey promyshlennosti [The next record of the Russian coal production industry]. Ugol' - Russian Coal Journal, 2017, No. 9, pp. 22-24. Available at: http://www.ugolinfo.ru/ Free/092017.pdf (accessed 15.02.2018).

4. Artemiev V.B., Yutyaev E.P., Kopylov K.N., Meshkov A.A., Demura V.N. \& Smirnov O.V. Dostizhenie naivysshikh pokazateley po dobyche uglya $v$ mesyats v usloviyakh AO «SUEK-Kuzbass» [Reaching top coal mining monthly production figures with "SUEK-Kuzbass", JSC]. Ugol' - Russian Coal Journal, 2017, No. 8, pp. 82-88. Available at: http://www.ugolinfo.ru/Free/082017. pdf (accessed 15.02.2018).

5. Novoselov S.V. \& Panihidnikov S.A. Travmatizm v ugol'noy promyshlennosti Rossii i prognozirovanie avariy vzryva metana na opasnom proizvodstvennom ob"ekte - v ochistnom zaboe sverkhkategornoy shakhty [Injury rate in the coal industry of Russia and prediction of methane explosion risk in the hazardous production facility - working face of the extreme explosion category mine]. Ugol' - Russian Coal Journal, 2017, No. 9, pp. 32-35. Available at: http://www. ugolinfo.ru/Free/092017.pdf (accessed 15.02.2018).

6. Safety rules in coal mines (PB 05-618-03). Series 05, Issue 11. Moscow, Federal state unitary enterprise "Scientific-technical center on safety in industry" Publ., 2005, 296 p.

\section{Группа СУЭК получила предэкспортный синдицированный кредит В размере 1,055 млрд долларов США на 5 лет}

12 марта 2018 г. Группа СУЭК подписала кредитное соглашение на сумму 1,055 млрд дол. США. Кредит со сроком погашения пять лет обеспечен за счет экспортных доходов Группы. Средства будут использованы для рефинансирования существующих кредитов СУЭК, а также для общих корпоративных целей. В синдикате приняли участие 18 финансовых институтов.

Главный финансовый директор СУЭК Николай Пилипенко отметил: «Мы довольны результатами этого синдиката и благодарны банкам-кредиторам за поддержку. Мы продолжим реализацию стратегии компании для до-

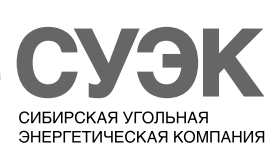

стижения наших финансовых, операционных целей и челей в области устойчивого развития».

\section{Наша справка.}

АО «СУЭК» - одна из ведущих угледобывающих компаний мира, крупнейший в России производитель угля, крупнейший поставщик на внутренний рынок и на экспорт. Добывающие, перерабатывающие, транспортные и сервисные предприятия СУЭК расположены в восьми регионах России. На предприятиях СУЭК работают более 33500 человек. Основной акционер - Андрей Мельниченко. 


\section{IMRC}

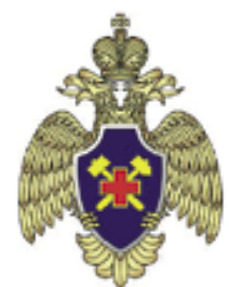

РосСия 2018
XI Международные

горноспасательные соревнования

\section{IMRC-2018}

Россия, г. Екатеринбург, 22-29 сентября 2018 г.
С 22 по 29 сентября 2018 г. в г. Екатеринбурге пройдуm XI Международные горноспасательные соревнования IMRC-2018. История проведения соревнований насчитывает почти 20 лет.

- Соревнования IMRC-2018 проводит Министерство Российской Федерации по делам гражданской обороны, чрезвычайным ситуациям и ликвидации последствий стихийных бедствий (МЧС России) под эгидой Международной горноспасательной организации (IMRB) при поддержке Правительства Свердловской области и муниципальных образований, лидирующих горнодобывающих предприятий, производителей горной и горноспасательной техники, ведущих российских горных университетов.

- Целью соревнований IMRC-2018 является не только выявление лучших горноспасателей мира, но и обмен опытом, оценка методов ведения горноспасательных работ для дальнейшего внедрения лучших практик в профессиональную деятельность.

- Ожидается, что в соревнованиях IMRC-2018 примут участие порядка 30 команд горноспасателей, а также более 100 ведущих экспертов в об-
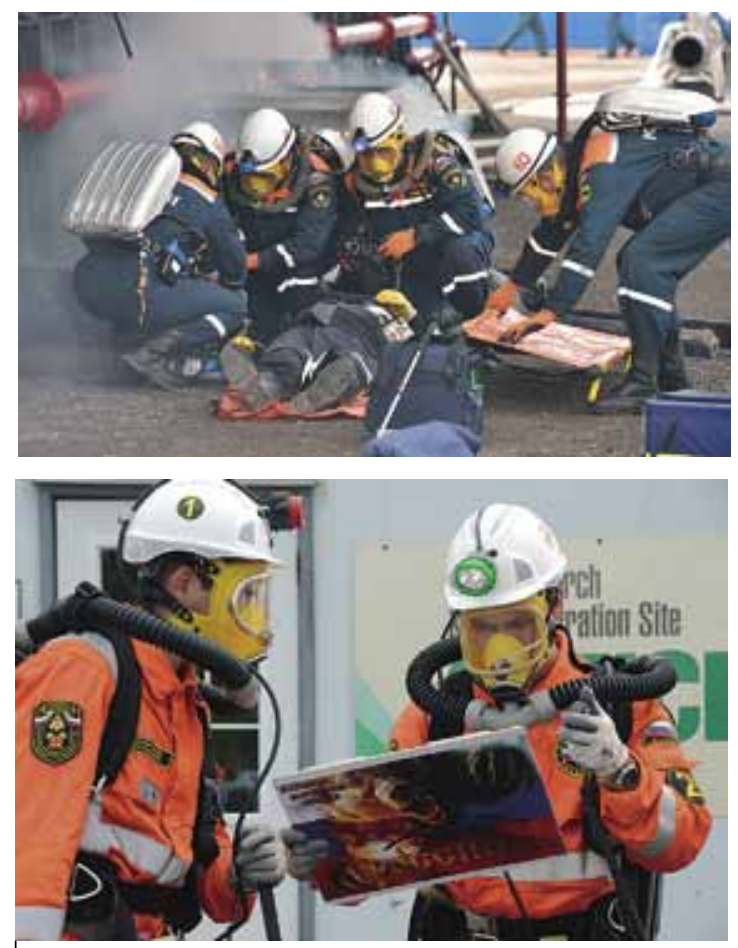

ласти обеспечения безопасности и противоаварийной защиты шахт и рудников из 20 стран мира с наиболее высоким уровнем развития горнодобывающей промышленности. В условиях реальных горнодобывающих предприятий Урала - Березовского рудника и карьера Урочище - горноспасатели продемонстрируют лучшие практики ведения горноспасательных работ, тушения подземных пожаров и оказания первой помощи пострадавшим. На базе Уральского государственного горного университета горноспасателям предстоит сдать теоретический экзамен, обнаружить и устранить неисправности основной горноспасательной техники, а также получить оценку действиям команды в условиях виртуальной шахты.

- Программой соревнований IMRC-2018 предусмотрено проведение семи этапов: «Горноспасательные работы», «Пожаротушение», «Оказание первой помощи», «Теоретический экзамен», «Соревнования техников», «Виртуальная реальность», а также «Горноспасательная эстафета» - наиболее зрелищный эпизод соревнований.

В любых соревнованиях важно показать лучший результат и завоевать награды, но наиболее важным результатом IMRC-2018 является глобальный обмен опытом, создание среды, в которой каждая команда сможет получить объективную оценку своих навыков и умений. Соревнования IMRC-2018, безусловно, послужат весомым вкладом в становление высокой культуры безопасности на предприятиях горной промышленности, а также станут стимулом для профессионального развития тех, кто связал свою жизнь с горным и горноспасательным делом.
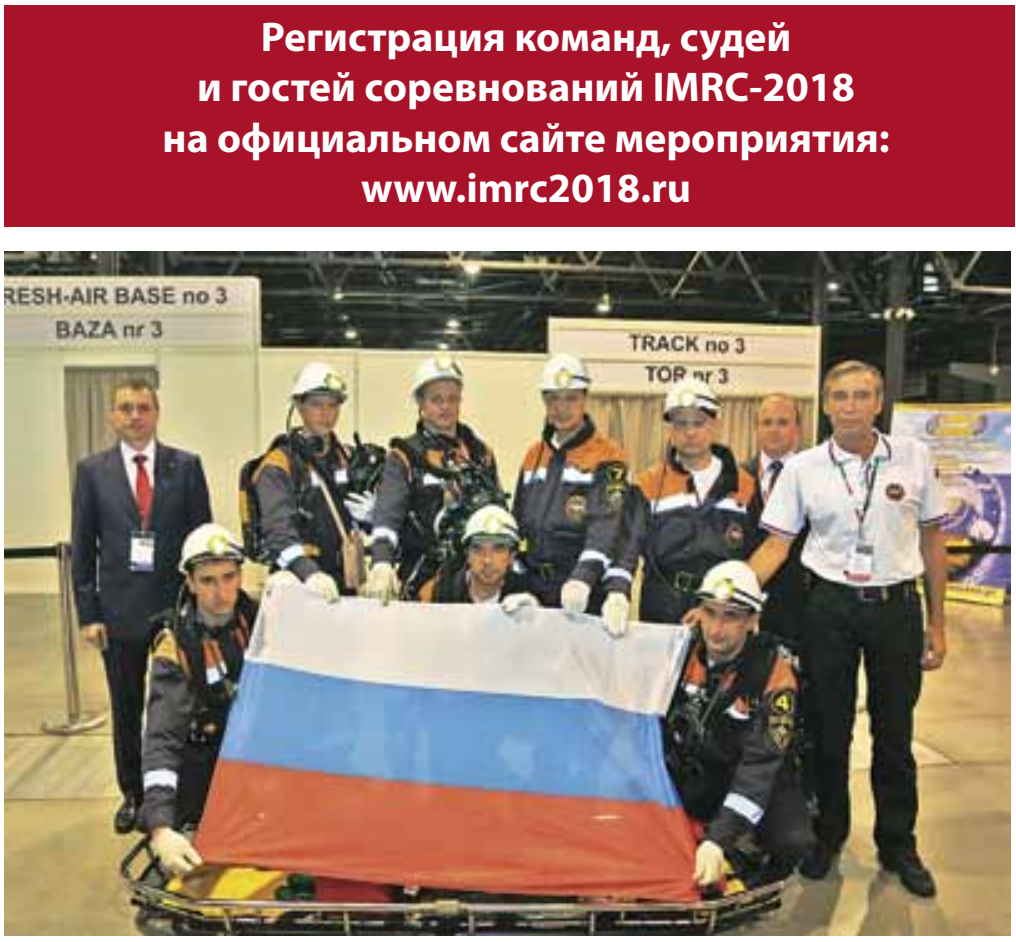


\section{Город Назарово стал обучающей площадкой для мастеров сервисных предприятий суЭК со всей России}

ООО «Назаровское горно-монтажное наладочное управление», сервисное предприятие Сибирской угольной энергетической компании в Красноярском крае, стало обучающей площадкой для ремонтного и наладочного персонала СУЭК со всей России.

На базе Назаровского ГМНУ проходит практический семинар по устройству и обслуживанию электроприводов экскаваторов. Участие в нем принимают электрослесари, мастера по наладке и электромеханики из городов Бородино, Назарово и Шарыпово Красноярского края, республик Бурятия и Хакасия, а также студенты Назаровского энергостроительного техникума, обучающиеся по специальности «Горный электромеханик».

Основная задача таких обучающих мероприятий - повышение компетенций сотрудников сервисных подразделений СУЭК. Как подчеркнул заместитель главного инженера ООО «Назаровское ГМНУ» по внедрению новой техники и технологий Владимир Васин, выступающий на семинаре в роли лектора, горное оборудование постоянно модернизируется, совершенствуется, и тем, кто работает с горнодобывающей техникой или занимается ее мон- тажом и ремонтом, просто необходимо быть в курсе всех новшеств и изменений. «Для насэто первый подобныйопыт наставничества, - добавил Владимир Васин. - Тем не менее коллектив Назаровского ГМНУ накопил достаточный опыт, он не стоит на месте, совершенствует свою деятельность, освачвает новые виды продукции и услуг. Думаю, что этот семинар принесет практическую пользу не только каждому из участников, но и предприятиям, где они работают, в челом».

Обучающий семинар рассчитан на три недели. Завершатся теоретический курс и практические занятия в цехах ГМНУ контрольным тестированием.

Назаровское ГМНУ сегодня является одним из ведущих сервисных предприятий в структуре СУЭК. На счету коллектива ГМНУ - участие в таких стратегических для компании проектах, как запуск американских экскаваторов BUCYRUS в Бурятии, электромонтажные работы на обогатительной фабрике в Хабаровском крае, модернизация экскаваторов на угольных разрезах страны. Успешно сотрудничают назаровцы и с предприятиями Мордовии, Монголии и другими.

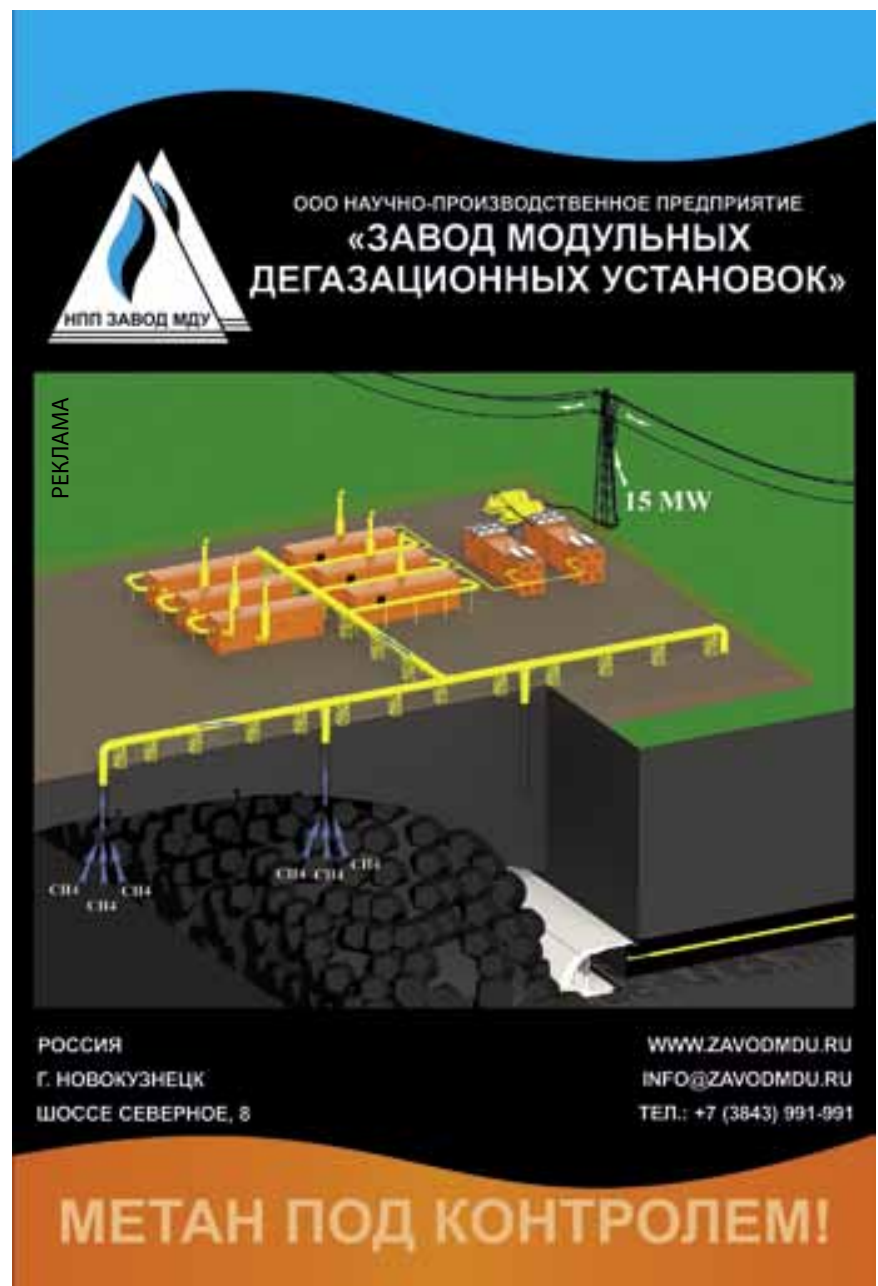

На шахте «Усковская» Распадской угольной компании ЕВРАЗа введена в работу новая лава 50-06. Ее запасы составляют 1,7 млн т коксующегося угля марки ГЖ.

Лава 50-06 оснащена высокопроизводительным добычным оборудованием, обеспечивающим эффективнуюугледобычу. Комбайн и другие элементы механизированного комплекса доставлены в забой с помощью современного дизелевозного транспорта, применяемого на шахте.

Большое внимание уделено безопасности шахтерского труда. Дегазационные работы проведены перед запуском лавы в эксплуатацию. Во время добычи угля применяются все виды дегазации, как подземным способом, так и с поверхности через скважины, пробуренные в выработанное пространство. Лава оборудована цифровыми датчиками контроля метана, кислорода и оксида углерода.

Уголь из лавы 50-06 добывает бригада Олега Москаленко участка по добыче угля № 5 (начальник участка Ярослав Ерченко). Ежегодно этот коллектив добивается высоких показателей по производительности труда в Распадской угольной компании. По итогам февраля 2018 г. горняки добыли из новой лавы 230 тыс. тугля. В дальнейшем планируют увеличить ежемесячную нагрузку на забой до 250-270 тыс. т.

Шахта «Усковская» добывает коксующийся уголь марки ГЖ, который после обогащения на ЦОФ «Кузнецкая» и «Абашевская» отгружается на металлургические предприятия ЕВРАЗа. Также он пользуется спросом у сторонних потребителей в Польше, Словакии, Венгрии и на Украине. 


\section{Совершенствование методологии повышения квалификации руководителей и специалистов особо опасных производств ТЭКа как способ решения проблем безопасности}

DOI: http://dx.doi.org/10.18796/0041-5790-2018-4-38-41

\author{
ХолодОв Павел Павлович \\ Канд. экон. наук, дочент, \\ дочент кафедры «Менеджмент» ФГАОУ ДПО \\ «КемРИПК», \\ 650002, г. Кемерово, Россия, \\ тел.: + 7 (3842) 64-34-18, e-mail: hpp@yandex.ru
}

\author{
ЮНГБЛЮДТ Сергей Викторович \\ Канд. экон. наук, дочент, \\ ректор ФГАОУ ДПО «КемРИПК», \\ 650002, г. Кемерово, Россия, \\ тел.: + 7 (3842) 64-14-20, e-mail: kemripk@mail.ru
}

\section{БОТВЕНКО Людмила Авельевна}

Канд. техн. наук, дочент,

заведующая кафедрой

«Менеджмент» ФГАОУ ДПО «КемРИПК»,

650002 , г. Кемерово, Россия,

тел.: + 7 (3842) 64-36-28, e-mail: kemripk@mail.ru

В статье изложены основные направления совершенствования методологии повышения квалификации специалистов особо опасных производств, предложена система повышения квалификации какмногоуровневое обучение специалистов опасных производств.

Ключевые слова: повышение квалификации, методы обучения, опасные производства, безопасность.

\section{ВВЕДЕНИЕ}

Одним из первостепенных факторов обеспечения надежного и безаварийного функционирования особо опасных производственных объектов становится сегодня уровень профессиональной компетенции эксплуатирующего их персонала. В свою очередь данный момент напрямую связан с постоянным и планомерным повышением квалификации данных работников, их непрерывным обучением и развитием. Уже ни для кого не секрет, что именно в уровне оптимального обеспечения предприятия компетентными и подготовленными кадрами кроется основной ключ не только к развитию любого производства, но и к простому вопросу его выживания в острой конкурентной среде.

Именно низкий уровень подготовки имеющегося персонала либо фактическое отсутствие должным образом подготовленных квалифицированных кадров, способных осуществить не только технологическую модернизацию средств производства, но и просто грамотно эксплуатировать имеющееся оборудование, являются сегодня одной из фундаментальных проблем и вызовов, с которыми сталкиваются российские бизнес-структуры.

Решение данной проблемы маловероятно без переосмысления места и роли системы дополнительного профессионального образования (ДПО) и повышения квалификации персонала в общей структуре управления кадровым потенциалом каждого конкретного предприятия.

\section{МЕСТО И РОЛЬ СИСТЕМЫ ДПО В ДЕЛЕ ПРИОБРЕТЕНИЯ ПРОФЕССИОНАЛЬНЫХ КОМПЕТЕНЦИЙ, ДОСТАТОЧНЫХ \\ ДЛЯ ЭКСПЛУАТАЦИИ ОПАСНЫХ ПРОИЗВОДСТВ}

Следует отметить, что современное как высшее, так и дополнительное профессиональное образование перешло на новую парадигму, в основу которой положен принцип формирования «человека мыслящего», способного к творчеству, самосовершенствованию, поэтому в системе повышения квалификации постепенно происходят соответствующие изменения, и мы должны менять как методы, так и способы обучения, то есть все составляющие данной системы требуют постоянного совершенствования. Также изменяется и методическая модель учебного процесса.

Методические схемы обучения выбираются в зависимости от конкретных условий организации учебного процесса и потребностей региона и осуществляются по наиболее важным характеристикам учебного процесса. Это дифференциация слушателей по интересам и уровню начальной подготовки; разнообразие форм и структуры; преобладание практических занятий и широкое использование интерактивных методов, обеспечивающих приобретение слушателями необходимых практических навыков; большой удельный вес самостоятельной работы; учет специфики практической деятельности слушателей; использование знаний и практического опыта слушателей. А характеристики учебного процесса зависят от интересов и возможностей слушателей в освоении образовательной программой (определяются по результатам входного тестирования); продолжительности обучения; вида и уровня базового образования слушателей; области практической деятельности слушателя и его намерений сохранить ее в будущем; обеспеченности методическими материалами; квалификации преподавателей. 


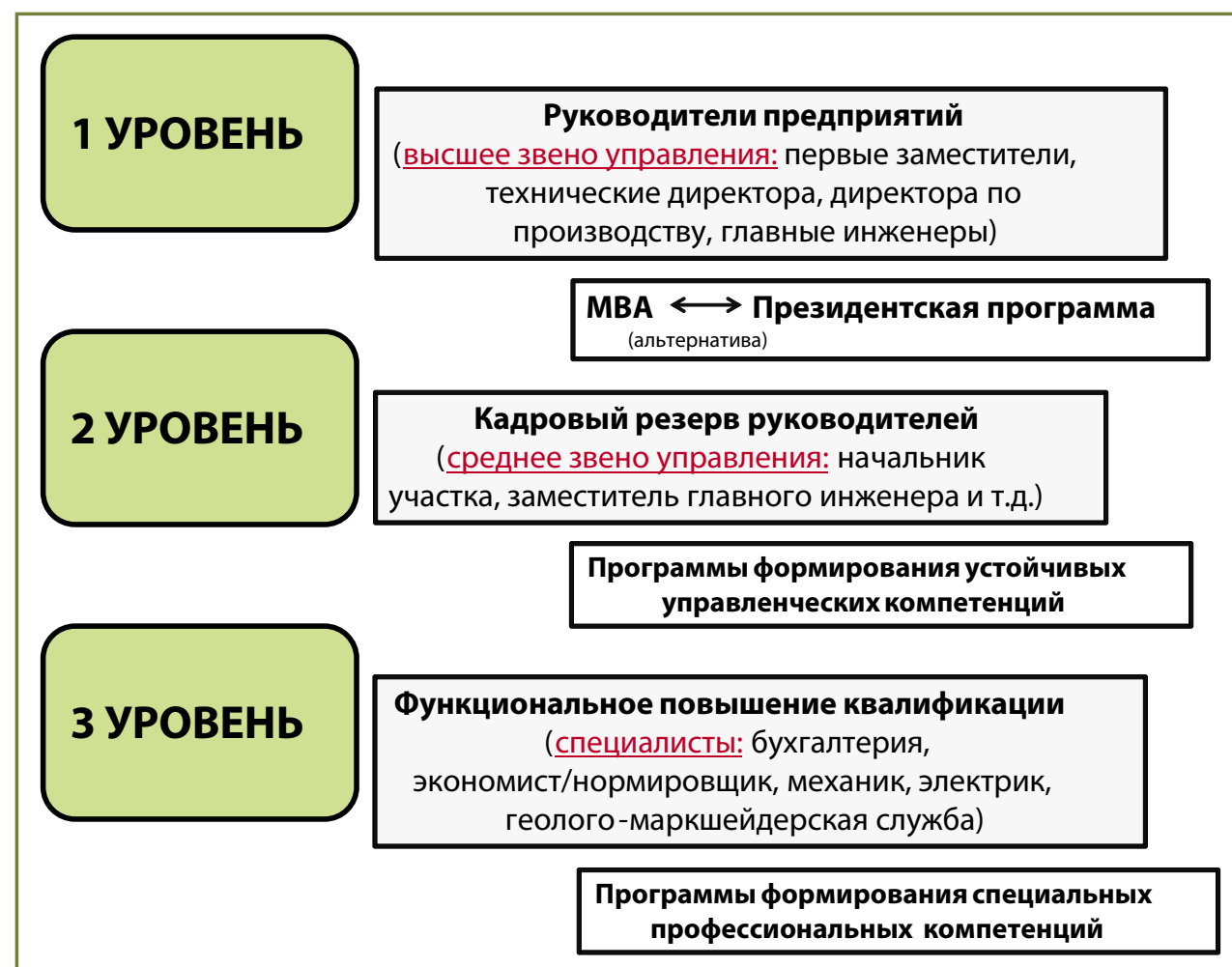

Pис. 1. Система многоуровневого обучения руководителей и специалистов

Fig. 1. Multi-level leadership and specialists training system

В настоящее время возникают новые требования общества к уровню образования, к профессиональной компетенции руководителей и специалистов особо опасных производств, а также к их личностным качествам, способности действовать в нестандартных ситуациях и быстро принимать правильные решения в аварийных ситуаци-

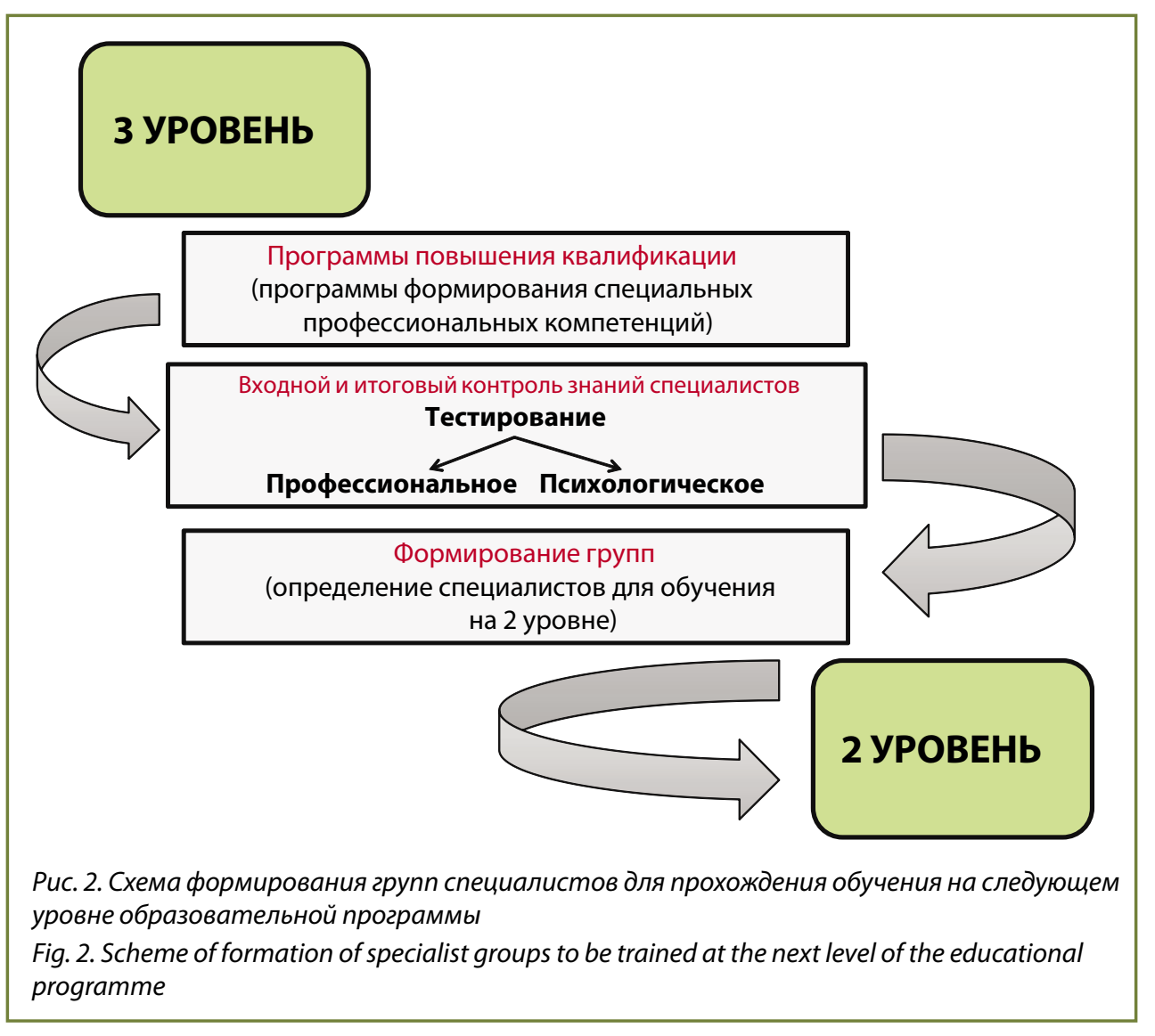

ях. Анализируя аварии и инциденты, видим, что причиной их часто является недостаточная профессиональная компетентность людей, которые входят в структуру управления компаний, поскольку во главу угла ставится не человек и его безопасность, а объем добычи, финансовые результаты. Конечно, в последние годы безопасности уделяется большое внимание. Но чаще при решении технических проблем обеспечения безопасности, к сожалению, уделяется мало внимания человеку, его профессиональной подготовке в сфере безопасности.

Однако данная проблема успешно решается при достаточно четком взаимодействии структур предприятий, ответственных за управление кадровым потенциалом, с организациями, занимающимися дополнительным профессиональным образованием и/или повышением квалификации сотрудников. К примеру, разработанная нашим институтом система подготовки - повышения квалификации ориентирована на приобретение профессиональных компетенций, необходимых для безопасного ведения работ на опасных производствах, так называемое опережающее, многоуровневое обучение руководителей и специалистов (рис.1).

Самый начальный уровень это третий. Это повышение квалификации руководителей и специалистов, то есть на данном этапе формируются специальные профессиональные компетенции. Улучшение качества обучения по программам повышения квалификации - это практикоориентированный подход к обучению. Одним из приоритетных направлений этого обучения является информатизация образования - электронное, дистанционное обучение.

На сегодняшний день проблема создания электронных изданий и ресурсов актуальна, мы предлагаем один из путей ее решения - создание электронных образовательных ресурсов для самостоятельной работы слушателей, создание электронного обучаю- 
щего мультимедийного ресурса, значительно индивидуализирующего учебный процесс, увеличивающего скорость и качество усвоения учебного материала, существенно усиливающего практическую направленность, в целом - повышающего качество образования. После повышения квалификации и при прохождении тестирования (профессионального и психологического) происходит формирование групп специалистов для прохождения обучения на втором уровне (рис. 2).

На втором уровне программы повышения квалификации направлены на формирование устойчивых управленческих компетенций (знаний, умений, навыков). В данные программы включены вопро-

сы менеджмента, экономики, психологии, и формируются они с учетом требований заказчика и специфики особо опасного производства.

После прохождения обучения на втором уровне возможно уже после определенного тестирования отбирать специалистов для назначения их на вышестоящие должности, то есть это позволяет формировать кадровый резерв для особо опасных производств, что в определенных условиях является очень сложной задачей (рис. 3).

Следует отметить, что основная цель деятельности любой из составляющих системы ДПО состоит в повышении уровня профессиональной компетентности руководителей и специалистов при решении различных производственных организационных и технических задач, в том числе и в чрезвычайных ситуациях. А в качестве одной из основополагающих задач данной системы подготовки следует выделить приобретение умений быстро, четко и с минимальными рисками действовать в стандартных и нестандартных ситуациях.

\section{ЗАКЛЮЧЕНИЕ}

В целом необходимо отметить, что функционирующая на должном уровне система повышения квалификации должна позволить не только повысить качество профессиональной подготовки кадров, но и более успешно решать проблемы безопасности производства и формирования кадрового резерва компании и в целом оказывать определенное стабилизирующее воздействие на функционирование как отдельных опасных производственных объектов, так и всей угольной отрасли в целом.

\section{Список литературы}

1. Алавердов А.Р. Управление человеческими ресурсами организации. М.: Московский финансово-промышленный университет «Синергия», 2012.656 с.

2. Друкер П. Менеджмент. Вызовы XXI века. М.: Манн, Иванов и Фарбер, 2012. 256 с.
3. Каганов В.Ш. Корпоративное обучение как фактор обеспечения конкурентоспособности предпринимательских структур. М.: МГОФ «Знание», 2012. 344 с.

4. Русак О.Н. Управление безопасностью труда: Монография. СПб.: Стратегия будущего, 2011. 180 с.

5. Методы эффективного обучения взрослых: учебнометодическое пособие. Институт повышения квалификации государственных служащих Российской академии государственной службы при Президенте Российской Федерации. М., 1999. 154 с.

6. Менеджмент в сфере охраны труда, промышленной, экологической безопасности на особо опасных производствах: учебно-методическое пособие / Л.А. Ботвенко, Е.В. Лякин, П.П. Холодов, Н.Л. Чурина. Кемерово: АИ «Кузбассвузиздат», 2017. 168 с.

7. Федченко Ю.А., Лякин Е.В., Ботвенко Л.А. Охрана труда: учебное пособие. Кемерово: ФГАОУ ДПО «КемРИПК», 2014. 368 с.

8. Федченко Ю.А. Учитесь у тех, кто ценит качество // Аккредитация в образовании. 2010. № 2.

9. Федченко Ю.А. Ключ к безопасности труда // Уголь Кузбасса. 2010. № 5.

10. Федченко Ю.А. Программно-целевой подход к обучению отдельных категорий застрахованных / ФГУ ВЦОТ Россздрава. Сборник трудов. М., 2007.

11. PwC Saratoga 2012: Results of the study of the effectiveness of the personnel management system. PwC, 2012.

12. Bellè N. Performance-related pay and the crowdingout of motivation in the public sector: A randomized field experiment // Public Administration Review. 2015. N 75,

13. Heslin P.A., Vande Walle D. Performance appraisal procedural justice: The role of a manager's implicit person theory // Journal of Management. 2011. N 37.

14. Meng F., Wu J. Merit pay fairness, leader-member exchange, and job engagement: Evidence from mainland China // Review of Public Personnel Administration. 2015. N 35 . 
UDC 658.386.37:622.8 @ P.P. Kholodov, S.V. Jungbludt, L.A. Butvenko, 2018

ISSN 0041-5790 (Print) • ISSN 2412-8333 (Online) • Ugol' - Russian Coal Journal, 2018, № 4, pp. 38-41

Title

IMPROVING THE METHODOLOGY OF TRAINING OF MANAGERS AND SPECIALISTS PARTICULARLY HAZARDOUS INDUSTRIES, ENTERPRISES OF FUEL AND ENERGY COMPLEX AS A WAY OF SOLVING SECURITY PROBLEMS

DOI: http://dx.doi.org/10.18796/0041-5790-2018-4-38-41

\section{Authors}

Kholodov P.P. ${ }^{1}$, Jungbludt S.V. ${ }^{1}$, Butvenko L.A. ${ }^{1}$

${ }^{1}$ Regional institute of professional development, Kemerovo, 650002, Russian Federation

\section{Authors' Information}

Kholodov P.P., PhD (Economic), Associate Professor, Associate Professor of the Department of Management, tel.: 7 (3842) 64-34-18, e-mail: hpp@yandex.ru Jungbludt S.V., PhD (Economic), Associate Professor, Rector,

tel.: + 7 (3842) 64-14-20, e-mail: kemripk@mail.ru

Butvenko L.A., PhD (Engineering), Associate Professor, Head of the Department of Management, tel.: +7 (3842) 64-36-28, e-mail: kemripk@mail.ru

\section{Abstract}

In the paper the basic directions of perfection of methodology of training specialists of especially hazardous production of production, the proposed system of qualification as a multi-level training of specialists of hazardous production facilities.

Figures:

Fig. 1. Multi-level leadership and specialists training system

Fig. 2. Scheme of formation of specialist groups to be trained at the next level of the educational programme

Fig. 3. Algorithm for formation of high-potential employees to be appointed to higher positions

\section{Keywords}

Training, Methods of training, Hazardous production, Safety.

\section{References}

1. Alaverdov A.P. Upravlenie chelovecheskimi resursami organizatsii [Company human resource management]. Moscow, Moscow Financial and Industrial University "Synergy" Publ., 2012, 656 p.

2. Druker P. Menedzhment. Vyzovy XXI veka [Management. Challenges of the 21 th century]. Moscow, Mann, Ivanov and Farber Publ., 2012, 256 p.

3. Kaganov V.Sh. Korporativnoe obuchenie kak faktor obespecheniya konkurentosposobnosti predprinimatel'skikh struktur [Corporate training as a factor of ensuring business structure competitiveness]. Moscow, MGOF "Znanie" Publ., 2012, 344 p.

4. Rusak O.N. Upravlenie bezopasnost'yu truda: Monografiya [Labour safety management: Monograph]. Saint-Petersburg, Strategy of future Publ., 2011, 180 p.
5. Metody effektivnogo obucheniya vzroslykh [Methods of efficient adult learning]. Uchebno-metodicheskoe posobie Institut povysheniya kvalifikatsii gosudarstvennykh sluzhashchikh Rossiyskoy akademii gosudarstvennoy sluzhby pri Prezidente Rossiyskoy Federatsii [Guidance manual Institute for Advanced Training of Public Officials of the Russian Academy of Public Service under the President of the Russian Federation], Moscow, 1999, 154 p. 6. Botvenko L.A., Lyakin E.V., Kholodov P.P. \& Churina N.P. Menedzhment v sfere okhrany truda, promyshlennoy, ekologicheskoy bezopasnostina osobo opasnykh proizvodstvakh: Uchebno-metodicheskoe posobie [Management in the field of labour protection, industrial, environmental safety in specially hazardous production facilities: Guidance manual]. Kemerovo, Al "Kuzbassvuzizdat" Publ., 2017, 168 p.

7. Fedchenko Yu.A., Lyakin E.V. \& Botvenko L.A. Okhrana truda: Uchebnoe posobie [Labour Protection: Educational aid]. Kemerovo, FGAOU DPO (Federal state autonomous educational institution of supplementary vocational education) «KemRIPK» Publ., 2014. 368 p.

8. Fedchenko Yu.A. Uchites' u tekh, kto tsenit kachestvo [Learn from those who appreciate the quality]. Akkreditatsiya $v$ obrazovanii - Accreditation in education, 2010, No. 2.

9. Fedchenko Yu.A. Klyuch k bezopasnosti truda [Key to labour safety]. Ugol' Kuzbassa - Kuzbass Coal, 2010, No. 5

10. Fedchenko Yu.A. Programmno-tselevoy podkhod k obucheniyu otdel'nykh kategoriyzastrakhovannykh [Programme-target approach to training of some categories of insured]. Collection papers. Moscow, FGUVCOT Rosszdrav Publ., 2007. 11. PwC Saratoga 2012: Results of the study of the effectiveness of the personnel management system. PwC, 2012.

12. Belle N. Performance-related pay and the crowding-out of motivation in the public sector: A randomized field experiment. Public Administration Review, 2015, No. 75.

13. Heslin P.A. \& Vande Walle D. Performance appraisal procedural justice: The role of a manager's implicit person theory. Journal of Management, 2011, No. 37. 14. Meng F. \& Wu J. Merit pay fairness, leader-member exchange, and job engagement: Evidence from mainland China. Review of Public Personnel Administration, 2015, No. 35.

\section{Минприроды России наградило руководство СУЭК}

\section{за вклад в охрану природы}

30 марта 2018 г. прошло заседании Коллегии Министерства природных ресурсов и экологии Российской Федерации, на котором, в частности, был отмечен вклад руководителей крупнейших российских промышленных компаний в охрану природы. Так, генеральный директор АО «СУЭК» Владимир Рашевский награжден знаком «Почетный работник охраны природы». Заместитель генерального директора АО «СУЭК», президент Фонда «СУЭК - РЕГИОНАМ», заместитель председателя Общественного совета при Минприроды РФ Сергей Григорьев был награжден знаком «Отличник охраны природы».

«Почетный работник охраны природы» и «Отличник охраны природы» - это ведомственные знаки отличия Минприроды России, которые вручаются за большой вклад в дело сохранения природы, биологического разнообразия, экологической безопасности, просвещения и пропаганды экологических знаний.

Обеспечение экологической безопасности, минимизация экологических рисков производства и охрана природы являются неотъемлемой частью стратегии устойчивого развития
СУЭК. Компания реализует комплекс мероприятий по охране воздушных ресурсов (дегазация шахт и утилизация метана), охране водных ресурсов (очистка сточных вод), энергоэффективности, рекультивации земель и сохранению биоразнообразия. Деятельность СУЭК в сфере экологии неоднократно отмечена профессиональным сообществом - компания является, в частности, победителем премий EraEco (при поддержке UNIDO и Минприроды России), Evolution Awards, Eco Best Award, является лидером рейтинга экологической ответственности горнодобывающих компаний WWF. В 2017-2018 гг. СУЭК направляет около 3,5 млрд руб. на реализацию экологических мероприятий. В 2017 г. СУЭК подписала с Минприроды России, Росприроднадзором и администрациями регионов, в которых работают предприятия компании, 10 соглашений о взаимодействии в области реализации природоохранных мероприятий на сумму более 6 млрд руб. По итогам 2017 года СУЭК вошла в число компаний, показавших наилучшие результаты по реализации совместных мероприятий с Минприроды России в Год экологии. 


\section{СУЭК дала официальный старт Году добровольца (волонтера) в шахтерских городах края}

В шахтерских городах Красноярского края дали торжественный старт Году добровольча (волонтера). Идея собрать вместе активистов различных волонтерских движений - $а$ их на каждой из территорий действует более десяти - принадлежит Сибирской угольной энергетической компании.

«Волонтерство в нашей стране стремительно набирает обороты: тех, кого чужая нужда не оставляет равнодушными, кто всегда готов прийти на помощь, среди нас становится все больше. Иполныезалы добрых, отзывчивых, с открытым сердием людей самых разных возрастов - очередное тому подтверждение», - отмечает заместитель генерального директора АО «СУЭК-Красноярск» по связям и коммуникациям Марина Смирнова.

Волонтерские форумы в Бородино, Назарово и Шарыпово объединили около тысячи человек. Среди них - школьники, учителя, врачи, деятели культуры, спорта, социальные работники, даже пенсионеры - во всех городах они работают под эгидой движения «Серебряное волонтерство». В Бородино, например, инициативные пенсионеры совместно с муниципальным молодежным центром организовали клуб «В гостях у бабушки», где обучают ребят кулинарии.

Свои волонтерские инициативы в рамках форумов представили и сами угольщики. Совет молодежи Назаровского разреза, например, реализует проект «Час заботы»- вме-

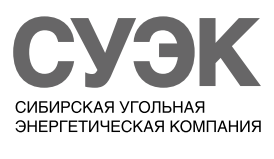

сте с артистами ГДК и трудовыми отрядами СУЭК горняки организуют досуг пожилых людей, проживающих в районном Доме ветеранов: проводят праздники, мастер-классы, дарят подарки. Подарки детям из малообеспеченных семей регулярно собирают молодые специалисты бородинских предприятий СУЭК, они активные участники городских акций «Подари ребенку Рождество» и «Помоги пойти учиться». В Шарыпово молодежный совет взял шефство над ребятами из Центра социальной помощи семье и детям «Шарыповский».

После мероприятий все желающие смогли получить «Книжки волонтера» - своего рода «зачетки», где оценкой их бескорыстного труда станут слова благодарности тех, кому они оказали поддержку.

Главы шахтерских территорий поблагодарили СУЭК за то, что компания дает дополнительный стимул для развития волонтерства в городах, выразив надежду, что ее примеру последуют другие крупные организации и предприятия.

Добавим, СУЭК Андрея Мельниченко на протяжении всей своей истории проводит на территориях присутствия максимально масштабную социальную и благотворительную политику. За прошедшие годы только в Красноярском крае на поддержку молодежных инициатив, в том числе связанных с волонтерской деятельностью, развитие здравоохранения, образования, культуры и спорта компания выделила свыше миллиарда рублей.
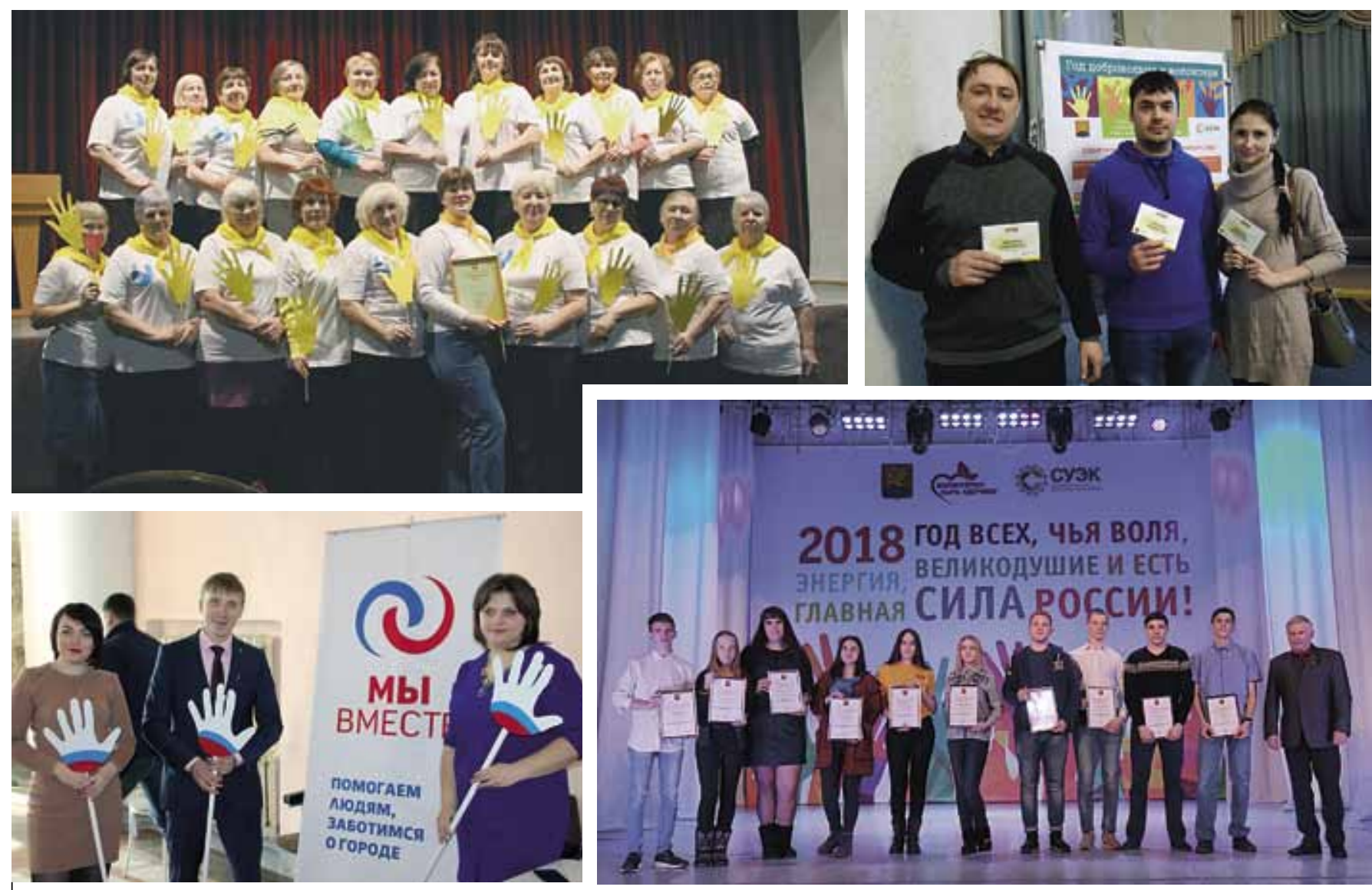


\section{Смерзание и пыление угля: проблемы и решения}

Процессы добычи и транспортировки угля как сыпучего груза сопровождаются двумя основными проблемами по частоте упоминания в СМИ и самими угольщиками: смерзание и пыление.

«Правилами перевозок смерзающихся грузов на железнодорожном транспорте», утвержденными Приказом Министерства путей сообщения РФ от 05.04.1999 № 20Ц, предусматривается, что до предъявления к перевозке грузов, подверженных смерзанию, грузоотправитель должен принять меры к уменьшению их влажности до безопасных в отношении смерзания пределов, установленных ГОСТами, техническими условиями на продукцию.

При отсутствии возможности, а, как правило, такая подготовка груза либо невозможна технически, либо экономически неоправданна, грузоотправитель обязан принять дополнительные меры к предотвращению смерзания груза и его примерзания к стенкам полувагона в процессе его транспортировки.

Правилами предусматриваются несколько способов подготовки смерзающихся грузов к отправке, которые можно разделить на следующие группы:

- предварительная сушка насыпных грузов до безопасной влажности;

- предварительное промораживание увлажненных грузов до их погрузки;

- равномерная обработка груза в массе, а также пола и стенок полувагонов и платформ профилактическими средствами различной природы;

- пересыпка груза разнообразными инертными материалами, например древесными опилками.

Каждый из вышеописанных способов имеет свои достоинства и недостатки, однако с экономической точки зрения, наиболее эффективным способом является использование специальных реагентов с последующим нанесением на внутреннюю поверхность вагонов, а также послойная или в массе обработка самого груза различными составами против смерзания.

Несоблюдение мер по предотвращению смерзания грузов приводит к резкому росту издержек у грузополучателей, обусловленных необходимостью проведения дополнительных операций по обеспечению возможности выгрузки смерзшегося груза и их последствиями. Это и использование так называемых тепляков, и затратная механическая выгрузка с очисткой внутренней поверхности полувагона, и затраты, связанные с вынужденным простоем подвижного состава.

Хлористый магний зарекомендовал себя как эффективный реагент, препятствующий смерзанию сыпучих грузов, что подтверждено его внедрением в технологический цикл транспортировки на таких предприятиях, как АО ХК «Якутуголь», АО «Сибирский Антрацит», $А О$ «Ванинский морской порт», ГК «ПетропавловскЧерная металлургия» и $\partial p$.
Вышеуказанными потребителями подтверждается, что выгодно обрабатывать уголь хлористым магнием против смерзания уже после первых суток простоя (за счет соотношения: цена реагента / цена простоя подвижного состава), кроме этого, за счет обработки хлористым магнием снижается количество простаивающих полувагонов.

\section{Экономика использования хлористого магния}

\section{против смерзания:}

- расход реагента - 3-4 тыс. руб./полувагон с НДС (с доставкой в Кемерово/Красноярск/Новосибирск);

- штраф за простой полувагона - 2124 руб./сут. с НДС.

Составы против смерзания на основе хлористого магния выгодно отличаются от другиханалогичных средств в том числе от реагентов нефтяного происхождения, которые имеют более высокую цену и резкий запах. Горючесть таких реагентов обусловливает более высокие затраты на монтаж и эксплуатацию установок для обработки грузов, а наличие серы в составе ведет к увеличению серности угля.

Хлористый магний имеет низкую точку кристаллизации. Наибольшей эффективностью для обработки против смерзания обладает хлористый магний с массовой концентрацией 20-21\% и плотностью 1,18-1,19 г/см³. При этой концентрации реагент обладает наиболее низкой температурой кристаллизации - минус $33,5^{\circ} \mathrm{C}$.

Составы на основе хлористого магния характеризуются существенно более низкой коррозионной активностью в сравнении с хлоридами натрия. При концентрации хлористого магния на уровне 15\% и выше его коррозионная активность, согласно проведенным исследованиям, не превышает уровень активности водопроводной воды.

Составы против смерзания на основе хлористого магния выпускаются в твердой форме, что, во-первых, существенно снижает затраты на транспортировку к месту использования и, во-вторых, дает возможность применения как в твердом, так и в жидком виде в зависимости от наличия того или иного оборудования, температурных условий и прочих факторов.

Рекомендуемый расход реагента - около 3-5 кг на 1 т смерзающегося груза. При обработке груза у грузоотправителя на конвейерной ленте монтируется растариватель биг-бегов с шнековой подачей реагента на ленту. В случае обработки смерзающегося груза в штабеле хлористый магний может перемешиваться непосредственно с массой груза. Простота и доступность этих решений гарантируют качественный и малозатратный результат.

Хлористый магний, обладая высокой гигроскопичностью, активно абсорбирует влагу, находящуюся на поверхности груза и препятствует его смерзанию. Благодаря твердой форме выпуска, появляется возможность комбинированного использования состава на основе хлористого магния - обработка поверхности вагона и послойная пересыпка груза твердой формой, что гарантированно исключит сложности при его последующей разгрузке у грузополучателя. 
Кроме проблемы смерзания угля, в свете последних тенденций в сфере природоохранных инициатив Президента и Правительства Российской Федерации, становится все более актуальной решение проблемы пыления угля. Причем речь идет не только об экологических аспектах функционирования соответствующих промышленных предприятий, а в большей степени о безопасности населения, проживающего в непосредственной близости от мест хранения и перевалки угля.

Наиболее интенсивным пылением сопровождается перевалка открытым способом с применением грейферной погрузки, прямой выгрузки из вагонов в трюм судна, движения транспортной техники по технологическим дорогам в местах добычи угля, в местах выгрузки и хранения, на обогатительных фабриках. При этом пыление с мест хранения угля насыпью менее интенсивное, но в отличие от вышеперечисленных случаев - постоянное и, как следствие, не менее пагубное.

Технологические операции с сыпучими грузами без специальных мероприятий по снижению пыления, однозначно, приводят к тому, что вредные вещества оседают на прилегающей акватории и почве, что негативно сказывается на растительном и животном мире и создает угрозу здоровью людей, проживающих в населенных пунктах, расположенных в непосредственной вблизи от таких зон. Нарушение технологий, условий перевалки приводит к повышенному загрязнению атмосферного воздуха и нарушению экологических норм. Поэтому все организации, осуществляющие транспортировку, перевалку и хранение пылящих грузов, обязаны осуществлять мероприятия по снижению пыления и минимизации его воздействия на экологию и здоровье людей.

В настоящее время применяются несколько способов борьбы с пылением сыпучих грузов, которые условно можно разделить на несколько основных групп.

K nервой групnе можно отнести организационные мероприятия, направленные на оптимизацию погрузочноразгрузочных работ, - рациональное размещение оборудования и мест разгрузки-погрузки, оптимизация режимов работ и пр.

Ко второму способу относятся разнообразные способы укрытия мест интенсивного пыления - создание различных ограждений, размещение технологических узлов в крытых помещениях, организация ветрозащитных экранов и др.

Достаточно распространенным и, едва ли не самым популярным способом борьбы с пылью является увлажнение сыпучих материалов, в том числе и угля в процессе погрузки и во время его хранения. Оно может производиться путем орошения или создания завесы из водяного тумана. Технологически, системы орошения могут размещаться как на самом погрузочном оборудовании, например на портальных кранах, так и иметь мобильное исполнение - различные передвижные туманообразующие и аспирационные установки.
Также достаточно эффективным является способ закрепления пылящих поверхностей с помощью различных реагентов - места хранения грузов обрабатываются специальными составами, создающими устойчивую к ветру корку.

Последние два способа являются наиболее распространенными в мировой практике. Первые два из перечисленных способов достаточно капиталоемки и труднореализуемы на уже функционирующих объектах. К недостаткам способа увлажнения можно отнести невозможность его применения в зимний период, а в России около 70\% угольных терминалов работают в условиях длительного периода отрицательных температур.

Применение для целей снижения пыления специальных составов на основе природного минерала - хлористого магния, при необходимости дополняемых функциональными добавками, выгодно отличается от вышеперечисленных способов. Связывая мелкие частицы твердой фракции, такие составы создают на поверхности груза достаточно прочную ветроустойчивую корку, препятствующую дальнейшему пылению. Обладая повышенной гигроскопичностью, хлористый магний после обработки груза абсорбирует влагу даже из воздуха с пониженной влажностью, поддерживая обеспыливающий эффект от обработки в разы большее время по сравнению с аспирацией водой.

Технологически процесс использования составов на основе хлористого магния не отличается от применения обычного увлажнения пылящего груза. Для пылеподавления используется растворенный в воде хлористый магний с плотностью 1,2 г/см³. Время растворения твердого хлористого магния составляет от 3 до 5 мин. в зависимости от температуры воды. Приготовленное средство распыляется на обеспыливаемую поверхность с использованием доступного оборудования. Для обработки 1 кв. м обеспыливаемой поверхности требуется примерно 0,1 кг твердого хлорида магния.

В 2015-2018 гг. специалисты российских угольных компаний провели сравнительный анализ эффективности процесса обеспыливания водой и хлормагниевыми составами на поверхностях технологических дорог. Согласно полученным AO «Сибирский Антрацит» данным, применение составов на основе хлористого магния позволило снизить содержание взвешенных веществ в воздухе на 57-85\%. Технологические дороги обрабатывались в 3 раза реже, при этом использовалось меньшее количество машин - количество их рейсов сократилось на 264 раза в месяц. Общий расход воды за один рейс снизился на $25 \%$.
АО «КАУСТИК» (2. Волгоград) является крупнейшим российским производителем различных магнезиальных продуктов (хлорид магния, оксид магния, гидроксид магния), в том числе узкоспециализированных многокомпонентных средств для различных отраслей промышленности.

Специалисты предприятия могут оказать научную и техническую поддержку на стадии апробации использования составов на основе хлористого магния и в процессе их промышленного применения. АО «КАУСТИК» при необходимости готово предоставить образцы продукции для проведения лабораторных и практических испытаний. Дополнительную информацию можно всегда получить на сайте - www. austik.ru. 


\section{Назаровские предприятия СУЭК обновляют автопарк}

Назаровские предприятия Сибирской угольной энергетической компании обновляют парк автотехники. В рамках программы СУЭК по улучшению условий труда и быта сотрудников на Назаровский разрез поступили новые вахтовые автобусы «Урал NEXT». Машины отличаются повышенной проходимостью и предназначены для перевозки угольщиков по сложным производственным трассам: благодаря шестицилиндровому турбированномудвигателю и модернизированномушасси они без труда преодолевают распутицу, затяжные подъемы и спуски. При своих внушительных габаритах - длине 9 м и ширине почти 2,5 м - «Урал» способен развивать скорость до 85 км/ч. Также технические характеристики вездехода позволяют эксплуатировать его в непростых климатических условиях Сибири при температуре от -50 до $+40{ }^{\circ} \mathrm{C}$.

«В данной модели вахтового автобуса «Урал» созданы оптимальные условия для перевозки людей, - отмечает директор по производству АО «Разрез Назаровский» Александр Зиновьев. - В салоне, рассчитанном на перевозку 20 пассажиров, мягкие сиденья, обязательные ремни безопасности, более мощная система обогрева. В кабине водителя установлены бортовой компьютер и система круизконтроля. Техника хорошая, современная, думаю, наш коллектив оценит новинки».
Добавим, пока на Назаровский разрез прибыло два вездехода «Урал Next», в ближайшее время поступят еще три аналогичных вахтовых автобуса. С начала года это уже второе обновление автопарка предприятия, цель которого - повышение безопасности и качества перевозок. Месяцем ранее разрез и Назаровское горно-монтажное наладочное управление, сервисное подразделение СУЭК, получили шесть новых пассажирских автобусов повышенной вместимости и комфортности для городских поездок и передвижения по карьерным дорогам.

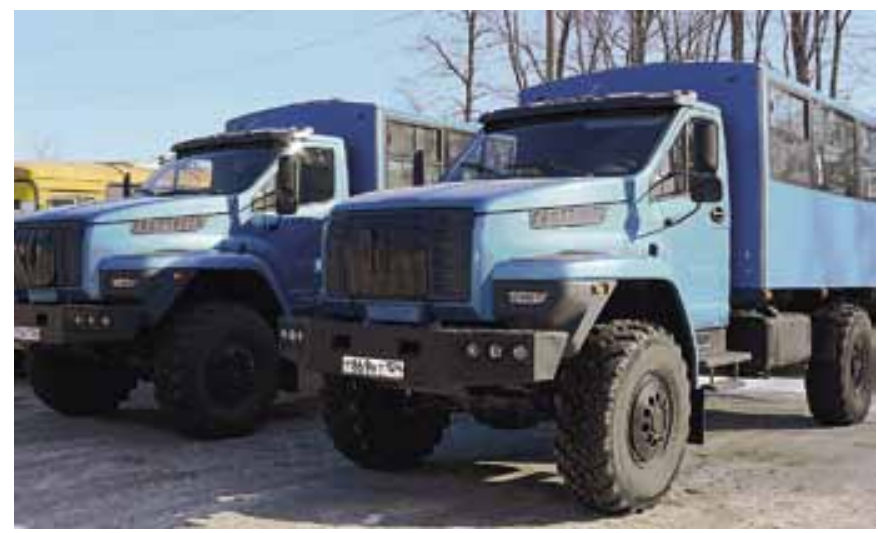

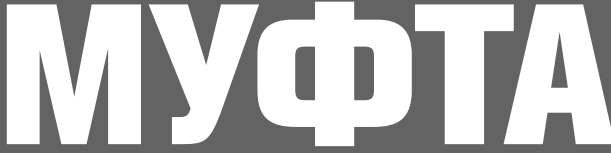

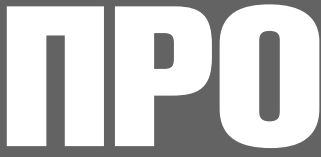

\section{Мы предлагаем:}

- Системы для заправки карьерной техники

- Краны топливозаправочные

- Заправочные клапаны

- Вентиляционные клапаны

- Системы учёта топлива SAMPI S.p.A.

- АЗС, мобильные топливные блоки и автотопливозаправщики со скоростью до 1500 л/ минуту

\section{KoHtakTbl:}

ООО «МУФТА ПРО» тел.: +7 (499) 3946660 e-mail: muftapro@gmail.com www.muftapro.ru www.muftapro.com

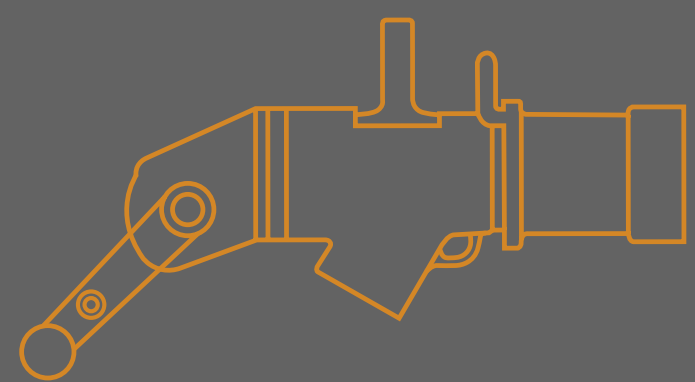

FAST FILL SYSTEMS

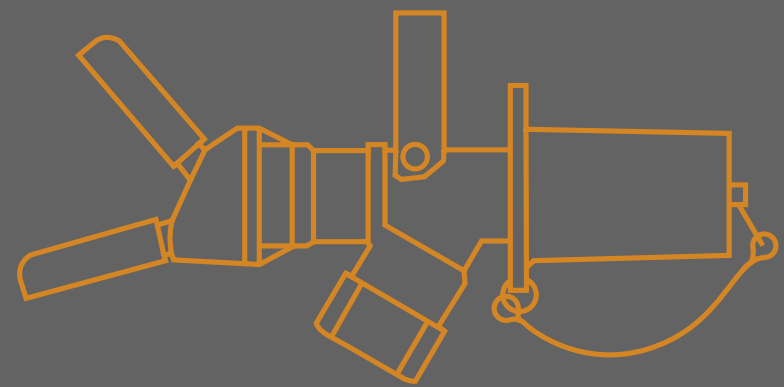

WIGGINS

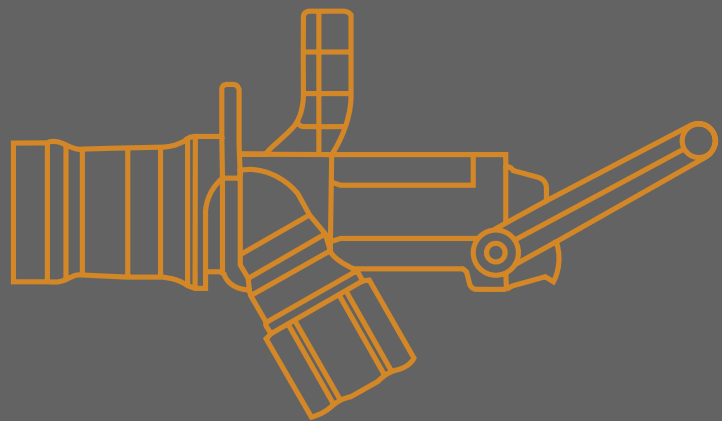

FLOMAX 


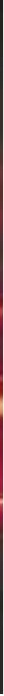

\title{
MAN определяет дальнейшее развитие в России
}

\author{
В марте 2018 г. в г. Москве проила ежегодная пресс-конференция, на которой \\ компания MAN подвела итоги 2017 года и определила стратегические направ- \\ ления дальнейшего развития в России.
}

По итогам 2017 года на рынке коммерческого транспорта в России был достигнут третий в истории статистики результат: по данным аналитических агентств, было реализовано 71,1 $(80,2)$ тыс. новых грузовых автомобилей. Благодаря реализации отложенного спроса, доверию российских клиентов и качественной работе компания ООО «МАНТрак энд Бас РУС» завершила 2017 г. с достойными результатами. Продажи грузовых автомобилей MAN выросли более чем в 2 раза с аналогичным периодом 2016 г. Реализация новых автобусов марки MAN и Neoplan выросла на 76,5\% по результатам 2017 г. Ведущий производитель грузовых автомобилей, автобусов и двигателей подтвердил свое лидерство в традиционно ключевых сегментах.

Традиционно грузовой автомобиль MAN TGS стал лидером продаж в линейке грузовых автомобилей MAN. 3а 2017 г. в России было реализовано более 3 тыс. новых автомобилей MAN TGS. Значительный вклад в этот результат вносят магистральные тягачи TGS 28.360 6×2. За период с 2006-2017 гг. было разработано более 15 модификаций сцепки. Грузовой автомобиль MANTGS 6×2 стал флагманом в сфере дистрибуции с самым высоким коэффициентом технической готовности в отрасли.

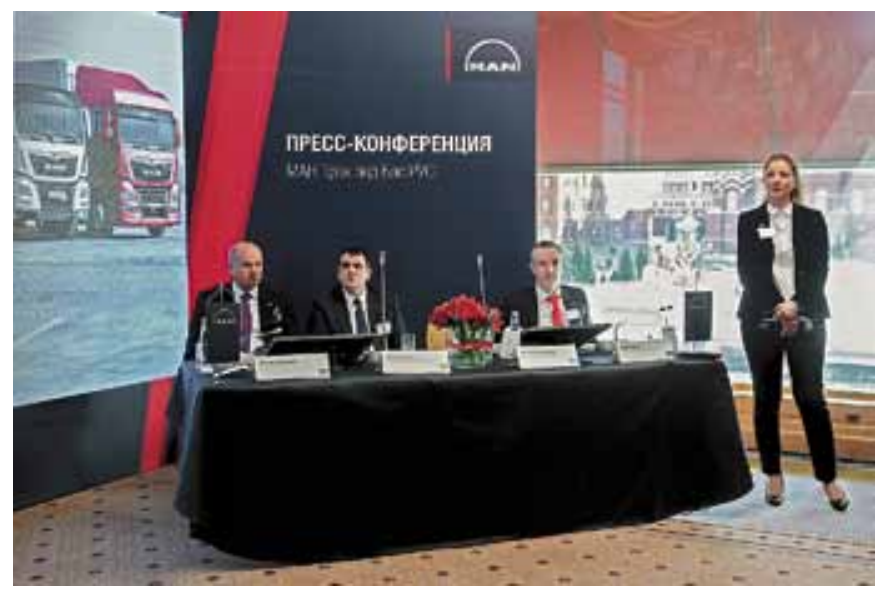

Модельный ряд MAN остается самым популярным во многих сегментах, обеспечивая компании выигрышные позиции на российском рынке. По итогам 2017 года компания лидирует в сегменте грузовиков с колесной формулой $6 \times 6$ (доля рынка составляет 48\%) и 8х8 (доля рынка составляет 78\%). Таким образом, среди европейских брендов немецкий производитель является ведущим поставщиком строительной техники.

«МАН Трак энд Бас РУС» - один из ведущих поставщиков комплексных решений для бизнеса в сфере коммерческого транспорта. Благодаря широкой сети авторизованных сервисных станций (54 партнера) в ключевых регионах России клиенты компании MAN получили возможность воспользоваться комплексными услугами, которые помогают оптимизировать затраты на владение и эксплуатацию техники. Высокий уровень знаний и компетенций российских сервисных специалистов получил мировое признание и позволяет оказывать услуги качественно и на самом высоком уровне. Своевременное сервисное и техническое обслуживание грузовых парков с использованием оригинальных запасных частей MAN - важнейшая составляющая надежности седельных тягачей MAN ceрии TG и фундамент успешной работы любой транспортной компании в России.

В 2018 г. компания ООО «МАН Трак энд Бас РУС» пройдет следующий этап на пути к лидерству на рынке коммерческого транспорта в России. Занимая отличные исходные позиции, имея четкую стратегию, план развития продуктов и сильный бренд, компания может достичь еще большего и завоевать 25\% рынка. Партнерство с Группой ГАЗ - одним из крупнейших автомобильных концернов в России - может в значительной степени способствовать долгосрочному успеху на российском рынке коммерческого транспорта.

В июне 2017 г. Volkswagen Truck \& Bus и Группа ГАЗ подписали Соглашение о сотрудничестве, чтобы оценить возможности стратегического партнерства. Сегодня рассма- 
триваются возможности многочисленных совместных проектов. Первым будет реализован проект по поставке Группе ГАЗ дизельных двигателей VW. MAN также является деловым партнером Группы ГАЗ, поставив 6 тыс. двигателей для городских автобусов.

\section{«Доверительноесо-} трудничество с Группой ГАЗ в автобусном сегменте мы намерены продолжить и в сегменте грузовых автомобилей, чтобы укрепить наши позиции на российском рынке», - говорит генеральный директор ООО «МАН Трак энд Бас РУС» Питер Ан-

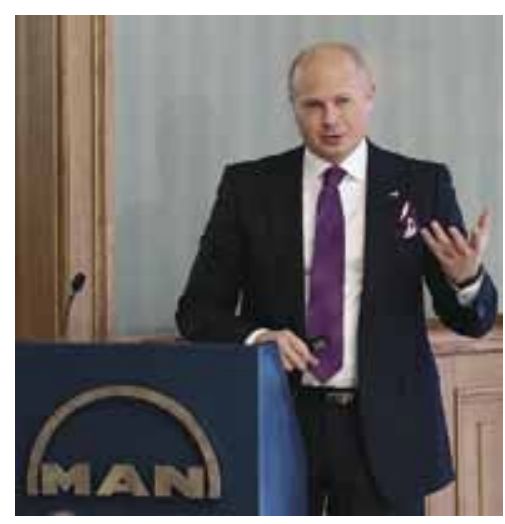

дерссон. Классическая выигрышная ситуация - особенно учитывая тот факт, что российский рынок продолжает восстанавливаться.

Важные тенденции, такие как альтернативные приводы, урбанизация, дигитализация и другие, оказывают сильное влияние на продукты MAN, меняя бизнес-модели и требования клиентов. Современный темп жизни требует от транспортных компаний еще большей гибкости, мобильности и инновационных подходов. Определить новые сферы деятельности и своевременно направить компанию в нужное русло - в этом заключается одна из главных задач компаний в отрасли коммерческого транспорта.

«Используя многолетний опыт, нам удалось создать уникальное предложение, и сегодня мы выводим на рынок новую услугу аренды грузовых автомобилей MAN с достаточно выгодными условиями на рынке. С 1 марта 2018 г. грузовые автомобили MAN предоставляются в аренду на условиях «все включено», т.е. затраты на содержание автомобиля - страховка, обслуживание и ремонт уже входят в стоимость услуги. В рамках стратегии 2020 годамы последовательно работаем над решением новых задач в грузовой логистике. Только так можно добиться большего успеха для наших клиентов и для MAN», - рассказывает Питер Андерссон.

Предприятия, у которых транспорт не является профильным активом, логистические и транспортные компании основная целевая аудитория новой услуги аренды от компании MAN. Предлагаются два варианта грузовых автомобилей, которые можно взять в аренду - седельные тягачи MANTGX 18.400 и MANTGX 18.440. Аренда 400-сильного седельного тягача обойдется в 147007 руб. в месяц с НДС, более мощный 440-сильный вариант обойдется в 153779 руб.

Отличительной особенностью нового комплексного предложения компании MAN является отсутствие аванса (аванс = 0\%). Другими словами, клиент получает грузовой автомобиль MAN без первоначальных инвестиций. Комиссия за оформление сделки также составляет 0\%. Это означает, что за рулем легендарного грузового автомобиля MAN может оказаться больше новых клиентов.

Арендованные автомобили MAN поставляются в комплекте с договором полного сервисного обслуживания ComfortSuper. Клиенту необходимо только предоставить автомобиль на авторизованную сервисную станцию MAN, согласно заранее утвержденному графику. Фиксированный платеж за сервисное обслуживание, независимо от фактически требуемого объема работ, уже включен в стоимость общего арендного контракта.

«Выбор MAN TGX для акции был неслучайным. Благодаря новой услуге аренды без первоначального взноса премиальный грузовой автомобиль марки MAN станет доступен большему числу клиентов», добавляет коммерческий директор ООО «МАН Трак энд Бас РУС» Павел Селев.

Легендарный грузовой автомобиль MAN TGX - лучшее решение для транспортиров-

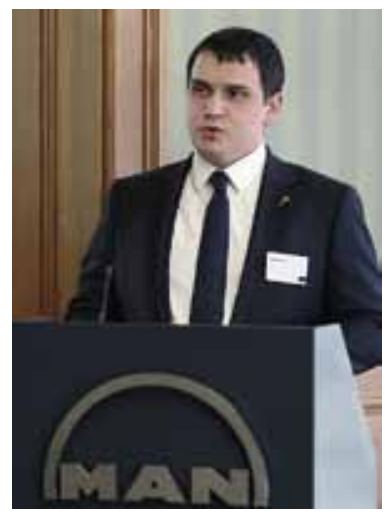
ки грузов на дальние расстояния! Задает ориентир высочайшего уровня топливной эффективности, надежности и экономичности, в том числе благодаря работе двигателей стандартов Евро-5. Он обеспечивает оптимальную грузоподъемность и 100\%-ную совместимость с современными полуприцепами. Большая мощность, идеальная управляемость и совершенный дизайн как интерьера, так и экстерьера не оставят равнодушными ни водителя, ни собственника бизнеса.

ООО «МАН Трак энд Бас РУС» - 100\%-ное дочернее предприятие MAN Truck \& Bus AG, генеральный импортер продукции MAN в России. Предприятие имеет два собственных филиала: в Подольске и Санкт-Петербурге. «МАН Трак энд Бас РУС» работает по всей России через партнерскую сеть, насчитывающую более 50 станций в ключевых регионах страны. MAN предлагает не только услуги по финансированию сделок от компании Volkswagen Financial Services RUS (ООО «Фольксваген Финансовые Услуги РУС»), но и качественный профессиональный сервис. Клиенты компании также имеют возможность приобретать оригинальные запчасти MAN с гарантией 2 года, обслуживать технику в рамках сервисных контрактов, проходить курсы повышения квалификации водителей MAN ProfiDrive, a также пользоваться услугой круглосуточной помощи (выездной сервис и эвакуация) на дорогах Mobile24.

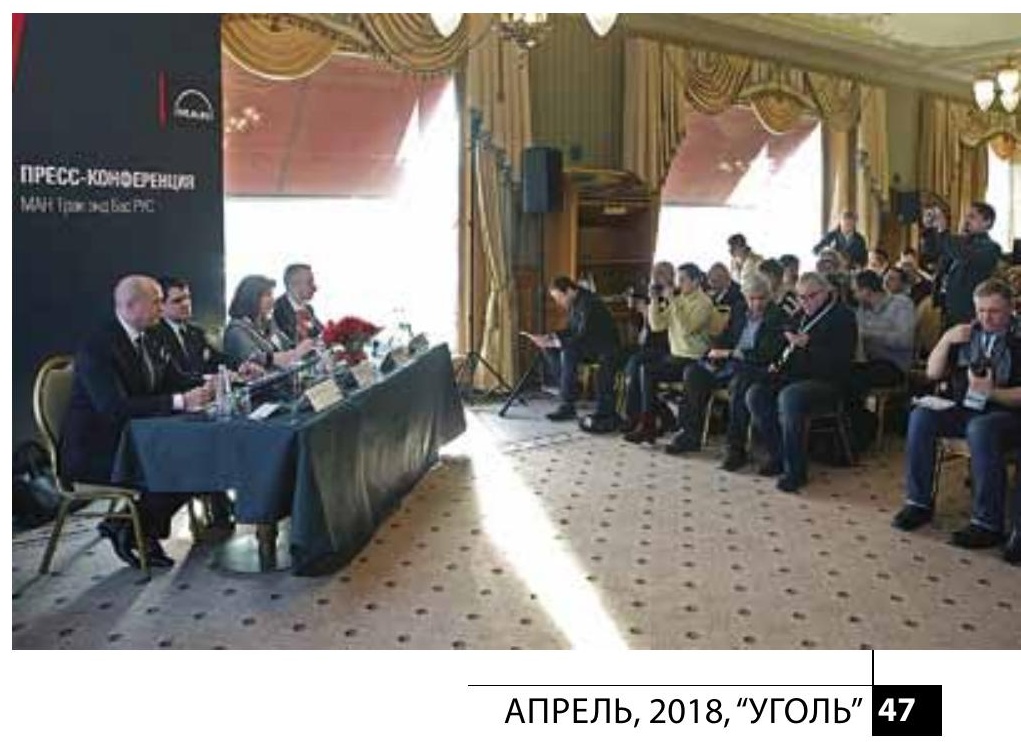




\section{Весовой контроль автотранспорта}

В статье представлена информация о Корпорации «АСИ» (г. Кемерово) - российском разработчике и производителе промышленных электронных весов и систем учета на базе весоизмерительного оборудования. Рассказывается об ассортименте выпускаемой продукции, выполняемых работах и услугах, приводятся примеры реализованных проеКТОВ.

Ключевые слова: весовой учет, автомобильные весы, весоизмерительное оборудование, дорожный весовой контроль.

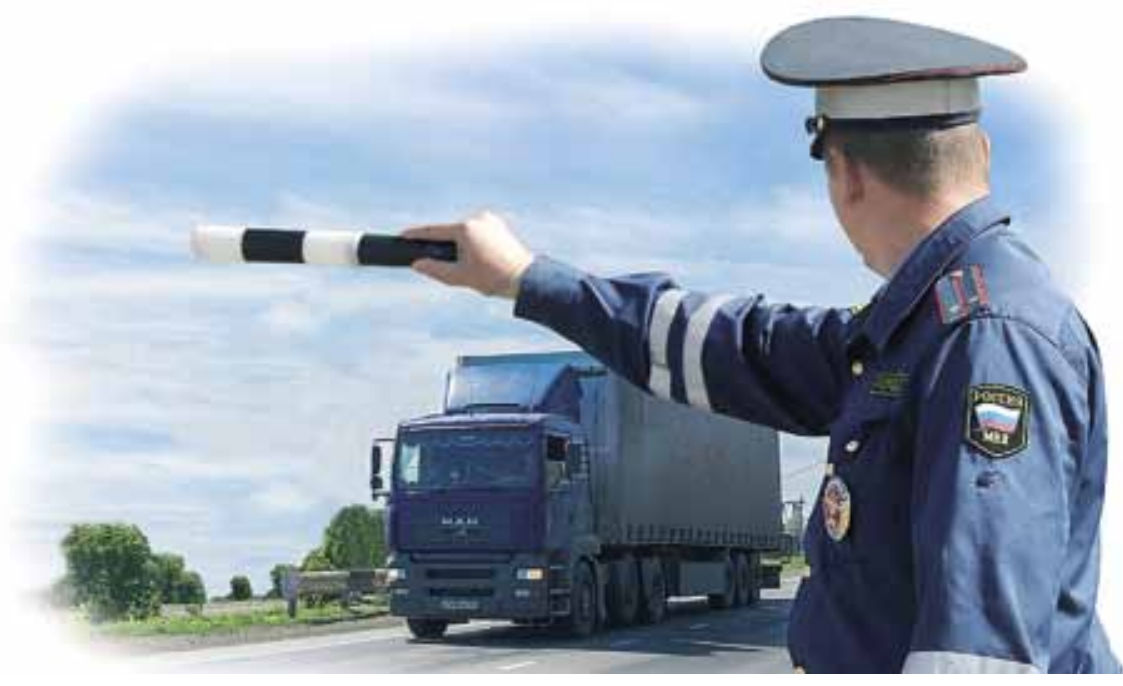

Корпорация «АСИ» - ведущий отечественный разработчик и производитель промышленного весоизмерительного оборудования и автоматизированных систем весового учета и контроля.

Начав свою деятельность в 1991 г. в качестве инжиниринговой компании, Корпорация «АСИ» выросла в крупное предприятие полного производственного цикла, выпускающее десятки наименований весового и метрологического оборудования и оказывающее весь комплекс услуг: разработку проектной и конструкторской документации, проектирование и внедрение систем автоматизации и контроля, строительство объекта «под ключ», поверку средств измерений и сервисное обслуживание.

Ассортимент серийно выпускаемой продукции позволяет решать широкий круг задач весового учета и контроля:

- оборудование для взвешивания транспортных средств (вагонные и автомобильные весы);

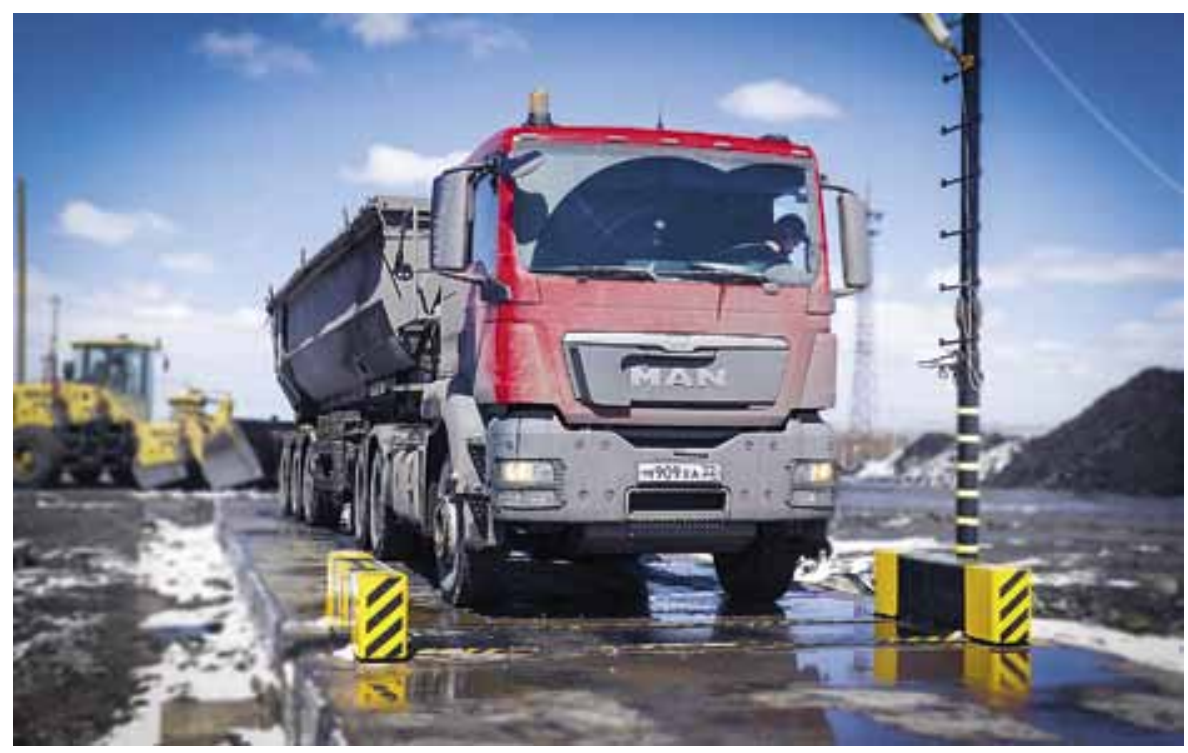

Система контроля осевых нагрузок на $3 A O$ «Шахта Беловская»
- весовая техника для решения технологических задач (конвейерные, крановые, рольганговые, платформенные весы, весодозирующие системы);

- метрологическое и весоповерочное оборудование (компараторы массы, гири классов F и M, весоповерочные тележки, весоповерочные вагоны, мобильные весоповерочные лаборатории, специализированные средства поверки).

За четверть века работы на рынке весостроения Корпорация «АСИ» приобрела большой опыт комплексного оснащения весоизмерительной техникой предприятий горнодобывающей и топливно-энергетической отраслей.

Одним из главных направлений деятельности Корпорации «АСИ» как ведущего производителя весового оборудования является внедрение технологий весового контроля автотранспорта.

В настоящее время перед государством стоит задача совершенствования системы весового контроля с целью недопущения движения транспортных средств со сверхнормативными нагрузками по автомобильным дорогам общего пользования. Превышение предельно допустимой общей массы либо предельно допустимой нагрузки на ось транспортного средства - один из главных факторов, негативно влияющих на сохранность автомобильных дорог.

Крупные предприятия и автохозяйства, ответственно относящиеся к соблюдению требований законодательства по весовому и габаритному контролю, инвестируют средства в развитие весового хозяйства, внедряя актуальные решения. 


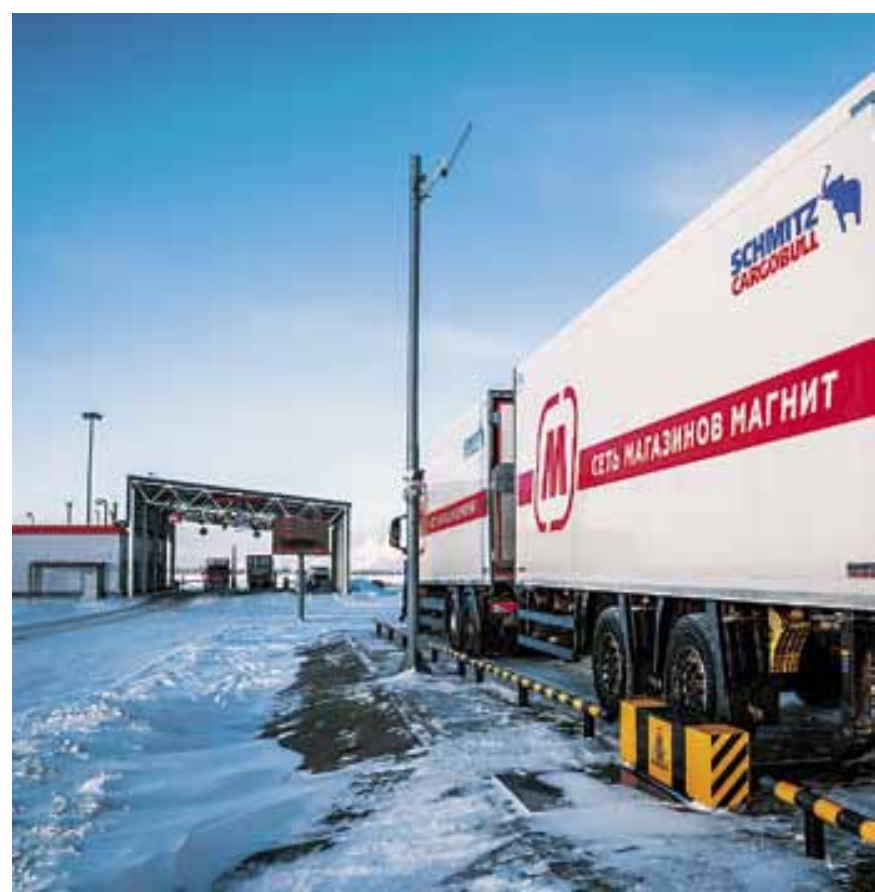

Автомобильные весы «АВТОПОСТ-Д» производства Корпорации «АСИ» - это весы нового поколения, обеспечивающие точный и полный весовой контроль автотранспорта для предотвращения вреда, наносимого дорогам большегрузными автомобилями.

Весы «АВТОПОСТ-Д» предназначены для определения полной массы транспортного средства вместе с грузом, а также нагрузок на отдельные оси и группы осей в движении.

При больших грузопотоках весы оснащаются системой видеонаблюдения и распознавания номеров автомобилей, позволяющей автоматизировать сбор и обработку информации, что способствует сокращению временных затрат на устранение перегруза и при оформлении документации.

Для организации движения и осуществления автоматического взвешивания весы оборудованы системой управления на базе светофоров.

В весовой зоне устанавливается выносное графическое табло для отображения данных об осевых нагрузках и их соответствии нормам. В случае если осевая нагрузка превышает предельно допустимое значение, информация о соответствующей оси отображается на табло в виде мигающих цифр. Этот сигнал сообщает водителю о необходимости перераспределения груза. Данные значения индицируются на табло до момента взвешивания следующего автомобиля.

Специальное клиентское приложение для смартфона позволяет пользователям получать автоматические уведомления о результатах измерений, возможно настроить

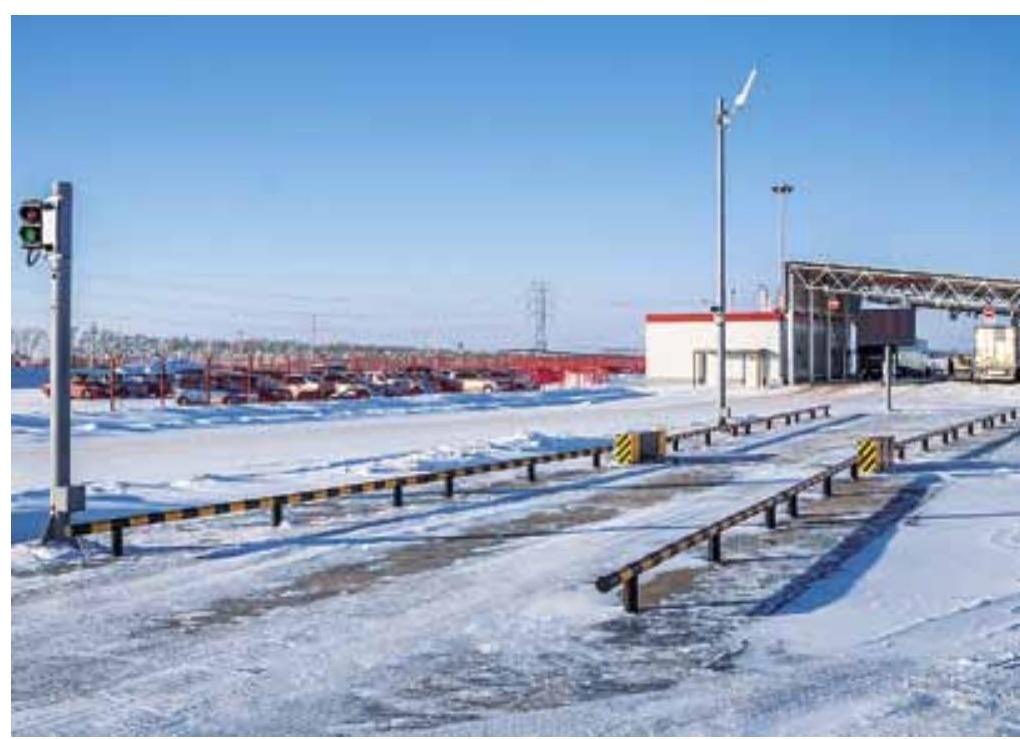

Весы «АВТОПОСТ-Д» установлены более чем в 30 распределительных центрах розничной сети «МАГНИТ» в разных регионах России

рассылку уведомлений по электронной почте и на мобильные мессенджеры.

Измерение полной массы и осевых нагрузок транспортного средства перед выездом на рейс - отличная профилактика штрафов, и современный весоизмерительный комплекс, позволяющий контролировать возможность перегруза, очень востребован на сегодняшний день у предприятий различных отраслей промышленности и транспорта.

TRANSPORT

UDC 656.13:681.264.3 ๑ “ASI” Corporation, 2018

ISSN 0041-5790 (Print) • ISSN 2412-8333 (Online) •

Ugol' - Russian Coal Journal, 2018, № 4, pp. 48-49

\section{Title}

\section{WEIGHT ESTIMATE SYSTEMS OF TRUCK}

\section{Author}

"ASI" Corporation, Kemerovo, 650000, Russian Federation, e-mail: office@icasi.ru

\section{Abstract}

The article presents the information about "ASI" Corporation (Kemerovo) the Russian company for development and production of the industrial electronic scales and weight-measurement equipment-based weighting systems. It narrates about the company product mix, performed activities and services, gives examples of the completed projects.

\section{Keywords}

Weight estimate, Truck scales, Coal loading, Weight measurement equipment.

\section{Корпорация «АСИ»}

650000, г. Кемерово,

ул. Кузбасская, д.31

Тел./факс: +7 (3842) 36-61-49,

+7 (3842) 36-55-01

e-mail: office@icasi.ru www.icasi.ru

\section{Филиал «АСИ-Москва»}

107392, г. Москва,

ул. Малая Черкизовская, д.22

Тел.: +7 (499) 785-52-97,

факс: +7 (499) 785-52-96

e-mail: moscow@icasi.ru

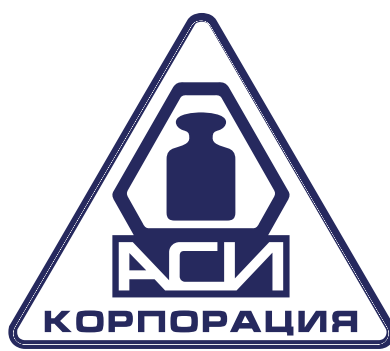




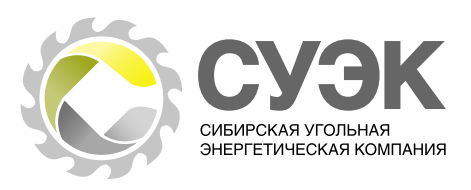

Мурманский морской торговый порт

и Администрация

города-героя Мурманска

подписали Соглашение

- сотрудничестве

\begin{abstract}
5 марта 2018 2. состоялось подписание Соглашения о сочиальноэкономическом сотрудничестве между Администраций города Мурманска и ПАО «Мурманский морской торговый порт». В черемонии приняли участие депутат Государственной Думы Федерального Собрания Российской Федерации Алексей Веллер, глава администрации заполярной столицы Андрей Сысоев и генеральный директор Мурманского ПАО «ММТП» Александр Масько.
\end{abstract}

Соглашение - это не просто закрепление большой совместной работы, которая проводится градообразующим предприятием и муниципалитетом. Документ позволяет сделать это взаимодействие системным, сконцентрировать совместные усилия на решении насущных проблем, вырабатывать согласованную политику, направленную на всестороннее развитие областного центра.

«Исторически сложилось, что город-герой Мурманск идет рука об руку с торговым портом. Это современное, динамично развивающееся предприятие, дающее северянам тысячи рабочих мест. Уверен, сегодняшняя встреча станет еще одним шагом к более тесному сотрудничеству», - подчеркнул депутат Государственной Думы Федерального Собрания Российской Федерации Алексей Веллер.

«Этот документ важен не только для предприятия, но и для города. В скором времени мурманчане смогут оченить новые результаты нашей совместной деятельности, - отметил глава Администрации города Мурманска Андрей Сысоев. - Важно, что Мурманский морской торговый порт продолжает оказывать поддержку в решении сочиально-экономических вопросов и реализачии городских проектов».

«В недавнем послании Федеральному собранию Президент России предложил развернуть масштабную программу пространственного развития России. При этом он отметил важность сохранения у российских городов своего лица и исторического наследия. Это относится и к Мурманску, который более 100 лет назад создавался именно как город-порт. Причалы и портальные краны торгового порта уже давно стали неотъемлемой чертой архитектурного и исторического облика столицы Кольского Заполярья. Объединяя усилия с городской администрацией, мы бы хотели всемерно поддержать работу по сохранению этого исторического облика и совместно реализовать программу по интеграции портовой инфраструктуры в современную городскую среду», - рассказал на церемонии подписания Соглашения генеральный директор ПАО «ММТП» Александр Масько.

ПАО «Мурманский морской торговый порт» - крупнейшая стивидорная компания Арктического бассейна, ежегодно перечисляющая в бюджеты всех уровней порядка 1 млрд руб. налоговых платежей.

Особый импульс сотрудничество областного центра с градообразующим предприятием получило в период подготовки и празднования 100-летия порта и города. Тогда во взаимодействии с муниципалитетом был реализован целый комплекс социальных инициатив: реконструирован сквер у морского вокзала, проведены работы по обновлению площадки возле памятника Анатолию Бредову.

Ежегодно портовики принимают участие в акции «Зеленый рекорд». Предприятие активный участник городской программы «Теплое окно». На базе гимназии № 8 по инициативе Мурманского морского торгового порта создан единственный в России профильный портовый транспортно-логистический класс.

Тесное взаимодействие муниципальных властей с администрацией ПАО «ММТП» дает видимые результаты, является примером координации усилий для успешной реализации программ развития самого большого заполярного города в мире. 


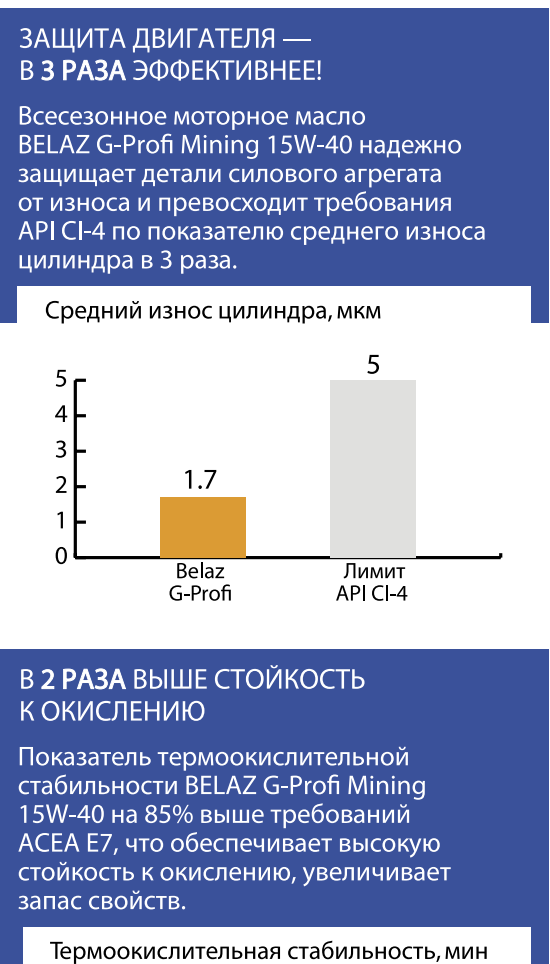

Термоокислительная стабильность,мин
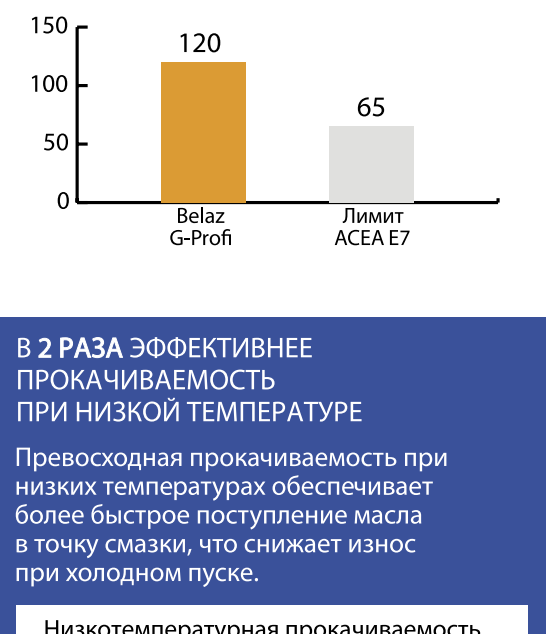

Низкотемпературная прокачиваемость при $-25^{\circ} \mathrm{C}, \mathrm{м} \Pi \mathrm{a} \cdot \mathrm{C}$

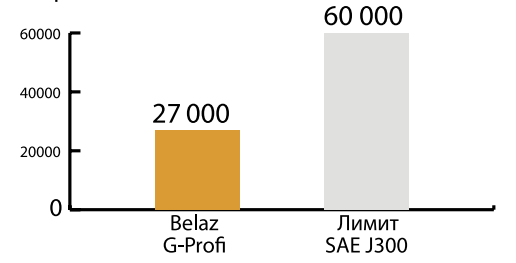

ОРИГИНАЛЬНЫЕ ТРАНСМИССИОННЫЕ МАСЛА СЕРИИ ВELAZ G-PROFI TRANS ГАРАНТИРУЮТ ПОВЫШЕННУЮ ЗАЩИТУ ОТ ИЗНОСА

Специализированный пакет присадок для трансмиссионных масел BELAZ G-Profi Trans разработан с учетом материалов сальников и уплотнений, обеспечивая прекрасную совместимость. Стабильная масляная пленка на деталях трансмиссии предотвращает повышенное изнашивание трущихся поверхностей в тяжелых условиях эксплуатации при высоких, в том числе ударных нагрузках.
При разработке серии трансмиссионных масел BELAZ G-Profi Trans учитывали жесткие температурные режимы эксплуатации редукторов мотор-колес и иных элементов трансмиссии карьерных самосвалов БЕЛАЗ. В результате была обеспечена высокая термическая стабильность, препятствующая образованию отложений на рабочих поверхностях трансмиссии.

\section{ОРИГИНАЛЬНЫЕ ГИДРАВЛИЧЕСКИЕ МАСЛА СЕРИИ BELAZ G-PROFI HYDRAULIC ИДЕАЛЬНО СОВМЕСТИМЫ С МАТЕРИАЛАМИ ГИДРООБОРУДОВАНИЯ}

Одной из главных систем самосвала БЕЛАЗ, передающей и распределяющей усилия, является гидравлическая система, к гидравлическим маслам которой предъявляются широкие требования. Прежде всего это совместимость с различными металлами и эластомерами, что гарантирует высокую надежность работы оборудования. Благодаря вовлечению специальных противоизносных компонентов удалось значительно увеличить ресурс шестеренчатых, лопастных, радиальных и аксиально-поршневых насосов. При производстве масел BELAZ G-Profi Hydraulic используют высококачественные загущающие присадки, которые обеспечивают высокий индекс вязкости. Таким образом, масла BELAZ G-Profi Hydraulic можно использовать в широком диапазоне температур, что позволяет эксплуатировать технику БЕЛАЗ в любых климатических зонах. Высокие деэмульгирующие свойства обеспечивают стабильность работы гидросистемы В присутствии воды, а минимальное время деаэрации исключает сжимаемость масла, что улучшает его смазывающие и охлаждающие способности. Высокий класс чистоты и превосходная фильтруемость позволяют продлить срок службы оборудования.

\section{ОХЛАЖДАЮЩИЕ ЖИДКОСТИ CEРИИ BELAZ G-PROFI ANTIFREEZE РАЗРАБОТАНЫ СПЕЦИАЛЬНО} ДЛЯ ТЕХНИКИ БЕЛАЗ

От качества охлаждающей жидкости и соблюдения правил эксплуатации зависит долговечность и надежность работы двигателя, поэтому все крупнейшие мировые производители двигателей предъявляют жесткие требования к охлаждающим жидкостям и требуют их неукоснительного соблюдения. В полной мере это относится к силовым агрегатам, устанавливаемым на автомобили БЕЛАЗ

Основной проблемой, связанной с применением охлаждающих жидкостей в тяжелонагруженных двигателях, является кавитация гильз. Кавитация способна за 2000 часов работы двигателя создать сквозные отверстия в гильзе, что неизбежно приведет
В 2 РАЗА МЕНЬШЕ ИЗНОС

Благодаря стойкой пленке

в точке контакта трансмиссионные

масла серии BELAZ G-Profi Trans

существенно снижают износ

трущихся поверхностей.

Противоизносные свойства ASTM D6121, балл

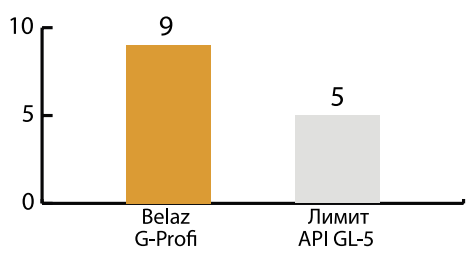

В 3 РАЗА ВЫШЕ ТЕРМИЧЕСКАЯ

СТАБИЛЬНОСТЬ

Показатель термической стабильности

серии масел BELAZ G-Profi Trans

на $70 \%$ выше требований API GL-5,

что существенно снижает образование

отложений на парах трения.

Термическая стабильность ASTM D5704,\%

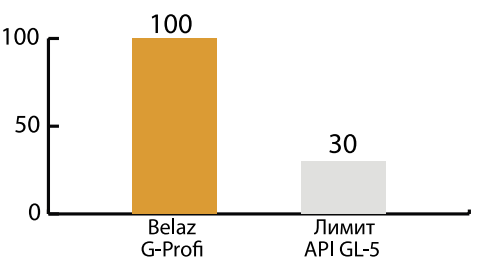

к капитальному ремонту или даже к списанию агрегата. Возникающие при этом затраты несоизмеримо больше, чем расходы на закупку охлаждающей жидкости

Охлаждающие жидкости серии BELAZ G-Profi Antifreeze содержат антикавитационные пакеты присадок, снижающие скорость кавитационного разрушения гильз в 10-20 раз по сравнению с обычными антифризами. На иллюстрации приведены две гильзы, отработавшие в аналогичных условиях: с обычной охлаждающей жидкостью (рис. слева) и с жидкостью, имеющей антикавитационный пакет присадок (рис. справа). На гильзе слева отчетливо видны кавитационные «ямы», причем некоторые из них имеют сквозной характер.

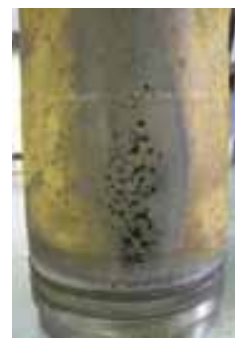

В систему охлаждения была залита универсальная охлаждающая жидкость - отчетливо видны разрушения гильзы, вызванные кавитацией

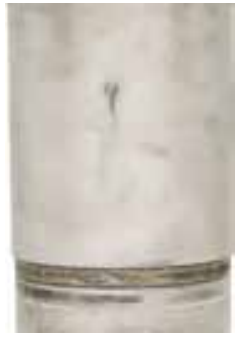

Гильза двигателя, который работал с оригинальной охлаждающей жидкостью, имеющей антикавитационные присадки 
ОРИГИНАЛЬНАЯ ОХЛАЖДАЮЩАЯ ЖИДКОСТЬ BELAZ G-PROFI ANTIFREEZE RED

Предназначена для применения в двигателях европейских производителей MTU и Deutz. По своему составу она относится к карбоксилатному (ОАТ) типу, обеспечивает долговременную и эффективную защиту от коррозии и кавитации “мокрых» гильз. Имеет официальный допуск от MTU на ее применение с рекомендованным сроком эксплуатации 9000 м/ч, или 3 года.

\section{ОРИГИНАЛЬНАЯ ОХЛАЖДАЮЩАЯ ЖИДКОСТЬ BELAZ G-PROFI ANTIFREEZE GREEN}

Предназначена для применения в двигателях Cummins и ЯМЗ. Содержит в своем составе полный пакет присадок, соответствует спецификациям Cummins CES 14603, ASTM D6210. Имеет официальный допуск от ЯМЗ на ее применение. Совместима с дополнительными присадками DCA-2, DCA-4, а также с фильтрами охлаждающей жидкости Fleetguard. BELAZ G-Profi Antifreeze Green обеспечивает эффективную защиту от коррозии и кавитации благодаря использованию специальных ингибиторов коррозии, включая нитриты. Срок эксплуатации - в соответствии с рекомендациями Cummins и ЯМЗ.

\section{РЕГУЛЯРНЫЙ КОНТРОЛЬ КАЧЕСТВА}

Регулярное проведение подтверждающих испытаний под контролем НТЦ ОАО «БЕЛАЗ», а также внедрение специальных методов контроля качества при производстве смазочных материалов гарантируют высокий уровень эксплуатационных характеристик продуктов профессиональной линейки BELAZ G-Profi, а значит - уверенность эксплуатирующих организаций в надежной работе карьерной техники БЕЛАЗ.

\section{ЭКОНОМИЧЕСКИЙ ЭФФЕКТ}

Использование оригинальных масел BELAZ G-Profi позволяет сократить износ оборудования, что ведет к снижению простоев на ремонт, существенному сокращению финансовых потерь и, как следствие, росту рентабельности производства.

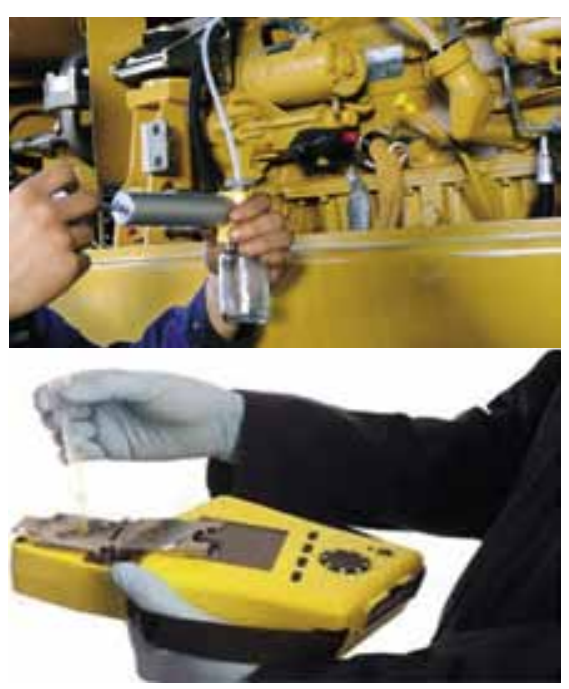

Экономия на стоимости масла и охлаждающей жидкости несоизмерима с затратами на ремонт техники и с потерями от ее простоя. Для производства продуктов профессиональной линейки BELAZ G-Profi используются только качественные базовые компоненты и современные высокоэффективные пакеты присадок, позволяющие максимально продлить ресурс техники и увеличить КТГ (коэффициент технической готовности].

Дилеры ОАО «БЕЛАЗ» при участии производителя оригинальных смазочных материалов и специальных жидкостей готовы предоставить потребителю квалифицированную техническую поддержку по единому стандарту
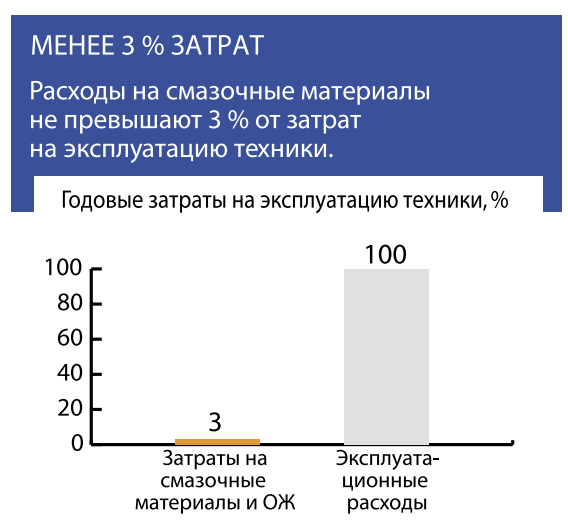

OTS BELAZ при условии использования продукции BELAZ G-Profi.

\section{ОРИГИНАЛЬНЫЕ МАСЛА}

BELAZ G-PROFI ИЛИ УНИВЕРСАЛЬНАЯ АЛЬТЕРНАТИВА - ЧТО ВЫГОДНЕЕ?

Стремление к экономии при эксплуатации карьерной техники порой является основанием для закупки и применения организацией неоригинальных запасных частей, расходных и смазочных материалов. Универсальные масла для коммерческого транспорта не являются лучшим решением для карьерной техники ввиду того, что карьерные самосвалы работают в совершенно иных, более жестких условиях. Кроме того, при возникновении эксплуатационной ситуации в условиях применения нерекомендованных эксплуатационных материалов, получение оперативной технической поддержки от производителя может быть осложнено. Также нередки случаи, когда закупленная продукция известных мировых и российских производителей на поверку оказывается контрафактной

При использовании неоригинальных запчастей и/или эксплуатационных материалов, в том числе смазочных материалов и технических жидкостей, эксплуатирующие организации несут повышенные риски, связанные с вероятностью преждевременного выхода агрегатов из строя, что, в свою очередь, приводит к внеплановому ремонту и непроизводственному простою техники. Как следствие - незапланированные дополнительные расходы, например:

- стоимость капитального ремонта ДВС Cummins QST 30-С карьерного самосвала БЕЛАЗ-75580 - от 5 млн рублей;

- упущенная выгода от непроизводственного простоя одной единицы БЕЛАЗ-75580

- от 600 тыс. рублей в сутки в зависимости от вида добываемого полезного ископаемого.

\section{ИМЕННО РЕКОМЕНДОВАННЫЕ СМАЗОЧНЫЕ МАТЕРИАЛЫ BELAZ G-PROFI ПОЗВОЛЯюТ ПРОДЛИТЬ ЭФФЕКТИВНЫЙ ПЕРИОД ЭКСПЛУАТАЦИИ И РЕСУРС УЗЛОВ И АГРЕГАТОВ ТЕХНИКИ БЕЛАЗ, ЧТО ЯВЛЯЕТСЯ ЗАЛОГОМ ВЫСОКОЙ РЕЗУЛЬТАТИВНОСТИ ДЕЯТЕЛЬНОСТИ ЛЮБОГО ПРЕДПРИЯТИЯ ГОРНОДОБЫВАЮЩЕЙ ОТРАСЛИ.}

\section{ЗАО «ТД «БЕЛАЗ», ЧТО ГАРАНТИРУЕТ ПОКУПАТЕЛЮ ЗАЩИТУ ОТ ПОКУПКИ}

ЛИНЕЙКА ВELAZ G-PROFI PЕАЛИЗУЕТСЯ ЭКСКЛЮЗИВНО ЧЕРЕЗ ДИЛЕРСКУЮ СЕТЬ КОНТРАФАКТА И СНИЖАЕТ СТОИМОСТЬ ВЛАДЕНИЯ ТЕХНИКОЙ

Использование оригинальных смазочных материалов и технических жидкостей BELAZ G-Profi позволяет организациям, эксплуатирующим технику БЕЛАЗ:

\footnotetext{
- быть уверенными в качестве применя мых эксплуатационных материалов

- исключить возможность закупки контрафакта;

- снизить риски возникновения непроизводственных потерь;
}

\author{
- повысить КТГ (коэффициент \\ технической готовности); \\ - бесплатно получать специализи- \\ рованную техническую поддержку \\ и консультации экспертов \\ по программе OTS BELAZ.
}

По вопросам приобретения оригинальных смазочных материалов и технических жидкостей BELAZ G-Profi обращайтесь к официальному представителю БЕЛАЗ:

АО «Горнопромышленная финансовая компания» 107078, г. Москва,

Докучаев пер., д.3, стр.1 ГорнопроМышлЕНная Тел.: +7 (499) 975-10-51; 975-15-95; 975-13-74 e-mail: info@gpfk.ru www.gpfk.ru

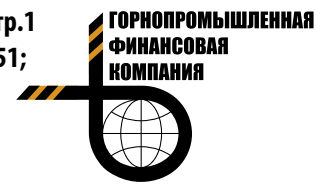




\section{Обоснование расчетных прочностных характеристик горных пород баритового месторождения}

DOI: http://dx.doi.org/10.18796/0041-5790-2018-4-54-59

\section{БЕСИМБАЕВА Ольга Газисовна}

Канд. техн. наук, дочент кафедры

«Маркшейдерское дело и геодезия» КарГТУ,

100027, г. Караганда, Республика Казахстан,

e-mail:bog250456@mail.ru

\section{ХМЫРОВА Елена Николаевна}

Канд. техн. наук, заведующая кафедрой

«Маркшейдерское дело и геодезия» КарГту,

100027, г. Караганда, Республика Казахстан,

e-mail:hmyrovae@mail.ru

\section{ОЛЕНЮК Сергей Петрович}

Канд. техн. наук, старший преподаватель кафердры «Маркшейдерское дело и геодезия» КарГту, 100027, г. Караганда, Республика Казахстан, e-mail:savml@mail.ru

\section{ОЛЕЙНИКОВА Елена Алексеевна}

Магистр техн. наук, старший преподаватель кафедры «Маркшейдерское дело и геодезия» КарГТУ, 100027, г. Караганда, Республика Казахстан, e-mail: panasenkoelena@mail.ru

\section{СТАРОСТИНА Ольга Васильевна}

Канд. техн. наук, дочент кафедры

«Маркшейдерское дело и геодезия» КарГТУ,

100027, г. Караганда, Республика Казахстан,

e-mail: o.starostina@kstu.kz

В статье рассматриваются вопросы обоснования расчетных значений прочностных характеристик горных пород баритового месторождения. Для решения данной научнопрактической задачи были построены паспорта прочности пород по классической схеме, которые отражают физикомеханические свойства горных пород в образце, далее был определен коэффициент структурного ослабления пород $\lambda_{\text {, }}$ учитывающий влияния трещиноватости массива, размеров структурных блоков, влажности горных пород и других факторов и который позволил перейти к прочностным характеристикам пород в массиве. Для оценки принятых расчетных значений прочностных характеристик горных пород в массиве выполнено сравнение результатов их определения по методике ВНИМИ и по компьютерной программе Rocklab. Анализ проведенныхисследований показалхорошую сходимость результатов определения значений прочностныххарактеристик горных пород, которая лежит в пределах 3-5\%, что подтверждает правильность принятых решений. Ключевые слова: прочность пород, одноосное сжатие и растяжение пород, паспорт прочности пород, коэффициент структурного ослабления пород, сцепление и угол внутреннего трения пород.

\section{ВВЕДЕНИЕ}

Для решения научно-практической задачи по обоснованию устойчивости бортов и уступов карьера главным моментом является обоснование расчетных прочностных характеристик горных пород месторождения. По значениям пределов прочности горных пород баритового месторождения на одноосное сжатие и растяжение, определенным по результатам лабораторных испытаний, были построены паспорта прочности пород по классической схеме, которые отражают физико-механические свойства горных пород в образце [1].

Ниже приведен расчетный метод построения паспорта прочности по данным определения пределов прочности при одноосном сжатии и растяжении по ГОСТ 21153.8-88 с построением паспорта прочности.

\section{МЕТОД ПОСТРОЕНИЯ ПАСПОРТА ПРОЧНОСТИ}

Метод предусматривает определение координат точек огибающей кривой расчетным путем, с использованием данных определения пределов прочности при одноосном сжатии и растяжении по эмпирическому уравнению:

$$
\tau=\tau_{\max } \cdot\left(\frac{\sigma_{K}^{2}}{\sigma_{K}^{2}+a^{2}}\right)^{\frac{3}{8}},
$$

где $\tau_{\max }$ - максимальное сопротивление породы срезу (сдвигу) при гипотетически полностью закрывшихся под действием нормального давления трещинах и порах; $\sigma_{K}$ - нормальное напряжение относительно начала координат, перенесенного в точку пересечения огибающей кривой с осью абсцисс; $a$ - параметр формы огибающей кривой.

Для удобства расчетов и табулирования уравнение огибающей переводят в безразмерные координаты $l$ и $K$, связанные соотношением:

$$
l=0,73 \cdot\left(\frac{K^{2}}{K^{2}+1}\right)^{\frac{3}{8}} .
$$

Вводят безразмерные радиусы предельных кругов Мора для одноосного растяжения $q_{1}$ и одноосного сжатия $q_{2}$ и, используя отношение $q_{2} / q_{1}=\sigma_{\text {сж }} / \sigma_{\text {с }}$ последовательно вычисляют:

- значение параметра формы огибающей кривой:

$$
a=\frac{\sigma_{\text {сж }}}{2 q_{2}} ;
$$

- значение параметра переноса начала координат:

$$
\sigma_{0}=a \cdot\left(K_{1}+q_{1}\right)
$$

где $q_{2}$ и $\left(K_{1}+q_{1}\right)$ определяют по подготовленной таблице для соответствующего значения отношения $q_{2} / q_{1}$ (промежуточные значения определяют интерполяцией).

Вычисляют координаты $\sigma$ и $\tau$ отдельных точек огибающей кривой:

$$
\sigma=\sigma_{K}-\sigma_{0}=K \times a-\sigma_{0}, \tau=1 \cdot a .(5)
$$




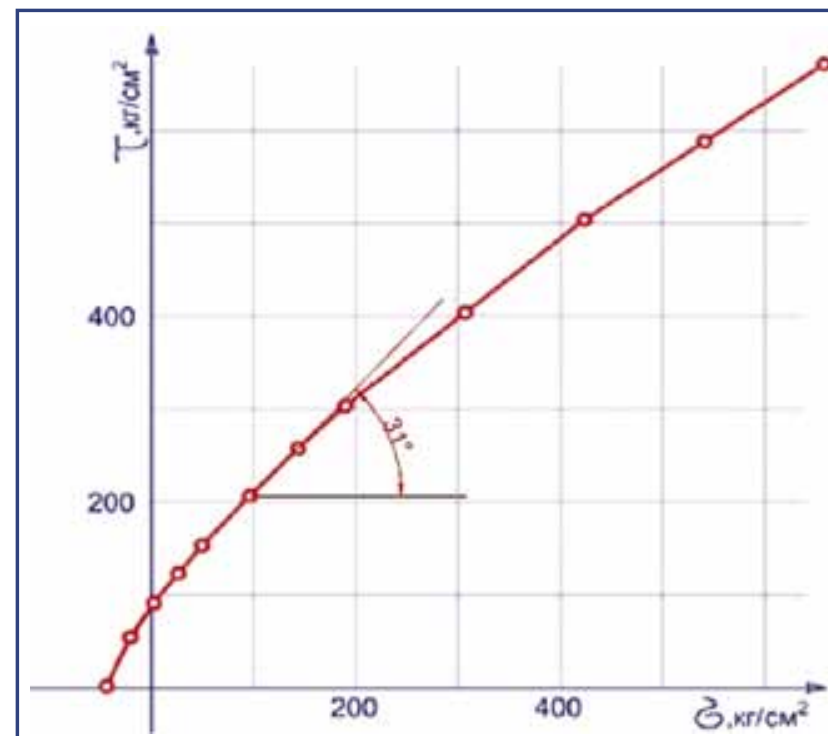

Pис. 1. График огибающей кривой

Fig. 1. Sompound curve chart

По совокупности парных значений $\sigma$ и $\tau$ в координатах $\sigma-\tau$ наносят семейство точек, которые соединяют кривой линией (рис. 1).

Контроль правильности расчетов и построения огибающей выполняют проведением полуокружностей радиусами $\sigma_{\mathrm{p}} / 2$ и $\sigma_{\text {сж }} / 2$ с координатами центров $\left(-\sigma_{\mathrm{p}} / 2 ; 0\right)$ и $\left(\sigma_{\text {сж }} / 2 ; 0\right)$. Если расчеты и построение выполнены правильно, то полуокружности должны коснуться огибающей кривой (рис. 2).

В соответствии с приведенной методикой выполнены построения паспортов прочности основных типов горных пород, слагающих прибортовые массивы карьера. Приведены график огибающей кривой и паспорт прочности для типа породы - известняков от темно-серых до розовато-серых (см. соответственно рис. 1, рис. 2).

Согласно паспорту прочности для известняков от темносерых до розовато-серых предельное сопротивление срезу (сцепление) равно $\tau_{\mathrm{c}}=K_{0}=87 \mathrm{\kappa} / \mathrm{cm}^{2}$, а угол внутреннего трения составляет $\varphi=31^{\circ}$.

Результаты построения паспортов прочности и определения прочностных характеристик горных пород баритового месторождения сведены в табл. 1.

Представленные в табл. 1 прочностные характеристики основных типов горных пород соответствуют характеристикам пород в образце. Для использования их в расчетах по оценке устойчивости откосов уступов и бортов карьера необходимо иметь значения прочностных характеристик в массиве с учетом влияния трещиноватости, размеров структурных блоков, влажности горных пород и других факторов.

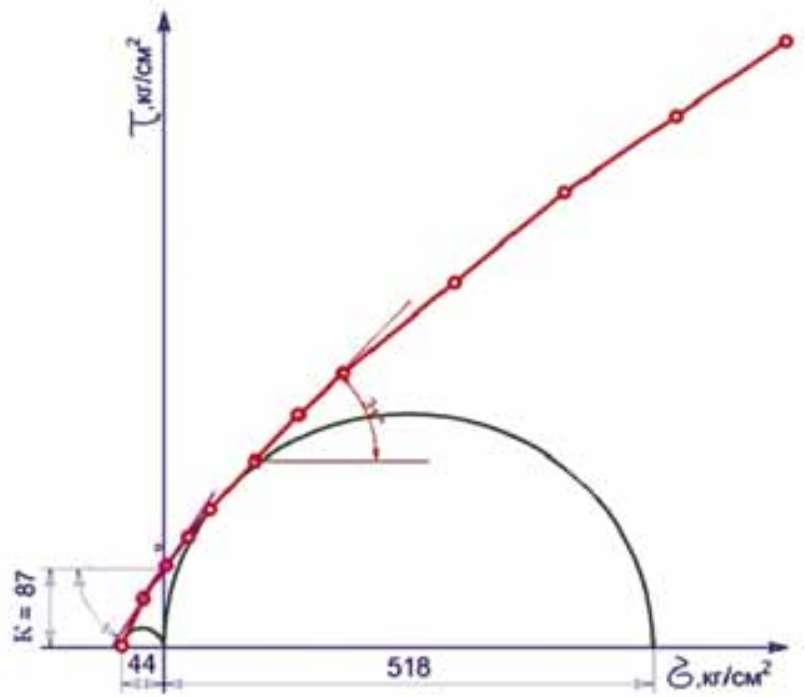

Puc. 2. Пасnорт прочности

Fig. 2. Strength certificate

\section{КОЭФФИЦИЕНТ СТРУКТУРНОГО \\ ОСЛАБЛЕНИЯ ПОРОД $\lambda_{0}$}

Для практического использования физико-механических свойств горных пород, полученных в лабораторных условиях, необходимо знать коэффициент структурного ослабления пород $\lambda_{0^{\prime}}$ который учитывает влияние вышеприведенных факторов на состояние горных пород в массиве.

Трещиноватость горных пород при открытой разработке месторождений оказывает влияние на устойчивость откосов и является ослабляющим фактором, подлежащим учету при решении задач устойчивости и выборе оптимальных средств разрушения трещиноватых сред.

Трещиноватость пород служит основанием для подбора и разработки расчетных методов по определению оптимальных параметров уступов и бортов карьера и позволяет решать задачи по рациональной отработке приконтурных лент и постановке уступов на проектный контур. Поэтому в процессе отработки месторождения необходимо проводить съемку трещиноватости, элементов залегания трещин, линейных элементов структурных блоков, выделение систем трещин, наиболее неблагоприятно ориентированных относительно простирания уступов.

В работе [2] приведена эмпирическая зависимость между сцеплением в образце и массиве при наличии поверхности скольжения, не совпадающей с поверхностями ослабления, из которой была выведена формула расчета коэффициента структурного ослабления пород.

Углы внутреннего трения пород в образце и массиве для одного и того же типа пород отличаются не существенно, поэтому их значения можно принять равными $\rho_{\text {образ }} \approx \rho_{\text {м. }}$.

Таблица 1

\section{Прочностные характеристики горных пород в образце}

\begin{tabular}{|c|c|c|c|c|}
\hline Тип пород & $\sigma_{\mathrm{c} w^{\prime}}, \mathbf{K r} / \mathbf{C M}^{2}$ & $\begin{array}{c}\sigma_{\text {растяж' }} \\
\mathbf{K} / \mathbf{C M}^{2}\end{array}$ & 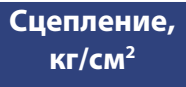 & $\begin{array}{c}\text { Угол внутреннего } \\
\text { трения, градус }\end{array}$ \\
\hline Песчаники трещиноватые выветрелые & 462 & 42 & 80 & 33 \\
\hline Песчаники баритизированные и окварцованные & 789 & 104 & 161 & 30 \\
\hline Известняки темно-серые до розовато-серых иногда слоистые & 518 & 44 & 87 & 31 \\
\hline $\begin{array}{l}\text { Переслаивание песчаника с алевролитами } \\
\text { и углисто-кремнистыми }\end{array}$ & 509 & 95 & 121 & 25 \\
\hline
\end{tabular}


Значение коэффициента $а$ для основных типов пород карьера

\begin{tabular}{|c|c|c|c|c|}
\hline $\begin{array}{l}\text { Группа } \\
\text { пород }\end{array}$ & $\begin{array}{c}\text { Наименование пород } \\
\text { и характер трещиноватости } \\
\text { из методических указаний }\end{array}$ & $\begin{array}{c}\text { Типы пород прибортового } \\
\text { массива баритового } \\
\text { месторождения }\end{array}$ & 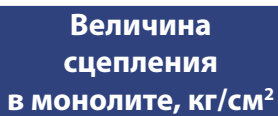 & $\begin{array}{c}\text { Величина } \\
\text { коэффициента } a\end{array}$ \\
\hline III & $\begin{array}{l}\text { Уплотненные песчано-глинистые, } \\
\text { в основном нормально-секущей } \\
\text { трещиноватости }\end{array}$ & $\begin{array}{l}\text { Аральские глины с примесью песка и } \\
\text { галечника }\end{array}$ & $10-20$ & 0,5 \\
\hline II & $\begin{array}{l}\text { Уплотненные песчано-глинистые } \\
\text { с развитой кососекущей } \\
\text { трещиноватостью, каолинизирован- } \\
\text { ные изверженные }\end{array}$ & $\begin{array}{l}\text { Песчаники трещиноватые } \\
\text { выветрелые }\end{array}$ & $30-80$ & 3 \\
\hline \multirow{3}{*}{ II } & Слоистые средней крепости & $\begin{array}{l}\text { Известняки темно-серые, } \\
\text { до розовато-серых, иногда слоистые }\end{array}$ & $100-150$ & 3 \\
\hline & Слоистые средней крепости & $\begin{array}{l}\text { Переслаивание песчаника } \\
\text { с алевролитами и углисто-кремнистыми }\end{array}$ & $100-150$ & 3 \\
\hline & $\begin{array}{l}\text { Слоистые средней крепости } \\
\text { преимущественно нормальносекущей }\end{array}$ & $\begin{array}{l}\text { Песчаники баритизированные } \\
\text { и окварцованные }\end{array}$ & $170-200$ & 4 \\
\hline
\end{tabular}

Сцепление пород, полученное по паспортам прочности, может быть в десятки раз больше, чем для той же породы в массиве. Согласно исследованиям ВНИМИ, эти величины связаны между собой коэффициентом структурного ослабления $\lambda_{0}$, который может быть определен по формуле:

$$
\lambda_{0}=\frac{1}{1+a \ln \frac{H}{l}},
$$

где $a$ - коэффициент, зависящий от прочности породы в монолитном образце и характера трещиноватости; $\frac{H}{l}-$ отношение глубины залегания пород к среднему размеру элементарных блоков.

Коэффициент структурного ослабления пород определяется относительной величиной интенсивности трещиноватости массива. Величина коэффициента $a$ определяется из «Методических указаний по наблюдениям за деформациями бортов, откосов уступов и отвалов на карьерах» по величине сцепления и характеру трещиноватости, значения которых для разных типов пород приведены в работах [3].

Для условия баритового месторождения на основании данныхотрещиноватости массива и полученныхпрочностных характеристик горных пород в образце (см. табл. 1) были определены значения коэффициента $а$ для основных типов горных пород, слагающих прибортовой массив, которые приведены в табл. 2.

Для определения размеров элементарных блоков использовались результаты экспериментальных работ, выполненных на карьерах Казахстана, в работе «Механика скальных массивов и устойчивость карьерных откосов» [4]. В работе [4] методами математической статистики и корреляционного анализа была произведена обработка замеров элементов структурных блоков в зависимости от глубины залегания пород. Обобщающие результаты экспериментальных работ по бортам карьеров Казахстана по определению изменения размеров структурных блоков в зависимости от глубины залегания в недрах приведены на puc. 3, из которого следует, что размер структурных блоков с увеличением глубины разработки увеличивается.

Средние размеры структурных блоков $\ell$, отдельных разностей в массиве для условий баритового месторождения, были приняты на основании данных по классифика-

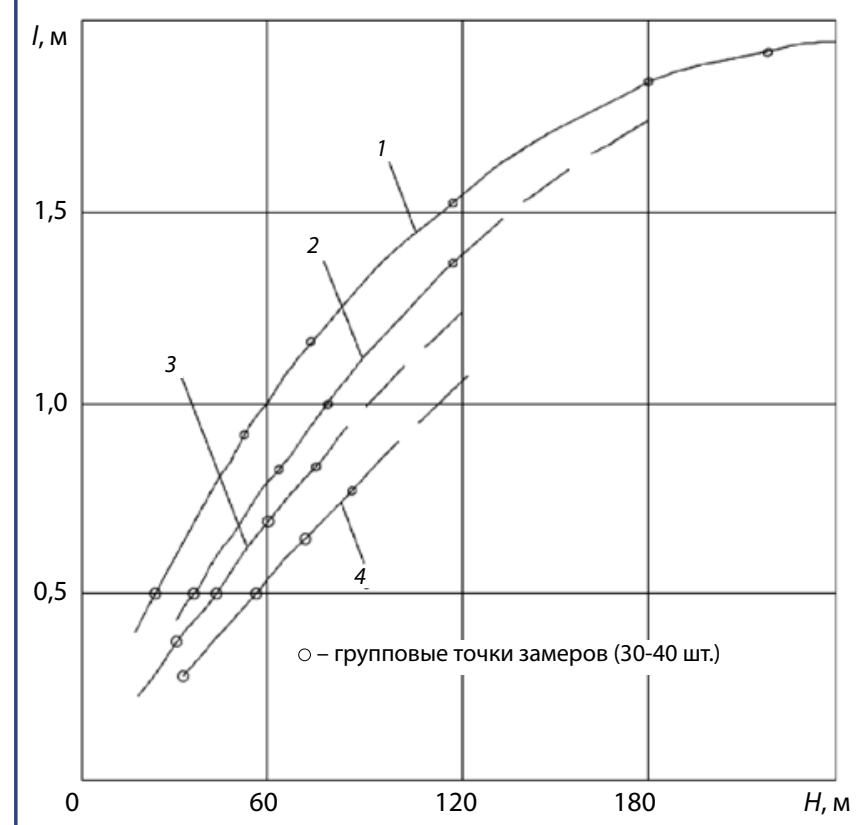

Рис. 3. Графики изменения средних размеров структурных блоков от глубины залегания пород на карьерах:

1 - «Карагайлинский»; 2 - «Саякский»; 3 - «Топарский»;

4 - «Алексеевский» [4, c. 51]

Fig. 3. Charts of change in the average size of structural blocks from the depth of occurrence of rocks in open-pits:

1 - "Karagaylinsky"; 2 - "Sayaksky"; 3 - «Toparsky»;

$4-$ - Alekseevsky» [4, P. 51]

ции скальных пород по степени трещиноватости и содержанию крупных кусков (табл. 3).

Результаты вычисления коэффициента структурного ослабления $\lambda_{0}$ для условий исследуемого баритового месторождения сведены в табл. 4.

Таблица 3

Размера структурных блоков по глубине залегания

\begin{tabular}{|c|c|}
\hline $\begin{array}{c}\text { Глубина залегания } \\
\text { горных пород } \boldsymbol{H , ~} \mathbf{M}\end{array}$ & $\begin{array}{c}\text { Средние размеры } \\
\text { структурных блоков } \ell, \mathbf{~ M}\end{array}$ \\
\hline $50-75$ & 0,3 \\
\hline $75-100$ & 0,5 \\
\hline $100-125$ & 0,7 \\
\hline $125-150$ & 1,1 \\
\hline
\end{tabular}


Таблича 4

Обоснование коэффициента структурного ослабления $\lambda$

\begin{tabular}{|c|c|c|c|c|}
\hline Типы пород & $\begin{array}{c}\text { Глубина } \\
\text { залегания } \\
\text { пород H, м }\end{array}$ & $\begin{array}{c}\text { Средний размер } \\
\text { элементарных } \\
\text { блоков } \ell, \text { м }\end{array}$ & $\begin{array}{c}\text { Величина } \\
\text { коэффициента a }\end{array}$ & $\begin{array}{l}\text { Коэффициент } \\
\text { структурного } \\
\text { ослабления } \lambda_{0}\end{array}$ \\
\hline Песчаники трещиноватые выветрелые & 75 & 0,3 & 3 & 0,057 \\
\hline $\begin{array}{l}\text { Известняки темно-серые, до розовато-серых, } \\
\text { иногда слоистые }\end{array}$ & 160 & 1,1 & 3 & 0,044 \\
\hline $\begin{array}{l}\text { Переслаивание песчаника с алевролитами } \\
\text { и углисто-кремнистыми }\end{array}$ & 125 & 0,7 & 3 & 0,039 \\
\hline Песчаники баритизированные и окварцованные & $70-150$ & 0,7 & 4 & 0,040 \\
\hline
\end{tabular}

Таблица 5

\section{Расчетные значения сцепления и угла внутреннего трения основных типов} пород месторождения $\kappa_{\text {расч. }}$ и $\rho_{\text {расч. }}$

\begin{tabular}{|c|c|c|c|c|c|}
\hline Тип породы & $\begin{array}{c}\text { Сцепление } \\
\text { в образце, } \\
\text { кПа }\end{array}$ & $\begin{array}{l}\text { Коэффициент } \\
\text { структурного } \\
\text { ослабления, } \lambda_{0}\end{array}$ & $\begin{array}{c}\text { Сцепление } \\
\text { в массиве, кПа }\end{array}$ & $\begin{array}{c}\text { Сцепление } \\
\text { расчетное, кПа, } \\
\text { при } n_{3}=1,3\end{array}$ & $\begin{array}{l}\text { Угол внутреннего } \\
\text { трения, } p\end{array}$ \\
\hline Песчаники трещиноватые выветрелые & 8000 & 0,057 & 456 & 350 & 33 \\
\hline $\begin{array}{l}\text { Известняки темно-серые, до розовато- } \\
\text { серых, иногда слоистые }\end{array}$ & 8700 & 0,044 & 383 & 294 & 31 \\
\hline $\begin{array}{l}\text { Переслаивание песчаника } \\
\text { с алевролитами и углисто-кремнистыми }\end{array}$ & 12100 & 0,039 & 472 & 363 & 25 \\
\hline $\begin{array}{l}\text { Песчаники баритизированные } \\
\text { и окварцованные }\end{array}$ & 16100 & 0,040 & 644 & 495 & 30 \\
\hline
\end{tabular}

Необходимо отметить, что при оценке устойчивости откосов уступов [5] размеры структурных блоков имеют второстепенное значение, более существенным и определяющим фактором являются протяженность и взаимная направленность трещин, состояние их поверхностей, вид заполнителя и ориентирование поверхностей ослабления относительно простирания откосов уступов и бортов карьера.

Сцепление горных пород в массиве определяется с использованием коэффициента структурного ослабления по формуле:

$$
\kappa_{\mathrm{M}}=\kappa_{\text {обр }} \lambda_{0} \text {. }
$$

В табл. 5 представлена величина сцепления и угла внутреннего трения основных типов пород определенных по методике ВНИМИ на основании построенных паспортов прочности горных пород и коэффициента структурного ослабления.

Для получения расчетных прочностных характеристик согласно исследованиям ВНИМИ [1, 3], необходимых для оценки устойчивости откосов уступов и бортов карьера, в ранее полученные $\kappa_{\text {м }}$ и $\varphi_{\text {м }}$ значения в зависимости от свойств пород, структурных особенностей месторождения и срока службы бортов карьера вводится коэффициент запаса $n_{3}=1,3$.

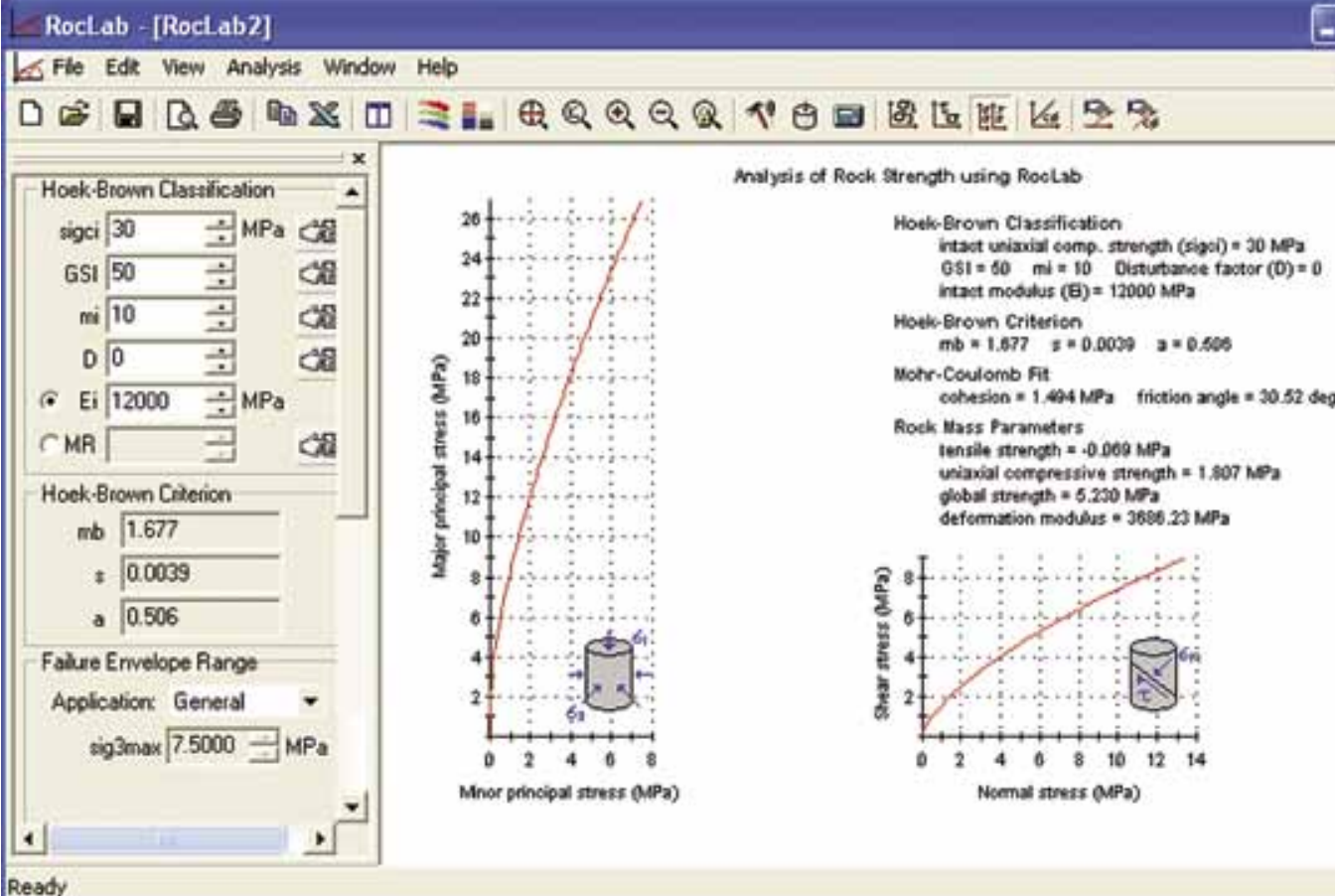

Puc. 4. Окно программы «RocLab» Fig. 4. RocLab program window 
Прочностные характеристики горных пород массива баритового карьера, определенные с использованием программного комплекса «RocLab»

\begin{tabular}{|c|c|c|c|c|c|c|}
\hline Тип пород & $\begin{array}{c}\text { Предел } \\
\text { прочности } \\
\text { на растяжение, } \\
\text { МПа }\end{array}$ & $\begin{array}{c}\sigma_{\mathrm{es}} \\
\mathbf{M} \Pi \mathbf{a}\end{array}$ & $\begin{array}{c}\text { Прочность } \\
\text { на сжатие, } \\
\text { МПа }\end{array}$ & $\begin{array}{c}\text { Геологический } \\
\text { индекс } \\
\text { прочности-GSI }\end{array}$ & $\begin{array}{l}\text { Расчетные } \\
\text { значения } \\
\text { сцепления к, } \\
\text { кПа }\end{array}$ & $\begin{array}{l}\text { Расчетные } \\
\text { значения } \\
\text { угла трения, } \\
\text { градус }\end{array}$ \\
\hline $\begin{array}{l}\text { Песчаники от средне- и мелкозер- } \\
\text { нистых до алевротистых, активно } \\
\text { выветрелые }\end{array}$ & $-0,003$ & 18 & 0,041 & 30 & 135 & 11 \\
\hline $\begin{array}{l}\text { Песчаники трещиноватые } \\
\text { выветрелые }\end{array}$ & $-0,006$ & 45 & 0,168 & 30 & 334 & 22 \\
\hline $\begin{array}{l}\text { Песчаники баритизированные } \\
\text { и окварцованные }\end{array}$ & $-0,008$ & 80 & 0,299 & 35 & 472 & 28 \\
\hline $\begin{array}{l}\text { Известняки темно-серые, до } \\
\text { розовато-серых, иногда слоистые }\end{array}$ & $-0,005$ & 50 & 0,113 & 30 & 277 & 18 \\
\hline $\begin{array}{l}\text { Переслаивание песчаника с алевро- } \\
\text { литами и углисто-кремнистыми }\end{array}$ & $-0,007$ & 50 & 0,187 & 35 & 349 & 22 \\
\hline Аральские глины & $-0,005$ & 2 & 0,033 & 25 & 79 & 8,43 \\
\hline Гематитовые руды & $-0,005$ & 100 & 0,226 & 30 & 507 & 27 \\
\hline
\end{tabular}

Таблица 7

Сравнение значений прочностных характеристик горных пород, определенных двумя методами

\begin{tabular}{|c|c|c|c|c|c|}
\hline \multirow[b]{2}{*}{ Типы пород } & \multicolumn{3}{|c|}{ Метод ВНИМИ } & \multicolumn{2}{|c|}{$\begin{array}{c}\text { Программный комплекс } \\
\text { «Rocklab» }\end{array}$} \\
\hline & $\begin{array}{l}\text { Коэффициент } \\
\text { структурного } \\
\text { ослабления } \lambda_{0}\end{array}$ & $\begin{array}{c}\text { Сцепление } \\
\text { расчетное, кПа, } \\
\text { при } n_{3}=1,3\end{array}$ & $\begin{array}{c}\text { Угол } \\
\text { внутреннего } \\
\text { трения, градус }\end{array}$ & $\begin{array}{c}\text { Сцепление, } \\
\text { кПа }\end{array}$ & $\begin{array}{c}\text { Угол } \\
\text { внутреннего } \\
\text { трения, градус }\end{array}$ \\
\hline Песчаники трещиноватые выветрелые & 0,057 & 350 & 24 & 334 & 22 \\
\hline $\begin{array}{l}\text { Известняки темно-серые, до розовато- } \\
\text { серых, иногда слоистые }\end{array}$ & 0,044 & 294 & 20 & 277 & 18 \\
\hline $\begin{array}{l}\text { Переслаивание песчаника } \\
\text { с алевролитами и углисто-кремнистыми }\end{array}$ & 0,039 & 363 & 21 & 349 & 22 \\
\hline $\begin{array}{l}\text { Песчаники баритизированные } \\
\text { и окварцованные }\end{array}$ & 0,040 & 495 & 30 & 472 & 28 \\
\hline
\end{tabular}

$$
\kappa_{\text {расч. }}=\frac{\kappa_{\mathrm{M}}}{n_{3}} ; \quad \rho_{\text {рачс. }}=\operatorname{arctg} *\left(\frac{\operatorname{tg} \rho_{\mathrm{M}}}{n_{3}}\right) .
$$

Вычисленные значения $\kappa_{\text {расч. }}$ и $\rho_{\text {расч. }}$ представлены в табл. 5.

Для надежного обоснования расчетных прочностных свойств горных пород в массиве карьера был использован программный комплекс «RocLab».

Программа «RocLab» [6] обеспечивает простую и понятную реализацию критерия разрушения Hoek-Brown'a, позволяя пользователям легко получать надежные оценки свойств массива горных пород и прямо на экране (в интерактивном режиме) видеть изменения огибающих разрушения (кривых прочности) при изменении параметров (рис. 4).

На основании выполненных построений огибающих разрушения основных типов пород, слагающих прибортовые массивы, определены расчетные прочностные характеристики (сцепления и угла внутреннего трения) горных пород в массиве, которые приведены в табл. 6.

Для оценки принятых расчетных значений прочностных характеристик горных пород выполнено сравнение результатов двух способов их определения: по методике ВНИМИ и с использованием компьютерной программы Rocklab. Результаты определения расчетных значений прочностных характеристик горных пород двумя способами приведены в табл. 7.
Анализ проведенных исследований показал хорошую сходимость результатов определения значений прочностных характеристик горных пород, которая лежит в пределах 3-5\%, что подтверждает правильность принятых решений.

\section{Список литературы}

1. Методические указания по определению углов наклона бортов, откосов уступов и отвалов строящихся и эксплуатируемых карьеров. Л.: ВНИМИ, 1972. 165 с.

2. Фисенко Г.Л. Устойчивость бортов карьеров и отвалов. М.: Недра, 1965. 378 с.

3. Методические указания по наблюдениям за деформациями бортов, откосов уступов и отвалов на карьерах и разработке мероприятий по обеспечению их устойчивости. Согласованы приказом Комитета по государственному контролю за чрезвычайными ситуациями и промышленной безопасностью Республики Казахстан от 22 сентября 2008 г. № 39.

4. Попов И.И., Окатов Р.П., Низаметдинов Ф.К. Механика скальных массивов и устойчивость карьерных откосов. Алма-Ата, 1986. 256 с.

5. Попов И.И., Окатов Р.П. Борьба с оползнями на карьерах. М.: Недра, 1980. 239 с.

6. Hoek, Evert, (2006), A Brief History of the Hoek-Brown Failure Criterion, unpublished document. 
UDC 539.3/.4:622.023.23 @ O.G. Besimbayeva, E.N. Khmyrova, S.P. Olenyuk, E.A. Oleynikova, O.V. Starostina, 2018

ISSN 0041-5790 (Print) • ISSN 2412-8333 (Online) • Ugol' - Russian Coal Journal, 2018, № 4, pp. 54-59

Title

VALIDATION OF DESIGN STRENGTH CHARACTERISTICS OF BARITE FIELD ROCKS

DOI: http://dx.doi.org/10.18796/0041-5790-2018-4-54-59

Authors

Besimbayeva O.G. ${ }^{1}$, Khmyrova E.N. ${ }^{1}$, Olenyuk S.P. ${ }^{1}$, Oleynikova E.A. ${ }^{1}$, Starostina O.V. ${ }^{1}$

${ }^{1}$ Karaganda State Technical University (KSTU), Karaganda, 100027, Republic of Kazakhstan

\section{Authors' Information}

Besimbayeva O.G., PhD (Engineering), Associate Professor of Department

"Mine Surveying and Geodesy", e-mail: bog250456@mail.ru

Khmyrova E.N., PhD (Engineering), Head of Department

"Mine Surveying and Geodesy", e-mail: hmyrovae@mail.ru

Olenyuk S.P., PhD (Engineering), Senior Lecturer of Department

"Mine Surveying and Geodesy", e-mail: savml@mail.ru

Oleynikova E.A., Master of Engineering, Senior Lecturer of Department

"Mine Surveying and Geodesy", e-mail: panasenkoelena@mail.ru

Starostina O.V., PhD (Engineering), Associate Professor of Department

"Mine Surveying and Geodesy", e-mail: o.starostina@kstu.kz

\section{Abstract}

The paper considers issues of validation of design values of strength characteristics of the barite field rocks. In order to solve this applied research task, rock strength passports were built according to the classical scheme, which reflect the physical and mechanical properties of rocks in the sample then one determined the structural rock loosening coefficient $\lambda 0$, which takes account of the effects of massif broken condition, structural block sizes, moisture content of rocks and other factors, and which allowed to proceed to the strength characteristics of rocks in the massif. In order to assess the design values of strength characteristics of rocks, one performed a comparison of the results of their determination using the VNIMI method and the Rocklab computer program. Analysis of the conducted studies showed a good within-run precision of determining values of strength characteristics of rocks, which lies within the limits of 3 to $5 \%$, which confirms the correctness of the decisions taken.

Figures:

Fig. 1. Sompound curve chart

Fig. 2. Strength certificate
Fig. 3. Charts of change in the average size of structural blocks from the depth of occurrence of rocks in open-pits: 1 - "Karagaylinsky"; 2 - "Sayaksky"; 3 - «Toparsky»; 4 - «Alekseevsky» [4, P. 51]

Fig. 4. RocLab program window

\section{Keywords}

Rock strength, Simple compression and tension of rocks, Rock strength passport, Structural rock loosening coefficient, Bond and angle of internal rock friction.

\section{References}

1. Metodicheskie ukazaniya po opredeleniyu uglov naklona bortov, otkosov ustupov i otvalov stroyashchikhsya i ekspluatiruemykh kar'erov [Methodical instructions for determining angles of inclination of the sides, slopes of ledges and dumps of the open-pits being built and operated]. Leningrad, VNIM Publ.,1972, 165 p.

2. Fisenko G.L. Ustoychivost' bortov kar'erov i otvalov [Stability of open-pits and dump sides]. Moscow, Nedra Publ., 1965, 378 p.

3. Metodicheskie ukazaniya po nablyudeniyam za deformatsiyami bortov, otkosov ustupov i otvalov na kar'erakh i razrabotke meropriyatiy po obespecheniyu $i k h$ ustoychivosti [Methodical instructions for observations of deformations of sides, slopes of ledges and dumps in open-pits and for development of measures for ensuring their stability]. Agreed by the order of the Committee for State Control over Emergencies and Industrial Safety of the Republic of Kazakhstan dated September 22, 2008, No. 39.

4. Popov I.I., Okatov R.P. \& Nizametdinov F.K. Mekhanika skal'nykh massivov i ustoychivost' kar'ernykh otkosov [Mechanics of rock massifs and stability of open-pit slopes]. Alma-Aty, 1986, 256 p.

5. Popov I.I. \& Okatov R.P. Bor'ba s opolznyami na kar'erakh [Open-pit slide control]. Moscow, Nedra Publ., 1980, 239 p.

6. Hoek, Evert (2006), A Brief History of the Hoek-Brown Failure Criterion, unpublished document.

Пресс-служба АО ХК «СДС-Уголь» информирует

\section{Инженеры ООО «СИГД» стали победителями Всероссийского конкурса «Новая идея»}

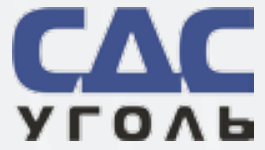

\begin{abstract}
Специалисты 000 "Сибирский Институт Горного Дела» (входит в состав АО ХК “СДС-Уголь») стали победителями Всероссийского конкурса «Новая идея» на лучшую научно-техническую разработку среди предприятий и организаций ТЭК в номинации "Лучшая инновачионная идея» в секции «Экология, охрана окружающей среды и рациональное использование природных ресурсов».
\end{abstract}

Конкурс «Новая идея» направлен на раскрытие и стимулирование научно-технического потенциала молодых специалистов топливно-энергетического комплекса России и проводится под эгидой Министерства энергетики Российской Федерации, при поддержке общественных и профессиональных организаций.

Всего в 2017 г. на конкурс подано более 250 заявок по 17 тематическим секциям из 100 отраслевых организаций.
Представленные конкурсантами работы посвящены актуальным проблемам развития топливно-энергетического комплекса России. Экспертами выступают специалисты ведущих отраслевых компаний и научно-исследовательских организаций России.

Специалисты ООО «СИГД» представили конкурсной комиссии «Лучшую инновационную идею» по проблеме обеззараживания воды и пути ее решения, разработав обеззараживающий комплекс для повышения качества очищенных сточных вод. В своей работе инженеры предложили использование полимерных реагентов в качестве основных компонентов, доказав не только экономическую эффективность эксплуатации данного комплекса, но, главное - обосновав отсутствие риска возникновения и развития чрезвычайной ситуации.

Торжественное награждение победителей Всероссийского конкурса «Новая идея» планируется в апреле. 


\section{Повышение эффективности использования}

природных и техногенных ресурсов

при открытой угледобыче в рамках концепции «зеленой» горнодобывающей промышленности

DOI: http://dx.doi.org/10.18796/0041-5790-2018-4-60-63

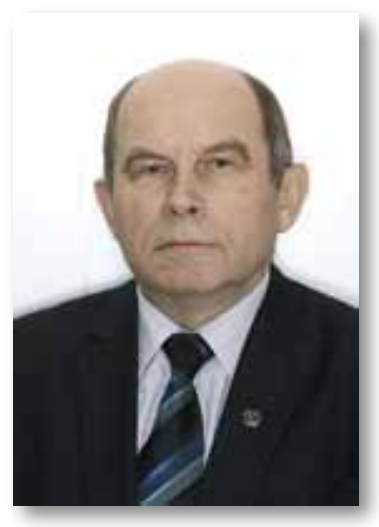

КОВАЛЕНКО

Владимир Сергеевич

Доктор техн. наук, профессор

Горного института НИТУ

«MИCuC»,

127247, г. Москва, Россия,

тел.: +7 (499) 230-25-52,

+7 (903) 121-62-72,

e-mail:Kovalenkov.s.48@gmail.ru
В статье приводится анализ использования природных ресурсов и техногенного воздействия предприятий угольной отрасли на окружающую среду, дается сравнение с наиболее масштабными нарушениями земельных ресурсов на самых крупных предприятиях США и Китая, описываются основные направления по повышению ресурсоэффективности и экологической безопасности предприятий, раскрываются основные принципы концепции «зеленой» промышленности, даются рекомендации по созданию землесберегающих и землевоспроизводящих технологий открытой добычи угля.

Ключевые слова: открытая угледобыча, ресурсопотребление, загрязнение окружающей среды, техногенные ресурсы, «зеленая» промышленность, ресурсоэффективность, экологическая безопасность, землесбережение и землевоспроизводство, экоинновационные технологии.

\section{ВВЕДЕНИЕ}

Угольная промышленность России - старейшая отрасль почти с трехсотлетней историей. Ресурсный потенциал России превышает 1,1 трлн т угля, из них только оцененных запасов - 235 млрд т [1]. Более половины (61\%) разведанных запасов углей пригодны для добычи высокоэффективным открытым способом. Из них более $88 \%$ сосредоточены в Сибирском федеральном округе (Кузнецкий и Канско-Ачинский бассейны) и $11 \%$ в Дальневосточном округе.

В 2017 г. достигнут рекордный в современной России объем добычи в 407,8 млн т. Половина (52,7\%) от этого объема приходится на Кузнецкий угольный бассейн. Программой развития угольной промышленности на период до 2030 г. предусматривается дальнейший рост объема добычи до 480 млн т.
По оценке ряда экспертов, планируемые темпы освоения угольных ресурсов и наращивания объемов добычи в среднем в 1,5-2\% в год не соответствуют ресурсному потенциалу страны. Вместе с тем многие специалисты сходятся во мнении, что сдерживающим фактором может являться в ближайшей перспективе экологическое состояние природной среды в ряде угледобывающих регионов страны, которое оценивается как сложное или даже критическое [2].

Так, например, для основного бассейна высококачественных углей - Кузбасса, в недрах которого сосредоточено порядка 600 млрд т, наступил, по мнению главы Кемеровской области Амана Тулеева, экономический предел роста угледобычи в регионе.

\section{ОСНОВНЫЕ НАПРАВЛЕНИЯ ПОВЫШЕНИЯ РЕСУРСОЭФФЕКТИВНОСТИ И ЭКОЛОГИЧЕСКОЙ БЕЗОПАСНОСТИ ОТКРЫТОЙ ДОБЫЧИ УГЛЯ}

В результате открытой угледобычи ежегодно большие площади земельных ресурсов страны отчуждаются горными работами, занимаются отвалами пустой породы, хвостохранилищами, золоотвалами и другими объектами. На больших территориях нарушаются естественные ландшафты, наносится непоправимый ущерб окружающей среде. Кроме того, нарушенные земли сами становятся очагами загрязнения атмосферы, воды и почв, прилегающих угодий, что свидетельствует о большом ущербе, наносимом угледобывающими предприятиями народному хозяйству и природной среде.

В последнее время отмечается интенсивный рост площади ежегодно нарушаемых земель. Так, за период с 2010 по 2014 г. темпы нарушения возрастали с 2136 до 4219 га, т.е. в 2 раза быстрее, чем ранее, и достигли средней землеемкости 11,8 га/млн т. Общая площадь нарушенных земель в угольной отрасли уже достигла порядка 100 тыс. га [3]. С учетом опережающего роста добычи угля открытым способом, усложнения горнотехнических условий разработки и особенностей, свойственных традиционно применяемым технологиям угледобычи, площадь нарушенных земельных ресурсов в дальнейшем будет только возрастать.

Увеличиваться будут и отходы горного производства, представленные в основном вскрышными породами. Объем образования за год отходов угледобывающих предприятий превышает 3 млрд т. Примерно половина (54\%) этого объема размещается во внешних отвалах, площадь которых подчас занимает более половины земельного отвода предприятия. Примерно такая ситуация с использованием земельных ресурсов наблюдается и в других горно- 
добывающих странах. Увеличение объемов добычи разнообразных полезных ископаемых в мире при сохранении традиционных технологий разработки позволяет специалистам прогнозировать дальнейшее ухудшение природной среды. В качестве примера можно привести данные угольных отраслей США и Китая, где достигнуты максимальные объемы угледобычи, а площади нарушенных земель в разы отличаются от российских показателей.

Так, в США наиболее масштабные нарушения земельных ресурсов характерны при освоении крупнейшего в мире (запасы 1600 млрд т до глубины 900 м) Аппалачского угольного бассейна, где примерно одна пятая часть (19,5\%) площади поверхности бассейна, или около 700 тыс. га, была нарушена горными работами [4].

Рекордные объемы добычи и нарушений природной среды характерны для угольной промышленности Китая. Ежегодно добывается порядка трех млрд т. В прошлые годы рекордные темпы роста угледобычи достигали 175 млн т в год. Причем практически вся добыча (97\%) ведется подземным способом в основном без закладки выработанного пространства шахт. В работе [5] отмечается, что в результате просадки дневной поверхности были уничтожены леса на площади 1060 тыс. га, пастбища - на 263 тыс. га, повреждены тысячи зданий, нарушена инфраструктура 25 городов и много чего другого. Все это вызвало серьезные загрязнения окружающей среды и экологическую деградацию природных экосистем, что является ключевой проблемой для устойчивого развития горнодобывающей промышленности страны. В этих условиях все большее внимание специалистов привлекает новая концепция, так называемая концепция «зеленой» горнодобывающей промышленности. Стратегическая задача этой концепции - повернуть горное производство, что называется, лицом к природе. Сегодня уже невозможно игнорировать такие явления, как сокращение биоразнообразия и разрушение естественных экосистем на суше и в воде, чрезмерное потребление и нерациональное использование природных ресурсов, загрязнение окружающей среды, изменение климата и многие другие отрицательные проявления не только в природе, но и в обществе.

«Зеленая» промышленность - это стратегия, которая развивает и дополняет принятый генеральный природоохранный курс ООН [6]. Экономический рост в рамках прежней модели скоро станет невозможен даже в развитых странах: земная экология не в силах удовлетворить растущие аппетиты потребителей, констатирует в «Зеленой революции» немецкий эколог и публицист Ральф Фюкс, бывший глава Фонда Белля. Россия не является исключением, она также нуждается в проведении современной промышленной политики, модернизации экономики и увеличении ее экологической эффективности. Поскольку многие страны мира переходят на «зеленые» технологии, потребность в разработке и реализации экоинновационных технологий открытой угледобычи должна повышаться. Россия, начав переход к «зеленой» промышленности, запустит важный механизм трансформации экономики страны, так называемый «принцип декаплинга», при котором потребности удовлетворяются без существенного увеличения давления на природу. Для этого требуется как продуманная государственная экологическая политика, так и опережающие инициативы со стороны регионов, угледобывающих компаний и предприятий.
На начальном этапе реализации данной стратегии важно правильно определить цели и расставить приоритеты. Безусловно, цели могут быть разными, но вектор должен быть общим, а именно, он определен в концепции как достижение ресурсоэффективности и создание экологически безопасного производства. При этом не может быть в мире единства в реализации этого направления по причине больших различий между горно-геологическими и горнотехническими условиями разработки, способами добычи, состоянием экономики стран и многими другими факторами. Так в США в качестве конечной цели ставится уже не добыча полезного ископаемого, а восстановление исходной природной экосистемы в процессе или после окончания работ. Однако вполне очевидно, что восстановление экосистемы до первоначального состояния не может быть достигнуто по многим причинам. В настоящее время имеются проекты восстановления лишь отдельных элементов экосистем, основанные на новых принципах, например на ландшафтной стратегии и «естественных» технологиях в экологическом восстановлении нарушенных земель [5]. В качестве примера можно привести проект Lionkol, который для Лионкольского угольного района в США реализовал на площади 320 акров методы геоморфологической рекультивации шахтных полей [7]. В качестве основной цели этого проекта являлось создание устойчивого рекультивированного ландшафта, который бы вписывался в окружающую местность и обеспечивал долгосрочную эрозионную стабильность вновь созданной поверхности.

Аналогичные проекты были разработаны в 1980-е годы в МГГУ для условий рекультивации внешних отвалов, отсыпанных на холмистой, достаточно пересеченной местности в южном районе Кузбасса. Имеются многочисленные примеры целенаправленного воздействия на земную поверхность для перевода ее в более ценные формы с позиций хозяйственного использования, эстетики и рекреации, что характеризует потенциальные возможности открытых горных работ [8].

Для условий месторождений России, когда основные запасы высококачественных углей сосредоточены в пластах крутого залегания, а не в горизонтальных или слабонаклонных, как в США и Китае, требуются другие решения в реализации концепции «зеленой» промышленности. Так, одним из направлений решения проблемы ресурсоэффективности и экологизации открытой добычи угля является, по мнению автора статьи, преобразование в структуре потребления природных ресурсов за счет вовлечения в производственный процесс создаваемых в процессе разработки техногенных ресурсов и в первую очередь пространственного техногенного ресурса - выработанного пространства карьера взамен земельного ресурса.

Данный техногенный ресурс может быть использован для различных целей: размещения вскрышных пород, создания техногенного месторождения или водоемов различного назначения, для строительства и других целей. По этой причине его относят к многофункциональному геотехнологическому ресурсу. Как любому ресурсу ему свойственны признаки экономической, экологической и социальной полезности. Причем полезность тех или иных потребительских свойств определяется прежде всего состоянием, направленностью и сроком его использования. 
Выделяют потенциальный и реальный ресурсы выработанного пространства [9]. Потенциальным ресурсом является карьерная выемка в земной коре, образуемая в результате перемещения горной массы за пределы границ карьера. Реальным ресурсом является часть или весь объем потенциального ресурса, пригодный для использования в конкретном направлении, например для складирования вскрышных пород или попутно добываемого полезного ископаемого при формировании техногенного месторождения.

Идея использовать техногенный ресурс выработанного пространства для размещения внутренних отвалов вскрышных пород при разработке любых типов залежей, в том числе крутозалегающих, зародилась еще в период становления открытых горных работ. Впервые она была высказана известным ученым и педагогом, одним из основоположников теории открытых горных работ профессором Е.Ф. Шешко [10]. Эту идею он реализовал в своем предложении по технологии разработки синклинальных складок Кузбасса. Это послужило началом создания нового направления в горной науке, которое оформилось под общим названием «землесберегающие и землевоспроизводящие технологии открытых горных работ».

В рамках этого направления, которое активно развивалось в МГИ - МГГУ, были созданы многие способы и технологии разработки крутых и наклонных залежей. В основе новых решений было заложено, как правило, изменение порядка развития горных работ в целях перевода потенциального ресурса выработанного пространства в реальный. Аналогичные исследования велись во многих других институтах России, Украины, Казахстана.

В настоящее время в современных экономических и экологическихусловияхповысился практический интерес ктехнологиям, позволяющим складировать породы вскрыши в выработанном пространстве карьера. Так, на некоторых разрезах страны реализуют в основном блочный и этапный порядки отработки карьерных полей, возможность применения которых появилась по истечении нескольких десятков лет, когда определенные участки карьеров достигли проектных контуров. Между тем доказано, что наибольшая эффективность и экологическая безопасность разработки достигаются в случае вовлечения техногенного ресурса выработанного пространства карьера в производственный процесс не периодически, как при блочном порядке, а непрерывно на всех этапах эксплуатации месторождения. Это один из главных технологических принципов порядка развития горных работ при отработке горизонтальных месторождений, где достигнуты наиболее высокие показатели ресурсосбережения. Данный принцип должен быть распространен и на технологии разработки крутозалегающих месторождений угля, эффективность которого доказана многими исследованиями и подтверждена практическим опытом [11].

Эти технологии, назовем их землесберегающие и землевоспроизводящие технологии открытых горных работ, обладают рядом технологических возможностей и отличительными признаками от традиционных технологий и наиболее полно отвечают требованиям ресурсосбережения и охраны окружающей среды. Отличительные особенности этих технологий и требования, предъявляемые к ним, заключаются в следующем:

- вовлечение (желательно ускоренное) в производственный процесс техногенного ресурса выработанно- го пространства карьера взамен земельного ресурса для размещения вскрышных пород за счет перевода его из пассивного в активное состояние, то есть когда весь или часть потенциального ресурса переводится в разряд реального ресурса;

- технологическая возможность целенаправленного управления воспроизводством техногенного ресурса выработанного пространства в процессе отработки запасов полезного ископаемого согласно потребностям горного производства (для размещения вскрышных пород, невостребованных попутных полезных ископаемых и других целей);

- землеемкость открытых горных работ должна быть существенно снижена по сравнению с традиционными технологиями, а режимы отчуждения земельных ресурсов и восстановления нарушенных земель должны отвечать требованиям рационального землепользования;

- формирование внутренних и внешних отвалов вскрышных пород должно отвечать нормативным требованиям технической и биологической рекультивации нарушенных земель, предъявляемым к принятому в проекте направлению их освоения;

- объем запасов угля, вовлекаемых в открытую разработку, и экономическая эффективность их добычи должны быть не меньше, чем при традиционных технологиях угледобычи;

- открытая разработка должна соответствовать требованиям рационального недропользования, создавать необходимые условия, способствующие достижению высокой эффективности, в том числе последующей разработки месторождения подземным способом;

- открытые горные работы должны оказывать минимальное техногенное воздействие на состояние и качество подземных и поверхностных вод и минимизировать выбросы загрязняющих веществ в атмосферу.

Этот перечень может быть расширен с учетом конкретных условий с акцентированием на наиболее важных проблемах недропользования и охраны окружающей среды в целях достижения не только высокой эффективности разработки месторождений, но и поддержания состояния экосистемы на нормативном уровне.

Все вышеперечисленные требования направлены на создание угледобывающих предприятий экоинновационного уровня, обладающих высоким производственноэкономическим потенциалом и отвечающих современным требованиям рационального недропользования и охраны окружающей среды. Они вполне вписываются в концепцию «зеленой» горнодобывающей промышленности.

\section{ЗАКЛЮЧЕНИЕ}

Совершенствование открытого способа угледобычи должно быть направлено в первую очередь на повышение эффективности использования природных и техногенных ресурсов и на снижение техногенной нагрузки на окружающую природную среду, что соответствовало бы требованиям концепции «зеленой» промышленности, которая в последнее время реализуется в передовых горнодобывающих странах мира. Для этого имеется от науки ряд эффективных инновационных технологий, направленных на решение данной проблемы, которые ждут своего внедрения в производство. 


\section{Список литературы}

1. Глинина О.И. Угольная промышленность в России: 295 лет истории и новые возможности // Уголь. 2017. № 10. C. 4-10. URL: http://www.ugolinfo.ru/Free/102017.pdf (дата обращения: 15.03.2018).

2. Оценка экологической емкости природной среды в угледобывающих регионахсучетом перспективы развития угольной промышленности / Ю.В. Шувалов, М.В. Паршина, Е.П. Зуев и др. // Горный информационно-аналитический бюллетень. 2009. № 3. С. 314-321.

3. Харионовский А.А., Васева В.Н, Симанова Е.И. Охрана окружающей среды в угольной промышленности России // Уголь. 2016. № 4. С. 79-82. URL: http://www.ugolinfo.ru/ Free/042016.pdf (дата обращения: 15.03.2018).

4. Reconstructing disturbance history for an intensively mined region by time-series analysis of Landsat imagery / Jing Li, Carl E. Zipper, Patricia F. Donovan, Randolph H. Wynne, Adam J. Oliphant. Environmental Monitoring and Assessment, IX. 2015.

5. Hao Bing-yuan and Kang Li-xun. Taiyuan University of Technology, Taiyuan, Shanxi 030024, China Mine Land Reclamation and Eco-Reconstruction in Shanxi Province I: Mine Land Reclamation Model Hindawi Publishing Corporation //
Scientific World Journal. 2014. Vol. Article ID 483862. 9 p.

6. Захарова Т.В. О поиске модели перехода к «зеленой» экономике в России // Вестник Томского государственного университета. 2016. № 4.

7. Harold J. Hutson and Robert W. Thoman Advancements in geomorphic mine reclamation design approach, Wyoming abandoned mine land, lioncol coal mining district, Sweetwater county // Wyoming Journal American Society of Mining and Reclamation. 2017. Vol. 6. N 2.

8. Ильин С.А., Коваленко В.С., Пастихин Д.В. Преодоление изначальных недостатков открытого способа разработки: опыт и результаты // Горный журнал. 2012. № 4. С. 25-30.

9. Трубецкой К.Н., Пешков А.А., Мацко Н.А. Определение области применения способов разработки крутопадающих залежей с использованием заранее сформированного выработанного пространства карьера // Горный журнал. 1994. № 1. С. 51-59.

10. Шешко Е.Ф. Основы проектирования угольных карьеров. М.: Углетехиздат, 1950. 335 с.

11. Коваленко В.С., Артемьев В.Б., Опанасенко П.И. Землесберегающие и землевоспроизводящие технологии на угольных разрезах. М.: Из-во «Горное дело» ООО «Киммерийский центр», 2013. 440 с.

MINERALS RESOURCES

UDC 622.271:622.85 @ V.S. Kovalenko, 2018

ISSN 0041-5790 (Print) • ISSN 2412-8333 (Online) • Ugol' - Russian Coal Journal, 2018, № 4, pp. 60-63

\section{Title}

INCREASE IN EFFICIENCY OF NATURAL AND MAN-MADE RESOURCES USE IN OPEN COAL MINING WITHIN THE FRAMEWORK OF THE CONCEPT OF “GREEN" MINING INDUSTRY

DOI: http://dx.doi.org/10.18796/0041-5790-2018-4-60-63

\section{Author}

Kovalenko V.S

${ }^{1}$ National University of Science and Technology "MISIS" (NUST "MISIS"), Moscow, 119049, Russian Federation

\section{Authors' Information}

Kovalenko V.S., Doctor of Engineering Sciences, Professor Mining Institute, tel.: +7 (499) 230-25-52, +7 (903) 121-62-72, e-mail:Kovalenkov.s.48@gmail.ru

\section{Abstract}

The paper analyses the natural resources use and man-made impact of coal industry facilities on the environment, it gives their comparison with the most large-scale disturbances of land resources in the largest facilities in the United States and China, it describes the main directions for improving resource efficiency and environmental safety of facilities, it explains the basic principles of the concept of green Industry and gives recommendations for creation of earth-saving and land-renewing technologies for surface mining.

\section{Keywords}

Surface mining, Resource consumption, Environmental pollution, Man-made resources, "Green" industry, Resource efficiency, Environmental safety, Landsaving and land rehabilitation, Eco-innovation technologies.

\section{References}

1. Glinina O.I. Ugol'naya promyshlennost'v Rossii: 295 let istorii i novye vozmozhnosti [The coal industry in Russia: 295 year history and new opportunities]. Ugol'- Russian Coal Journal, 2017, No. 10, pp. 4-11. Available at: http://www. ugolinfo.ru/Free/102017.pdf (accessed 15.03.2018).

2. Shuvalov Yu.V. Parshina M.V.Zuev E.P. et al. Otsenka ekologicheskoy emkosti prirodnoy sredy $v$ ugledobyvayushchikh regionakh s uchetom perspektivy razvitiya ugol'noy promyshlennosti [Evaluation of environmental capacity of the natural environment in coal mining regions taking account of the coal industry growth prospects]. Gornyy Informatsionno-Analiticheskiy Byulleten' - Mining Information and Analytical Bulletin, 2009, No. 3. pp. 314-321. 3. Kharionovskiy A.A., Vaseva V.N. \& Simanova E.I. Okhrana okruzhayushchey sredy $v$ ugol'noy promyshlennosti Rossii [Environment protection in the Russian coal industry]. Ugol'- Russian Coal Journal, 2016, No. 4, pp. 79-82.
Available at: http://www.ugolinfo.ru/Free/042016.pdf (accessed 15.03.2018). 4. Jing Li, Carl E. Zipper, Patricia F. Donovan, Randolph H. Wynne \& Adam J. Oliphant Reconstructing disturbance history for an intensively mined region by time-series analysis of Landsat imagery. Environmental Monitoring and Assessment, IX. 2015.

5. Hao Bing-yuan and Kang Li-xun Taiyuan University of Technology, Taiyuan, Shanxi 030024, China Mine Land Reclamation and Eco-Reconstruction in Shanxi Province I: Mine Land Reclamation Model Hindawi Publishing Corporation. Scientific World Journal, 2014, Vol. Article ID 483862, 9 p.

6. Zakharova T.V., O poiske modeli perekhoda k «zelenoy» ekonomike v Rossii [On searching model of transition to green economy in Russia]. Vestnik Tomskogo gosudarstvennogo universiteta - Bulletin of the Tomsk state university, 2016, No. 4.

7. Harold J. Hutson \& Robert W. Thoman Advancements in geomorphic mine reclamation design approach, Wyoming abandoned mine land, lioncol coal mining district, Sweetwater county. Wyoming Journal American Society of Mining and Reclamation, 2017, Vol. 6, No. 2.

8. Ilyin S.A., Kovalenko V.S. \& Pastikhin D.V. Preodolenie iznachal'nykh nedostatkov otkrytogo sposoba razrabotki: opyt i rezul'taty [Overcoming the initial shortcomings of the opencast mining method: experience and results]. Gornyy Zhurnal - Mining Journal, 2012, No. 4, pp. 25-30.

9.Trubetskoy K.N., Peshkov A.A.\&Matsko N.A. Opredelenie oblasti primeneniya sposobov razrabotki krutopadayushchikh zalezhey s ispol'zovaniem zaranee sformirovannogo vyrabotannogo prostranstva kar'era [Determining scope of use of the methods of mining steeply sloping deposits using the pre-formed working quarry space]. Gornyy Zhurnal-Mining Journal, 1994, No. 1, pp. 51-59. 10. Sheshko E.F. Osnovy proektirovaniya ugol'nykh kar'erov [Coal quarry design basis]. Moscow, Ugletekhizdat Publ. 1950, 335 p.

11. Kovalenko V.S., Artemiev V.B. \& Opanasenko P.I. Zemlesberegayushchie i zemlevosproizvodyashchie tekhnologii na ugol'nykh razrezakh [Land-saving and land rehabilitation, technologies in coal open-pit mines]. Moscow, "Gornoye delo" Publ., "Kimmeriysky Tsentr" LLC, 2013, 440 p. 


\section{Для сотрудников разреза «Черниговец» и шахты «Южная» построят дом в г. Березовском}

В г. Березовском забита первая свая нового жилого дома для работников разреза «Черниговец» и иахты "Южная» (входят в состав АО ХК «СДС-Уголь»). Церемонию начала строительства нового социального объекта открыл 14 марта 2018 г. заместитель губернатора Кемеровской области по строительству Александр Николаевич Шнитко.

Строительство 5-этажного жилого дома в Березовском городском округе осуществляется холдинговой компанией «Сибирский Деловой Союз» в рамках реализации программ льготного ипотечного кредитования и развития социальной инфраструктуры для работников градообразующих предприятий. Жилищный проект инициирован губернатором Кемеровской области Аманом Гумировичем Тулеевым.

По словам президента ХК «СДС» Михаила Юрьевича Федяева, данный проект уникален коротким сроком исполнения (дом планируется сдать к концу августа) и теми условиями, на которых квартиры в нем могут приобрести горняки и шахтеры.

Льготы на данное жилье предоставляются заслуженным и перспективным работникам, молодым специалистам, многодетным семьям. Изначально первый взнос в полном объеме берет на себя предприятие. При условии достойного инициативного труда и значимого вклада в развитие производства на протяжении следующих трех лет данная сумма с работника взиматься не будет. Процентная ставка по ипотеке составит 8,9\% на 10 лет, половину которой за работника также оплачивает предприятие. Таким образом, для сотрудников угольных предприятий процентная ставка составит 4,45\%.

Жилой 70-квартирный дом будет выполнен из железобетонных конструкций серии панельного домостроения европейского стандарта, отвечающего всем требованиям энергосбережения. Все работы от проектирования до изготовления материалов и возведения дома выполня-

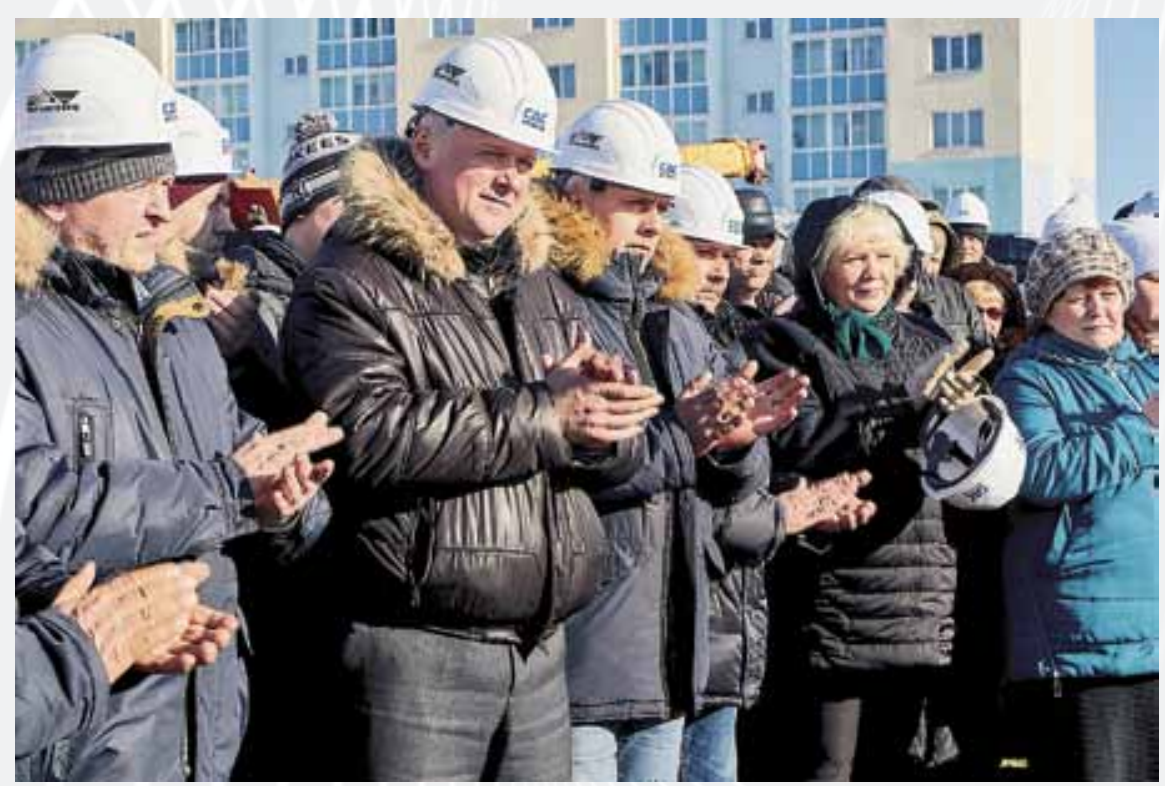

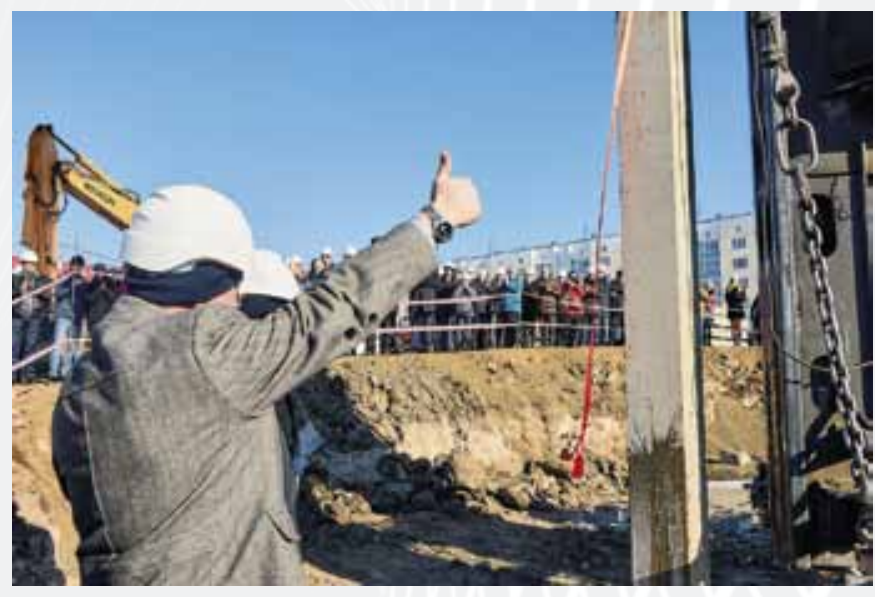

ют предприятия строительной отрасли «Сибирского Делового Союза».

Создание комфортных, качественных условий проживания людей, привлечение и закрепление ценных сотрудников на предприятиях в настоящее время являются приоритетным направлением в развитии угольной отрасли «Сибирского Делового Союза». В настоящее время холдинг уже реализует льготные жилищные программы для сотрудников кемеровского «Азота». Также в ближайшее время планируется начало строительства жилья для работников шахты «Листвяжная» (АО ХК «СДС-Уголь») в поселке Грамотеино Беловского городского округа.

Наша справка.

Холдинговая компания «Сибирский Деловой Союз» является крупнейшим многоотраслевым холдингом России. В активы ХК «СДС» входят: крупнейшие угледобывающие предприятия Кузбасса; энергетическая компания; предприятия химического машиностроения и вагоностроения; интегрированные с собственными животноводческими высокотехнологичными комплексами предприятия пищевой промышленности (производство молочной продукции); компании строительногокомплекса, а также крупнейший медиахолдинг Кемеровской области, представляющий популярные радиостаниии и мероприятия российского масштаба.

АО ХК «СДС-Уголь» основано в 2006 г. и является отраслевым холдингом $A O$ ХК «Сибирский Деловой Союз». Сегодня в составе угольного холдинга: четыре разреза, две шахты, четыре обогатительные фабрики и ряд сервисныхпредприятий, расположенных на территории Кемеровской области с общей численностью сотрудников около 9 тыс. человек. За 12 лет своего существования компания вышла на третье место в России по объемам добычи угля и входит в тройку крупнейших российских экспортеров угольной продукции. 


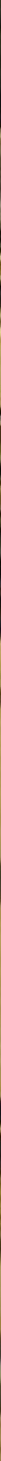

\section{Эфрфективные решения для горнодобывающей промышленности}

Широкий спектр оборудования Trio ${ }^{\circledR}$ предлагает стандартные и индивидуальные решения для предприятий горнодобывающей промышленности - от дробилок и грохотов, передвижных дробильно-сортировочных установок, до рудоподготовительных комплексов

горно-обогатительных фабрик. По всем проектам компания Weir Minerals предлагает полный спектр услуг - от разработки технологического процесса и расчета оборудования, до квалисрицированного сервисного обслуживания и поставки запасных и быстроизнашиваемых деталей и узлов.

Получите консультацию наших инженеров, позвонив по телефону + 74957750852

Защищено авторским правом (c) 2015 r., Weir Minerals Australia Ltd. Bce права защищены. TRIO и логотип TRIO являются торговыми марками и/или зарегистрированными торговыми марками компаний Trio Engineering Products, Inc. и Trio China Ltd:; WEIR и логотип WEIR являются торговыми марками и/или зарегистрированными торговыми марками компании Weir Engineering Services Ltd.

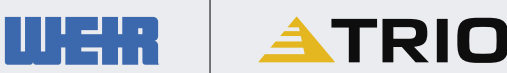

Minerals

ООО «Веир Минералз РФЗ»

Россия, 127083, г. Москва

Ул. 8 Марта, д. 1, стр. 12

sales.ru@weirminerals.com www.global.weir 


\section{Больше угля - больше денег}

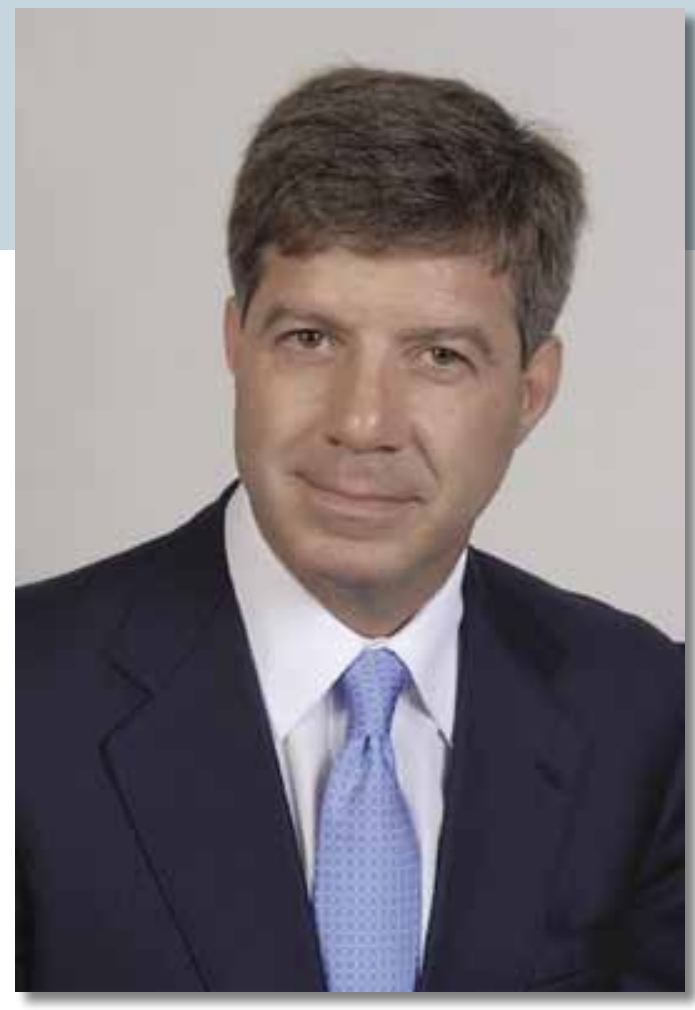

Дэвид ДЖОВАНИС

Генеральный директор компании

«Somerset International Russia»,

143026, Сколково, Россия,

тел.: +7 (495) 994-46-67,

e-mail:david.geovanis@somersetcoal.ru
Угольная промышленность России, несмотря на непростые геополитические условия, находится на позитивном этапе своего развития: растут объемы добычи и переработки угля, обновляются производственные мощности, увеличиваются налоговые отчисления отрасли в бюджет. В настоящее время все угольные компании стараются существенно повысить свою производительность и рентабельность путем применения новейших мировых технологий. Компания «Somerset International Russia» - лидер в области технологии извлечения и обезвоживания мелкого угля, Готова Содействовать в этом. В Статье представлены разработки и инновационные решения в области углеобогащения. Ключевые слова: обогатительные фабрики, улавливание, обезвоживание, технологии углеобогащения, осадительная центрифуга, ультрамелкий уголь, система Sub325 $5^{\circledR}$.

\section{О разработках и инновационных решениях в области угольной индустрии рассказывает генеральный директор компании "Somerset International Russia» Дэвид Джованис.}

Дэвид, мы знаем, что компания «Somerset International Russia" является лидером в области извлечения мелкого угля и занимается уникальными инновационными решениями в области угольной индустрии. Что Вы предлагаете на нашем рынке?

Мы предоставляем нашим клиентам услугу, которая помогает улучшить работу их предприятий сразу по двум направлениям: первое - повышение общей производительности углеобогатительных фабрик; второе - улавливание и обезвоживание мелкоугольных частиц размером 44 микрона (325 меш), извлечение которых невозможно при использовании традиционных технологий углеобогащения. Мы разработали и запатентовали революционную технологию, основанную на работе запатентованной суперскоростной осадительной центрифуги и вспомогательного оборудования, которые позволяют нам улавливать ультрамелкий уголь.

Что Вы имеете в виду, когда говорите «Мы предоставляем услугу»?

Уникальна не только наша технология, но и сам подход к тому, каким образом мы можем помочь нашим клиентам оптимизировать их фабрики. Наша задача проста - сделать так, чтобы клиенты получали больше угля и зарабатывали больше денег. Следует с самого начала прояснить, что мы не являемся продавцами оборудования. Более того, мы много раз были вынуждены отклонить предложения о покупке нашего оборудования. Мы работаем совместно с обогатительными фабриками и помогаем им увеличить выход и стать более эффективными. С установкой нашей системы Sub325 ${ }^{\circledR}$ фабрики становятся более производительными, потому что извлекают больше мелкого угля. На большинстве обогатительных фабрик России мелкий уголь либо теряется в фугате, либо попадает в рециркуляцию рабочего процесса фабрики. Наша система Sub325 ${ }^{\circledR}$ позволяет улавливать ценный уголь, который оказывается потерянным, и избежать возвращения частиц мелкого угля в циркуляцию, тем самым снимая нагрузку с оборудования и делая процесс обогащения значительно более эффективным.

Повторюсь: мы не продаем систему Sub325 ${ }^{\circledR}$. Вместо этого мы устанавливаем, оперируем и обслуживаем систему для наших клиентов. Привлеченные нами технические специалисты обеспечивают максимальное использование операционного потенциала фабрики после внедрения системы Sub325 ${ }^{\circledR}$.

Если Вы не продаете оборудование, каким образом Вы зарабатываете деньги?

Наш подход таков - мы зарабатываем деньги, только если клиент зарабатывает деньги в результате работы нашей системы. Мы заключаем с клиентом договор о предоставлении услуги, по которому мы разделяем доход, полученный в результате извлечения до- 
полнительных тонн угля, которые были бы отправлены в хвостохранилища. Клиентов устраивает подобная договоренность, потому что они получают значительные дополнительные доходы от нового угля, который они ранее теряли. Поскольку мы разделяем доход от извлеченного угля, у нас есть огромный стимул для постоянного мониторинга производительности завода, чтобы обеспечить его максимальную эффективность.

Вам не кажется, что это радикальный подход к работе с клиентами?

Честно говоря, на всех встречах, которые у нас были с клиентами, первоначальная реакция - «мы не собираемся делиться с вами своими доходами». Но на всех фабриках, где были установлены системы Sub325 ${ }^{\circledR}$ (США, Канада, Австралия), клиенты согласились с тем, что наш подход к разделу доходов от дополнительного угля является беспроигрышным для обеих сторон. Клиенты довольны тем, что мы инвестируем в саму систему, а также ее установку и обслуживание. Как только они видят, сколько дополнительных денег мы можем заработать для них каждый год без каких-либо инвестиций от них, они с готовностью принимают наш подход. Для одного из наших клиентов - крупнейшего международного угледобывающего конгломерата - мы установили систему на нескольких принадлежащих ему фабриках.

Еще очень важным является тот факт, что, поскольку мы вкладываем в установку наших систем миллионы долларов собственных средств, мы делаем это только в том случае, если абсолютно уверены, что можем принести значительные дополнительные доходы - иначе, зачем брать на себя риск. Принимая весь риск и затраты на себя, мы избавляем наших клиентов и от рисков, и от затрат.

Какого рода "улучшений» в работе фабрик вы смогли достичь?

На сегодняшний день на 15 фабриках, где были установлены наши системы, они производят в среднем 15-20 т угля в час дополнительно. Предположим, завод работает 5000 часов в год, тогда получаем за год около 100 тыс. т. По цене 100 дол. США за 1 т это составляет 10 млн дол. США дополнительной годовой выручки!

Где именно в схеме фабрики обычно устанавливается ваше оборудование?

Технология центрифугирования широко используется в углеобогащении с конца 1980-х годов для извлечения и обезвоживания мелкого угля. Осадительно-фильтрующие центрифуги (ОФЦ) эффективны и экономичны и в значительной степени заменили собой вакуумные фильтры. Тем не менее, в сравнении с вакуумными фильтрами
ОФЦ, как правило, не извлекают весь ультрамелкий уголь и существенное количество обогащенного мелкого угля уходит через щели в сите (обычно он подвергается рециркуляции, но лишь частично извлекается) или выводится в фугат. Наша система улавливает около 95\% мелкого угля, который на сегодняшний день не способны извлечь осадительно-фильтрующие центрифуги (см. рисунок). На рисунке приведена схема, где наша центрифуга расположена под традиционной ОФЦ.

Не могли бы Вы рассказать больше о самой центриdyze?

Несмотря на то, что технология центрифугирования существует в угольной промышленности с 1970-х гг., до недавнего времени она не была проработана настолько, чтобы быть экономически обоснованной.

Получаемый в результате уголь был слишком влажным, поэтому технология не находила признания в области обогащения угля. Компания «Somerset Coal International» усовершенствовала технологию, разработала машину Sub325 и сделала возможным получение угля размером не более

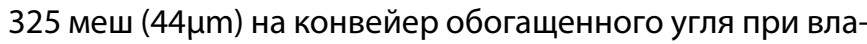
ге не более $20 \%$.

Была изменена внутренняя геометрия декантерной центрифуги, что позволило извлекать ультрамелкие частицы угля с низким содержанием влаги. Благодаря изменениям в управлении процессором были достигнуты оптимальные гравитация и крутящий момент, в результате чего стало происходить идеальное разделение частиц угля и воды. Увеличенный диапазон переменных параметров позво-

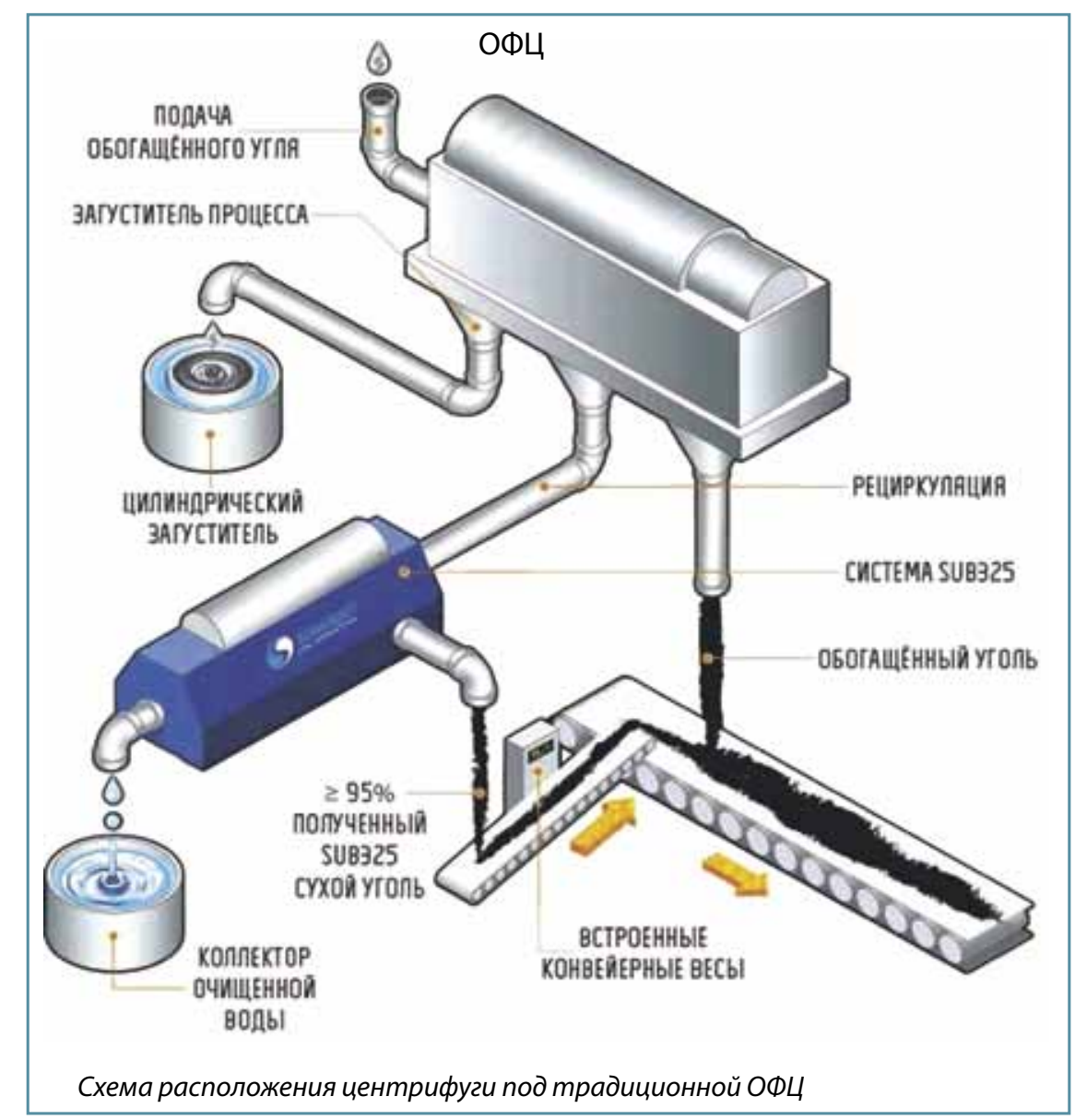


лил оптимизировать вращательный дифференциал между ковшом и шнеком центрифуги.

Эти три ключевые улучшения позволили системе Sub325 ${ }^{\circledR}$ существенно снизить влагу в конечном продукте.

Работа нашего оборудования основана на мощной технологии центрифугирования с использованием осадительной центрифуги, выделяющей чистый уголь из воды. Для постоянного наблюдения за вводом в систему необходимых операционных данных и внесением корректировок используется программируемый логистический контроллер. Скоростью управляет гидравлический привод, обеспечивающий максимально возможную центробежную силу, максимальные результаты и идеальное разделение воды и мелкого угля.

Где на сегодняшний день установлено ваше оборудование и есть ли у вас объекты в России?

Наши системы установлены более чем на 15 фабриках в США, Канаде и Австралии. Уже несколько потенциальных клиентов из России посетили некоторые из наших зарубежных объектов и были очень впечатлены тем, что они увидели. Ведь недаром говорят: «увидеть - значит, поверить».

В настоящее время мы находимся на продвинутой стадии коммерческих переговоров с несколькими ведущими российскими угольными компаниями, которые очень заинтересованы в нашем оборудовании. Мы были очень рады узнать, что в ведущих угольных компаниях России работают образованные высококлассные инженеры, живо интересующиеся использованием новейших технологий для повышения производительности своих предприятий. Этим компаниям также импонирует наш подход и наша бизнес-модель, согласно которой мы берем на себя все инвестиционные риски, а прибыль делим.

\section{С каким углем вы работаете?}

Мы работаем со всеми типами угля, включая энергетический, коксующийся и антрацит.

Вы давно работаете в угольном бизнесе и, конечно, знаете, как важны теоретические знания, практический опыт и специфика работы на международном уровне. Расскажите нам о своей управленческой команде, которая добилась столь значительных результатов и где находятся офисы вашей компании?

Нашу компанию возглавляет команда ведущих мировых профессионалов - экспертов углеобогащения с 25-летним и более стажем работы в отрасли. Эти люди проектировали, строили, перестраивали и управляли фабриками в России, США, Канаде, Австралии, Индии и Индонезии. Президент и главный инженер нашей компании хорошо знакомы с российской угледобывающей промышленностью, поскольку оба имеют опыт работы на руководящих должностях в компании «Северсталь Ресурс». В России мы собрали команду молодых талантливых технологов и инженеров с опытом в области обогащения угля.

Штаб-квартира нашей компании находится в районе угольного бассейна в штате Пенсильвания (США), где также располагается наша передовая исследовательская лаборатория. У нас также есть офисы в Нью-Йорке, Ванкувере и Дублине. Кроме того, много работаем в Австралии. В России наш штаб находится в Сколково, высокотехнологичном сообществе за пределами Москвы, где также есть и другие инновационные энергетические компании. Недавно мы открыли офис в Кемерове и планируем открыть еще один офис в Воркуте.

\section{COAL PREPARATION}

UDC 622.7:622.33 @ D. Geovanis, 2018

ISSN 0041-5790 (Print) • ISSN 2412-8333 (Online) •

Ugol' - Russian Coal Journal, 2018, № 4, pp. 66-68

Title

THE MORE COAL THE MORE MONEY

Author

David Geovanis ${ }^{1}$

1"Somerset International Russia" LLC, Skolkovo, 143026, Russian Federation

\section{Authors' Information}

David Geovanis, General Director, tel.: +7 (495) 994-46-67,

e-mail: david.geovanis@somersetcoal.ru

\section{Abstract}

The Russian coal industry, despite the hard geopolitical conditions, is in the positive stage of its growth: coal production and processing volumes are being increasing, production capacities are being updated, and the industry's tax deductions to the budget are also increasing. To date, all coal companies are trying to improve significantly their productivity and profitability by implementing the latest world technologies. Somerset International Russia company is a leader in the technology of slack coal extraction and dehydration, is ready to assist in this. The article presents developments and innovative solutions in the field of coal benefication.

Keywords

Benefication plants, Trapping, Dehydration, Coal benefication technologies, Settling centrifuge, Super slack coal, Sub325 system. (Сомерсет Интернэшнл Раша):

- 143026, Московская обл., Сколково, ул. Новая, д.100, офис 203 тел.: +7 (495) 994-46-67; +7 (985) 210-21-48

- Кемерово, пр-т Октябрьский, д.2Б, офис 801

тел.: +7 (905) 9945398 


\title{
Методы оценки обогатимости углей
}

\author{
DOI: http://dx.doi.org/10.18796/0041-5790-2018-4-69-74
}

Рассмотрены графические методы определения обогатимости: Анри, Бэрда, Майера. ГОСТ 10100-84 «Метод определения обогатимости», основанный на данных построения кривых Анри, не дает возможности определить, какой процесс разделения для данного угля наиболее выгодный. Поэтому рассмотрены альтернативные методы Бэрда и Майера.

Ключевые слова: гранулометрический состав, фракционный анализ, кривые обогатимости, кривые флотируемости, плотность разделения.

\section{ВВЕДЕНИЕ}

Методы оценки обогатимости углей до настоящего времени продолжают оставаться объектами исследований. Обогатимость углей - показатель характеризующий распределение золы в элементарных слоях угля различной плотности и важный показатель, при разработке проектов новых и реконструкции действующих обогатительных фабрик.

Для решения практических задач действующих и проектируемых фабрик для обогащения угля, выбора методов и режимов обогащения, технологических схем и оборудования, расчета ожидаемых результатов обогащения, формирования сырьевых баз, управления качеством в процессе обогащения необходима информация о гранулометрическом и фракционном составе и обогатимости углей.

Ситовый и фракцонный анализ сырьевой базы обогатительной фабрики определяется соответственно по ГОСТ 2093-82 «Топливо твердое. Ситовый метод определения гранулометрического состава» и ГОСТ 4790-93 (ISO 7936:1992) «Топливо твердое. Определение и представление показателей фракционного состава. Общие требования к аппаратуре и методике».

Отбор производится в соответствии с ГОСТ 10742-71 «Угли бурые, каменные, антрацит, горючие сланцы и угольные брикеты. Методы отбора и подготовки проб для лабораторных испытаний».

\section{ИССЛЕДОВАНИЯ ОБОГАТИМОСТИ УГЛЯ}

Следует отметить, что для действующих и проектируемых обогатительных фабрик отбор проб для производства ситового и фракционного анализов необходимо производить с учетом измельчения угля от шахты (разреза) до обогатительной фабрики.

Данные ситового и фракционного состава представляются не только в виде сводных таблиц, но и изображаются графически [1].

Обогатимость характеризует способность углей к разделению на составляющие компоненты по плотности: концентрат, промежуточный продукт и порода (отходы). Обогатимость в настоящее время определяется по ГОСТ 10100-84 «Угли каменные и антрацит. Метод определения обогатимости» [2].

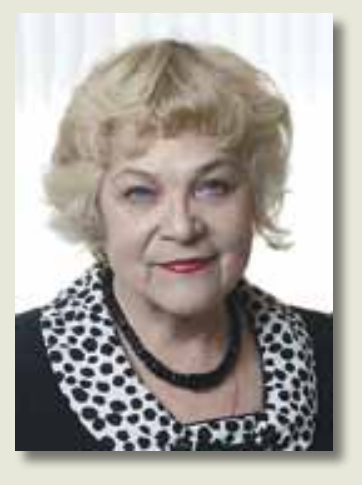

\author{
АНТИПЕНКО \\ Лина Александровна \\ Доктор техн. наук, профессор, \\ советник генерального \\ директора \\ ООО «Сибнииуглеобогащение», \\ 653000, г. Прокопьевск, Россия, \\ e-mail: AntipenkoLA@suek.ru
}

В основу исследований определения обогатимости угля приняты классические кривые Анри, которые не дают возможности непосредственно определить, какой процесс разделения для данного угля наивыгоднейший. Между тем при проектировании углеобогатительных фабрик важно знать не только распределение элементарных фракций и их суммарное значение, но и то, при каком режиме процесс разделения наиболее выгоден по выходу концентрата и промежуточного продукта.

По ГОСТ 10100-84 в зависимости от значений показателя обогатимости (Т) угли делят на четыре категории: легкая - 5\%, средняя - 5-10\%, трудная - 10-15\% и очень трудная - более $15 \%$.

Установлено, что оценка, основанная на выходе промежуточных фракций, не характеризует уголь как сырье для обогащения. Она не позволяет получать сырье определенного качества. Из исследований степени загрязнения концетрата при обогащении в отсадочных машинах, тяжелосредных сепараторах и гидроциклонах установлено, что она не определяется однозначно содержанием только промежуточных фракций в исходном сырье.

На использовании показателей выхода и зольности легких фракций основано большое количество методов оценки обогатимости углей $[3,4]$.

Известные методы сводятся к условно принятым отвлеченным шкалам или индексам, которые, по существу, не связаны с режимами работы обогатительного оборудования. Необходимо разработать метод, который бы указывал на оптимальный режим разделения угля тем или иным способом.

Кроме метода Анри распространение получили графические методы Бэрда, Фомина, Топоркова, Прейгерзона, Фоменко, Майера, Улицкого и др.

Одним из наиболее применимых для практического использования является метод Бэрда. Сущность метода заключается в том, что решающим фактором, определяющем обогатимость углей, является количество материала, которое содержится в известных пределах выше и ниже плотности разделения данного угля на составляющие компоненты. 


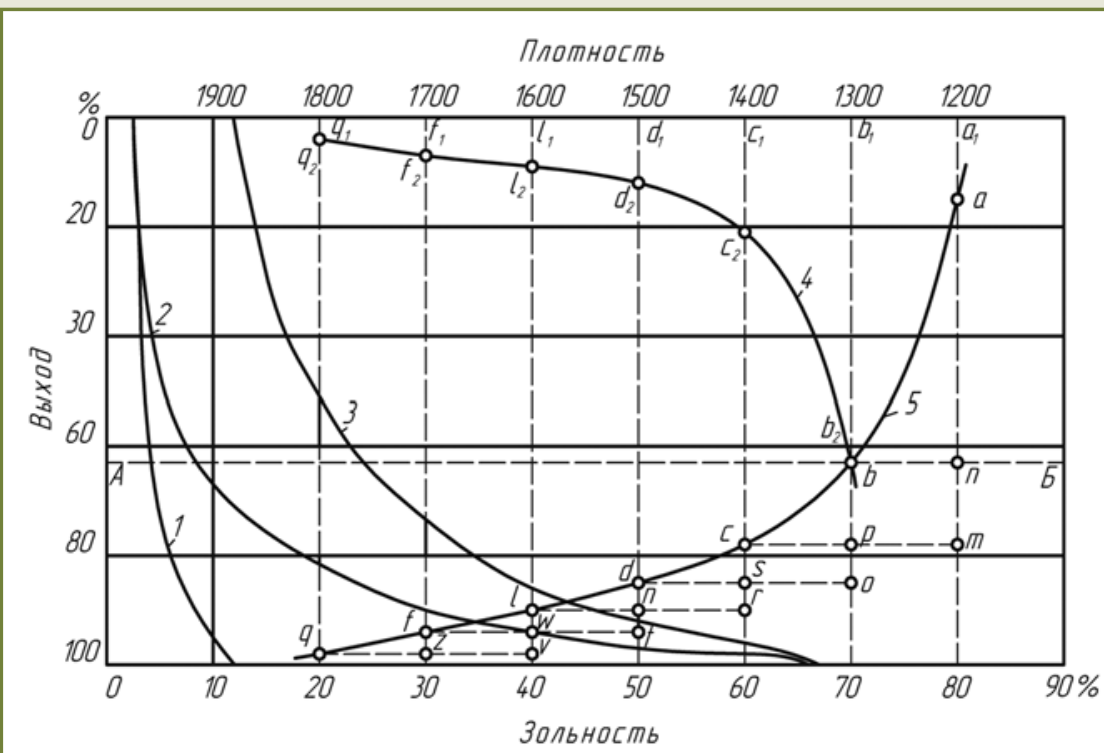

Рис. 1. Кривая Бэрда, построенная графическим путем: 1 - кривая средних зольностей концентрата $\beta ; 2$ - кривая элементарных зольностей $\lambda ; 3$ - кривая средних зольностей отходов $\theta ; 4$ - кривая Бэрда; 5 - кривая плотностей $\delta$

$\theta$ и плотностей $\delta$. Параллельно оси ординат проводится ряд вертикалей, соответствующих плотностям: 1200, 1300, 1400, 1500 и т.д. с интервалом в 100 кг/м³. Вертикали пересекают кривую плотностей $\delta$.

Если, например, точку с пересечения кривой плотности $\delta$ с вертикалью 1400 кг/м³ спроектировать на вертикаль 1200 в точке $m$, то отрезок $m$ - $a$ на вертикали 1200 кг/м³ (проекция кривой $c-b-a$ ) дает весовой процент частиц материала с плотностью 1200-1400 кг/м³. Отрезок $n-a$ (проекция кривой $b-a$ ) дает весовой процент частиц материала с плотностью 1300-1400 кг/м³. Подобным образом находятся все точки для построения кривой обогатимости Бэрда.

Об обогатимости угля по принятой плотности разделения судят по величине отрезков, отсекаемых на кривой \pm 100 кг/м³ вертикальной линией, проходящей через точку данной плотности.

Пределы отклонения от разделительной плотности приняты Бэрдом на основании экспериментальных данных \pm 100 кг/м³. Например, если разделительная плотность равна 1400 кг/м³ , то все сводится к определению материала, содержащегося в пределах 1300-1500 кг/м³. Если один уголь содержит этой фракции 5\%, а другой 15\%, то первый уголь будет обогащаться легче, чем второй. Порода плотностью более 2000 кг/м³ исключается из рассмотрения. Исключение чистой породы необходимо во избежание получения ошибочного представления о действительной обогатимости угля, так как наличие случайно попавшей породы кровли или почвы при добыче сказывается на величинах, характеризующих этот уголь. Наличие породы увеличивает зольность угля, а выход концентрата уменьшается. Между тем разделительная способность не уменьшается, так как порода легко отделяется. Однако количество фракции \pm 100 кг/Mㄹ плотности, окажется меньше, что может привести к ложному выводу о более легкой обогатимости угля.

Кривая отклонений \pm 100 кг/м³ может быть построена графическим путем. На диаграмме (рис.1) строятся кривые Анри: кривая зольности элементарных фракций $\lambda$, средней зольности концентрата $\beta$, средней зольности отходов
Чем больше отсекаемый отрезок, тем больше содержание близких по плотности зерен к разделительной плотности и тем труднее обогатимость этого угля.

Для построения кривых Бэрда вводится поправка на содержание чистой породы. Если в угле содержится 9\% материала плотностью более 2000 кг/м³ (антрацит), то остаток более легкого материала составит 91\%. Следовательно, поправочный коэффициент будет равен 100/91 = 1,1.

Bapuaнm 1. В табл. 1 приведен фракционный анализ угля, на основании которого построены кривые Анри и Берда графическим путем (рис. 2).

Кривую Бэрда можно построить аналитическим путем на основании фракционного анализа. На диаграмме (рис. 3) строятся кривые зольности обогащенного угля и плотностей. По кривой плотностей отсчитывается процентное содержание материала в пределах плотностей

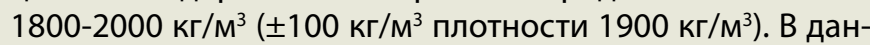
ном случае количество этого материала составляет 3,2\% от исходного. Количество материала с плотностью более 2000 кг/м³ составляет 9\%. Поправка на чистую породу составит 100/(100-9)=1,1. Следовательно, содержание материала фракции 1800-2000 кг/м³ будет не 3,2, а 3,52. Результаты подсчетов приведены в табл. 2.

Таблица 1

\section{Фракционный анализ угля}

\begin{tabular}{|c|c|c|c|c|c|c|}
\hline \multirow{3}{*}{ 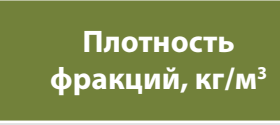 } & \multirow{3}{*}{$\gamma, \%$} & \multirow{3}{*}{$A d, \%$} & \multicolumn{4}{|c|}{ Суммарные фракции, \% } \\
\hline & & & \multicolumn{2}{|c|}{ Всплывшие } & \multicolumn{2}{|c|}{ Потонувшие } \\
\hline & & & $\gamma, \%$ & $A d, \%$ & $\gamma_{,} \%$ & $A d, \%$ \\
\hline Менее 1300 & 48,8 & 4,2 & 48,8 & 4,2 & 100,0 & 16,9 \\
\hline $1300-1400$ & 27,1 & 10,5 & 75,9 & 6,4 & 51,2 & 29,0 \\
\hline $1400-1500$ & 5,8 & 19,1 & 81,7 & 7,3 & 24,1 & 49,7 \\
\hline $1500-1600$ & 2,8 & 27,6 & 84,5 & 8,0 & 18,3 & 59,4 \\
\hline $1600-1700$ & 2,0 & 32,6 & 86,5 & 8,6 & 15,5 & 65,2 \\
\hline $1700-1800$ & 1,3 & 46,0 & 87,8 & 9,2 & 13,5 & 70,0 \\
\hline $1800-1900$ & 2,0 & 48,0 & 89,8 & 10,1 & 12,2 & 72,6 \\
\hline $1900-2000$ & 1,2 & 65,7 & 91,0 & 10,8 & 10,2 & 77,4 \\
\hline Более 2000 & 9,0 & 79,0 & 100,0 & 16,9 & 9,0 & 79,0 \\
\hline Итого: & 100,0 & 16,9 & - & - & - & - \\
\hline
\end{tabular}


Вариант 2. В табл. 3, 4 приведены данные для построения кривых Бэрда для каменного угля (плотность породы более 1800 кг/м³). На рис. 4 приведена кривая Бэрда, построенная графическим путем, а на рис. 5 аналитическим путем.

Аналогичные кривые могут быть выведены не только на основании материалов исследования в лабораторных условиях, но и также и на основе результатов и данных, получаемых при испытании угля на обогатительных машинах, работающих в производственных условиях.

Сравнивая полученные, таким образом, в производственных условиях показатели с лабораторными, можно вывести коэффициент эффективности данной машины в различных условиях ее работы, а именно:

$$
\eta=\frac{Q}{Q_{1}},
$$

где $Q$ - выход обогащенного угля на машине, \%; $Q_{1}$ - выход угля той же зольности согласно кривой, \%.

Бэрд предложил следующие показатели обогатимости углей (табл. 5).

Оценка обогатимости носит весьма условный характер, так как она не связана с режимом обогащения. Поэтому по такому разбиению нельзя подобрать наиболее эффективный метод обогащения и оборудования, тем более правильный режим обогащения.

Определять обогатимость только по наличию промежуточных фракций нецелесообразно, они, как известно, определяются характером кривой элементарных фракций.

Учитывая практический опыт обогащения в мировой практике предлагается с уточнением пригодности методов обогащения следующая градация обогатимости. В табл. 6 приведены для каждой степени трудности конкретные методы обогащения угля.

Для определения результатов обогащения совершенными и теоретически обоснованными являются методы по параметрам кривой разделения $E_{\rho m}$ и $I$. Эти параметры характеризуют работу обогатительной машины независимо от характеристики исходного угля. Они являются коэффициентами точности работы машины $[5,6]$.

Для расчета $E_{\rho m}$ и I можно применять один из трех методов: метод октилей, аналитический и графический. Наиболее точные результаты дает аналитический метод, который очень хорошо координируется с графическим методом Бэрда, так как фракционный состав исходного угля необходимо проверить по удельным весам

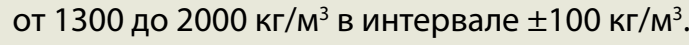

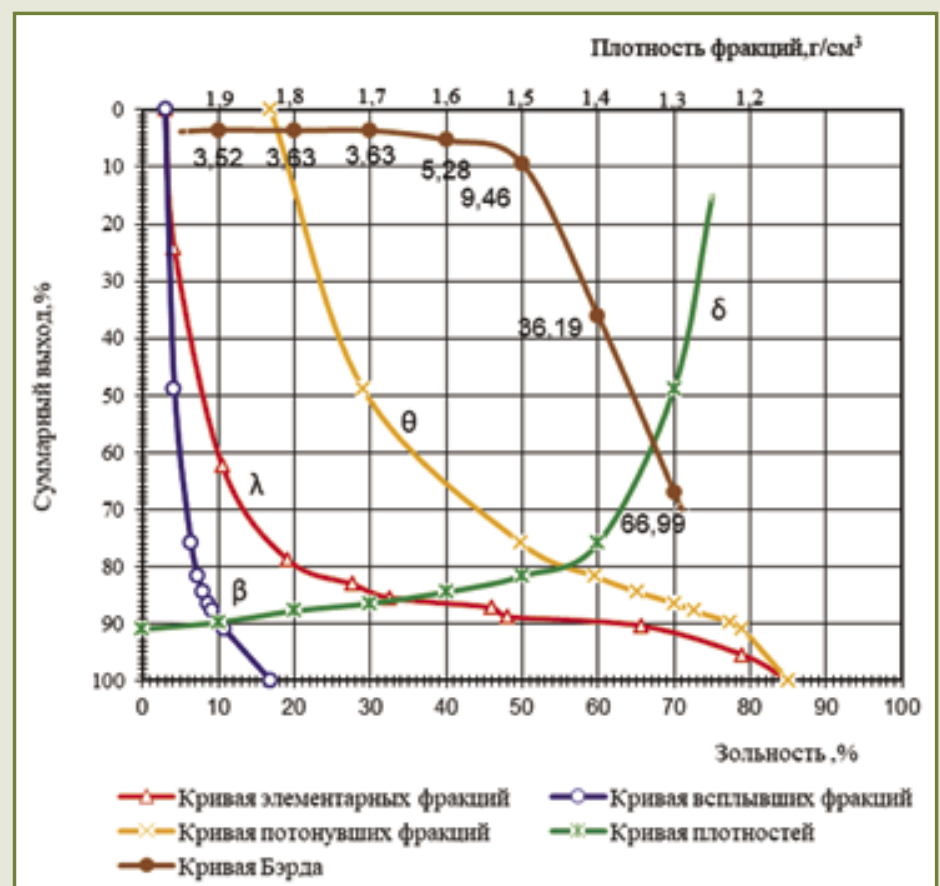

Pис. 2. Кривая Бэрда, построенная графическим путем (І вариант)

\section{Подсчитанные отклонения \pm 100 кг/m}

\begin{tabular}{|c|c|c|c|c|c|c|}
\hline \multirow{3}{*}{ 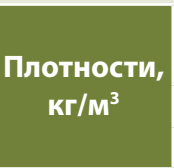 } & \multicolumn{4}{|c|}{ Отсчеты выходов по кривой Анри } & \multicolumn{2}{|c|}{$\begin{array}{c}\text { Величина отклонения } \pm 100 \text { кг/м } \\
\text { (\% весового выхода) }\end{array}$} \\
\hline & \multicolumn{2}{|c|}{ Для плотности + 100 кг/м³ } & \multicolumn{2}{|c|}{ Для плотности -100 кг/м³ } & Без поправки & С поправкой \\
\hline & Плотность, кг/м³ & Выход, \% & Плотность, $\mathrm{kr} / \mathrm{M}^{3}$ & Выход, \% & На материал тяжеле & ости $2000 \mathrm{kr} / \mathrm{m}^{3}$ \\
\hline 1900 & 2000 & 91,1 & 1800 & 87,8 & 3,2 & 3,52 \\
\hline 1800 & 1900 & 89,8 & 1700 & 86,5 & 3,3 & 3,63 \\
\hline 1700 & 1800 & 87,8 & 1600 & 84,5 & 3,3 & 3,63 \\
\hline 1600 & 1700 & 86,5 & 1500 & 81,7 & 4,8 & 5,28 \\
\hline 1500 & 1600 & 84,5 & 1400 & 75,9 & 8,6 & 9,46 \\
\hline 1400 & 1500 & 81,7 & 1300 & 48,8 & 32,9 & 36,19 \\
\hline 1300 & 1400 & 75,9 & 1200 & 15,0 & 60,9 & 66,99 \\
\hline
\end{tabular}


Фракционный анализ угля

\begin{tabular}{|c|c|c|c|c|c|c|}
\hline \multirow{3}{*}{ 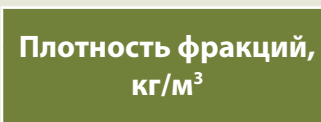 } & \multirow{3}{*}{$\gamma, \%$} & \multirow{3}{*}{$A d, \%$} & \multicolumn{4}{|c|}{ Суммарные фракции, \% } \\
\hline & & & \multicolumn{2}{|c|}{ Всплывшие } & \multicolumn{2}{|c|}{ Потонувшие } \\
\hline & & & $\gamma, \%$ & $A d, \%$ & $\gamma, \%$ & $A d, \%$ \\
\hline Менее 1300 & 48,8 & 4,2 & 48,8 & 4,2 & 100 & 16,9 \\
\hline $1300-1400$ & 27,1 & 10,5 & 75,9 & 6,4 & 51,2 & 29,0 \\
\hline $1400-1500$ & 5,8 & 19,1 & 81,7 & 7,3 & 24,1 & 49,7 \\
\hline $1500-1600$ & 2,8 & 27,6 & 84,5 & 8,0 & 18,3 & 59,4 \\
\hline $1600-1700$ & 2,0 & 32,6 & 86,5 & 8,6 & 15,5 & 65,2 \\
\hline $1700-1800$ & 1,3 & 46,0 & 87,8 & 9,2 & 13,5 & 70,0 \\
\hline Более 1800 & 12,2 & 72,6 & 100 & 16,9 & 12,2 & 72,6 \\
\hline Итого: & 100 & 16,9 & - & - & - & - \\
\hline
\end{tabular}

Подсчитанные отклонения \pm 100 кг/m

Таблица 4

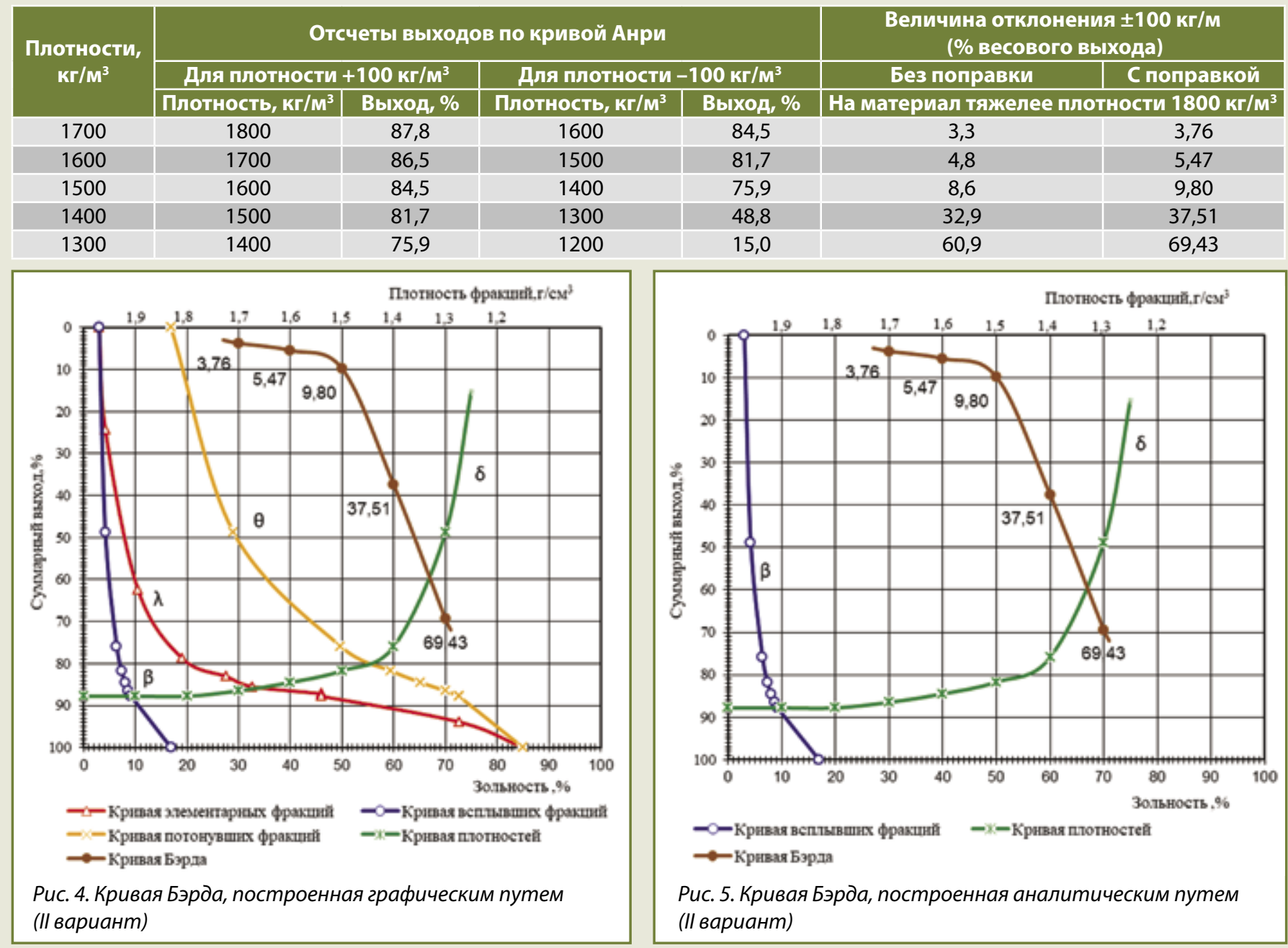

\section{Показатели обогатимости углей по Бэрду}

\begin{tabular}{|c|c|c|}
\hline $\begin{array}{l}\text { Показатель кривой } \\
\pm 100 \mathrm{kr} / \mathrm{M}^{3}\end{array}$ & Степень трудности & Пригодность методов обогащения \\
\hline $0-7 \%$ & Легкая & Применимы все методы. Высокая производительность машин. \\
\hline $7-10 \%$ & Средняя & $\begin{array}{l}\text { Применимы методы с высокой эффективностью. } \\
\text { Производительность машин хорошая }\end{array}$ \\
\hline $10-15 \%$ & Трудная & $\begin{array}{l}\text { Применимы методы с высокой эффективностью. } \\
\text { Производительность машин средняя. Требуется хороший контроль }\end{array}$ \\
\hline $15-20 \%$ & Очень трудная & $\begin{array}{l}\text { Применимы методы с высокой эффективностью. } \\
\text { Производительность машин низкая. Требуется хороший контроль }\end{array}$ \\
\hline $20-25 \%$ & Исключительно трудная & $\begin{array}{l}\text { Применимы методы с очень высокой эффективностью. } \\
\text { Производительность машин низкая. Требуется хороший контроль }\end{array}$ \\
\hline Более $25 \%$ & Почти непреодолимая & $\begin{array}{l}\text { Может быть осуществлено только на установках с исключительно высокой } \\
\text { эффективностью при чрезвычайно хорошем контроле и регулировке }\end{array}$ \\
\hline
\end{tabular}


Методы обогащения угля для каждой степени трудности

\begin{tabular}{|c|c|c|}
\hline $\begin{array}{c}\text { Показатель кривой } \\
\pm 100 \mathrm{kr} / \mathrm{M}^{3}\end{array}$ & Степень трудности & Пригодность методов обогащения \\
\hline $0-7 \%$ & Легкая & $\begin{array}{l}\text { Пневматический метод обогащения. Гравитационные методы: отсадка, } \\
\text { спиральные сепараторы, гидросайзеры. } E_{\text {рm }} ; I\end{array}$ \\
\hline $7-10 \%$ & Средняя & $\begin{array}{l}\text { Гравитационные методы: узкоклассифицированная отсадка, тяжелосредные } \\
\text { сепараторы и гидроциклоны. } E_{\text {рm }} ; I\end{array}$ \\
\hline $10-15 \%$ & Трудная & $\begin{array}{l}\text { Только тяжелосредное обогащение: двухстадийная сепарация. Возможно, } \\
\text { трехпродуктовые циклоны для мелкого угля }\end{array}$ \\
\hline $15-20 \%$ & Очень трудная & $\begin{array}{l}\text { Только тяжелосредное обогащение: сепараторы и гидроциклоны, двухстадий- } \\
\text { ная сепарация с переобогащением промпродуктовой фракции крупного зерна }\end{array}$ \\
\hline $20-25 \%$ & Исключительно трудная & $\begin{array}{l}\text { Противоточные гравитационные сепараторы, крутонаклонные сепараторы, } \\
\text { КНС для отделения породных фракций }\end{array}$ \\
\hline Более $25 \%$ & Почти непреодолимая & $\begin{array}{l}\text { Обогащение неприменимо. Возможно применение дробления крупных классов } \\
\text { для раскрытия сростков для последующего обогащения }\end{array}$ \\
\hline
\end{tabular}

Таблица 7

Данные для построения кривой Майера

\begin{tabular}{|c|c|c|c|c|c|}
\hline \multirow{2}{*}{$\begin{array}{c}\text { Продукт } \\
\text { флотации }\end{array}$} & \multirow[b]{2}{*}{$\begin{array}{c}\text { Выход } \\
P_{1} \%\end{array}$} & \multirow[b]{2}{*}{$\begin{array}{c}\text { Зольность } \\
d_{1}, \%\end{array}$} & \multirow{2}{*}{$\frac{P_{1} \cdot d}{100}$} & \multicolumn{2}{|c|}{ Координаты } \\
\hline & & & & $\sum \frac{P_{1} \cdot d}{100}$ & $\sum P$ \\
\hline K1 & 2,9 & 6,8 & 0,2 & 0,2 & 2,9 \\
\hline K2 & 8,4 & 6,8 & 0,6 & 0,8 & 11,3 \\
\hline K3 & 18,4 & 9,3 & 1,7 & 2,5 & 29,7 \\
\hline K4 & 13,2 & 8,3 & 1,1 & 3,6 & 42,9 \\
\hline K5 & 9,1 & 10,7 & 1,0 & 4,6 & 52,0 \\
\hline K6 & 14,0 & 11,4 & 1,6 & 6,2 & 66,0 \\
\hline K7 & 6,3 & 15,2 & 1,0 & 7,2 & 72,3 \\
\hline K8 & 8,3 & 18,5 & 1,5 & 8,7 & 80,6 \\
\hline K9 & 2,0 & 24,3 & 0,5 & 9,2 & 82,6 \\
\hline K10 & 2,9 & 31,5 & 1,0 & 10,2 & 85,5 \\
\hline K11 & 1,5 & 41,7 & 0,6 & 10,8 & 87,0 \\
\hline K12 & 1,2 & 53,9 & 0,6 & 11,4 & 88,2 \\
\hline K13 & 1,5 & 60,0 & 0,9 & 12,2 & 89,7 \\
\hline Итого: & 89,7 & 13,6 & 12,2 & 20,9 & 100,0 \\
\hline Отходы: & 10,3 & 84,8 & 8,7 & - & \\
\hline Всего: & 100,0 & 20,9 & 20,9 & - & \\
\hline
\end{tabular}

Кривые обогатимости Бэрда не отражают обогатимость мелких классов углей крупностью менее 0,5 мм, тем более что этот класс крупности на фабриках обогащается методом флотации, где в процессе участвуют флотационные реагенты. Известна кривая Майера - кривая флотируемости мелких частиц угля крупностью менее 0,5 мм. Кривая флотируемости построена по результатам опытов дробной флотации (табл. 7, рис. 6).

Опыт дробной флотации позволяет определить качество продуктов флотации и расходы реагентов. Кривая флотируемости Майера представляет собой векторное изложение результатов опыта дробной флотации или так называемой «идеальной» флотации.

Построение кривой производят на планшете специальной формы. На оси ординат откладываются значения выхода концентратов, на оси абсцисс - их зольность. Ордината планшета, как правило, принимается 25 см. С целью уменьше-

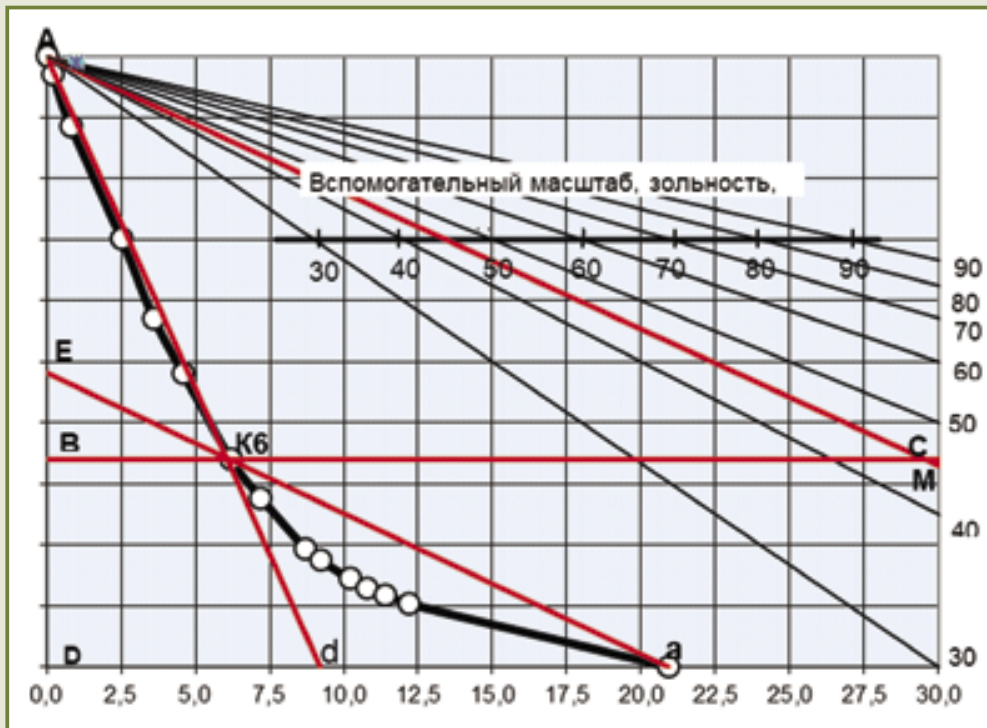

Рис. 6. Кривая обогатимости Майера

ния размеров и более удобного пользования значения более $30 \%$ отложены на вертикальной линии, проведенной из точки оси абсцисс параллельно оси ординат. Из точки $A$ (см. рис. 6) проводятся лучи отсчета со значением зольности свыше 30\%. Для более удобного нахождения зольности можно использовать вспомогательный масштаб. 
Пример определения выхода и зольности продуктов флотации приведен на рис. 6 для концентрата 6 (кб). Через точку кб проводится демаркационная линия $B-C$. Выход концентрата и породы отсекается на оси ординат $B-C$. Выход концентрата равен 66\%, породы - 34\%. Зольность концентрата определяемая путем прямого отсчета по оси зольностей от точки $d$, полученной проведением луча $A-d$ через точку к6, до начала координат, составляла 9,2\%.

Зольность породы определяется следующим способом: параллельно хорде к6- $а$ (проекция которой на ось абсцисс представляет собой количество единиц в породе) проводится луч $A-M$, который на оси отсекает зольность породы $A=43,4 \%$.

Для оценки флотируемости можно использовать метод Ф.А. Зайнудинова, согласно которому обогатимость угля определяется выходом легких фракций $\boldsymbol{Y}_{\boldsymbol{n}}$ концентрата при заданной зольности.

При заданной зольности концентрата по кривой Майера возможно определить степень флотируемости. При легкой флотируемости возможно получение концентрата и породы, при средней - получение концентрата, промпродукта и породы. При трудной флотируемости зольность концентрата будет выше заданной.

\section{ЗАКЛЮЧЕНИЕ}

Обогатимость углей, определенная в соответствии с ГОСТ 10100-84 не характеризует уголь как сырье для обогащения, так как она не позволяет судить о возможности получения концентрата определенного качества. Степень загрязнения концентрата при обогащении различными методами показала, что она не определяется однозначно только содержанием промежуточных фракций в исходном сырье. Показатели выхода и зольности легких фракций (метод оценки обогатимости по Ф.А. Зайнудинову) по- зволяют судить о потенциальных значениях, количестве и качестве концентрата. Наиболее приемлем графический метод Бэрда для определения обогатимости угля. По этому методу степень трудности определяется содержанием смежных фракций \pm 100 кг/м³ на беспородную массу.

Предлагается конкретизировать пригодность метода с уточнением применения процессов обогащения и использования $E_{\rho m}$.

Для определения обогатимости угольной мелочи (шламов) крупностью 0-0,5 мм предлагается графический метод Майера. Кривая флотируемости кл. 0-0,5 мм основана на данных опытов дробной флотации. Степень флотируемости возможно определить по методу Ф.А. Зайнудинова по радиусу кривизны и по методу Грумбрехта по тангенсу угла смежных концентратов в интервале \pm 1 мин.

\section{Список литературы}

1. Павлович В.И., Фоменко Т.Г., Погарцева Е.М. Определение показателей обогащения углей. М.: Недра, 1966.

2. Черненко Б.Г., Шубан М.Б. Оценка кривых обогатимости угля по методу Бэрда / Сб. статей по обогащению углей. Харьков: Вып. ІІ ОНТИ, 1935.

3. ГОСТ 10100-84. Угли каменные и антрацит. Метод определения обогатимости.

4. ГайденрайхГ. Оценка промышленных результатов обогащения полезных ископаемых. М.: ГНТИ литературы по горному делу, 1962. 189 с.

5. Техника. Технология обогащения углей. Спр. пособие. М.: Наука, 1995.

6. Козлов В.А., Козлов Е.В. Выбор наиболее рациональных методов оценки обогатимости углей для практического применения при проектировании обогатительных фабрик // Горный информационно-аналитический бюллетень. 2012. Отдельный выпуск № 5. С. 265.

UDC 622.7.012.5 @ L.A. Antipenko, 2018

COAL PREPARATION

ISSN 0041-5790 (Print) • ISSN 2412-8333 (Online) • Ugol' - Russian Coal Journal, 2018, № 4, pp. 69-74

\section{Title}

\section{METHODS OF ASSESSMENT OF COAL WASHABILITY}

DOI: http://dx.doi.org/10.18796/0041-5790-2018-4-69-74

\section{Author}

Antipenko L.A. ${ }^{1}$

1 "Sibniiugleobogashenie" LLC, Prokopyevsk, 653000, Russian Federation

\section{Authors' Information}

Antipenko L.A., Doctor of Engineering Sciences, Professor, Adviser to General Director, e-mail: AntipenkoLA@suek.ru

\section{Abstract}

The paper is devoted graphical methods for determining the coal washability off Henry, Baird and Mayer. GOST 10100-84"Methods for determining of coa washability". It is based on the data graph of Henry and does not allow the most advantageous process for the separation of coal. For which reason This paper describes the alternative methods Baird and Mayer.

\section{Keywords}

Fractional composition, Floatability curve, Separation density, Coarseness of grading, Washability curve.

\section{References}

1. Pavlovich V.I., Fomenko T.G. \& Pogartsev E.M. Opredelenie pokazateley obogashcheniya ugley [Determination of technological characteristics coal washing]. Moscow, Nedra Publ., 1966.

2. Chernenko B.G. \& Shuban M.B. Otsenka krivykh obogatimosti uglya po metodu Berda [Evaluation of coal beneficiation curves according to Bird's method]. Sollection of articles on benefication of coals. Kharkov, Dept of Scientific and Technical Information Publ., 1935, Issue II.

3. GOST 10100-84 Hard coals and anthracite. Method for determining coal washability.

4. Gaydenraykh G. Otsenka promyshlennykh rezul'tatov obogashcheniya poleznykh iskopaemykh [Appraisal of industrial results of minerals processing]. Moscow, GNTI Publ., 1962, 189 p.

5. Tekhnika. Tekhnologiya obogashcheniya ugley [Equipment. Technology of coal washing], Handbook, Moscow, Nauka Publ., 1995.

6. Kozlov V.A. \& Kozlov E.V. Vybor naibolee ratsional'nykh metodov otsenki obogatimosti ugley dlya prakticheskogo primeneniya pri proektirovanii obogatitel'nykh fabrik [Selection of the most rational methods for determining coal washability for practical use when designing preparation plants]. Gornyy Informatsionno-Analiticheskiy Byulleten' - Mining Information and Analytical Bulletin, 2012, Separate issue No. 5, 265 p. 


\section{Обоснование технологии горнотехнической рекультивации в целях лесовосстановления на Крутокачинском щебеночном карьере}

\author{
ХАРИОНОВСКИЙ Анатолий Алексеевич \\ Доктор техн. наук, академик АГН, \\ заместитель генерального директора \\ по научной работе ООО «МНИИЭКО ТЭК», \\ 614007, г. Пермь, Россия, \\ e-mail:mniiekotek2009@yandex.ru
}

\section{ФРАНК Елена Яковлевна}

Канд. техн. наук, заместитель директора Института экономики и менеджмента, ФГБОУ ВО «СИбирский государственный индустриальный университет», 654007 , г. Новокузнечк, Россия

В статье представлены компоновочная схема горнопромышленного ландшафта в Крутокачинском щебеночном карьере по разработке доломитов после окончания горных работ в нем, а также объемы работ по горнотехнической рекультивации нерабочих бортов. Горнопромышленныйландшафтпредлагается обустроить с учетом географической ориентации нерабочих бортов карьера иминимальной площадью его дна для ускоренного самовосстановления лесной экосистемы. Ключевые слова: открытые горные работы, карьеры, конструкции нерабочих бортов карьера, горнотехническая рекультивачия, ландшафт после рекультивачии, экологические показатели, техногенная продуктивная смесь, лесные экосистемы.

\section{ВВЕДЕНИЕ}

В Красноярском крае более 100 лет разрабатывается Крутокачинское месторождение доломитов в 40 км на запад от г. Красноярска. Первые горные работы здесь начались в связи со строительством Транссибирской железнодорожной магистрали в конце XIX в., в 1960-е гг. они получили новый импульс к развитию. Горнопромышленный ландшафт, образованный в результате ведения горных работ, представлен карьерной выемкой и двумя внешними породными отвалами. За весь период разработки месторождения рекультивация нарушенных земель не проводилась. На территории нарушенных земель отсутствуют признаки самовосстановления растительного покрова. Вышесказанное позволяет сделать вывод о том, что на разрабатываемом месторождении необходима корректировка направления развития фронта горных работ в увязке с последующим проведением горнотехнического этапа рекультивации. Как показывает обзор спе- циальной литературы, аналогичные задачи в области экологии горного дела систематически решают как отечественные, так и зарубежные исследователи с представлением результатов в научных работах $[1,2,3,4,5,6,7,8,9,10,11,12,13]$.

\section{РЕШЕНИЕ ПРОБЛЕМЫ}

Особенностью горно-геологического строения месторождения является наличие трех вертикальных разломов, заполненных аргиллитами. Разломы шириной 40-60 м располагаются перпендикулярно линии фронта горных работ. В настоящее время горные работы производятся с предварительным рыхлением горных пород буровзрывным способом. Взрывные скважины бурят станком шарошечного бурения СБШ-250. В результате взрывного рыхления на уступах образуется развал горной породы с различным качеством доломитов. В зонах с разломами качество исходного горного сырья для производства щебня резко ухудшается и делает невозможным дальнейшее его использование. Эту часть доломитов, разубоженных аргиллитами, вывозят в отвалы, поскольку отраслевыми требованиями к качеству щебня для железных дорог запрещено наличие в нем аргиллитов.

В настоящее время длина фронта горных работ на карьере составляет 820 м, а глубина изменяется от 60 до 70 м. В разработке находятся семь уступов. Производственный потенциал карьера составляет 2 млн куб. м в год при организации горных работ в две смены. Экскавация горных пород производится экскаваторами ЭКГ-5А с погрузкой в автосамосвалы КрАЗ-6510 грузоподъемностью 14 т. Доломиты транспортируют на дробильно-сортировочные установки, вдоль которых проложены железнодорожные пути с выходом на транссибирскую магистраль. Общий вид Крутокачинского карьера со стороны восточного фланга показан на рис. 1.

В настоящее время площадь нарушенных земель составляет 38,3 га, из них площадь техногенного водоема - 3,8 га, площадь внешнего отвала «Северный» - 7 га, площадь отвала «Западный» - 1,7 га (рис. 2). Оставшаяся часть нарушенных земель представлена карьерной выемкой.

Предлагаемый порядок разработки месторождений с подвиганием горных работ на юг, юго-восток и восток представлен на рис. 2. Фигурными стрелками показаны выбранные направления развития горных работ.

Площадь горнопромышленного ландшафта на конец отработки участка месторождения составит 68 га. Размер площади внешних отвалов «Западный» и «Северный» не изменится. На территории карьера предлагается отсыпать внутренний отвал в один ярус переменной высоты площадью 15,7 га. За счет отсыпки внутреннего отвала площадь техно- 

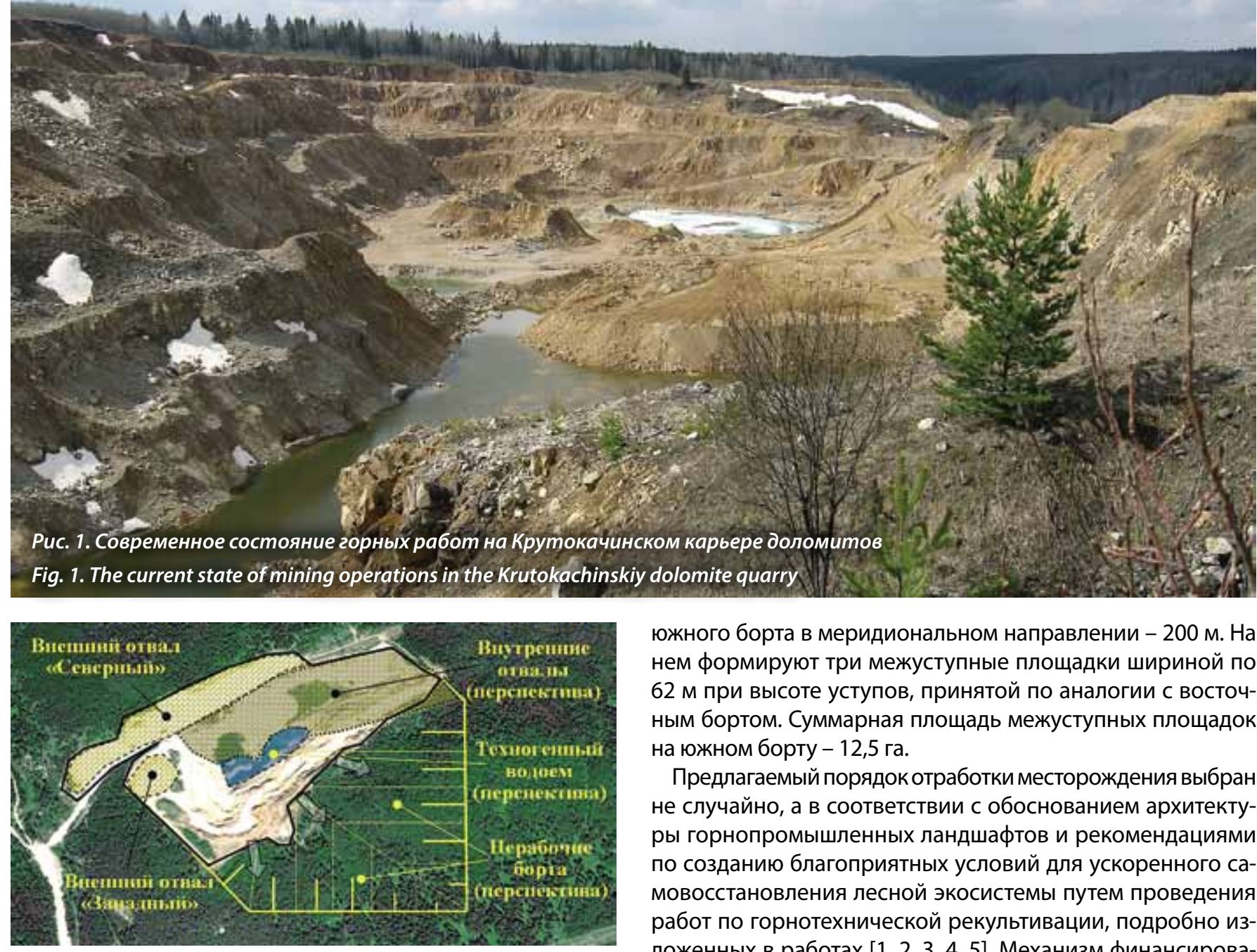

Puc. 2. Компоновочная схема Крутокачинского карьера на момент завершения горных работ с выделением элементов горнопромышленного ландшафта

Fig. 2. The layout diagram of the Krutokachinskiy quarry at the time of completion of mining operations with highlighting of the mining landscape elements

генного водоема сократится до 1,8 га (2,65 \%). В конструкции остаточной карьерной выемки предусмотрено оформить восточный борт площадью 22,8 га с ориентацией на запад, а также южный борт площадью 13,3 га. Площадь западного борта останется на современном уровне 5,8 га. При отсыпке внутреннего отвала должен соблюдаться уклон его поверхности в восточном направлении. Размер восточного борта в направлении с запада на восток - 420 м, а это значит, что имеется конструктивная возможность его оформления в виде трех межуступных площадок шириной 126 м каждая.

Высота всех уступов кроме нижнего в нерабочем состоянии - 20 м (сдвоенные), а нижнего - 10 м. Суммарная площадь межуступных площадок на восточном борту - 21,2 га. Размер

\section{Прогнозные показатели работ по горнотехнической рекультивации в Крутокачинском карьере}

\section{Показатель}

Мощность наносимой продуктивной смеси, м:

\begin{tabular}{l|c}
\hline - на межуступные площадки западного борта & 0,6 \\
\hline - на межуступные площадки южного борта & 1,0 \\
\hline $\begin{array}{l}\text { - на межуступные площадки восточного борта } \\
\text { Прогнозное количество деревьев в лесной экоси- }\end{array}$ & 20045 \\
\hline $\begin{array}{l}\text { стеме (смешанный лес) на межуступных площадках } \\
\text { карьера согласно данным в работах [1, 2, 3, 4, 5] }\end{array}$ & \\
\hline $\begin{array}{l}\text { Продуктивность травянистого покрова } \\
\text { (западный борт), ц/га }\end{array}$ & $25-26$ \\
\hline
\end{tabular}

южного борта в меридиональном направлении - 200 м. На нем формируют три межуступные площадки шириной по 62 м при высоте уступов, принятой по аналогии с восточным бортом. Суммарная площадь межуступных площадок на южном борту - 12,5 га.

Предлагаемый порядок отработки месторождения выбран не случайно, а в соответствии с обоснованием архитектуры горнопромышленных ландшафтов и рекомендациями по созданию благоприятных условий для ускоренного самовосстановления лесной экосистемы путем проведения работ по горнотехнической рекультивации, подробно изложенных в работах [1, 2, 3, 4, 5]. Механизм финансирования работ по рекультивации земель на этом карьере может быть принят по аналогии с ранее разработанным для угольных разрезов [6]. Прогнозные показатели самовосстановления лесной экосистемы при ведении горных работ по разработанному варианту представлены в таблице. Рекомендации по формированию продуктивной смеси для ее нанесения на межуступные площадки приняты в соответствии с источниками $[1,2,3,4,5]$.

Отметим, что карьер находится в окружении черневой тайги с преобладанием темнохвойных пород - ели, пихты, кедра. Поэтому создание условий для самовосстановления лесной экосистемы на заключительном этапе отработки этого месторождения должно носить приоритетный характер.

\section{ЗАКЛЮЧЕНИЕ}

Таким образом, в статье наглядно показана возможность ускоренного самовосстановления лесной экосистемы на территории карьера по разработке доломитов после завершения в нем горных работ. Этому должны способствовать порядок отработки месторождения, а также обязательное проведение горнотехнической рекультивации, обеспечивающей улучшение экологической обстановки в районе производства открытых горных работ.

\section{Список литературы}

1. Зеньков И.В., Барадулин И.М. Обоснование конечной формы щебеночных карьеров Сибири в целях лесотехнической рекультивации // Горный журнал. 2016. № 3. С. 85-88.

2. Zenkov I.V., Yuronen Yu.P., Nefedov B.N., Baradulin I.M. Remote sensing in estimation of forest ecosystem generation at crushed stone quarries in Siberia // Eurasian mining. 2016. № 1. P. 50-54. 
3. Зеньков И.В., Барадулин И.М. Результаты исследования условий появления и формирования растительного покрова в отработанных щебеночных карьерах //Уголь. 2017. № 12 C.69-71.URL: http://www.ugolinfo.ru/Free/122017.pdf (дата обращения: 15.02.2018).

4. Зеньков И.В., Барадулин И.М. Обоснование горнотехнической рекультивации карьеров по добыче нерудных материалов для производства щебня //Уголь. 2018. № 2. С. 96-99. doi: 10.18796/0041-5790-2018-2-96-99

5. Зеньков И.В., Барадулин И.М.Исследование условий формирования и характеристик лесных экосистем в отработанных щебеночных карьерах в Красноярском крае // Уголь. 2018. № 1. C. 81-83. doi: 10.18796/0041-5790-2018-1-81-83.

6. Петрова Т.В., Франк Е.Я. Регулирование процесса обеспечения денежными средствами работ по рекультивации земель. // Горный информационно-аналитический бюллетень. 2016. № 3. С. 76-84.

7. Яновский А.Б. Основные тенденции и перспективы развития угольной промышленности России // Уголь. 2017. № 8. C.10-14. doi: 10.18796/0041-5790-2017-8-10-14. URL: http://www.ugolinfo.ru/Free/082017.pdf (дата обращения: 15.02.2018).
8. Таразанов И.Г. Итоги работы угольной промышленности России за январь-сентябрь 2017 года // Уголь. 2018. № 1. C. 18-32. doi: 10.18796/0041-5790-2018-1-18-32

9. Naeth M.A., Wilkinson S.R. Establishment of Restoration Trajectories for Upland Tundra Communities on Diamond Mine Wastes in the Canadian Arctic // Restoration Ecology. 2014. Vol. 22(4). P. 534-543.

10. Sena K., Barton C., Hall S., Angel P., Agouridis C., Warner $R$. Influence of spoil type on afforestation success and natural vegetative recolonization on a surface coal mine in Appalachia, United States // Restoration Ecology. 2015. Vol. 23(2). P. 131-138.

11. Gilland K.E., McCarthy B.C. Microtopography Influences Early Successional Plant Communities on Experimental Coal Surface Mine Land Reclamation // Restoration Ecology. 2014. Vol. 22(2). P. 232-239.

12. Zhang Hao, Zhuang Xueying, Chu L.M. Plant Recruitment in Early Development Stages on Rehabilitated Quarries in Hong Kong // Restoration Ecology. 2013. Vol. 21(2). P. 166-173.

13. Ngugil M.R., NeldnerV.J., Doley D., Kusy B., Moore D., Richter C. Soil moisture dynamics and restoration of self-sustaining native vegetation ecosystem on an open-cut coal mine // Restoration Ecology. 2015. Vol. 23(5). P. 615-624.

UDC 622.882:622.271.3 @ A.A. Kharionovsky, E.Ya. Frank, 2018

ECOLOGY

ISSN 0041-5790 (Print) • ISSN 2412-8333 (Online) • Ugol' - Russian Coal Journal, 2018, № 4, pp. 75-77

\section{Title}

VALIDATION OF THE TECHNOLOGY OF MINE TECHNICAL RECLAMATION FOR THE PURPOSE OF REFORESTATION IN THE KRUTOKACHINSKIY BALLAST QUARRY

DOI: http://dx.doi.org/10.18796/0041-5790-2018-4-75-77

\section{Authors}

Kharionovsky A.A. ${ }^{1}$, Frank E.Ya. ${ }^{2}$

1 "MNIIEKO TEK", LLC, Perm, 614007, Russian Federation

${ }^{2}$ Institute of Economics and Management at FSBEl of Higher Education "Siberian State Industrial University", Novokuznetsk, 654007, Russian Federation

\section{Autors Information}

Kharionovsky A.A., Doctor of Engineering Sciences, Deputy General Director, Academy Fellow of the Academy of Mining Sciences, e-mail: mniiekotek2009@ yandex.ru

Frank E.Ya., PhD (Engineering), Deputy Director

\section{Abstract}

The paper presents the layout diagram of the mining landscape in the Krutokachinskiy dolomite ballast quarry after mining operations therein, as well as the scope of work for mine technical reclamaation of non-mining flanks. The mining landscape is proposed to be arranged given the geographic orientation of opencast non-mining flanks and the minimum area of its bottom for the accelerated self-restoration of the forest ecosystem.

Figures:

Fig. 1. The current state of mining operations in the Krutokachinskiy dolomite quarry Fig. 2. The layout diagram of the Krutokachinskiy quarry at the time of completion of mining operations with highlighting of the mining landscape elements

\section{Keywords}

Surface mining, Quarries, Construction of non-mining opencast flanks, Mine technical reclamation, Post-reclamation landscape, Ecological indicators, Technogenic productive mixture, Forest ecosystems.

\section{References}

1.Zenkov I.V.\& Baradulin I.M. Obosnovanie konechnoy formy shchebenochnykh kar'erov Sibiri v tselyakh lesotekhnicheskoy rekul'tivatsii [Ultimate pit limit substantiation for the purpose of forestry reclamation of lands at ballast quarries in Siberia]. Gornyi Zhurnal - Mining Journal, 2016, No. 3, pp. 85-88.

2. Zenkov I.V., Yuronen Yu.P., Nefedov B.N. \& Baradulin I.M. Remote sensing in estimation of forest ecosystem generation at crushed stone quarries in Siberia. Eurasian mining, 2016, No. 1, pp. 50-54.

3.Zenkov I.V.\& Baradulin I.M. Rezul'taty issledovaniya usloviy poyavleniya i formirovaniya rastitel'nogo pokrova v otrabotannykh shchebenochnykh kar'erakh [Study results of vegetation emergence and formation in depleted crushed stone quarries]. Ugol' - Russian Coal Journal, 2017, No. 12, pp. 69-71. Available at: http:// www.ugolinfo.ru/Free/122017.pdf (accessed 15.02.2018).

4. Zenkov I.V. \& Baradulin I.M. Obosnovanie gornotekhnicheskoy rekul'tivatsii kar'erov po dobyche nerudnykh materialov dlya proizvodstva shchebnya [Substantiation of mining-engineering reclamation of nonmetallic materials quarries for ballast production]. Ugol' - Russian Coal Journal, 2018, No. 2, pp. 96-99. doi: 10.18796/0041-5790-2018-2-96-99

5. Zenkov I.V. \& Baradulin I.M. Issledovanie usloviy formirovaniya i kharakteristik lesnykh ekosistem $v$ otrabotannykh shchebenochnykh kar'erakh v Krasnoyarskom krae [Study results of vegetation emergence and formation in depleted crushed stone quarries in Krasnoyarsk Krai]. Ugol' - Russian Coal Journal, 2018, No. 1, pp. 81-83. doi: 10.18796/0041-5790-2018-1-81-83.

6. Petrova T.V., Frank E.Ya. Regulirovanie protsessa obespecheniya denezhnymi sredstvami rabot po rekul'tivatsii zemel' [Control of the process of providing funds for land reclamation]. Gornyy Informatsionno-Analiticheskiy Byulleten' - Mining Information and Analytical Bulletin, 2016, No. 3, pp. 76-84.

7. Yanovsky A.B. Main trends and prospects of the coal industry development in Russia. Ugol' - Russian Coal Journal, 2017, No. 8, pp. 10-14. doi: 10.18796/00415790-2017-8-10-14. Available at: http://www.ugolinfo.ru/Free/082017.pdf (accessed 15.02.2018).

8. Tarazanov I.G. Russia's coal industry performance for January - September, 2017. Ugol' - Russian Coal Journal, 2018, No. 1, pp. 18-32. doi: 10.18796/00415790-2018-1-18-32.

9. Naeth M.A. \&Wilkinson S.R. Establishment of Restoration Trajectories for Upland Tundra Communities on Diamond Mine Wastes in the Canadian Arctic. Restoration Ecology, 2014, Vol. 22(4), pp. 534-543.

10. Sena K., Barton C., Hall S., Angel P., Agouridis C. \& Warner R. Influence of spoil type on afforestation success and natural vegetative recolonization on a surface coal mine in Appalachia, United States. Restoration Ecology, 2015, Vol. 23(2), pp. 131-138.

11. Gilland K.E. \& McCarthy B.C. Microtopography Influences Early Successional Plant Communities on Experimental Coal Surface Mine Land Reclamation. Restoration Ecology, 2014, Vol. 22(2), pp. 232-239.

12. Zhang Hao, Zhuang Xueying \& Chu L.M. Plant Recruitment in Early Development Stages on Rehabilitated Quarries in Hong Kong. Restoration Ecology, 2013, Vol. 21(2), pp. 166-173.

13. Ngugil M.R., Neldner V.J., Doley D., Kusy B., Moore D. \& Richter C. Soil moisture dynamics and restoration of self-sustaining native vegetation ecosystem on an open-cut coal mine. Restoration Ecology, 2015, Vol. 23(5), pp. 615-624. 


\section{Всероссийские «рельсовые войны» шахтеров в мае 1998 года}

DOI: http://dx.doi.org/10.18796/0041-5790-2018-4-78-80

\author{
РОЖКОВ Анатолий Алексеевич \\ Доктор экон. наук, профессор \\ Института экономики и управления \\ промышленными предприятиями НИТУ «МИСИС》, \\ 119049, г. Москва, Россия, тел.: +7 (499) 230-24-78, \\ e-mail:aarozhkov@mail.ru
}

\section{СОЛОВЕНКО Игорь Сергеевич}

Доктор истор. наук, дочент

Юргинского технологического института (филиала)

ФГАОУ ВО «Национальный исследовательский

Томский политехнический университет",

652055, г. Юрга, Россия, тел.: +7 (38451) 7-77-62,

e-mail: solovenko71@mail.ru

\section{МАРЧУК Вероника Ивановна \\ Старший преподаватель \\ Юргинского технологического института (филиала) \\ ФГАОУ ВО «Начиональный исследовательский \\ Томский политехнический университет», \\ 652055, г. Юрга, Россия, тел.: +7 (38451) 7-77-62, \\ e-mail: tika75-1977@mail.ru}

\section{СУЗДАЛОВА Марина Анатольевна}

Канд. пед. наук, дочент

Юргинского технологического института (филиала)

ФГАОУ ВО «Национальный исследовательский

Томский политехнический университет",

652055, г. Юрга, Россия, тел.: +7 (38451)7-77-62,

e-mail:marinasuzdalova@rambler.ru
Статья посвящена 20-летию всероссийских «рельсовых войн», которые явились пиком протестного движения шахтеров в постсоветский период. Рассматриваются основные причины протеста, его основные очаги и последствия. Делается вывод о том, что, несмотря на широкий спектр политическихлозунгов участников шахтерских пикетов, органам власти удалось достичь с ними компромисса посредством социально-экономических уступок и преобразований.

Ключевые слова: Россия, переход к рынку, угольная промышленность, шахтеры, протесты, «рельсовые войны».

\section{ВВЕДЕНИЕ}

Всероссийские «рельсовые войны» в мае 1998 г. являются пиком протестного движения шахтеров России в постсоветский период. Главной проблемой рабочих угольной промышленности являлись многомесячные задержки по выплате заработной платы.

\section{ХРОНИКА СОБЫТИЙ}

Инициаторами «рельсовых войн» стали горняки приполярного города Инта, организовавшие в начале мая серию резонансных выступлений. Несмотря на многочисленные обещания, их требования так и не были выполнены. Поэтому 13 мая шахтеры совместно с учителями и медицинскими работниками перекрыли железнодорожную ветку МоскваВоркута-Лабытнанги и заблокировали весь регион угледобычи в Республике Коми. Количество интинцев, участвовавших в акции протеста на рельсах, достигло 2000 чел. [1, с. 66].

Акции протеста горняков, в том числе и на рельсах, распространялись стихийно, охватывая все новые города и поселки фактически всех углепромышленных территорий. 15 мая анжеро-судженские горняки перекрыли Транссиб. Кузбасские пикетчики в жесткой форме выдвинули социально-экономические и политические требования [2].

Третьим крупным очагом всероссийской акции протеста горняков стала Ростовская область, где 18 мая было остановлено движение по Северокавказской железной дороге. В результате перекрытия рельсов на станции г. Шахты было задержано отправление более 300 грузовых и 280 пассажирских поездов. Шахтинцев поддержали горняки и регрессники соседних городов - Новошахтинска, Гуково и Красного Сулина. В течение дня здесь собралось около 3000 чел. [3, с. 4].

Самые драматические события развернулись в ведущем углепромышленном регионе страны. Пик солидарности кузбасских трудящихся приходится на 20 мая. В тот день реальную поддержку Анжеро-Судженску оказали такие города, как Прокопьевск, Киселевск и Юрга. Южную ветку Кузбасского отделения Западносибирской железной дороги одновременно перекрыли сотни прокопьевских горняков, коммунальщиков и медиков [4]. В итоге блокировалось «Большое сибирское кольцо», то есть железнодорожные пути, которые пронизывают Кемеровскую область, в том числе и часть Транссиба. Соответственно, прервалось железнодорожное сообщение не только по территории области, но и всей страны.

В результате перекрытия Транссиба на Западносибирском участке железной дороги было остановлено движение почти 300 пассажирских и свыше 350 грузовых составов. Ежесуточные потери от простоя поездов составляли более 1,5 млн руб. [5, с. 241]. Обстановка продолжала усугубляться: 22 мая на рельсы вышли шахтеры г. Междуреченска. В результате железнодорожные перевозки в Кузбассе оказались полностью парализованы.

Обострялась обстановка и в Ростовской области. 20 мая объездной участок вокруг г. Шахты, который все-таки использовался железнодорожниками с момента начала «рельсовой войны», также был перекрыт [6]. В итоге главный железнодорожный «ход», связывающий центр с югом России, был полностью закрыт. 


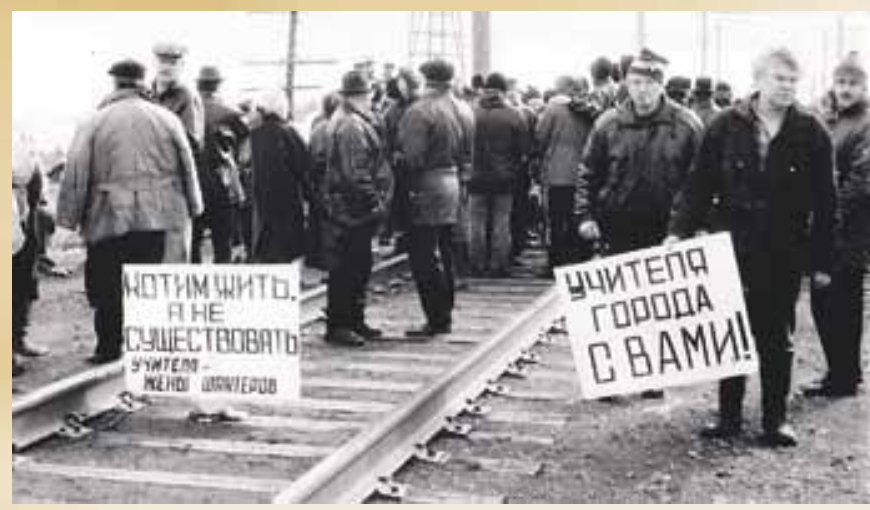

Перекрытие Транссиба в районе г. Анжеро-Судженска (фото предоставлено Городским краеведческим музеем 2. Анжеро-Судженска)

Блокады важных транспортных магистралей, а также другие массовые и радикальные акции протеста рабочих угольной промышленности прокатились по всей стране. Почувствовав растерянность правительственных комиссий в местах проведения «рельсовых войн», шахтеры выдвигали новые, трудновыполнимые требования: существенное увеличение финансирования отрасли и быстрейшее погашение задолженности по зарплатам. Усиливалась значимость политических лозунгов (импичмент Президенту, перераспределение властных полномочий, национализация угольной промышленности и др.).

Федеральная власть теряла контроль над ситуацией. Железнодорожные блокады поставили на грань выживания сотни предприятий и организаций страны. Вместе с тем еще большую обеспокоенность для россиян представляла судьба пассажиров, оказавшихся в железнодорожном плену. 22-23 мая «рельсовые войны» угрожали экономической целостности, социально-политической стабильности, а «в ряде случаев и национальной безопасности» страны [7, с 1]. В тот критический момент все россияне услышали радиообращение Б. Ельцина с призывом прекратить блокады железнодорожных магистралей. Глава государства заявил о «необходимости навести порядок в шахтерской отрасли» [8].

\section{ИТОГИ ПРОТЕСТНЫХ АКЦИЙ}

Несмотря на масштабность всероссийской акции протеста, она имела ряд слабостей, которые не позволили добиться реализации ключевых требований пикетчиков. Вопервых, лидеры территориальныхпрофсоюзных организаций, претендовавшие на роль координаторов всероссийской акции протеста, в реальности боялись взять на себя эту задачу [9, с. 26]. Во-вторых, участие горняков во всероссийской акции протеста было неоднородным. География борьбы показывает, что наиболее активные действия в акциях протеста предпринимались в Печорском угольном бассейне, Кузбассе и Российском Донбассе, где имелась высокая концентрация рабочих-горняков. В разных формах протеста активно поддержали «рельсовые войны» работники угольной промышленности Южного Урала, Приморья и Сахалина. Низкая степень участия либо только моральная поддержка всероссийской акции протеста имела место среди горняков Подмосковья, Поволжья, Хакасии и некоторых других шахтерских территорий. В-третьих, непоследовательное поведение самих участников «рельсовых войн». Рабочие угледобывающей отрасли не стали вырази-

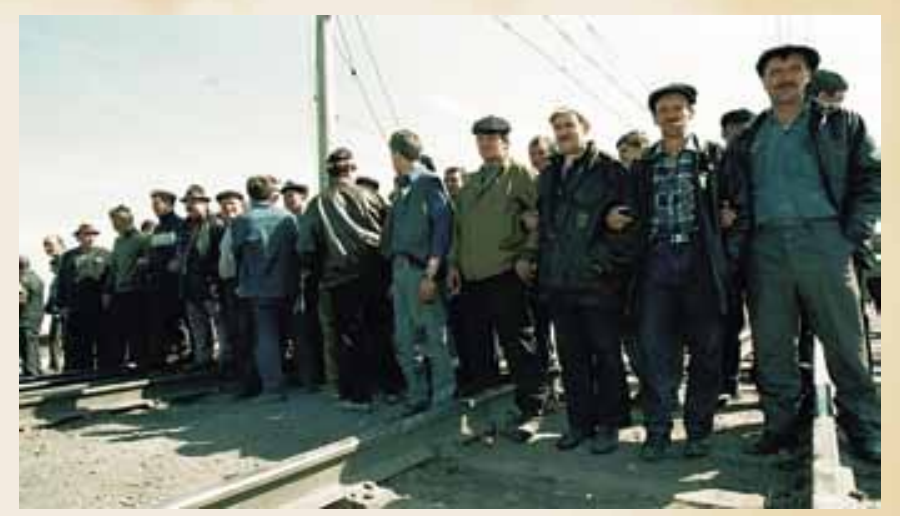

Перекрытие Транссиба (фото из газеты «Аргументы и факты», WWW.KUZBASS.AIF.RU)

телями экономических и политических намерений трудящихся других отраслей и представителей бюджетных организаций. Они, с одной стороны, требовали отставки Президента Ельцина, с другой - настаивали на быстром погашении задолженности по зарплате и оказании всевозможной финансово-материальной помощи тем же Президентом. Таким образом, всем стала очевидна неуверенность пикетчиков в своих политических требованиях, их готовность обменять лозунг «Долой Президента Ельцина!» на погашение долгов по зарплате. В критический для страны момент шахтеры не особо скрывали приоритет своих материальных интересов над политическими.

Непоследовательное поведение шахтеров стало сигналом не только всей вертикали власти, но и общественным, а также политическим силам, которые на тот момент поддерживали пикетчиков. Почувствовав разобщенность, руководство страны выстроило свою стратегию нейтрализации борьбы так, чтобы рабочие угольной промышленности оказались изолированы друг от друга. В то же время Правительство РФ, как никогда ранее, решало главный вопрос озлобленных шахтеров - погашение задолженности по зарплате.

Первой, после пяти суток и семи часов блокады, была «освобождена» Северокавказская железная дорога. Второй крупной победой органов власти стало «открытие» Транссиба 24 мая.

Дольше других руководству страны и региональным органам власти пришлось искать компромисс с шахтерами Республики Коми. Несмотря на слабую уступчивость правительственной комиссии, шахтеры Инты были вынуждены свернуть блокаду Северной железной дороги (25 мая), так как ни сил, ни поддержки у них уже не было. Они поддержали инициативу НПГ России - организовать всероссийский пикет перед Домом Правительства РФ.

\section{ЗАКЛЮЧЕНИЕ}

В условиях огромной, неравномерно развитой экономики и транспортной системы «поднять» страну на протест посредством «рельсовых войн» явилось для шахтеров непосильной задачей. Блокады железных дорог оказались действенным (и, пожалуй, единственно эффективным) средством заставить власти и работодателей искать пути выхода из кризиса невыплаты заработной платы. Правительством РФ была оказана мобильная помощь и поддержка даже тем шахтерским городам и поселкам, которые приняли в то время опосредованное участие в про- 
тестном движении. Кроме того, ускорилось проведение эффективных рыночных преобразований, началась форсированная приватизация, реструктуризация отрасли стала социально ориентированной и т.д.

Пик протестного движения шахтеров постсоветской России сопровождался и не менее широким спектром негативных последствий. Шахты и разрезы, чьи рабочие участвовали в акциях протеста, столкнулись с многомиллионными экономическими потерями, снизили свои конкурентные преимущества на внутреннем и внешнем рынках. Затянувшаяся борьба шахтеров привела к ощутимым экономическим потерям во многих других отраслях народного хозяйства, прежде всего углепромышленных регионов.

Итак, результаты всероссийских «рельсовых войн» шахтеров являлись неоднозначными. Хотя власть и пошла на уступки, но в большей мере они имели социальноэкономическое содержание, нежели политическое. Между тем этого оказалось достаточно для снижения количества акций протеста шахтеров в последующие годы.

\section{Список литературы}

1. День шахтера (реструктуризация угольной промышленности глазами участников и журналистов). М., 2004. 132 с.

2. Прянишникова Т. От забоя - на площадь, с площади на рельсы // Наш город (Анжеро-Судженск, Кемеровская область). 1998. 16 мая.

3. Горбанева С. Борис Немцов в Шахтах: взгляд из 1998го... // Пласт (Ростов-на-Дону). 2015. 15 марта.

4. Фомичева Т. Большое кольцо замкнулось // Кузбасс (Кемерово). 1998. 21 мая.

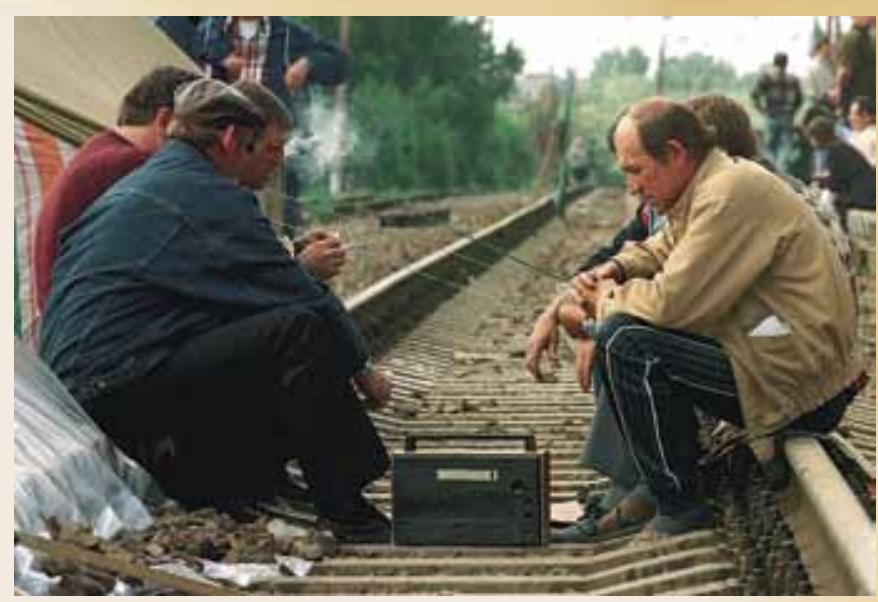

Перекрытие железной дороги в районе г. Шахты (Ростовская область), фото из Интернета

5.Угольный Кузбасс: страницы истории. Кемерово, 2005.428с.

6. Смысленко О. Пассажиры на Лихой уже хлебнули лиха... // Вечерний Ростов (Ростов-на-Дону). 1998. 21 мая.

7. Огурцов В. Чуда не будет, но деньги можно найти // Российская газета. 1998. 26 мая.

8. Горбунов В. Шахтеры наступили на горло правительственной песне // Контакт (Междуреченск, Кемеровская область). 1998. 26 мая.

9. Постановление пленума Кемеровского обкома КПРФ «О политической и социально-экономической ситуации в России, Кузбассе и задачах партийной организации», г. Кемерово, 30 мая 1998 г. / Государственный архив Кемеровской области. Ф. 1311. Оп. 1.Д. 75.

UDC 94(470):622.33«1998»:658.016.7:331.2 @ A.A. Rozhkov, I.S. Solovenko, V.I. Marchuk, M.A. Suzdalova, 2018

CHAPTER IN HISTORY ISSN 0041-5790 (Print) • ISSN 2412-8333 (Online) • Ugol' - Russian Coal Journal, 2018, № 4, pp. 78-80

\section{Title}

\section{ALL-RUSSIAN “RAIL WARS” OF MINERS IN MAY 1998}

DOI: http://dx.doi.org/10.18796/0041-5790-2018-4-78-80

\section{Authors}

Rozhkov A.A. ${ }^{\text {, }}$ Solovenko I.S. ${ }^{2}$, Marchuk V.I. ${ }^{2}$, Suzdalova M.A. ${ }^{2}$

${ }^{1}$ National University of Science and Technology "MISIS" (NUST "MISIS"), Moscow, 119049, Russian Federation

${ }^{2}$ Yurginsky Institute of Technology (branch) of FSAEI HE "National Research Tomsk Polytechnic University", Yurga, 652055, Russian Federation

\section{Authors' Information}

Rozhkov A.A., Doctor of Economic Sciences, Professor, Institute of Economics and Management of Industrial Enterprises, tel.: +7 (499) 230-24-78,

e-mail: aarozhkov@mail.ru

Solovenko I.S., Doctor of History Sciences, Assistant Professor tel.: +7 (38451) 7-77-62, e-mail: solovenko71@mail.ru

MarchukV.I., Senior teacher, tel.: +7 (38451) 7-77-62, e-mail: tika75-1977@mail.ru

Suzdalova M.A., PhD (Pedagogical), Assistant Professor,

tel.: +7 (38451)7-77-62, e-mail: marinasuzdalova@rambler.ru

\section{Abstract}

The paper is devoted to the 20th anniversary of the All-Russian "rail wars", which became the peak of the protest movement of miners in the post-Soviet period. It considers the main reasons of the protest, its key storm centres and consequences. It draws the conclusion that, despite the wide range of political slogans of the participants in the mines pickets, the authorities succeeded in reaching a compromise with them through socio-economic concessions and reforms.

\section{Keywords}

Russia, Transition to the market economy, Coal industry, Miners, Protests, "Rail wars".

\section{References}

1.Den'shakhtera (restrukturizatsiya ugol'noy promyshlennostiglazamiuchastnikov izhurnalistov) [Miner's Day (restructuring of the coal industry through the eyes of participants and journalists)]. Moscow, 2004, 132 p.
2. Pryanishnikova T. Ot zaboya - na ploshchad', s ploshchadi - na rel'sy [From the face to the square, from the square onto the rails]. Nash gorod-Our city (AnzheroSudzhensk, Kemerovo region), 1998, May 16.

3. Gorbaneva S. Boris Nemtsov v Shakhtakh: vzglyad iz 1998-goda... [Boris Nemtsov in Shakhty: as seen in 1998 ...]. Plast-Seam (Rostov-on-Don), 2015, March 15 4. Fomicheva T. Bol'shoe kol'tso zamknulos' [The big ring has become isolated]. Kuzbass (Kemerovo), 1998, May 21.

5. Ugol'nyy Kuzbass: stranitsy istorii [Coal Kuzbass: pages of history]. Kemerovo 2005, $428 \mathrm{p}$.

6. Smyslenko O. Passazhiry na Likhoy uzhe khlebnuli likha... [Passengers at Likhaya have already smelled hell...]. Vecherniy Rostov - The Evening Rostov (Rostov-onDon), 1998, May 21.

7. OgurtsovV. Chuda ne budet, no den'gi mozhno nayti [There will be no miracle, but the money may be found]. Rossiyskaya Gazeta - Russian newspaper, 1998, May 26. 8. Gorbunov V. Shakhtëry nastupili na gorlo pravitel'stvennoy pesne [The miners put the lid on the government's desires]. Kontakt - Contact (Mezhdurechensk, Kemerovo region), 1998, May 26.

9. Postanovlenieplenuma Kemerovskogoobkoma KPRF "Opoliticheskoyisotsial'no-ekonomicheskoy situatsiiv Rossii, Kuzbasseizadachakh partiynoyorganizatsii", Kemerovo, 30 maya 1998 [Resolution of the plenum of the Kemerovo Regional Committee of the Communist Party of the Russian Federation "On political and socio-economic situation in Russia, Kuzbass and on the party organization objectives", Kemerovo, May 30, 1998]. State Archive of the Kemerovo Region, Vol. 1311, Inv. 1, D. 75.

\section{Acknowledgments}

The research is carried out at Tomsk Polytechnic University within the framework of Tomsk Polytechnic University Competitiveness Enhancement Program grant. 


\section{СУЭК представила в Кемерово фотовыставку, посвященную шахтерскому труду}

В Кемеровском областном музее изобразительных искусств при поддержке Администрации Кемеровской области в начале марта 2018 г. открылась выставка «Люди угля». В фотопроект вошли 88 фоторабот известного фотографа-индустриалиста Максима Мармура, съемки которых велись на добывающих, перерабатывающих и транспортных предприятиях Сибирской угольной энергетической компании в восьми регионах России, в том числе и в Кузбассе.

Пришедшие на выставку посетители оценили ее как своеобразную фотографическую поэму, посвященную героям шахтерской профессии. Снимки показывают, насколько с приходом новых технологий изменился труд горняков. Но при этом профессия по-прежнему остаётся одной из самых сложных, напряженных, требующих большой самоотдачи. На больших портретах, выполненных в черно-белом формате, показаны люди со своими эмоциями, усталостью и радостями.

Поздравляя с открытием выставки, заместитель губернатора Кемеровской области Елена Пахомова сказала: «Шахтер - главная профессия для Кузбасса. Практически каждая семья так или иначе связана с углем. Но далеко не каждому удается увидеть, как под землей добывается этот уголь, что стоит за шахтерскими рекордами. Сегодняшняя выставка благодаря мастерству фотографа Максима Мармура дает такую возможность. Ощутить напряжение труда, восхититься мужеством и открытостью горняков. Настоящих героев нашего времени. Замечательно, что выставка проходит в год празднования 75-летия Кемеровской области. Она еще раз наглядно показывает, особенно молодомупоколению, - мы живем в шахтерском крае».

В открытии выставки приняли участие сами герои работ - горняки шахт имени В.Д. Ялевского, имени С.М. Кирова, «Талдинская-Закладная - 2», разреза «Заречный». По их мнению, фотографии позволяют по-другому взглянуть на свою работу, на коллег, увидеть необычное, яркое в том, что давно стало привычным.

«Проект «Люди угля», длящийся почти три года, показывает «героику будней» шахтерского труда, - говорит генеральный директор АО «СУЭК-Кузбасс» Евгений Ютяев. - И в этом его главная ценность. Выставка дает масштабное представление о том, какая она - современная угольная отрасль, и какой он - современный шахтер».

В рамках работы фотовыставки Максим Мармур также провел мастер-класс для студентов факультета визуальных искусств Кемеровского государственного института культуры.

Впервые работы из этого проекта были представлены в 2016 г. на Международном фестивале фотографии PhotoVisa. В 2017 г. «Люди угля» были выставлены на Итальянском фотографическом профессиональном форуме FIOF в Орвието, после чего совершили турне по другим городам Италии.

Осенью пошлого года проект «Люди угля» вошел в экспозицию выставки «Гордость России - шахтеры», которая прошла в Центральном доме художника в Москве и была посвящена юбилею празднования Дня шахтера. В 2018 г. выставка, начиная с Кузбасса, пройдет также в других регионах России и в Китае.

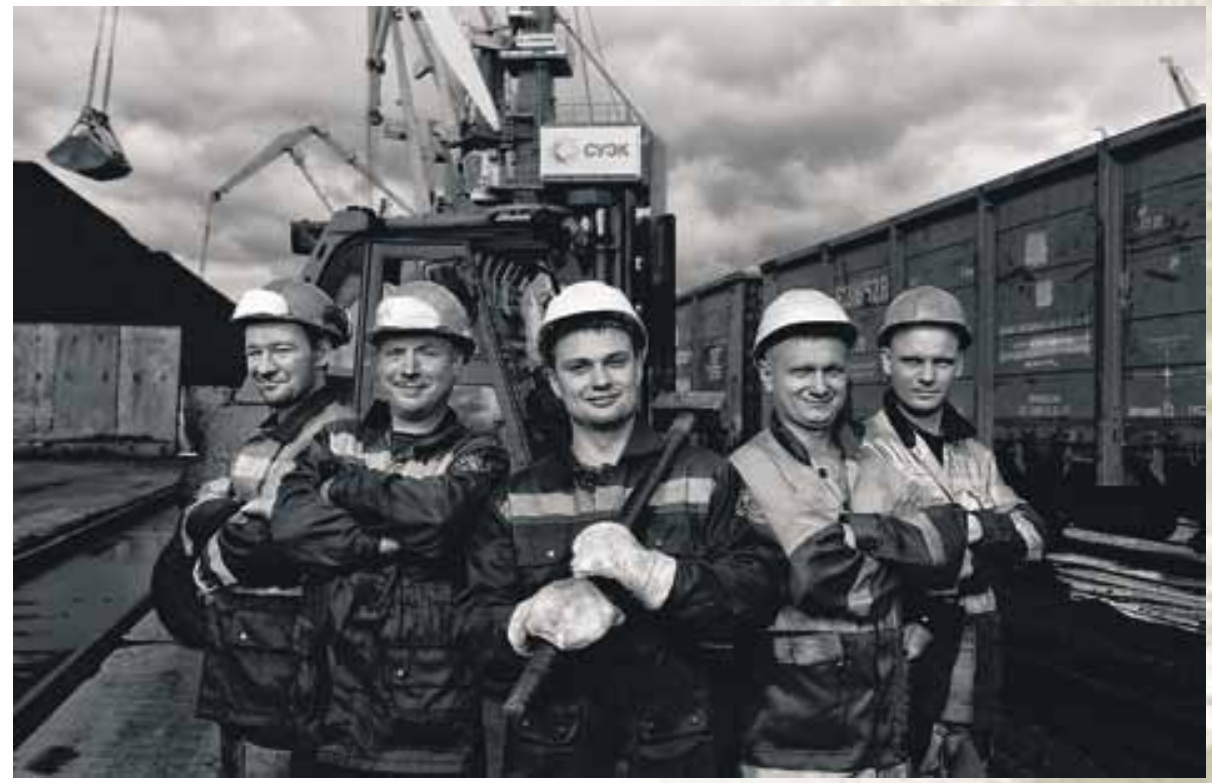




\section{К 100-летию со дня рождения профессора БЛАГОВА Игоря Сильвестровича}

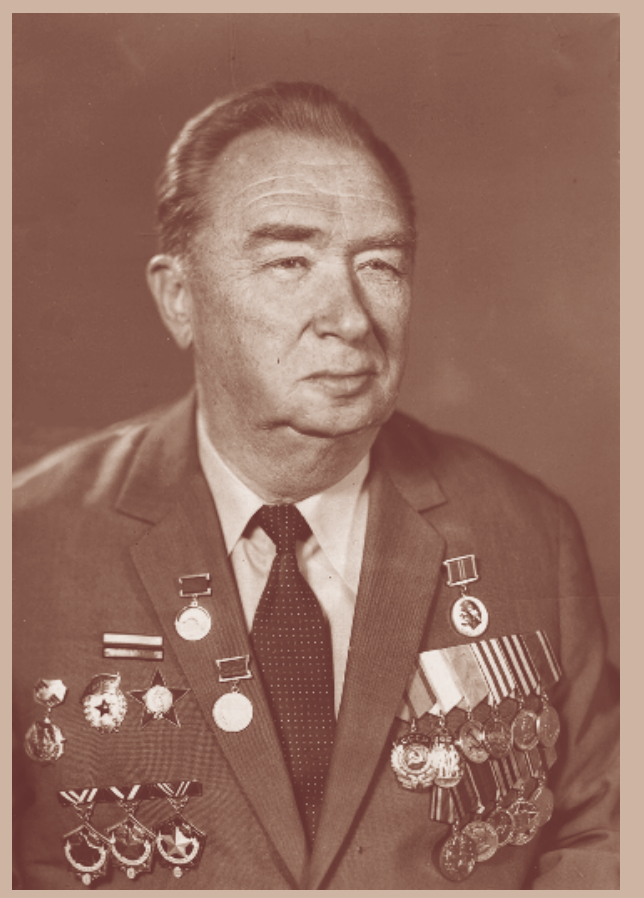

\section{(1918 - 1987)}

29 мая 2018 г. исполняется 100 лет со дня рождения известного ученого, крупного руководителя и организатора одной из ведущих отраслей угольной промышленности - углеобогащения, кандидата технических наук, профессора Игоря Сильвестровича Благова.
Более сорока лет своей трудовой деятельности он посвятил переработке и улучшению качества угля. Он прервал ее лишь для защиты Родины - с 1941 по 1944 г. И.С. Благов участвовал в военных действиях в рядах действующей армии, был дважды ранен, инвалид Великой Отечественной войны. В 1944 г. по решению Государственного Комитета обороны он был отозван на восстановление угольных шахт Донбасса.

И.С. Благов прошел путь от начальника цеха Ирминской Центральной обогатительной фабрики до начальника технологического управления по обогащению и брикетированию угля Минуглепрома СССР.

При активном участии Игоря Сильвестровича велись научноисследовательские и проектно-конструкторские работы в области обогащения и переработки углей. Им создан отраслевой институт в крупнейшем угольном бассейне - Донбассе - УкрНИИуглеобогащение, руководителем которого он являлся с 1958 по 1962 г. При его активном участии Институт обогащения твердого топлива (ИОТТ) в семидесятые годы стал ведущим институтом страны в области углеобогащения.

Под руководством и при участии И.С. Благова выполнены фундаментальные и прикладные исследования, на их основе разработан полный спектр высокоэффективного оборудования для основных и вспомогательных процессов углеобогащения и прогрессивные технологии, спроектированы, построены и введены в эксплуатацию крупнейшие углеобогатительные фабрики: ЦОФ «Червоноградская», «Сибирь», «Свердловская», «Восточная», ОФ разреза «Нерюнгринский» и др. Он постоянно заботился о техническом перевооружении углеобогатительных предприятий - реконструкции действующих и строительстве новых фабрик, внедрении на них высокопроизводительных машин и аппаратов.

Игорь Сильвестрович вел большую научно-педагогическую работу: в Донбассе - в Донецком политехническом институте, в Москве - в Институте повышения квалификации Минуглепрома СССР и Московском Горном институте. Под его руководством аспиранты защитили 14 кандидатских диссертаций. Он автор 170 печатных трудов (в том числе 18 монографий) и 29 патентов. В 1984 г. ему присвоено звание профессора.

Имя Игоря Сильвестровича Благова известно широкому кругу специалистов-углеобогатителей не только в России и странах СНГ, но и за рубежом. И.С. Благов был экспертом Европейской экономической комиссии ООН от Украины, а с 1962 г. - в составе Научно-технического Совета по обогащению и переработке углей Постоянной комиссии СЭВ и в качестве члена делегации участвовал в ее заседаниях. Именно по его инициативе углеобогатители СССР начиная с 1958 г., активно участвуют в конгрессах по обогащению угля, а с V Международного конгресса (1966 г.) Игорь Сильвестрович становится постоянным членом его Международного оргкомитета от СССР, руководит Национальным оргкомитетом по проведению VIII Международного конгресса по обогащению углей в Советском Союзе.

И.С. Благов являлся членом редакционных коллегий Международного журнала «Coal Preparation», журналов «Уголь», «Уголь Украины», peферативного сборника «Обогащение и брикетирование угля», а также членом Научно-технических советов комитетов и министерств, ряда научно-исследовательских и проектно-конструкторских институтов, председателем секции «Обогащение и брикетирование угля» НТС Минуглепрома СССР.

Игорь Сильвестрович Благов принимал активное участие в общественной жизни, избирался депутатом в местные Советы народных де- 


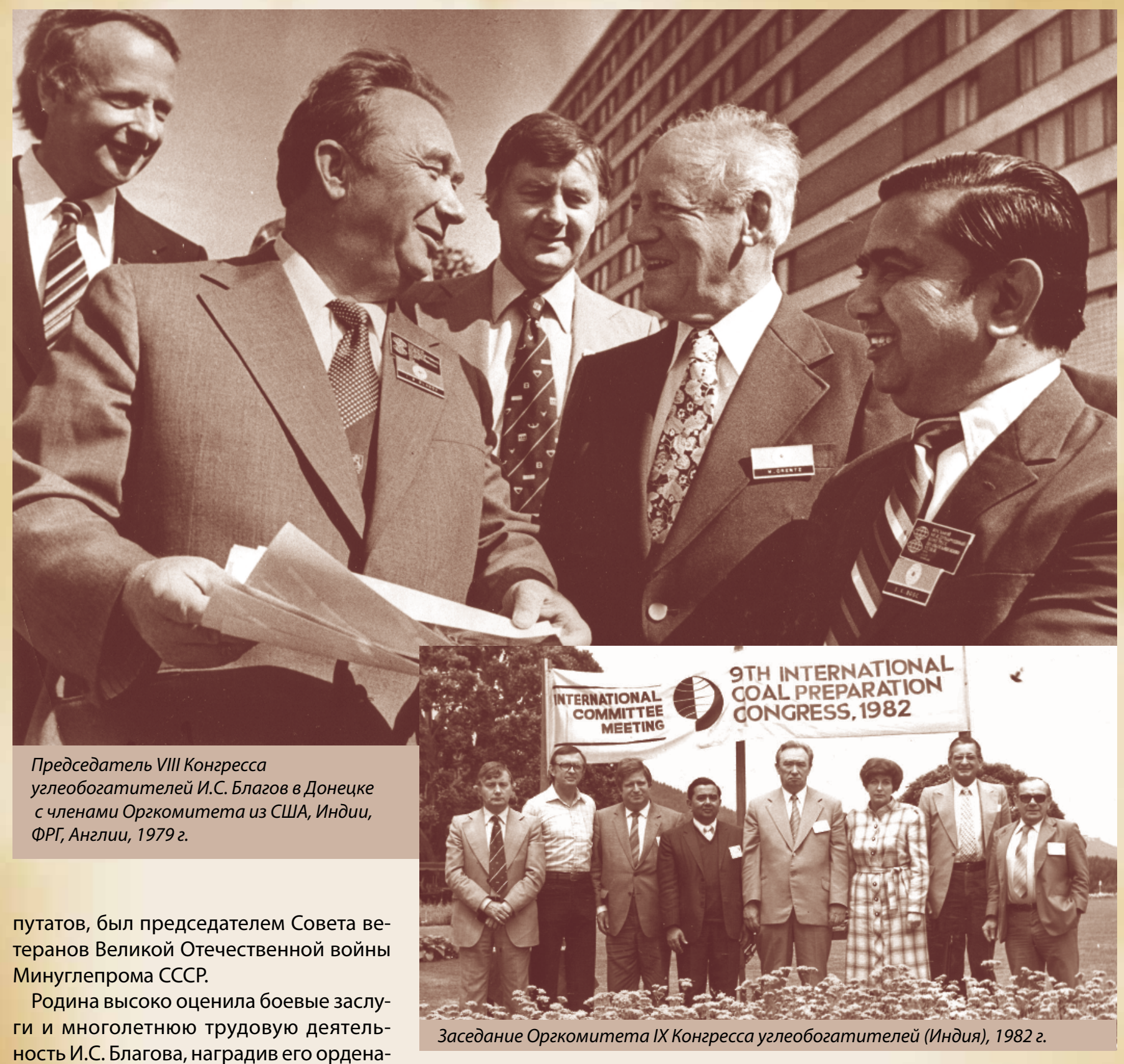
ность И.С. Благова, наградив его орденами «Трудового Красного Знамени», «Отечественной воины» | степени, «Красной Звезды», «Знак Почета» и двенадцатью медалями. Он являлся Лауреатом премии Совета Министров СССР, Заслуженным шахтером РСФСР, полным кавалером знака «Шахтерская слава», персональным пенсионером союзного значения.

Отличительные черты характера - ответственность, самоотдача, забота о людях, жизнелюбие. Игорь Сильвестрович был не только выдающимся руководителем и ученым, но и замечательным человеком. Своей доброжелательностью к окружающим, своей целеустремленностью, сочетающейся с высокой требовательностью, своей личной обязательностью он снискал глубокое уважение коллег и всех, с кем ему приходилось работать и общаться.

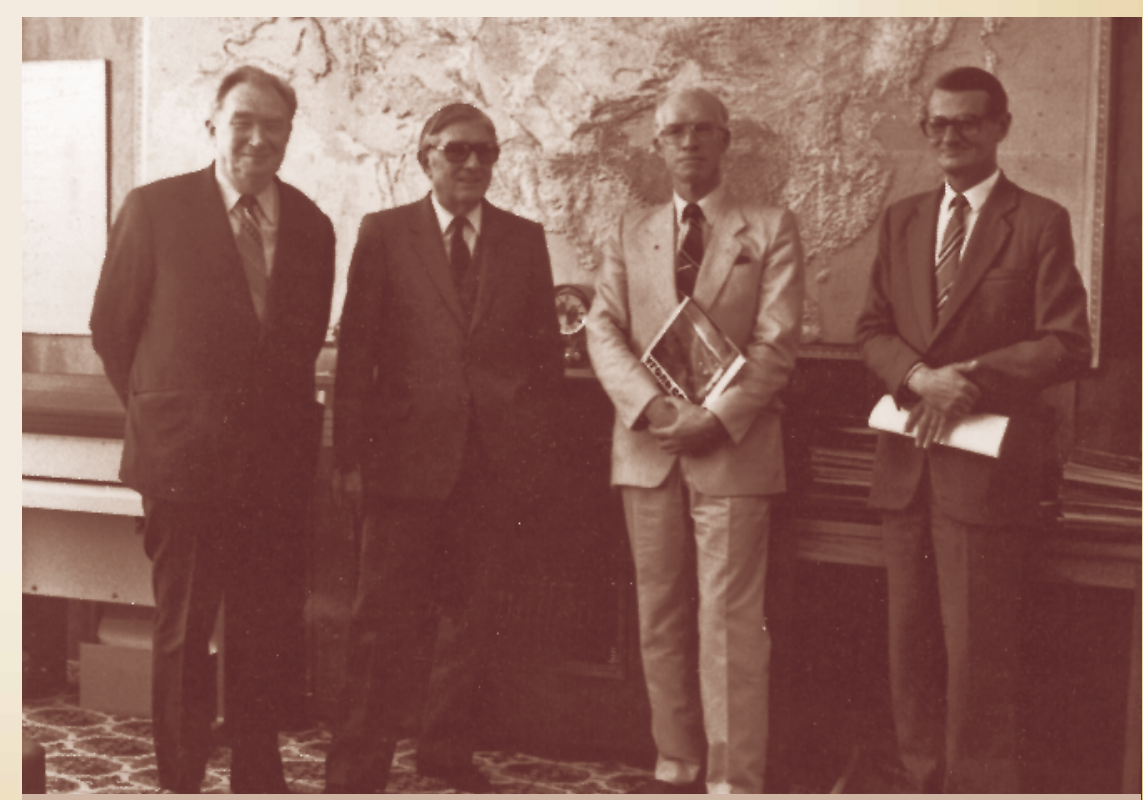

На приеме у министра угольной промышленности СССР Б.Ф. Братченко, 19852. 


\section{Организация горного производства и управление логистикой в угледобывающем секторе экономики Колумбии}

DOI: http://dx.doi.org/10.18796/0041-5790-2018-4-84-85

\section{ЗЕНЬКОВ Игорь Владимирович}

Доктор техн. наук, Заслуженный эколог $Р \Phi$, Институт вычислительных технологий СО РАН, профессор ФГБУВО «Сибирский

государственный университет науки и технологий им. академика М.Ф. Решетнёва», 660049, г. Красноярск, Россия, e-mail:zenkoviv@mail.ru

В статье представлены основные принципы организации горного производства и управление логистикой в угледобывающем секторе экономики Колумбии. Угольные разрезы являются высокомеханизированными предприятиями с высокой производительностью труда, чему способствует применениемощных экскаваторно-автомобильных комплексов на вскрышных и добычных работах.

Ключевые слова: Южная Америка, Колумбия, открытая угледобыча, организачия горного производства, управление логистикой, механизация горных работ.

\section{ВВЕДЕНИЕ}

По запасам угля Колумбия занимает первое место в Латинской Америке. Прогнозные ресурсы углей оцениваются на уровне 40 млрд т. В стране известно более 30 угольных бассейнов, угленосных зон и месторождений. Основная промышленная угленосность приурочена к позднемеловым - неогеновым отложениям Восточных и Центральных Кордильер, полуострова Гуахира. Глубина залегания продуктивных горизонтов 10-900 м [1]. В настоящее время угольные месторождения разрабатываются открытым способом в двух провинциях - Сесар и Гуахира. Центры угледобычи находятся соответственно в 540 и 740 км на север от столицы Богота и в 180 и 150 км от морских портов Карбонера Муэлье и Пийоурека [2].

\section{ПОРЯДОК ПРОИЗВОДСТВА ГОРНЫХ РАБОТ И ЛОГИСТИКА}

Угольные месторождения Колумбии обладают благоприятным горно-геологическим строением: угольные пласты по всей площади их распространения покрыты чехлом рыхлых четвертичных отложений мощностью до 40 м; суммарная мощность угольных пластов достигает 50 м; в угленосной толще пласты расположены с углами залегания в диапазоне 8-25; угленосная толща включает несколько мощных рабочих пластов. Все это позволяет разрабатывать месторождения с разноской одного рабочего борта и размещать вскрышные породы в выработанном пространстве на месте отработанных угольных пластов. Геометрия выходов угольных пластов под наносы не позволяет строить угольные разрезы со значительной протяженностью добычного фронта, как в Австралии [3], поэтому максимальная протяженность карьеров здесь не превышает 5 км.

Горно-геологическое строение месторождений обусловливает применение транспортной технологии разработки. Порядок производства горных работ следующий. Рыхлые четвертичные отложения отрабатывают одним уступом с применением мощных экскаваторно-автомобильных комплексов (ЭАК), а на разрезе Асьенда Борреро установлен драглайн с емкостью ковша $90 \mathrm{~m}^{3}$ и длиной стрелы 110 м с погрузкой вскрыши в автосамосвалы через завалочный бункер. Весь объем вскрышных пород, за исключением четвертичных отложений, подлежит рыхлению перед их экскавацией с организацией буровзрывных работ. Горно-геологические условия залегания угольных пластов позволяют организовывать массовые взрывы в объеме 0,60,7 млн м³. Вскрышные породы транспортируют на внешние отвалы либо на место отработанного угольного пласта по внутрикарьерным автодорогам.

На всех угольных разрезах выявлена главная тенденция ведения горных работ - применение мощных ЭАК, в состав которых входят экскаваторы с вместимостью ковша до $40 \mathrm{~m}^{3}$ и автосамосвалы грузоподъемностью до 360 т. На рисунке в левом кольце находится гидравлический экскаватор типа «прямая лопата» с вместимостью ковша $28 \mathrm{M}^{3}$.

В правом кольце находится карьерный канатный экскаватор типа «прямая лопата» с вместимостью ковша 40 м³. Слева и справа от этого экскаватора находятся два порожних и один груженый автосамосвалы (в верхнем секторе рисунка).

На добычных работах комплектация горнотранспортного оборудования производится по аналогии со вскрышными работами. Уголь из экскаваторных забоев транспортируют в автосамосвалах до поверхностных складов. Режим работы

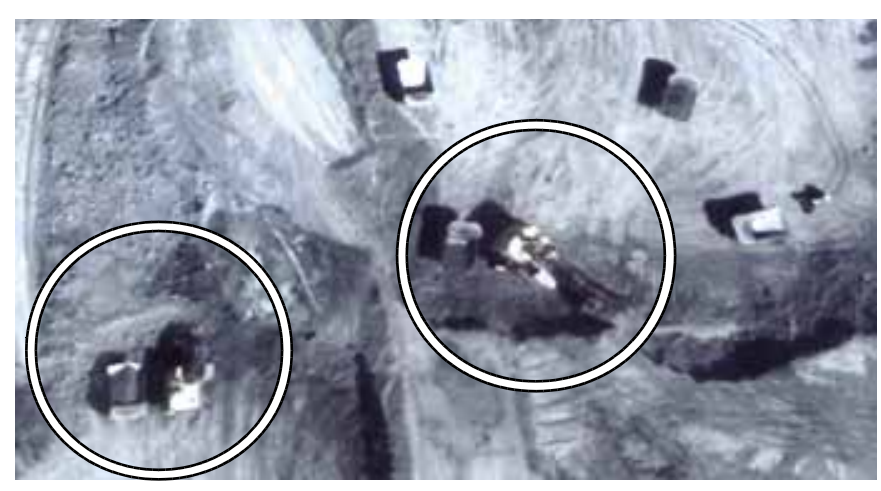

Экскаваторно-автомобильные комплексы на угольном разрезе Асьенда Борреро в Колумбии (снимок из космоса) 
угольных разрезов круглогодичный, для достижения максимального эффекта от использования основных фондов.

Логистика угольных потоков выстроена следующим образом. Весь добытый уголь складируется на площадках вблизи разрезов. По внешнему периметру складов проложен железнодорожный путь в виде петли. Движение поездов - сквозное с выходом на двухпутевую магистраль до морского порта. Поскольку перепад высот между пунктом погрузки и пунктом выгрузки составляет порядка 80 м на 180 км протяженности пути, то имеется возможность включать в один состав до 150 вагонов. В этом случае длина поезда полезным весом 12000 т составляет 2,2 км. Такой состав приводят в движение три тянущих тепловоза. В морском терминале железнодорожный путь имеет в плане форму петли, где вагоны разгружаются без переворачивания, проходя над углеприемными ямами.

\section{ЗАКЛЮЧЕНИЕ}

В настоящее время объем добычи угля, сконцентрированный на угольных разрезах с производством горных работ до глубины 80-150 м с высокой степенью механизации труда и проявлением существенногоэффекта от масштаба производства, находится, по нашей оценке, на уровне 32 млн т в год.

\section{Список литературы}

1. URL: http://www.mining-enc.ru (дата обращения: 15.03.2018).

2.URL: https://Google Earth Pro (дата обращения: 15.03.2018).

3. Зеньков И.В. Организация и экономика горного производства на угольных разрезах Восточной Австралии // Уголь. 2017. № 6. С. 66-67. URL: http://www.ugolinfo.ru/ Free/062017.pdf (дата обращения: 15.03.2018).
UDC 338.45:658.5:622.271(861) @ I.V. Zenkov, 2018

ABROAD

ISSN 0041-5790 (Print) • ISSN 2412-8333 (Online) •

Ugol' - Russian Coal Journal, 2018, № 4, pp. 84-85

Title

ORGANIZING MINING PRACTICE AND LOGISTICS MANAGEMENT IN COLOMBIA'S COAL MINING SECTOR

DOI: http://dx.doi.org/10.18796/0041-5790-2018-4-84-85

Author

Zenkov I.V.,

${ }^{1}$ Institute computational technology of Siberian Branch Russian Academy of Sciences, Krasnoyarsk, 660049, Russian Federation

${ }^{2}$ Federal State-Funded Educational Institution of Higher Professional Education (FSFEI HPE) "Reshetnev Siberian State University of Science and Technology", Krasnoyarsk, 660037, Russian Federation

\section{Authors' Information}

Zenkov I.V., Doctor of Engineering Sciences, Merited Ecologist of the Russian Federation, Professor, e-mail: zenkoviv@mail.ru

\section{Abstract}

The paper presents the main principles of organizing mining practice and logistics management in Colombia's coal mining sector. Coal strip mines are highly mechanized facilities with high labour productivity which is encouraged due to the use of powerful excavator-vehicle complexes in overburden and mining operations.

\section{Keywords}

South America, Colombia, Surface mining, Organizing mining practice, Logistics management, Mechanization of mining.

\section{References}

1. Available at: http://www.mining-enc.ru (accessed 15.03.2018)

2. Available at: https://Google Earth Pro (accessed 15.03.2018).

3.Zenkov I.V. Organizatsiya i ekonomika gornogo proizvodstva na ugol'nykh razrezakh Vostochnoy Avstralii [Mining economics and organization in the coal open-pit mines of Eastern Australia]. Ugol' - Russian Coal Journal, 2017, No. 6, pp. 60-61. Available at: http://www.ugolinfo.ru/Free/062017.pdf (accessed 15.03.2018)

\section{СУЭК помогает сделать жизнь комфортной}

В Хакасии проходит конкурс проектов «Комфортная среда обитания - 8». Организатором конкурса является Фонд социально-экономической поддержки регионов «СУЭК - РЕГИОНАМ». В рамках кон-

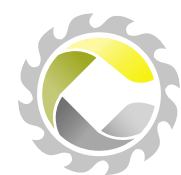

курса, который проводится ежегодно уже восемь лет, активные граждане и общественные объединения на территориях присутствия Сибирской угольной энергетической компании разрабатывают проекты по совершенствованию условий проживания.

Лучшие проекты получают финансирование от Фонда «СУЭКРЕГИОНАМ». Так, в 2017 г. поддержку СУЭК получили три проекта: «Уличные тренажеры - как альтернатива» (Бейский район, Совет молодежи Новотроицкого сельсовета), «Культурный оазис» (п. Усть-Абакан, МБУ «Районный Дом культуры «Дружба»), «Быть здоровым, жить активно...» (г. Черногорск, МБДОУ детский сад «Колосок» для слабовидящих). Годом ранее в рамках конкурса «Комфортная среда обитания» Фонд «СУЭК РЕГИОНАМ» также профинансировал три проекта в Республике Хакасия: «Территория детства» (г. Черногорск, МАДОУ детский сад «Золотая рыбка»), «Музей для всех и каждого» (р.п. Усть-Абакан, МАУК «Музей «Древние курганы Салбыкской степи»), «Здоровым быть здорово» (р.п. Усть-Абакан).

С течением лет количество участников конкурса проектов возрастает. На днях глава Усть-Абаканского района Елена Егорова обратилась к руководителям учреждений социальной сферы с предложением принять участие в конкурсах, проводимых Фондом «СУЭК РЕГИОНАМ» с целью благоустройства дворов и зданий, пополнения материальнотехнической базы. Список активных участников пополняется и в других муниципалитетах Хакасии.

«В 2018 2. мы в первый раз участвуем в конкурсе «Комфортная среда обитания», который проводит СУЭК, - говорит директор черногорского стадиона «Шахтер» Юрий Стрельченко. - Наши проекты ориентированы на то, чтобы сделать более доступными для горожан разного возраста занятия физкультурой и спортом. Особый интерес у молодежи города угольщиков вызывает возможность пробовать свои силы в единоборствах. Cтоит отметить, что спортивные проекты в Черногорске СУЭК поддерживает систематически, поэтому, конечно же, есть смысл активно участвовать в конкурсах, которые организует компания».

Только в 2017 г. на конкурс «Комфортная среда обитания» в регионах присутствия СУЭК - в Кемеровской области, Забайкальском, Красноярском, Приморском, Хабаровском краях, Республиках Бурятия и Хакасия - поступило 244 проекта в пяти номинациях: «Уютный двор, уютный дом», «Красота вокруг нас», «Чистый город - здоровое будущее», «Территория здоровья» и «Познаем Россию». Фонд «СУЭК РЕГИОНАМ» безвозмездно выделил денежные средства на реализацию 24 проектов. 


\section{(к 70-летию со дня рождения)}

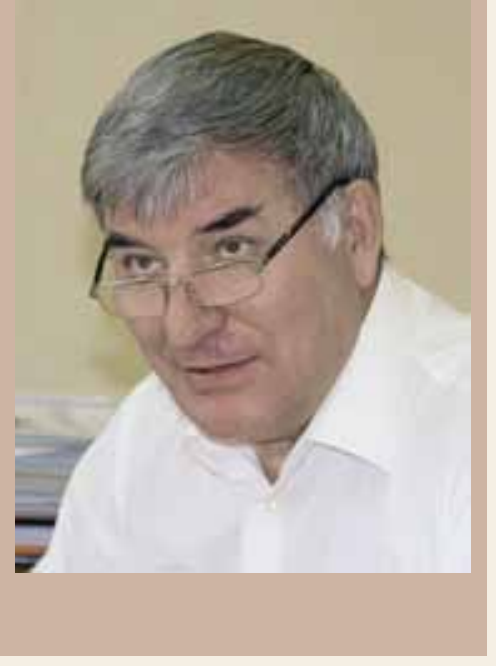

25 апреля 2018 г. исполняется 70 лет известному организатору и исследователю теории и практики повышения безопасности и эффективности горного производства, доктору технических наук, профессору, руководителю отраслевого института НИИОГР с 1985 г. Владимиру Алексеевичу Галкину.

Владимир Алексеевич родился в г. Магнитогорск в семье горных инженеров А.М. Галкина и Л.П. Сологуб. После окончания в 1971 г. Магнитогорского горнометаллургического института им. Г.И. Носова он трудился на Сорском молибденовом комбинате, пройдя путь от сменного горного мастера до начальника горного участка, затем начальника участка новой техники. Острая потребность В.А. Галкина в совершенствовании производства выразилась в систематической работе по рационализации и улучшению организации труда, повышению его эффективности и безопасности.

Постоянное стремление Владимира Алексеевича к развитию своего профессионализма привело к необходимости подготовки кандидатской диссертации, которая была успешно защищена в ИГД МЧМ СССР (г. Свердловск) в 1979 г.

В 1980 г. В.А. Галкин возглавил кафедру «Организация горных работ и промышленный транспорт» Магнитогорского горно-металлургического института. Он наладил процесс взаимовыгодного сотрудничества между кафедрой и рядом горнодобывающих предприятий цветной и черной металлургии: ГМК «Печенганикель» (г. Заполярный), Сорский МК (г. Сорск), БМСК (г. Сибай), Орловский ГОК (пгт. Новоорловск), ТВМК (г. Тырныауз), Учалинский ГОК (г. Учалы), ММК (г. Магнитогорск). За период 19801985 гг. на кафедре было выполнено более 100 исследовательских дипломных работ, результаты которых не только получили признание на областных, республиканских и союзных конкурсах, но главное - значительная их часть вызвала живой интерес у руководителей производства и была реализована. Многие студенты, принимавшие активное участие в проводимых кафедрой хоздоговорных работах, в дальнейшем стали кандидатами и докторами наук, и нынешнее руководство, «докторское ядро» преподавателей кафедры, а также руководство «Института горных технологий и транспорта» МГТУ в основном сформированы именно из этих студентов.

С 1985 г. в жизни Владимира Алексеевича начался следующий период, связанный с реформированием отраслевого института угольной промышленности (НИИОГР) в жизнеспособную рыночную структуру, удовлетворяющую нарастающие потребности горнодобывающих предприятий и компаний в сфере обеспечения безопасности труда и эффективности производства. С участием крупных ученых по профилю деятельности института, а также с руководителями и специалистами ведущих горнодобывающих предприятий в 1985-1990 гг. была разработана и реализуется по сей день стратегия развития института, нацеленная на обеспечение соответствия его деятельности динамике внешней среды, потребностям партнеров, клиентов и интересам работников института.
Защита Владимиром Алексеевичем в 1988 г. докторской диссертации заложила основы для развития научной школы института. Научно-методическая квалификация сотрудников была объявлена главным фактором повышения качества работы и ее результатов. За 1985-2017 гг. в НИИОГР подготовлено около 100 диссертационных работ, в том числе 30 докторских. Более половины из них посвящены решению проблем организации безопасного и эффективного производства - основному направлению сформированной научной школы. Это дало мощный импульс развитию нематериальных активов института, укрепило связи с научной общественностью, создало хорошую базу для взаимовыгодного сотрудничества с заинтересованными в устойчивом развитии горнодобывающими предприятиями и компаниями.

К разработке и реализации эффективных решений проблем обеспечения жизнеспособности горнодобывающих предприятий и компаний в переходный период и период становления новых экономических отношений в России было привлечено более 15 тыс. работников этих предприятий.

В настоящее время НИИОГР ежегодно посещают более 300 руководителей и специалистов горнодобывающих предприятий для подготовки себя к работе в условиях новых, гораздо более высоких, требований к безопасности и эффективности производства. С этой целью совместно с генеральным партнером - АО «СУЭК» в НИИОГР развивается деятельность центра самоподготовки руководящего персонала горнодобывающих предприятий. Многолетняя дружба и партнерство (более 30 лет) связывают Владимира Алексеевича и редакцию журнала «Уголь». Благодаря этому сотрудничеству появились новые актуальные рубрики, налажено взаимодействие с угольными компаниями, в первую очередь с АО «СУЭК», многие работники этой компании и НИИОГР стали постоянными авторами и читателями журнала.

Главный принцип в деятельности юбиляра: «Развивая людей, развивать дело; развивая дело, развивать людей». В канун своего 70-летия Владимир Алексеевич Галкин, как всегда, бодр, целеустремлен, динамично развивается сам и увлекает в этот процесс сотрудников института и предприятий-партнеров.

Коллектив НИИОГР, партнеры, научная общественность, работники горной промышленности, редакционная коллегия и редакция журнала «Уголь» сердечно поздравляют Владимира Алексеевича Галкина с юбилеем и желают активного долголетия! 


\section{ЭКГАРДТ Виктор Иванович}

\section{(к 70-летию со дня рождения)}

1 мая 2018 2. исполняется 70 лет горному инженеру, доктору технических наук, действительному члену Академии горных наук, членукорреспонденту Российской академии естественных наук, Почетному шахтеру Российской Федерации, Почетному работнику угольной промышленности, Заслуженному работнику Республики Коми Виктору Ивановичу Экгардту.

В.И. Экгардт родился в 1948 г. в Заполярной Воркуте Коми АССР, в семье репрессированных российских немцев. Первую горняцкую профессию электрослесаря подземного получил в старших классах средней политехнической школы, после окончания которой, в 1966 г. начал трудовой путь в Шахтоуправлении № 2 (ШУ-2) комбината «Воркутуголь». Окончив в 1972 г. вечернее отделение Воркутинского филиала Ленинградского горного института, он продолжил работу на шахте в должности помощника начальника участка вентиляции и техники безопасности.

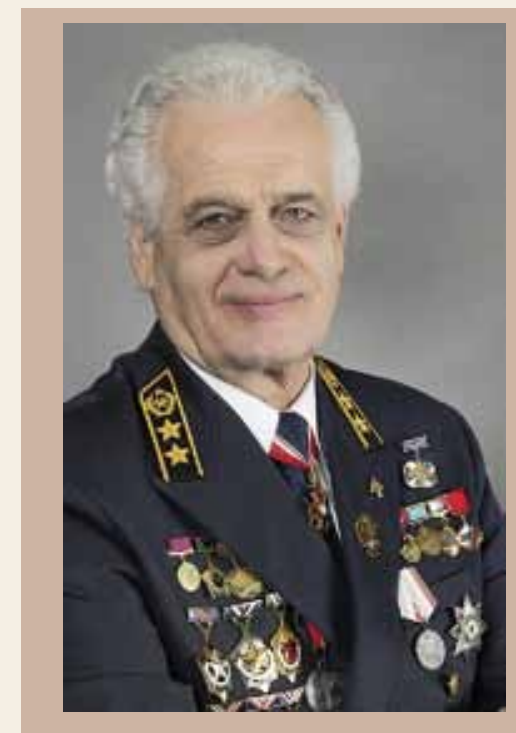

Виктор Иванович принимал активное участие в реконструкции ШУ-2 с объединением трех шахт военного периода постройки в единый производственный комплекс с общей системой проветривания. После реконструкции ШУ-2 преобразовано в шахту «Аяч-Яга», которая становится базовой моделью по внедрению новейших разработок в области расчета шахтных вентиляционных систем и составления планов ликвидации аварий с применением ЭВМ. Полученный в этот период научный и практический опыт во многом предопределил будущее молодого горного инженера. В 1981 г., будучи уже опытным специалистом в вопросах проветривания и дегазации шахт, организации охраны труда и ТБ он назначается заместителем технического директора ПО «Воркутауголь».

В 1989 г. по просьбе трудового коллектива Виктор Иванович назначается директором шахты «Аяч-Яга». Под его руководством и с личным участием, в труднейшие годы развала промышленности, экономики страны и угольной отрасли на шахте начинается очередная реконструкция, в ходе которой производится строительство нового ствола с рудничным двором, реконструируется поверхностный комплекс, вскрываются и подготавливаются новые горизонты. Модернизация производства позволила увеличить нагрузку на очистные забои, повысить производительность труда, поднять производственную мощность шахты, создать условия стабильного выполнения и перевыполнения производственных планов.

В 1995 г. В.И. Экгардт избирается председателем Совета директоров ПО «Воркутауголь», а в 1997 г. генеральным директором ОАО «Воркутауголь». Под его руководством активно продолжается реструктуризация угольного производства шахт Воркуты, неуклонно растут производственно-технические и экономические показатели. Практически при полном отсутствии государственной поддержки ОАО «Воркутауголь» вышло на безубыточную работу и было номинировано на главную всероссийскую премию «Российский Национальный Олимп» за высокие достижения в социально-экономической сфере России.

В 1997 г. Виктор Иванович по совместительству возглавил кафедру «Разработка пластовых месторождений полезных ископаемых» Воркутинского горного института, филиала Санкт-Петербургского горного университета и в течение 17 лет ведет активную преподавательскую работу на вечернем и заочном отделениях, совмещая ее с научно-практической деятельностью в содружестве с преподавателями учебного института и сотрудниками отраслевого научно-исследовательского и проектного института «Печорниипроект».

В 1997-2007 гг. В.И. Экгардт избирался депутатом Государственного Совета Республики Коми трех созывов. В 2006-2010 гг. работал советником главы Республики Коми по работе с федеральными структурами. В настоящее время, проживая в Москве, Виктор Иванович ведет активную общественную работу, являясь заместителем председателя Правления РОО «Землячество Коми». С 2009 г., являясь профессором Санкт-Петербургского горного университета, он входит в состав диссертационного совета университета и активно участвует в его работе.

За большой вклад в развитие Печорского угольного бассейна Виктор Иванович Экгардт отмечен правительственными и ведомственными наградами. Он полный кавалер знаков «Шахтерская слава», «Трудовая слава» и «Горняцкая слава», награжден Золотым знаком «Горняк России», Почетным знаком Российского союза промышленников и предпринимателей, знаком «За заслуги перед Республикой Коми», Бронзовой медалью ВДНХ СССР, Орденом «Святого Станислава» в честь 300-летия Горного дела в России, почетными грамотами Государственной Думы РФ, Государственного Совета Республики Коми, Верховного Совета Коми АССР. В 2005 г. удостоен звания «Лауреат Премии Правительства Российской Федерации» в области науки и техники.

\section{Коллеги по работе, друзья и соратники, редколлегия и редакция журнала «Уголь» от всей души поздравляют Виктора Ивановича Экгардта с юбилеем и желают ему здоровья, долгих плодотворных лет, творческих успехов,




\section{Требования к рукописям, направляемым в журнал «Уголь»}

1. Статьи, направляемые в журнал «Уголь», должны освещать наиболее актуальные вопросы технического, экономического и социального развития предприятий угольной промышленности. Должны быть освещены проблемы, даны конкретные выводы и предложения.

2. Все статьи научного, научно-технического, экономического и социально-экономического характера рецензируются. К статье научного, научно-технического, экономического и социально-экономического профиля должен быть приложен отзыв специалиста - доктора, кандидата наук.

3. Максимальный объем статьи - не более 10 страниц, включая 3-4 рисунка (фото), аннотацию и библиографический список.

4. Материал должен быть изложен кратко, без повторений данных таблиц и рисунков в тексте; на литературу, таблицы и рисунки следует давать ссылки в тексте. Формулы - только основные, без промежуточных выкладок.

5. Статья должна иметь не более 5 авторов.

6. Статья в обязательном порядке должна иметь (в том числе и на английском языке):

- контактные данные по каждому автору:указываются полностью ФИО, место работы, должность, ученые степени и звания (при наличии), почтовый адрес, телефон, е-mail, по желанию прилагаются портреты авторов;

- peферат (аннотацию) - 10-15 строк (100250 слов). В соответствии с требованиями международных баз данных реферат должен достаточно полно раскрывать содержание статьи (кратко о чем статья, тезисно суть статьи, основные выводы);

- ключевые слова - 8-10 наименований по тематике статьи;

- библиографический список (список литературы) - не менее 12 источников (!).

7. Статья должна иметь библиографический список, состоящий из не менее 12 позиций, с обязательным включением 5-6 источников позднее 2010 г. и 4-5 ссылок на зарубежные публикации последних 5 лет (!) (ссылки на иностранные патенты, авторские свидетельства, нормативно-правовые документы не входят в число зарубежных публикаций). Включение в список более 2-3 собственных работ не допускается (!).

Библиографический список должен соответствовать требованиям ГОСТ 7,1-2003 (и его более поздней версии 2008 г.) и содержать следующие сведения:

- при ссылке на журнальную статью - фамилию и инициалы автора, название статьи, полное название журнала, год издания, номер, страницы начала и конца статьи;

- при ссылке на книгу - фамилию и инициалы автора, название, место издания, издательство (для иностранного источника достаточно указать город), год издания, общее число страниц в книге;

- при ссылке на статью в сборнике - название сборника, номер выпуска (или тома), место издания, изда- тельство (или издающая организация), страницы начала и конца статьи;

- для интернет-ссылок - название ресурса и публикации, режим доступа.

Номер литературной ссылки дается в квадратных скобках в соответствующем месте текста.

При использовании электронных ресурсов необходимо ссылаться на первоисточник и указывать дату обращения.

При составлении библиографических списков авторам рекомендуется использовать надежные верифицируемые источники и избегать ссылок на публичные ресурсы, информация из которых не может иметь авторитетного подтверждения (например, Википедия).

Все библиографические сведения должны быть тщательно проверены. Не допускаются ссылки, которые не могут быть прослежены (найдены) читателями, например презентации, отчеты о НИР, НИОКР, ПИР и пр., а также на неопубликованные работы.

8. Необходимо четко структурировать текст статьи по следующим разделам:

- введение, где кратко выполнен обзор проблемы, обоснована актуальность работы, приведена ее цель;

- основной раздел, включающий результаты выполненной работы, с кратким описанием или упоминанием (общепринятых или опубликованных в известных изданиях) методик и/или методов проведения экспериментальных или опытных работ;

- заключение, в котором сделаны выводы и даны рекомендации по практическому использованию результатов работы.

9. Перед отправкой статьи в редакцию авторам необходимо с помощью специальной программы (например, www.text.ru) проверить текст и удостовериться в отсутствии заимствований из других публикаций, не подтвержденных библиографическими ссылками.

10. Рисунки к статье должны быть четкими; не следует перегружать их второстепенными данными. Все рисунки и фото должны быть с подрисуночными подписями.

11. Статья должна быть подписана всеми авторами (прилагается скан страницы с подписями авторов).

12. Материалы по статье следует направлять в редакцию по е-mail: ugol1925@mail.ru.

13. Текст статьи, рисунки, схемы, диаграммы должны быть записаны в Word 97-2003. Кроме того, все рисунки и фото должны быть представлены в виде графических файлов JPEG (с разрешением 300 dpi).

14. Несоответствие статьи вышеописанным требованиям может послужить поводом для отказа в публикации. Поступившие в редакцию материалы авторам не возвращаются.

См. требования также на сайте журнала «Уголь» в разделе Требования http://www.ugolinfo.ru/trebovania.html 


\section{Ощутите прогресс}

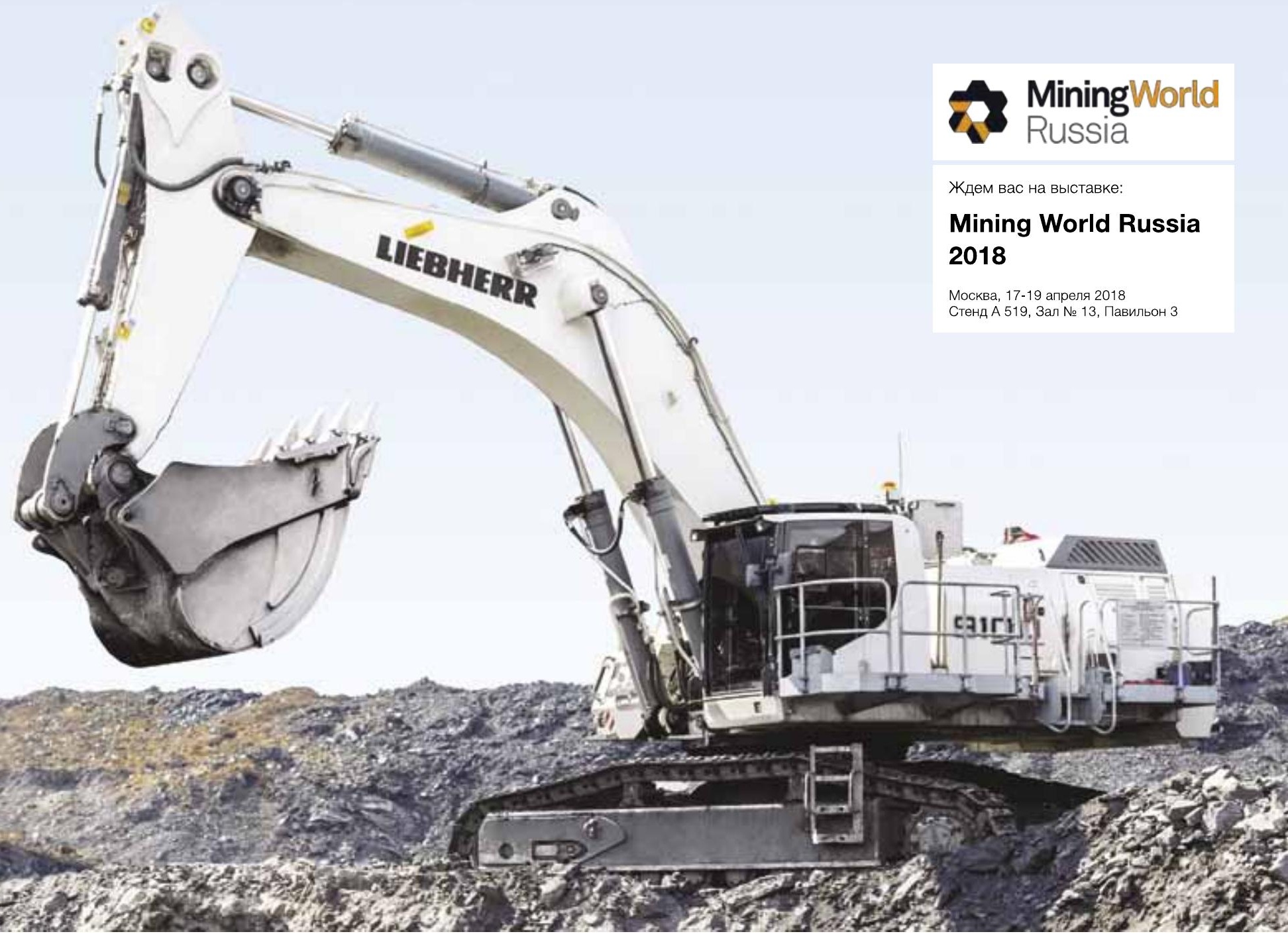

\section{Liebherr R 9100 \\ технологии на службе Вашего успеха}

- Энергичные рабочие циклы: уникальная система управления Liebherr для оптимального распределения мощности

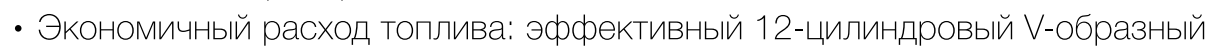
дизельный двигатель Liebherr

- Высокая производительность: усиленные ковши собственной разработки Liebherr

- Удобное обслуживание: централизованное расположение сервисных точек

- Комфорт: эргономичная кабина, оснащённая по последнему слову техники 


\section{КОСМИЧЕСКИЕ ТЕХНОЛОГИИ В УГОЛЬНОЙ ОТРАСЛИ}

\section{МНОГОФУНКЦИОНАЛЬНАЯ СИСТЕМА \\ БЕЗОПАСНОСТИ «УМНАЯ ШАХТА» ${ }^{\circledR}$ - ГОРНАСС}

1 Мониторинг параметров работы шахты в режиме реального времени, включая:

- сканирующий (динамический) газовый контроль;

- позиционирование персонала и шахтного транспорта.

2 Аварийное оповещение персонала с автоматическим (контроль доставки) и ручным (контроль осознания) подтверждением получения сигнала.

3 Мобильная связь с использованием смартфона на платформе Android c возможностью проведения фото- и видеосъемки в шахте, в том числе в тепловизионном режиме.

4 Функционирование благодаря применению беспроводных технологий, после воздействия ударно-взрывной волны.

5 Передача данных в горных выработках с фантастической скоростью.

Система соответствует требованиям раздела 6 национального стандарта РФ ГОСТ P 55154-2012 «Оборудование горно-шахтное. Системы безопасности угольных шахт многофункциональные. Общие технические требования». 